María Alejandra Gómez Pivel

\title{
Reconstrução da hidrografia superficial do Atlântico Sul Ocidental desde o Último Máximo Glacial a partir do estudo de foraminíferos planctônicos
}

Tese apresentada ao Instituto Oceanográfico da Universidade de São Paulo, como parte dos requisitos para obtenção do título de Doutor em Ciências, área de Oceanografia Química e Geológica

Orientador: Prof. Dr. Felipe A. L. Toledo

São Paulo

2009 
Universidade de São Paulo

Instituto Oceanográfico

\section{Reconstrução da hidrografia superficial do Atlântico Sul Ocidental desde o Último Máximo Glacial a partir do estudo de foraminíferos planctônicos}

Tese apresentada ao Instituto Oceanográfico da Universidade de São Paulo, como parte dos requisitos para obtenção do título de Doutor em Ciências, Programa de Oceanografia Química e Geológica

Julgada em por

Prof(a). Dr(a).

Conceito

Prof(a). Dr(a).

Conceito

Prof(a). Dr(a).

Conceito

Prof(a). Dr(a).

Conceito

Prof(a). Dr(a).

Conceito 
Lista de Figuras

Pág.

Tista de Figuras

Lista de Tabelas

iv

Resumo

$\mathrm{x}$

xi

Abstract

xii

Nota sobre nomenclatura

xiii

Lista de siglas e abreviações

xiv

Agradecimentos

$\mathrm{XV}$

1. INTRODUÇÃO

2. ÁREA DE ESTUDO 5

2.1. CONTEXTO GEOMORFOLÓGICO E SEDIMENTAR 5

2.2. CLIMA

2.2.1. A precipitação e o Sistema de Monção da América do Sul 9

2.3. OCEANOGRAFIA 11

2.3.1. Propriedades das águas superficiais $\quad 11$

$\begin{array}{ll}\text { 2.3.2. Massas d'água e circulação } & 15\end{array}$

$\begin{array}{ll}\text { 2.3.3. Variabilidade sazonal e interanual } & 18\end{array}$

$\begin{array}{ll}\text { 2.3.4. Produtividade } & 19\end{array}$

3. CONTEXTO PALEOCLIMÁTICO E PALEOCEANOGRÁFICO DESDE O ÚLTIMO MÁXIMO GLACIAL DE ACORDO COM ESTUDOS PRETÉRITOS 23

3.1. O ÚLTIMO MÁXIMO GLACIAL 23

$\begin{array}{ll}\text { 3.1.1. Os oceanos no UMG } & 27\end{array}$

3.1.1.1. A variação da TSM: do CLIMAP ao MARGO 29

3.2. A DEGLACIAÇÃO 33

3.2.1. Início da deglaciação: aquecimento no Sul e armadas de icebergs no 34

\begin{tabular}{ll} 
Atlântico Norte & 34 \\
\hline
\end{tabular}

3.2.2. Resfriamento no Sul e aquecimento no Norte 36

3.2.3. Breve retorno às condições glaciais - o Younger Dryas 37

3.3. O HOLOCENO 38

3.3.1. Forçantes de variabilidade climática no Holoceno $\quad 40$

4. MATERIAL E MÉTODOS

4.1. AMOSTRAGEM E PROCESSAMENTO INICIAL DAS AMOSTRAS 45 
4.3. ESTIMATIVAS DE PALEOTEMPERATURA 49

4.3.1. As Redes Neurais Artificiais $\quad 50$

4.4. ESTIMATIVAS DE PALEOSSALINIDADE 53

4.4.1. Análises isotópicas $\quad 53$

4.4.2. Cálculos $\quad 54$

4.5. ESTIMATIVAS DE PALEOPRODUTIVIDADE 56

4.6. TEOR DE $\mathrm{CaCO}_{3}$ E FLUORESCÊNCIA DE RAIOS X NA FRAÇÃO FINA 56

4.7. REANÁLISE DO TESTEMUNHO SAN76 57

5. RESULTADOS 59

5.1. TESTEMUNHO KF02 59

5.1.1. Descrição do testemunho $\quad 59$

$\begin{array}{ll}\text { 5.1.2. Modelo de idade } & 61\end{array}$

5.1.2.1. Taxas de sedimentação $\quad 62$

5.1.3. Censos de fauna 64

5.1.4. Isótopos estáveis $\quad 73$

5.1.5. Estimativas de paleotemperatura $\quad 75$

$\begin{array}{ll}\text { 5.1.6. Estimativas de paleossalinidade } & 77\end{array}$

$\begin{array}{ll}\text { 5.1.7. Estimativas de paleoprodutividade } & 79\end{array}$

5.1.8. Análises de Teor de Carbonato e Fluorescência de Raios X. 81

5.2. REANÁLISE DO TESTEMUNHO SAN76 82

5.2.1. Modelo de idade $\quad 82$

5.2.2. Estimativas de paleotemperatura $\quad 85$

$\begin{array}{ll}\text { 5.2.3. Estimativas de paleossalinidade } & 86\end{array}$

5.3. RESULTADOS COMBINADOS DE KF02 E SAN76 87

6. DISCUSSÃO 98

6.1. SOBRE A PALEOTEMPERATURA 101

6.1.1. Paleotemperaturas semelhantes para diferentes composições de fauna $\quad 101$

6.1.2. Comparação das estimativas das técnicas SIMMAX e RNAs 102

6.1.3. Variações de paleotemperatura 104

6.2. SOBRE A PALEOSSALINIDADE 108

6.2.1. As limitações do método residual de isótopos de oxigênio 109

$\begin{array}{ll}\text { 6.2.2. Variações de paleossalinidade } & 111\end{array}$

$\begin{array}{ll}\text { 6.3. SOBRE A PALEOPRODUTIVIDADE } & 115\end{array}$ 
6.3.1. Sobre os indicadores utilizados 116

$\begin{array}{ll}\text { 6.3.2. Variações de paleoprodutividade } & 121\end{array}$

$\begin{array}{ll}\text { 6.3.2.1. Testemunho KF02 } & 121\end{array}$

$\begin{array}{ll}\text { 6.3.2.2. Testemunho SAN76 } & 125\end{array}$

6.4. AS VARIAÇÕES DE PALEOTEMPERATURA E PALEOSSALINIDADE NO CONTEXTO REGIONAL E GLOBAL

126

6.4.1. Variações do SMAS 133

7. CONCLUSÕES 136

8. REFERÊNCIAS BIBLIOGRÁFICAS 138

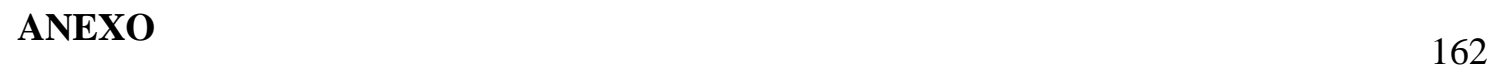


Fig. 2.1. Localização dos testemunhos analisados. Mapa construído a partir de dados de linha de costa e rios do Coastline Extractor do NGDC/NOAA e dados batimétricos de Smith e Sandwell, 1997. As isóbatas desenhadas correspondem às profundidades iguais a 100, 200, 500, 1000, 2000 e $3000 \mathrm{~m}$. . . . . . . . . . . . . . . . .

Fig. 2.2. Mudança sazonal da localização da ZCIT. A linha pontilhada em vermelho marca a posição média da ZCIT em janeiro (à esquerda) e julho (à direita). A escala de cores representa a pressão ao nível do mar. Fonte: NCEP/NCAR Reanalysis Project, 1959-1997 Climatologies, Departamento de Geografia da Universidade do Oregon, EUA. . . . . . . . . . . . . . . . . . . . . . . .

Fig. 2.3. Velocidade média do vento em superfície (vetores) e taxas de precipitação (escala de cores) segundo estimativas de radiômetro de microondas a bordo do satélite Tropical Rainfall Measuring Mission (TRMM) para (a) Janeiro e (b) Julho (Fonte: NASA Earth Observatory). . . . . . . . . . . . . . . . . . . . . . . . .

Fig. 2.4. Vetores de vento em $925 \mathrm{hPa}$, linhas de vento em $200 \mathrm{hPa}$ e estimativas de precipitação baseadas em dados satelitais e estações meteorológicas (ver escala de cores) segundo dados de reanálise do NCEP/NCAR de 1979 a 1997 para os meses de dezembro a fevereiro. A linha grossa pontilhada marca a o eixo aproximado da ZCAS. As letras "A" e "H" marcam respectivamente a localização da Alta da Bolívia e da Alta Subtropical do Atlântico Sul. (Fonte: CLIVAR/VAMOS). . . . . . . . . .

Fig. 2.5. Variação sazonal da TSM $\left({ }^{\circ} \mathrm{C}\right)$ de acordo com o World Ocean Atlas 2005 (WOA05, Locarnini et al., 2006): (a) janeiro a março, (b) abril a junho, (c) julho a setembro e (d) outubro a dezembro. Contornos a cada $2^{\circ} \mathrm{C}$.

Fig. 2.6. Variação sazonal da SSM de acordo com o WOA05 (Antonov, 2006): (a) janeiro a março, (b) abril a junho, (c) julho a setembro e (d) outubro a dezembro. Contornos a cada duas unidades. . . . . . . . . . . . . . . . . . . . . . .

Fig. 2.7. Média anual da SSM no oceano moderno segundo dados do WOA05 (Antonov, 2006) . . . . . . . . . . . . . . . . . . . . . . . . . .

Fig. 2.8. Esquema geral de circulação superficial do Atlântico Sul, de acordo com Peterson e Stramma (1991) . . . . . . . . . . . . . . . . . . . . . . . . .

Fig. 2.9. Diagrama T-S espalhado característico da região de estudo. Dados coletados no verão de 2002 entre Cabo Frio e São Sebastião. Modificado de Sorano (2006). .

Fig. 2.10. Imagem de AVHRR mostrando a ressurgência costeira de Cabo Frio e o meandramento da CB (Mahiques et al., 2005) . . . . . . . . . . . . . . . . .

Fig. 2.11. Esquema do efeito combinado da ressurgência costeira associada à ação dos ventos de $\mathrm{NE}$ e a ressurgência induzida pela ação de meandros da $\mathrm{CB}$ ( $\mathrm{AC}=$ Água Costeira; AT = Água Tropical e ACAS= Água Central do Atlântico Sul) (Campos et al., 2000) . . . . . . . . . . . . . . . . . . . . . . . . . . . . 
Fig. 2.12. Estimativa de TSM de acordo com imagem de AVHRR/NOAA durante julho de 1993. Modificado de Campos et al. (1999). A cor azul indica a advecção de águas frias provenientes de sudoeste. . . . . . . . . . . . . . . . . . .

Fig. 3.1. Variação da concentração e forçante radiativa do dióxido de carbono (esquerda) e metano (direita) para os últimos 20 mil anos de acordo com dados de testemunhos de gelo da Antártida e Groenlândia e, mais recentemente, medições atmosféricas (Jansen et al., 2007) (HN = Hemisfério Norte, HS = Hemisfério Sul). . .

Fig. 3.2. Razão ${ }^{231} \mathrm{~Pa} /{ }^{230} \mathrm{Th}$ em amostras de sedimentos do UMG (linha azul) e Holoceno (linha laranja) de diferentes profundidades do Atlântico Norte de acordo com Gherardi et al. (2009). A escala da razão ${ }^{231} \mathrm{~Pa} /{ }^{230} \mathrm{Th}$ está invertida de maneira a mostrar uma MOC mais intensa do lado direito da figura. A linha vertical pontilhada indica a taxa de produção. Localização dos testemunhos: DAPC2- $58^{\circ} 58^{\prime} \mathrm{N}, 09^{\circ} 36^{\prime} \mathrm{W}$, $1709 \mathrm{~m}$ de profundidade; MD95-2037: $37^{\circ} 05^{\prime} \mathrm{N}, 32^{\circ} 01^{\prime} \mathrm{W}, 2150 \mathrm{~m}$ de profundidade; SU81-18- $37^{\circ} 46^{\prime} \mathrm{N}, 10^{\circ} 11^{\prime} \mathrm{W}, 3135 \mathrm{~m}$ de profundidade; SU90-44- $50^{\circ} 01^{\prime} \mathrm{N}, 17^{\circ} 06^{\prime} \mathrm{W}$, $4279 \mathrm{~m}$ de profundidade e OCE326-GGC5- $33^{\circ} 42^{\prime} \mathrm{N}, 57^{\circ} 35^{\prime} \mathrm{W}, 4550 \mathrm{~m}$ de profundidade. . . . . . . . . . . . . . . . . . . . . . . . . . . .

Fig. 3.3. Mapas de anomalias de TSM para o UMG computadas a partir da comparação das estimativas do Projeto MARGO (2009) com os valores modernos de TSM do WOA98. Estimativas para o inverno austral (topo), verão austral (meio) e média anual (figura inferior). Os símbolos brancos indicam a localização dos dados proxies utilizados na reconstrução. . . . . . . . . . . . . . . . . . . . . .

Fig. 3.4. Estimativas de variações no volume de gelo global e correspondentes variações do nível do mar para os últimos 20 mil anos de acordo com Lambeck et al. (2002). As setas indicam o rápido pulso de degelo MWP-1a e a estabilização durante o YD. . . . . . . . . . . . . . . . . . .

Fig. 3.5. Razão ${ }^{231} \mathrm{~Pa} /{ }^{230} \mathrm{Th}$ em amostras de sedimentos de períodos correspondentes ao H1 (linha azul), BA (linha vermelha) e YD (azul claro pontilhado) de diferentes profundidades do Atlântico Norte (Gherardi et al., 2009). As estimativas para o UMG e Holoceno da Fig. 3.2. foram desenhadas em linhas claras pontilhadas párea comparação. A escala da razão ${ }^{231} \mathrm{~Pa} /{ }^{230} \mathrm{Th}$ está invertida de maneira a mostrar uma MOC mais intensa do lado direito da figura. A linha vertical pontilhada indica a taxa de produção. Os testemunhos são os mesmos da Fig. 3.2. . . . . . . . . . . . .

Fig. 3.6. Síntese espacial das mudanças climáticas globais ocorridas no período préindustrial, quando comparado ao Holoceno Médio (6 mil anos AP), de acordo com Wanner et al. (2008) . . . . . . . . . . . . . . . . . . . . . . . . . . .

Fig. 3.7. A posição dos equinócios e solstícios muda lentamente ao redor da órbita elíptica da Terra, levando um tempo aproximado de 22 mil anos para completar um ciclo. Enquanto hoje a Terra se encontra mais próxima do sol durante o solstício de verão austral, há 11 mil anos a situação era a oposta (Imbrie e Imbrie, 1979). . .

Fig. 4.1. Distribuição das amostras utilizadas por tipo de análise ao longo do testemunho KF02. O X vermelho indica a seção de testemunho não disponibilizada para análise. . . . . . . . . . . . . . . . . . . . . . . . . 
Fig. 4.2. Fluxograma resumido das etapas realizadas para obtenção das estimativas desejadas. . . . . . . . . . . . . . . . . . . . . . . . . . . . . . . .

Fig. 4.3. Arquitetura geral de uma rede neural de retropropagação com três camadas. Em cada neurônio das camadas escondidas e da camada de saída são somados os sinais recebidos da camada prévia (p) multiplicados pelos seus respectivos pesos sinápticos (w). A isto é somado um bias (b) ou perturbação com o efeito de aumentar ou diminuir a entrada. O somatório final é filtrado com uma função de transferência (por ex. linear ou sigmoidal) para produzir a atividade (a) do neurônio a qual é enviada à camada subseqüente ou, no caso da última camada, representa diretamente a saída. Adaptado de Malmgren e Nordlund (1997) e Kucera (2003). . . . . . . . . . . . . . . .

Fig. 5.1. Descrição (a) e fotos (b) do testemunho KF02. Legenda: LL = Lama (argila siltosa) levemente carbonática de cor cinza olivácea gradando para LR = lama cinza esverdeada rica em carbonato. Cores de acordo com a classificação de cores de Munsell. Biozonas de acordo com Ericson e Wollin (1968). . . . . . . . . . . .

Fig. 5.2. Relação entre profundidade e idade das amostras. . . . . . . . . . . . .

Fig. 5.3. Correlação entre a curva do SPECMAP (Martinson et al., 1987) e a curva de isótopos de oxigênio em G.ruber (white) feita com o programa AnalySeries (Paillard et al., 1996) . . . . . . . . . . . . . . . . . . . . . . . . . .

Fig. 5.4. Estimativas de taxas de sedimentação para o testemunho KF02. A linha azul clara indica a taxa de sedimentação de acordo com as idades estimadas para cada amostra analisada do testemunho enquanto a linha azul escuro corresponde à taxa de sedimentação estimada assumindo taxas de sedimentação constantes entre datações consecutivas. A escala vertical do gráfico superior foi dimensionada de maneira a mostrar os dados de todo o testemunho enquanto no gráfico inferior a escala vertical foi reduzida para ampliar e observar melhor as variações na taxa de sedimentação. .

Fig. 5.5. Abundâncias relativas das espécies mais abundantes ao longo do testemunho $\mathrm{KF} 02$. As escalas variam de um gráfico a outro para facilitar a visualização. $\mathrm{O}$ trecho não analisado, compreendido entre 185 e $215 \mathrm{~cm}$ de profundidade, está representado pela linha pontilhada. . . . . . . . . . . . . . . . . . . . . . . . . . .

Fig. 5.6. Abundâncias relativas das espécies que compõem o Plexo menardiforme ao longo do testemunho KF02. Escalas variáveis para auxiliar a visualização. . . . . .

Fig. 5.7. Abundâncias relativas dos dois morfotipos de G. ruber no testemunho KF02 .

Fig. 5.8. Abundâncias relativas de G. sacculifer com e sem saco e a soma de ambos os tipos ao longo do testemunho KF02. . . . . . . . . . . . . . . . . . . . .

Fig. 5.9. Abundâncias relativas de espécies com abundâncias máximas entre 3,2 \% (G. hirsuta) e $8,5 \%$ (N. dutertrei) ao longo do testemunho KF02. . . . . . . . . . .

Fig. 5.10. Abundâncias relativas de espécies com abundâncias máximas menores que $2,4 \%$ ao longo do testemunho KF02. . . . . . . . . . . . . . . . . . . . .

Fig. 5.11. Percentagem de fragmentos de foraminíferos planctônicos em relação ao total de foraminíferos planctônicos ao longo do testemunho KF02. . . . . . . . . 
Fig. 5.12. Isótopos de oxigênio em rocha total (acima) e G. ruber (white) (abaixo). A escala de $\delta^{18} \mathrm{O}$ está invertida, de acordo com o convencionado em estudos paleoceanográficos.Valores em PDB. . . . . . . . . . . . . . . . . . . .

Fig. 5.13. Isótopos de carbono em rocha total (acima) e G. ruber (white) (abaixo). Valores em PDB. . . . . . . . . . . . . . . . . . . . . . . . . . . . .

Fig. 5.14. Estimativas de paleotemperatura de verão, inverno e média anual obtidas para o testemunho KF02 através da aplicação da técnica de RNAs em dados de censos de fauna de foraminíferos planctônicos (gráfico superior). O segundo gráfico apresenta uma estimativa da diferença entre as temperaturas médias de verão e inverno. No gráfico inferior estão plotadas as abundâncias relativas do Plexo menardiforme para comparação. . . . . . . . . . . . . . . . . . . . . . . . . . . . . . .

Fig. 5.15. Estimativas de paleo-SSMs obtidas para o testemunho KF02 a partir da aplicação do método residual. A SSM "local" se refere às estimativas de SSM após a exclusão do efeito do volume de gelo global. A Figura inclui os dados de variação da composição de isótopos de oxigênio em testas de G. ruber (white), as estimativas de volume de gelo e de paleotemperatura de verão os quais foram utilizadas no cálculo das paleossalinidades. . . . . . . . . . . . . . . . . . . . . . . . . . .

Fig. 5.16. Variabilidade de parâmetros relacionados à paleoprodutividade incluindo dados de abundância relativa de G. truncatulinoides (dex) e $N$. dutertrei, razão $G$. bulloides/G. ruber, percentagem de foraminíferos bentônicos e ostracodes e composição de isótopos de carbono em testas de G. ruber (white) . . . . . . . . . .

Fig. 5.17. Estimativas da variação do teor de $\mathrm{CaCO}_{3}$ (gráfico superior) e das razões $\mathrm{Ti} / \mathrm{Ca}$ e $\mathrm{Fe} / \mathrm{Ca}$ (gráfico inferior) na fração fina dos sedimentos ao longo do testemunho KF02 de acordo com dados de Bariani (2009) . . . . . . . . . . . . . . . . .

Fig. 5.18. Relação profundidade-idade dos modelos novo e antigo para o testemunho SAN76.

Fig. 5.19. Correlação entre a curva do SPECMAP (Martinson et al., 1987) e a curva de isótopos de oxigênio em foraminíferos bentônicos do gênero Cibicidoides feita com o programa AnalySeries (Paillard et al., 1996) . . . . . . . . . . . . . . . . .

Fig. 5.20. Estimativas de taxas de sedimentação ao longo do testemunho SAN76 de acordo com os modelos de idade novo e antigo. . . . . . . . . . . . . . . . .

Fig. 5.21. Comparação das estimativas de paleotemperatura superficial do mar de verão (gráfico superior) e inverno (gráfico inferior) obtidas pelos métodos SIMMAX (linha pontilhada) e RNAs (linha contínua) . . . . . . . . . . . . . . . . . .

Fig. 5.22. Comparação das estimativas de paleossalinidade superficial do mar "total" (gráfico superior) e "local", excluindo o efeito do volume de gelo (gráfico inferior) obtidas pelos métodos SIMMAX (linha pontilhada) e RNAs (linha contínua). . . . .

Fig. 5.23. Comparação das variações na abundância relativa das espécies mais representativas ao longo dos testemunhos KF02 e SAN76. . . . . . . . . . . .

Fig. 5.24. Comparação das variações na abundância relativa de $G$. menardii e $G$. 
tumida ao longo dos testemunhos KF02 e SAN76. . . . . . . . . . . . . . . .

Fig. 5.25. Comparação das variações na abundância relativa dos dois morfotipos de $G$. ruber ao longo dos testemunhos KF02 e SAN76. . . . . . . . . . . . . . . .

Fig. 5.26. Variações na composição de isótopos de oxigênio em testas de G. ruber (white) nos testemunhos KF02 e SAN76. . . . . . . . . . . . . . . . . . .

Fig. 5.27. Comparação das variações das estimativas de paleotemperaturas de verão (gráfico superior) e inverno (gráfico inferior) a partir da técnica das RNAs nos testemunhos KF02 e SAN76. As linhas indicativas das TSMs médias de verão, inverno e média anual se referem a dados atuais segundo o WOA05 (Locarnini et al., 2006) . .

Fig. 5.28. Comparação das variações das estimativas de paleotemperatura média anual e da diferença de temperatura de verão menos inverno nos testemunhos KF02 e SAN76. . . . . . . . . . . . . . . . . . . . . . . .

Fig. 5.29. Comparação das variações nas estimativas de paleossalinidade nos testemunhos KF02 e SAN76.

Fig. 5.30. Comparação das variações dos parâmetros relacionados à produtividade ao longo dos testemunhos KF02 e SAN76. De cima para baixo, os dados incluem: abundância relativa de $G$. truncatulinoides (dex) e $N$. dutertrei, razão $G$. bulloides $/ G$. ruber, percentagem de foraminíferos bentônicos e ostracodes e composição de isótopos de carbono em testas de G. ruber (white) . . . . . . . . . . . . . . .

Fig. 5.31. Comparação das abundâncias relativas de fragmentos de foraminíferos planctônicos ao longo dos testemunhos KF02 e SAN76. . . . . . . . . . . . .

Fig. 6.1. Comparação das taxas de sedimentação (gráfico inferior) com as razões Ti/Ca e $\mathrm{Fe} / \mathrm{Ca}$ e o teor de $\mathrm{CaCO}_{3}$ medidos na fração fina (fração menor que $0,063 \mathrm{~mm}$ ) para o testemunho KF02. As setas verdes apontam os máximos e mínimos de taxas de sedimentação e a sua correlação com o aporte de sedimentos terrígenos de acordo com as razões $\mathrm{Ti} / \mathrm{Ca}$ e $\mathrm{Fe} / \mathrm{Ca}$. . . . . . . . . . . . . . . . . . . . . . . . . .

Fig. 6.2. Diferenças entre as estimativas de paleotemperatura baseadas nos métodos SIMMAX e RNAs para o testemunho SAN76, para o verão (acima) e inverno (abaixo). Manteve-se a mesma escala para uma melhor comparação. . . . . . .

Fig. 6.3. Anomalias de TSM ao longo de um transecto sobre a plataforma continental desde a desembocadura do Rio da Prata até aproximadamente a latitude de localização do testemunho SAN76 para um período de 12 anos desde 1982 até 1995 (modificado de Campos et al., 1999; Lentini et al., 2001). Os autores computaram as séries temporais de anomalias de TSM após a exclusão da componente sazonal. As linhas azul e vermelha indicam respectivamente as latitudes dos testemunhos KF02 e SAN76.

Fig. 6.4. Comparação do registro de isótopos de oxigênio em G. ruber e as estimativas de TSM de verão baseadas nas RNAs para os dois testemunhos. . . . . . . . . .

Fig. 6.5. Pendente da relação entre a composição isotópica da água do mar na área de estudo para o oceano moderno e para o UMG, considerando apenas o aumento do volume de gelo e conseqüente aumento de salinidade (Toledo et al., 2007b). . . . . 
Fig. 6.6. Diferentes relações entre salinidade e $\delta^{18} \mathrm{O}$ da água do mar para o Oceano Atlântico (à esquerda) e os seus efeitos nas estimativas de paleossalinidade (à direita). Adaptado de Toledo et al. (2007b). Todos os dados correspondem a profundidades entre 0 e $250 \mathrm{~m}$. . . . . . . . . . . . . . . . . . . . . . . . . . . . . .

Fig. 6.7. Relação entre salinidade e balanço E-P: (a) Variação da salinidade superficial média de todos os oceanos e do balanço E-P em função da latitude (Pickard e Emery, 1990), (b) salinidade superficial e balanço E-P no Oceano Atlântico (Curry et al., 2003). Observa-se a forte correlação entre a salinidade e o balanço E-P e a influência das correntes oceânicas na suavização e deslocamento dos valores máximos subtropicais. . . . . . . . . . . . . . . . . . . . . . . . . . . . . .

Fig. 6.8. Comparação das estimativas de composição isotópica da água do mar para os dois testemunhos e a variação da insolação de dezembro e janeiro em $25^{\circ} \mathrm{S}$ (testemunho SAN76 no gráfico superior, e testemunho KF02 no gráfico intermediário) e variações das razões Ti/Ca e Fe/Ca para o testemunho KF02 (gráfico inferior). Os dados de insolação foram obtidos com o uso do programa desenvolvido pelo Prof. L.D.Roper (Virginia Polytechnic Institute and State University) de acordo com a solução de Berger (1978), programa disponível na página web http://arts.bev.net/roperldavid/InsolationCodes.htm. . . . . . . . . . . . . . .

Fig. 6.9. Registro de isótopos de carbono em rocha total e em G. ruber no testemunho KF02.

Fig. 6.10. Variação de $\delta^{13} \mathrm{C}$ da água do mar em função da profundidade na estação do GEOSECS mais próxima à área de estudo (estação $57 ; 23,98^{\circ} \mathrm{S} ; 35,02^{\circ} \mathrm{W}$ ). As linhas pontilhadas azul e vermelha indicam respectivamente as profundidades de coleta dos testemunhos KF02 e SAN76. . . . . . . . . . . . . . . . . . . . . . .

Fig. 6.11. Estimativas de paleotemperatura média anual e paleossalinidade para os testemunhos KF02 (gráfico superior) e SAN76 (gráfico inferior). Os triângulos amarelos indicam as amostras datadas por ${ }^{14} \mathrm{C}$. As seções sombreadas indicam os períodos para os quais foram estimadas as maiores paleoprodutividades. A parte inferior da figura inclui a sequiência de eventos (globais ou não) ocorridos durante o período analisado (ver capítulo 3) . . . . . . . . . . . . . . . . . . . . . .

Fig. 6.12. Comparação das estimativas de composição isotópica da água do mar (após extração do efeito do volume de gelo) e as curvas de insolação de verão para $25^{\circ} \mathrm{S}$ com o contraste sazonal definido como a diferença entre as temperaturas de verão e inverno. Estão destacados os eventos de degelo de 19 mil anos (MWP), 14 mil anos (MWP1a) e 8,2 mil anos AP, assim como o período correspondente ao evento YD, no testemunho KF02. . . . . . . . . . . . . . . . . . . . . . . . . . . . .

Fig. 6.13. Comparação das estimativas de paleotemperatura superficial na região de estudo e na região de Benguela de acordo com dados de Farmer et al. (2005). Os dados de Farmer et al. se baseiam em medidas da razão $\mathrm{Mg} / \mathrm{Ca}$ em testas de G.bulloides. Os triângulos indicam as datações e estão sinalizados de acordo com a cor da respectiva curva. . . . . . . . . . . . . . . . . . . . . . . . . . 
Tabela 4.1. Lista de grupos taxonômicos considerados na obtenção de estimativas de paleotemperaturas aplicando a técnica de RNAs. . . . . . . . . . . . . . .

Tabela 5.1. Datações de radiocarbono e respectivas estimativas de idades calendário para o testemunho KF02. . . . . . . . . . . . . . . . . . . . . . . . . .

Tabela 5.2. Lista das espécies e morfotipos identificados nos censos de fauna do testemunho KF02. . . . . . . . . . . . . . . . . . . . . . . . . . . .

Tabela 5.3. Abundâncias relativas mínimas, médias e máximas das espécies identificadas ao longo do testemunho KF02. Espécies listadas de acordo com as suas abundâncias relativas. . . . . . . . . . . . . . . . . . . . . . . . .

Tabela 5.4. Desvios padrão máximo, mínimo e médio $\left({ }^{\circ} \mathrm{C}\right)$ das estimativas de paleotemperatura obtidas pela técnica de RNAs para o testemunho KF02. . . . . .

Tabela 5.5. Datações de radiocarbono e respectivas estimativas de idades calendário para o testemunho SAN76. . . . . . . . . . . . . . . . . . . . . . . . .

Tabela 5.6. Comparação dos valores máximos, mínimos e médios de paleotemperaturas $\left({ }^{\circ} \mathrm{C}\right)$ estimadas pelos métodos de RNAs e SIMMAX. . . . . .

Tabela 5.7. Desvios padrão máximo, mínimo e médio $\left({ }^{\circ} \mathrm{C}\right)$ das estimativas de paleotemperatura obtidas pela técnica de RNAs para o testemunho SAN76. . . . .

Tabela 6.1. Estimativas de paleotemperaturas para o UMG das amostras do Projeto MARGO próximas à área de estudo. . . . . . . . . . . . . . . . . . . . .

Tabela 6.2. Valores médios de paleotemperatura para as amostras pertencentes ao período entre 19 e 23 mil anos AP do testemunho SAN76 e anomalias em relação aos valores atuais definidos pelo WOA05. . . . . . . . . . . . . . . . . . . .

Tabela 6.3. Relação das espécies G. bulloides e G.ruber com algumas variáveis ambientais e biológicas importantes, de acordo com Toledo et al., (2008) . . . . . 


\section{RESUMO}

O objetivo da presente tese é o de documentar, em escala milenar, as variações paleoclimáticas e paleoceanográficas superficiais do Atlântico Sul Ocidental desde o Último Máximo Glacial. Com esta finalidade, foram obtidas estimativas de paleotemperatura, paleossalinidade e paleoprodutividade baseadas na análise de fauna de foraminíferos planctônicos, isótopos estáveis de oxigênio e carbono em Globigerinoides ruber e nove datações de radiocarbono em amostras de um testemunho coletado na Bacia de Santos. Os dados foram complementados com a reanálise de outro testemunho previamente coletado em outro setor da mesma Bacia. Os resultados demonstram que as mudanças paleoceanográficas registradas no período analisado podem ser parcialmente explicadas por variações na exportação de calor e sal para o hemisfério norte relacionadas à atividade da célula de transporte meridional e à configuração das correntes superficiais associadas à circulação atmosférica. Outra parte significativa da variabilidade parece estar relacionada à intensidade do Sistema de Monção da América do Sul resultante de variações na insolação de acordo com o ciclo de precessão. Os principais desvios da tendência de variação da composição isotópica da água do mar esperada em função das mudanças de insolação coincidem com os grandes pulsos de degelo ocorridos em torno de 19, 14 e 8,2 mil anos AP.

Palavras-chave: Paleoceanografia, Bacia de Santos, Último Máximo Glacial, Deglaciação, Holoceno, Foraminíferos Planctônicos, Redes Neurais Artificiais, Sistema de Monção da América do Sul. 


\begin{abstract}
The goal of this thesis is to document the paleoclimatic and paleoceanographic changes occurred at the millennial scale since the Last Glacial Maximum at the surface Western South Atlantic. Paleotemperature, paleosalinity and paleoproductivity estimates were obtained for this purpose based on faunal changes of foraminifera assemblages, carbon and oxygen stable isotopes in Globigerinoides ruber and nine radiocarbon datings in a core retrieved at Santos Basin. These data were supplemented by the reanalysis of a second core previously analyzed from a different sector of the same basin. The results demonstrate that paleoceanographic changes recorded in the analyzed period may be partially explained by changes in the heat and salt export to the northern hemisphere related to the meridional overturning cell and the surface currents related to atmospheric circulation. Another significant portion of the observed variability seems to be related to changes in the strength of the South American Monsoon System resulting from insolation changes according to the precessional cycle. The main departures from the expected trend of variation in the isotopic composition of seawater related to insolation changes coincide with great meltwater pulses occurred around 19,14 , and $8.2 \mathrm{kyr} \mathrm{BP}$.
\end{abstract}

Keywords: Paleoceanography, Santos Basin, Last Glacial Maximum, Deglaciation, Holocene, planktonic foraminifera, Artificial Neural Networks, South American Monsoon System. 


\section{Nota sobre nomenclatura}

\section{Amostras}

Visando simplificar, as profundidades das amostras mencionadas ao longo da tese se referem às profundidades médias. Assim, por exemplo, a amostra de $45 \mathrm{~cm}$ representa o intervalo de profundidades compreendido entre 44 e $46 \mathrm{~cm}$.

\section{Análises isotópicas}

Os resultados das análises isotópicas são apresentados pela notação mais usual delta $(\delta)$ :

$$
\delta=\left[\left(\mathrm{R}_{\text {amostra }}-\mathrm{R}_{\text {padrão }}\right) / \mathrm{R}_{\text {padrão }}\right] \times 1000
$$

onde $\mathrm{R}_{\text {amostra }}$ e $\mathrm{R}_{\text {padrão }}$ representam a razão da abundância do isótopo pesado em relação ao leve na amostra e no padrão de referência, respectivamente. No caso dos isótopos de oxigênio, mede-se a razão ${ }^{18} \mathrm{O} /{ }^{16} \mathrm{O}$ e no caso do carbono a razão ${ }^{13} \mathrm{C} /{ }^{12} \mathrm{C}$. Valores de $\delta$ são expressos em partes por mil (\%). O padrão para isótopos de carbono e oxigênio em carbonatos é o Vienna Pee Dee Belemnite (VPDB) ou simplesmente PDB, Já para a água do mar o padrão é o Vienna Standard-Mean-Ocean-Water (VSMOW) ou simplesmente SMOW.

\section{Idades}

Exceto onde especificado, as idades mencionadas se referem a anos calendário antes do presente (AP) sendo o presente definido como o ano 1950. 


\section{Lista de siglas e abreviações:}

\begin{tabular}{|c|c|}
\hline AAF & Água Antártica de Fundo \\
\hline $\mathrm{AC}$ & Água Costeira \\
\hline ACAS & Água Central do Atlântico Sul \\
\hline ACR & Antarctic Cold Reversal ou Reversão Fria Antártica \\
\hline ACS & Água Circumpolar Superior \\
\hline AIA & Água Intermediária Antártica \\
\hline APAN & Água Profunda do Atlântico Norte \\
\hline ASAS & Alta Subtropical do Atlântico Sul \\
\hline $\mathrm{AT}$ & Água Tropical \\
\hline $\mathrm{B} / \mathrm{A}$ & Evento Bolling Allerod \\
\hline CAS & Corrente do Atlântico Sul \\
\hline $\mathrm{CB}$ & Corrente do Brasil \\
\hline $\mathrm{CBe}$ & Corrente de Benguela \\
\hline CLIMAP & Climate Long-Range Investigation, Mapping and Prediction \\
\hline CNB & Corrente Norte do Brasil \\
\hline COHMAP & Cooperative Holocene Mapping Project \\
\hline CSE & Corrente Sul Equatorial \\
\hline CTH & Circulação Termohalina \\
\hline ENOS & El Niño - Oscilação Sul \\
\hline EPILOG & Environmental Processes of the Ice age: Land, Oceans, Glaciers \\
\hline FRX & Fluorescência de Raios X \\
\hline GEOSECS & Geochemical Ocean Sections Study \\
\hline GLAMAP & Glacial Atlantic Ocean Mapping \\
\hline H1 & Evento Heinrich 1 \\
\hline IRD & Ice Rafted Debris \\
\hline LaPAS & Laboratório de Paleoceanografia do Atlântico Sul \\
\hline MARGO & Multiproxy Approach for the Reconstruction of the Glacial Ocean Surface \\
\hline MOC & Meridional Overturning Cell ou Célula de Revolvimento Meridional \\
\hline MWP1a & Pulso de Degelo 1a \\
\hline PMIP2 & Paleoclimate Modeling Intercomparison Project (Fase 2) \\
\hline SMAS & Sistema de Monção da América do Sul \\
\hline SPECMAP & Spectral Mapping Project \\
\hline SSM & Salinidade Superficial do Mar \\
\hline TSM & Temperatura Superficial do Mar \\
\hline UMG & Último Máximo Glacial \\
\hline WOA05 & World Ocean Atlas 2005 \\
\hline WOA98 & World Ocean Atlas 1998 \\
\hline YD & Younger Dryas \\
\hline ZCAS & Zona de Convergência do Atlântico Sul \\
\hline ZCIT & Zona de Convergência Intertropical \\
\hline
\end{tabular}




\section{Agradecimentos}

Ao CNPq pelo auxílio financeiro.

Ao meu orientador, Prof. Dr. Felipe Toledo por ter me contagiado o entusiasmo pela paleoceanografía e ter acreditado em mim e me dado a oportunidade de fazer a tese no LaPAS apesar da situação pouco convencional. Agradeço a orientação na tese e profissional, a amizade, a hospedagem e a tele-entrega mais rápida de PDFs que conheço.

A Prof. Dra. Karen Costa por toda a ajuda ao longo do trabalho, pelas dicas, por ser uma grande amiga e "quase mãe" no meu tempo em São Paulo e também pelas boas risadas!

À Petrobras pelo material cedido.

Aos Profs. Dr. Michel Michaelovitch de Mahiques e. Dra. Rosalinda C. Montone pelo apóio dado respectivamente como Presidente e Coordenadora do Programa de Oceanografia Química e Geológica da Comissão de Pós Graduação.

Ao Prof. Dr. Ricardo Norberto Ayup-Zouain pelos comentários e sugestões ao longo do trabalho.

Ao Prof. de Fotografia, Dr. Eduardo Masami Kitahara por toda a ajuda com as fotografias estereoscópicas dos foraminíferos.

A todos os membros do LaPAS, mas especialmente à Ana Cláudia, Bia, Mariana, Lucas e Louise pelo auxílio no laboratório e à Juliana, Edmundo e Paula pelas boas conversas.

A Ana Paula e Silvana, pelo atendimento sempre atencioso na Secretaria da Pós.

A TODA a turma do Laboratório de Microfósseis Calcários da UFRGS e especialmente ao Prof. Dr. João C. Coimbra pela minha "adoção".

Ao Prof. Elírio Toldo Jr pelo apóio oferecido desde o início.

Ao Cristianini pela consulta de última hora.

Finalmente, agradeço a minha família: o Nelson que me acompanha desde sempre e me incentiva a crescer; o Pedro que me acompanhou nas disciplinas e até em saída de campo e o Diego que fez todo o trabalho de lupa pacientemente comigo. Melhor companhia eu não podia ter!

Agradeço também a minha sogra Carmen quem sempre esteve pronta para me dar uma mão e aos meus pais que me incentivaram mesmo à distância. 


\section{INTRODUÇÃO}

O objetivo da presente tese é o de documentar, em escala milenar, as variações paleoclimáticas e paleoceanográficas superficiais do Atlântico Sul Ocidental desde o Último Máximo Glacial (UMG). Para atender o objetivo, os foraminíferos planctônicos foram escolhidos como ferramenta de estudo. A motivação e justificativa desta tese podem ser resumidas por cinco questionamentos.

\section{Por que estudar o clima e os oceanos no passado?}

A melhor maneira de procurar respostas para os questionamentos sobre o clima no futuro é olhando para o passado. À medida que um registro mais detalhado e confiável das flutuações paleoclimáticas é construído, aumenta a possibilidade de identificar as causas e mecanismos de variação (Bradley, 1985, 2000). É graças aos avanços significativos nas pesquisas paleoclimáticas das últimas décadas, que as idéias sobre os mecanismos responsáveis pelas mudanças climáticas deixaram de ser mera especulação para se tornar hipóteses específicas, testáveis, suportadas por simulações quantitativas (Rahmstorf, 2002). Os avanços foram impulsionados pelo crescente número de dados de boa resolução temporal, com cobertura espacial cada vez mais ampla, pelo aprimoramento das técnicas de análise e pelo desenvolvimento de modelos numéricos cada vez mais precisos.

A capacidade de um modelo reproduzir diferentes padrões espaciais e variações regionais é uma medida da sua confiabilidade e potencial aplicabilidade para prever futuras mudanças climáticas. Os modelos devem ser capazes de reproduzir não apenas o clima do presente, mas também o clima sob diferentes condições de contorno. Como os registros instrumentais de variáveis climáticas abrangem uma fração mínima da história climática da Terra eles se limitam a um espectro de variações climáticas muito pequeno. Desta forma, os dados paleoclimáticos são indispensáveis para uma correta calibração por proporcionarem uma perspectiva real sobre as variações climáticas e a evolução do clima.

\section{Quais variáveis considerar?}

Atualmente é comum vermos a discussão das mudanças climáticas passadas e futuras enquadradas dentro de diferentes modos de circulação oceânica, principalmente 
relacionados aos modos de circulação do Oceano Atlântico (por ex. Sarnthein et al., 1994). De acordo com as definições clássicas, a circulação oceânica é dividida em uma componente superficial regida pelos ventos e outra termohalina, regida por variações de densidade (por ex. Pickard e Emery, 1990). Na realidade, porém, é impossível dissociar a circulação termohalina da circulação superficial (Rahmstorf, 2003) e o que é definido como circulação termohalina também é fortemente dependente dos ventos e das condições oceanográficas superficiais (Wunsch, 2002). A melhor prova disto é que as variações de densidade que afetam a circulação termohalina global são determinadas pelos fluxos de calor e água que ocorrem na superfície do oceano (Rahmstorf, 1996) e daí a importância fundamental de se estudar as mudanças da hidrografia superficial no passado.

Da mesma maneira em que a maior parte dos conhecimentos do oceano moderno se baseia em medidas das propriedades da água tais como temperatura e salinidade, uma completa reconstrução paleoceanográfica deve, necessariamente, incluir estimativas destas variáveis. De fato, as estimativas de paleotemperatura são rotina na maior parte das reconstruções paleoceanográficas. Comparativamente, e apesar da importância da salinidade, estimativas de paleossalinidade são escassas devido principalmente às limitações dos métodos existentes.

Embora a circulação termohalina seja basicamente regida por variações de temperatura (Rahmstorf, 2006), o resfriamento intenso das águas em altas latitudes nem sempre é capaz de aumentar suficientemente a densidade como para permitir o afundamento da água. Nesse ponto, a salinidade passa a exercer um papel chave na determinação dos locais onde podem ser formadas águas profundas (Boyle, 1990). De fato, diversos modelos têm demonstrado a sensibilidade da circulação termohalina a variações na salinidade, principalmente a variações induzidas pelo aporte de águas de degelo em altas latitudes do oceano Atlântico seja do Norte (por ex. Manabe e Stouffer, 1997; Stocker e Marchal, 2000; Dahl et al., 2005) ou do Sul (Weaver et al., 2003), mas também a variações no oceano Atlântico tropical (Goelzer et al., 2006). Portanto, dada a importância da salinidade, mesmo uma estimativa semiquantitativa é válida (Mix et al., 2001).

Por outra parte, a produtividade biológica nos oceanos constitui uma componente fundamental no sistema climático e, portanto, além do estudo da paleotemperatura e paleossalinidade, o estudo da paleoprodutividade é essencial. Ao mesmo tempo em que as flutuações na produtividade influem no clima através da 
alteração das concentrações de $\mathrm{CO}_{2}$ atmosférico elas também fornecem indícios sobre as variações oceanográficas e atmosféricas passadas como, por exemplo, sobre o regime de ventos e os processos de ressurgência.

\section{Por que estudar o final do Quaternário?}

O final do Quaternário é um período particularmente importante de ser estudado, por ter sido palco de mudanças extremas, desde condições plenamente glaciais até o atual interglacial, passando por um período de transição com mudanças climáticas abruptas. Portanto, o conhecimento das mudanças ocorridas neste período permite testar os modelos sob condições extremas. Por outra parte, o fato de ser um período

relativamente recente significa que a configuração dos continentes é a mesma de hoje em dia (exceto pelas variações relacionadas às mudanças do nível do mar) e que as espécies que compõem a fauna estudada são as mesmas que existem atualmente, o que permite uma boa calibração dos diferentes indicadores utilizados.

\section{Por que estudar a margem ocidental do Atlântico Sul?}

Apesar de representarem uma parte muito pequena dos oceanos, as margens continentais têm um impacto significativo nos ciclos biogeoquímicos globais devido ao intenso processamento geoquímico e biológico do carbono e outros elementos e pela troca de grandes quantidades de matéria e energia com o oceano aberto (Robbins et al., 2009). Por outra parte, além de ser a única bacia oceânica onde o transporte de calor ocorre na direção do equador, o Atlântico Sul é importante por ser a "estrada" através da qual ocorre a principal troca interoceânica de massas d'água e conseqüentemente de calor e sal (Müller, et al., 1998). Apesar disto, comparado ao Atlântico Norte, o Atlântico Sul ainda é pouco explorado e a margem ocidental é menos explorada ainda do que a margem oriental.

\section{Por que usar os foraminíferos?}

Estudos paleoclimáticos dependem da análise de registros indiretos ou proxies, ou seja, registros de variáveis que indiretamente refletem variações climáticas. Há mais de meio século, os foraminíferos surgiram como os principais portadores de informação para a paleoceanografia (Berger et al., 1981) e hoje são amplamente utilizados com esta finalidade. Algumas propriedades dos foraminíferos planctônicos ou assembléias de foraminíferos planctônicos utilizadas como proxies são as variações na composição 
faunal (por ex. Imbrie e Kipp, 1971; Pflaumann et al., 1996), o sentido de enrolamento (por ex. Ericson et al., 1955; Naidu e Malmgren, 1996), a composição isótopica (por ex. Emiliani, 1954; Shackleton, 1982), o conteúdo de elementos traços (por ex. Lea e Boyle, 1991; Nürnberg et al., 1996) e o tamanho das testas (por ex. Schmidt et al., 2003a, 2003b). Tais variações são utilizadas para estimar diversas variáveis incluindo paleotemperatura, paleossalinidade, paleoprodutividade e profundidade da camada de mistura.

Ruddiman (1977) elaborou um mapa global classificando as diferentes regiões oceânicas em três categorias de acordo com a aplicabilidade dos foraminíferos em estudos paleoceanográficos. A classificação se baseia em fatores como as condições de preservação do registro sedimentar (efeitos da dissolução) e a potencial influência de outros fatores interferentes tais como correntes que possam retrabalhar os sedimentos de fundo. De acordo com esta classificação, a margem ocidental do Atlântico Sul apresenta as condições ideais para a utilização de foraminíferos em reconstruções paleoceanográficas. 


\section{2. ÁREA DE ESTUDO}

Neste capítulo são descritas as características da área de localização dos testemunhos analisados na presente tese assim como o papel do Atlântico Sul no contexto global.

\subsection{CONTEXTO GEOMORFOLÓGICO E SEDIMENTAR}

Os testemunhos analisados na presente tese foram coletados no talude da Bacia de Santos. Esta Bacia está localizada na margem continental sul brasileira entre as Bacias de Campos ao norte e de Pelotas ao sul sendo os limites marcados respectivamente pelos Altos de Cabo Frio e de Florianópolis. Do ponto de vista geomorfológico, os testemunhos estão localizados no Embaiamento de São Paulo (Fig. 2.1).

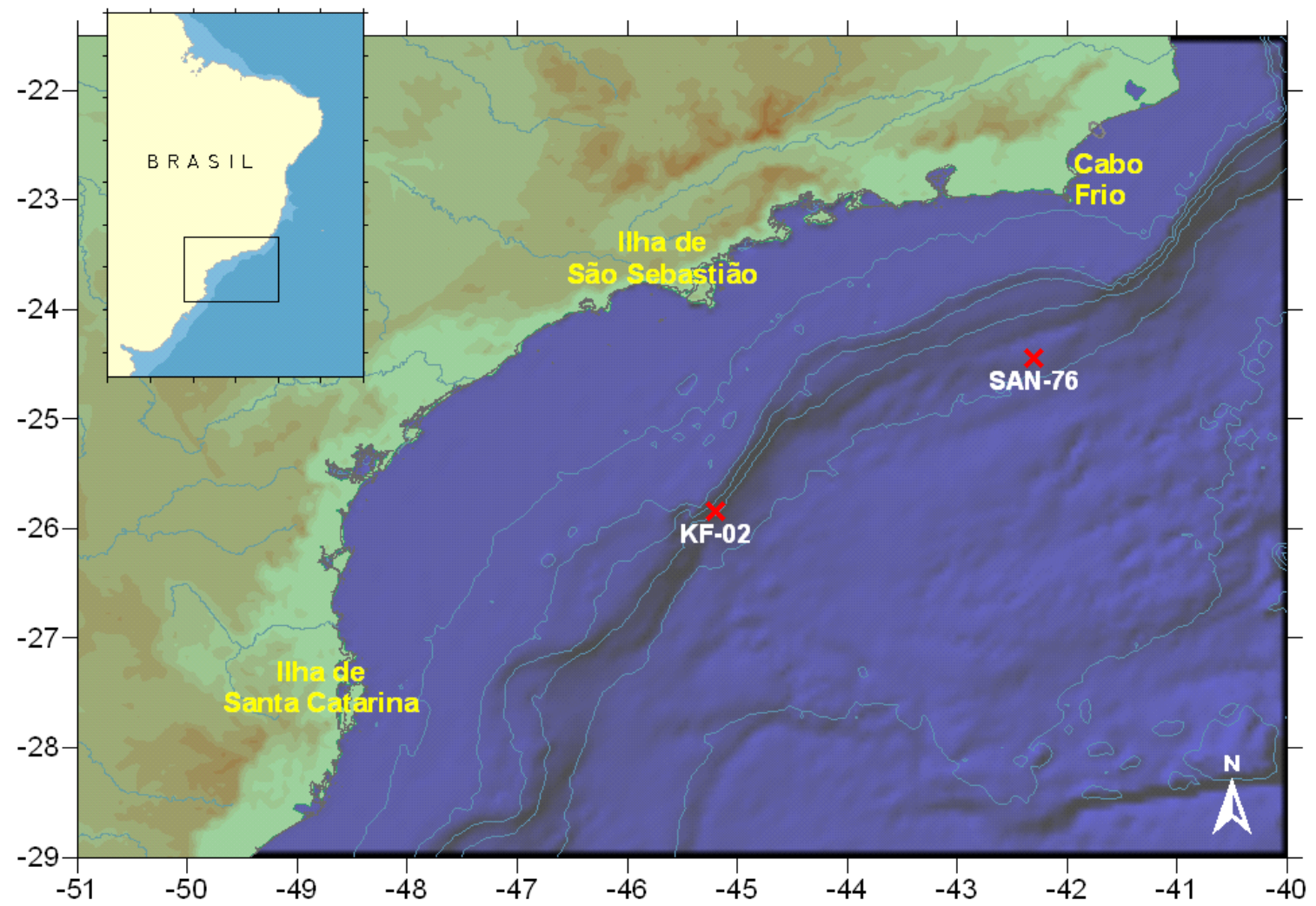

Fig. 2.1. Localização dos testemunhos analisados. Mapa construído a partir de dados de linha de costa e rios do Coastline Extractor do NGDC/NOAA e dados batimétricos de Smith e Sandwell, 1997. As isóbatas desenhadas correspondem às profundidades iguais a 100, 200, 500, 1000, 2000 e $3000 \mathrm{~m}$. 
A margem sul brasileira (entre $19^{\circ} \mathrm{S}$ e $38^{\circ} \mathrm{S}$ ) foi descrita em detalhe por Zembruscki (1979). De acordo com o autor, a plataforma continental apresenta-se consideravelmente ampla, com relevo geral suave e com contornos batimétricos que acompanham a configuração da costa. A largura máxima da plataforma localiza-se no setor do Embaiamento de São Paulo, aproximadamente na altura de Santos, com 230 km de extensão. No Embaiamento, a quebra da plataforma ocorre entre 120 e 180m de profundidade e o talude continental, apresenta uma largura entre 59 e $122 \mathrm{~km}$ e uma declividade entre $1^{\circ}$ e $1^{\circ} 45^{\prime}$. O talude superior é mais estreito e íngreme do que o inferior.

$\mathrm{Na}$ área da Bacia de Santos, a planície costeira é muito estreita e, especialmente na área central entre Rio de Janeiro e Santos, a costa apresenta uma série de grandes baías e ilhas resultantes do afloramento do embasamento Pré-Cambriano (Duarte e Viana, 2007). A presença da Serra do Mar impede a chegada de grandes cursos d'água e condiciona os rios a drenarem para o oeste. Os rios que deságuam no mar apresentam dimensões reduzidas, tanto geometricamente quanto em termos de fluxo (Conti e Furtado, 2006), portanto os aportes atuais de sedimentos terrígenos para a plataforma continental são reduzidos. A situação era diferente durante o último glacial, quando o nível do mar baixo expôs a plataforma continental favorecendo o aporte de sedimentos (Kowsmann e Costa, 1979). Isto significa que a maior parte das mudanças em termos de aporte de sedimentos terrígenos na área de estudo está relacionada a variações do nível do mar e que, de maneira geral, a sedimentação Quaternária ocorreu predominantemente durante os períodos de nível do mar baixo (Milliman, 1978). Com a progressiva elevação do nível do mar durante o Holoceno, houve uma diminuição da sedimentação terrígena (Mahiques et al., 2002).

A partir do estudo da margem continental da América do Sul entre 20 e $50^{\circ} \mathrm{S}$ desde a plataforma externa até profundidades abissais, Frenz et al. (2003) concluem que os padrões de sedimentação observados podem ser atribuídos principalmente a diferenças nas condições climáticas (intemperismo), localização geográfica (presença de rios) e produção marinha e que, secundariamente, podem ser fortemente modificados pela circulação oceânica. Na faixa de latitudes estudada pelos autores, se distingue uma área ao norte, caracterizada por menores granulometrias e um maior teor de carbonato e outra área ao sul, de granumoletria grossa e baixos teores de carbonato. A transição entre ambas as áreas é definida pela Confluência das Correntes do Brasil e Malvinas. Na 
região altamente produtiva da Confluência, os sedimentos se caracterizam por elevadas concentrações de carbono orgânico e baixos teores de carbonato.

Olhando em menor escala, especificamente apenas na região do Embaiamento de São Paulo, as condições climáticas são mais homogêneas e a sedimentação na área externa da plataforma e talude superior parece ser uma resposta combinada à morfologia de fundo, ao fluxo lateral (perpendicular às isóbatas) associado ao meandramento da Corrente do Brasil e ao transporte da Água Costeira na direção do mar aberto (Mahiques et al., 2002). De acordo com estudo de Mahiques et al. (2004), na plataforma e talude superior do Embaiamento, a área frente à Ilha de São Sebastião marca o limite entre duas zonas de sedimentação distintas tanto na fração orgânica como inorgânica. Na área ao sul, os processos deposicionais estão associados à penetração sazonal de uma pluma de baixa salinidade e baixa temperatura relacionada à descarga fluvial do Rio da Prata (ver seções 2.3.2, 2.3.4). A interação desta pluma com os meandros da Corrente do Brasil favorece a produtividade o que se reflete no teor de matéria orgânica nos sedimentos. A razão de isótopos de neodímio também sugere uma contribuição de sedimentos alóctones o que reforça a hipótese da influência das águas oriundas do Rio da Prata (Mahiques et al., 2004; 2008).

De acordo com os mesmos autores, na área ao norte da Ilha de São Sebastião, a relativa heterogeneidade dos sedimentos sugere uma hidrodinâmica complexa. Ali, os setores com baixas taxas de sedimentação estão associados ao fluxo principal da Corrente do Brasil, o qual impediria a deposição. Na plataforma interna, a distribuição da fração orgânica está relacionada à ressurgência costeira (ver seção 2.3.4).

\subsection{CLIMA}

A região de estudo se encontra próximo ao limite entre as zonas tropical e subtropical. O clima do continente na região de estudo é o tropical atlântico.

O padrão de circulação atmosférica na região é determinado fundamentalmente pelo Anticiclone semifixo associado à Alta Subtropical do Atlântico Sul (ASAS). A ASAS é responsável pela predominância de ventos de NE na região sudeste, tanto no verão quanto no inverno (Bastos e Ferreira, 2000). A posição da ASAS varia ao longo do ano em função das mudanças de temperatura sobre o oceano e o continente. Em 
fevereiro, a ASAS localiza-se mais a sudeste, enquanto no inverno atinge a sua posição mais noroeste (Hastenrath, 1991).

Embora não afete diretamente à área onde dos testemunhos analisados nesta tese, a Zona de Convergência Intertropical (ZCIT) constitui outro elemento fundamental do clima tropical e da circulação oceânica. A ZCIT está localizada no ramo ascendente da célula de Hadley atuando no sentido de transferir calor e umidade dos níveis inferiores da atmosfera das regiões tropicais para os níveis superiores da troposfera e para as médias e altas latitudes (Ferreira, 1996). Na ZCIT ocorre a convergência dos ventos alísios de NE e SE. A ZCIT muda a sua posição e configuração ao longo do ano (Fig. 2.2). De acordo com Melo et al. (2002), entre julho e setembro a ZCIT atinge a sua posição mais ao norte e apresenta um comportamento mais zonal. Em novembro e dezembro, a ZCIT inicia seu deslocamento para o sul. A posição mais ao sul próximo ao litoral brasileiro é atingida em março e abril quando o sistema apresenta uma inclinação climatológica sudoeste-nordeste.
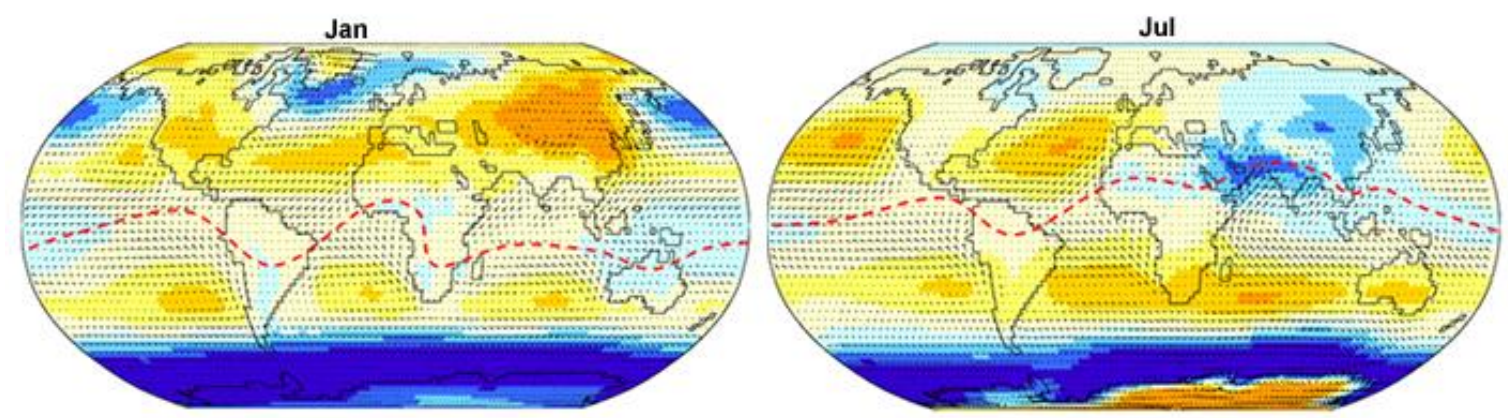

925100010051010101510201025 mb

Fig. 2.2. Mudança sazonal da localização da ZCIT. A linha pontilhada em vermelho marca a posição média da ZCIT em janeiro (à esquerda) e julho (à direita). A escala de cores representa a pressão ao nível do mar. Fonte: NCEP/NCAR Reanalysis Project, 1959-1997 Climatologies, Departamento de Geografia da Universidade do Oregon, EUA.

Os sistemas frontais são um dos maiores causadores de distúrbios meteorológicos sobre o país (Lemos e Calbete, 1996). A formação destes sistemas está relacionada ao encontro da massa tropical marítima associada ao anticiclone do Atlântico Sul e a massa polar associada ao anticiclone móvel polar. Os sistemas frontais são ativos em todas as estações do ano e influem significativamente nos regimes de temperatura e precipitação (Nobre at al. 1986). Embora os sistemas frontais sejam mais 
freqüentes na primavera e inverno (Nobre et al., 1986; Andrade e Cavalcanti, 2004) é no verão que eles têm uma permanência maior associada à atividade convectiva na Zona de Convergência do Atlântico Sul (ZCAS, ver seção 2.2.1) (Satyamurty et al., 1998 apud Rodrigues et al., 2004).

\subsubsection{A precipitação e o Sistema de Monção da América do Sul}

A precipitação no sudeste do Brasil segue um padrão claramente sazonal, com a maior parte da precipitação ocorrendo entre Setembro e Abril, associada ao Sistema de Monção da América do Sul (SMAS) (Zhou e Lau, 1998). No inverno, a precipitação tem uma origem extratropical associada ao aumento na frequiência da incidência de ciclones migratórios ao longo da costa do Atlântico subtropical (Gan e Rao, 1991). A Fig.2.3 apresenta claramente os padrões contrastantes na precipitação de verão (de monção) e de inverno.

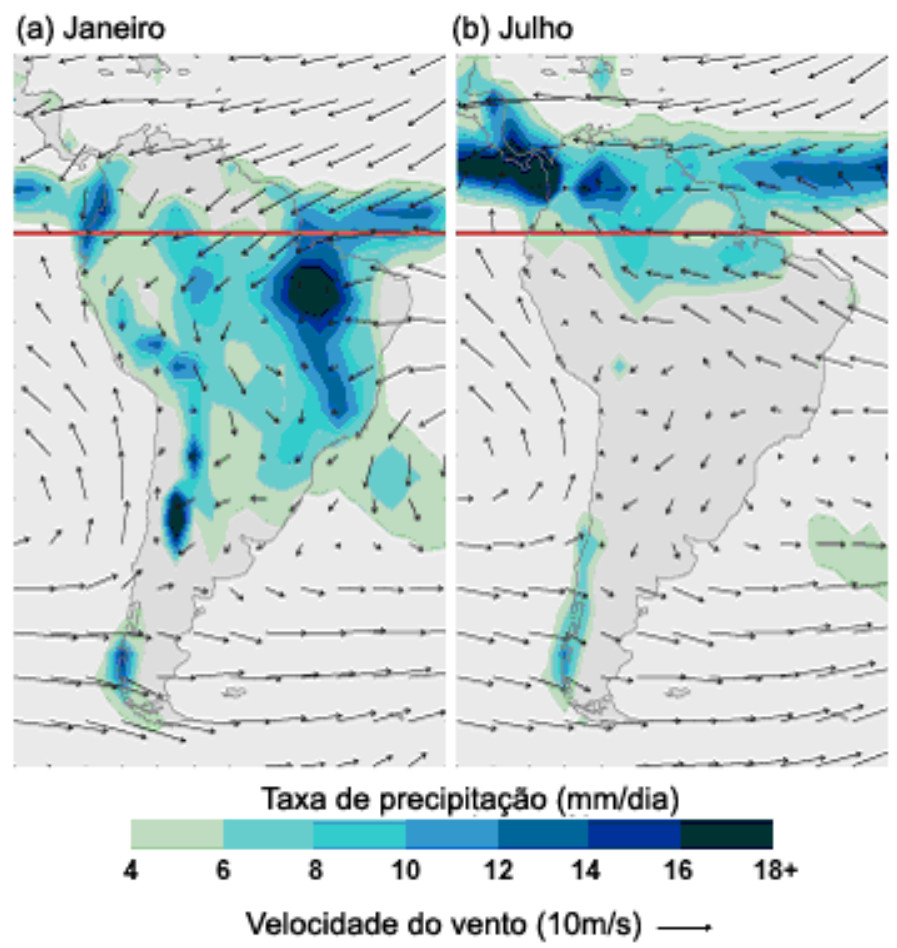

Fig. 2.3. Velocidade média do vento em superfície (vetores) e taxas de precipitação (escala de cores) segundo estimativas de radiômetro de microondas a bordo do satélite Tropical Rainfall Measuring Mission (TRMM) para (a) Janeiro e (b) Julho (Fonte: NASA Earth Observatory). 
As principais feições do SMAS estão representadas esquematicamente na Fig. 2.4. Como todos os sistemas de monção, o SMAS é forçado pelo contraste térmico entre o mar e o continente, o qual segue um ciclo sazonal. A circulação de altos níveis inclui um ciclone centrado próximo a $15^{\circ} \mathrm{S}, 65^{\circ} \mathrm{W}$ e um cavado próximo à costa nordeste do Brasil (Vera et al., 2006). Em baixos níveis, uma queda pronunciada de pressão na área do Gran Chaco que começa no início da primavera em resposta ao rápido aquecimento da superfície resulta em um ciclone de baixos níveis bem desenvolvido durante o verão (a "Baixa do Chaco"). O gradiente de pressão resultante entre a Alta Subtropical do Atlântico Sul e a Baixa do Chaco favorece um fluxo do nordeste e fluxo de ar úmido do Atlântico para o continente (Paegle et al., 2002). O fluxo de umidade é intensificado localmente ao longo da escarpa leste dos Andes, onde se desenvolve o Jato de baixos níveis com os ventos mais intensos sobre a Bolívia. Uma vez que o fluxo de umidade sobre o continente é regulado pelos ventos alísios resultantes dos ramos equatoriais das altas subtropicais do Atlântico norte e sul, mudanças na localização e intensidade destas e a variabilidade concomitante da TSM influem o clima da América do Sul (Paegle e Mo, 2002).

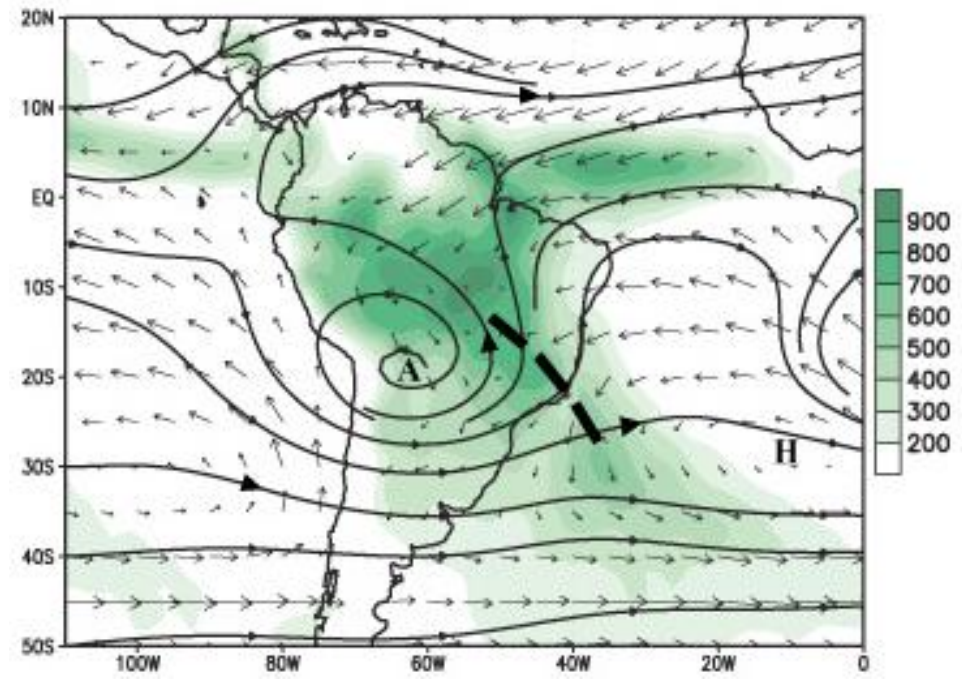

Fig. 2.4. Vetores de vento em $925 \mathrm{hPa}$, linhas de vento em $200 \mathrm{hPa}$ e estimativas de precipitação baseadas em dados satelitais e estações meteorológicas (ver escala de cores) segundo dados de reanálise do NCEP/NCAR de 1979 a 1997 para os meses de dezembro a fevereiro. A linha grossa pontilhada marca a o eixo aproximado da ZCAS. As letras "A" e "H" marcam respectivamente a localização da Alta da Bolívia e da Alta Subtropical do Atlântico Sul. (Fonte: CLIVAR/VAMOS). 
Atualmente, a fase madura do SMAS ocorre do fim de novembro até o fim de fevereiro, quando a principal atividade convectiva se concentra no Brasil central associado a uma banda de nebulosidade e precipitação que se estende do sul da Amazônia em direção ao sudeste do Brasil e Atlântico Sul adjacente. Esta banda convectiva de orientação NW-SE é conhecida como Zona de Convergência do Atlântico Sul (ZCAS) (Kodama, 1992; Carvalho et al., 2002, 2004; Vera et al., 2006). A ZCAS modula a intensidade e localização da chuva de verão e varia significativamente em termos de intensidade e extensão geográfica em múltiplas escalas de tempo (Paegle e Mo, 2002; Carvalho et al., 2004). A posição e intensidade da ZCAS são fortemente influenciadas pelo regime de ventos de baixos níveis os quais trazem ar quente e úmido do noroeste e ar frio e seco do sudeste (Lenters e Cook, 1999). A fase de decaimento da monção começa quando a convecção muda gradualmente para o norte na direção do equador acompanhando a diminuição do aquecimento solar na América do Sul subtropical.

Comparado ao sistema de monção do leste da Ásia que é o mais conhecido, o SMAS é mais fraco e tem um tempo de vida menor. O motivo é o tamanho menor e a menor altitude do Platô do Altiplano (comparado ao Tibetano) e a localização em uma latitude menor o que reduz a eficiência da geração de vorticidade por divergência horizontal (Zhou e Lau, 1998). No entanto, o SMAS é responsável por mais de $80 \%$ da precipitação média anual no centro de atividade da ZCAS em torno de $23^{\circ} \mathrm{S}$, sobre a cidade do Rio de Janeiro e por 50\% do total de precipitação de verão ao longo da costa ao sul de $25^{\circ} \mathrm{S}$ (Garreaud e Wallace, 1998; Cruz Jr. et al., 2006).

\subsection{OCEANOGRAFIA}

\subsubsection{Propriedades das águas superficiais}

$\mathrm{Na}$ área de estudo, a média anual da temperatura superficial do mar (TSM) é de $24^{\circ} \mathrm{C}$ com variações sazonais de $4^{\circ} \mathrm{C}$ (Fig. 2.5) (Levitus e Boyer, 1994), o que está de acordo com o esperado segundo a distribuição aproximadamente zonal da TSM. A advecção de águas quentes pela Corrente do Brasil no Atlântico Sul ocidental e a ressurgência ao longo da costa da Namíbia no lado oriental são responsáveis pelo contraste leste-oeste de TSM nos subtrópicos. 
(a)

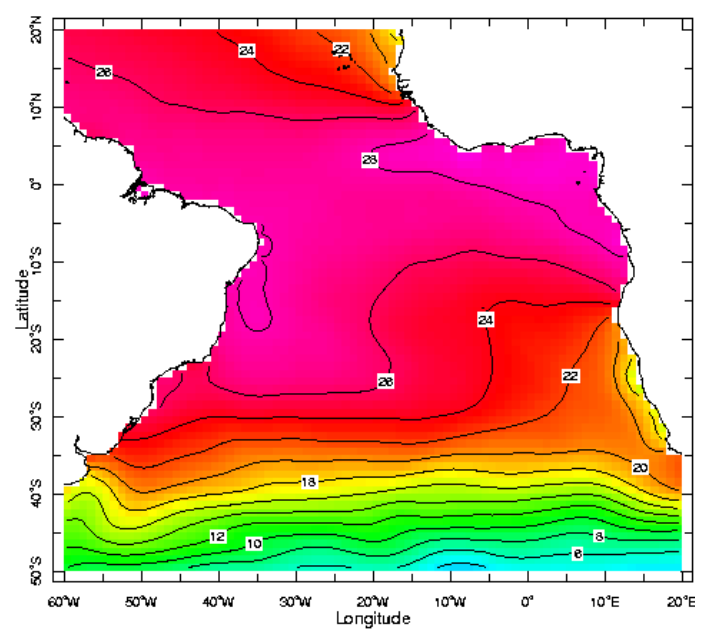

(c)

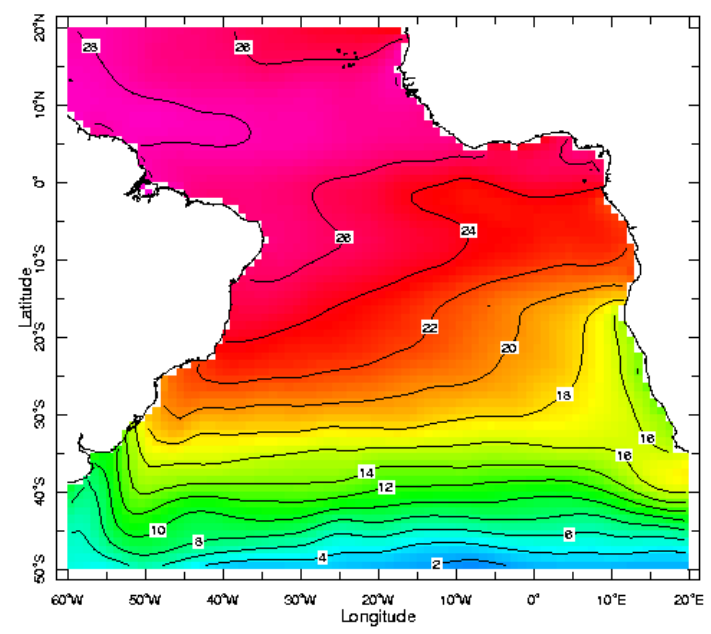

(b)

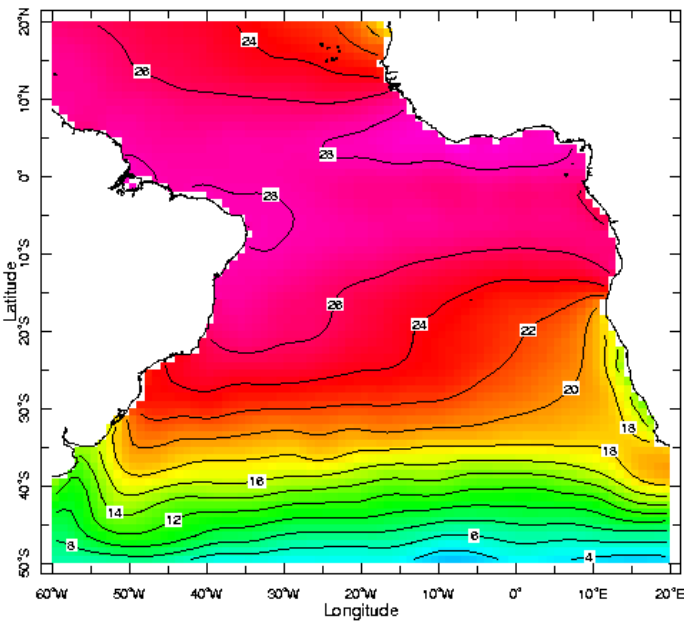

(d)

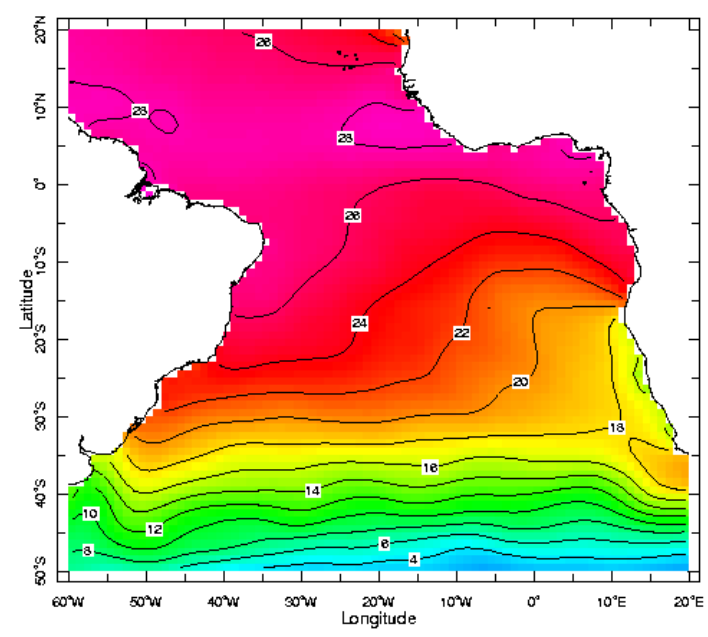

$15^{\circ} \mathrm{C} \quad 20^{\circ} \mathrm{C}$

$25^{2} \mathrm{C}$ $30^{\circ} \mathrm{C}$

Temperatura

Fig. 2.5. Variação sazonal da TSM $\left({ }^{\circ} \mathrm{C}\right)$ de acordo com o World Ocean Atlas 2005 (WOA05, Locarnini et al., 2006): (a) janeiro a março, (b) abril a junho, (c) julho a setembro e (d) outubro a dezembro. Contornos a cada $2^{\circ} \mathrm{C}$.

A média anual de salinidade superficial do mar (SSM) na área de estudo é de 36,5 (Levitus e Boyer, 1994) (Fig. 2.6). Olhando no contexto global, a salinidade das águas superficiais segue, basicamente, uma distribuição zonal, acompanhando as variações latitudinais no balanço entre precipitação e evaporação. Desvios deste padrão ocorrem devido à influência dos continentes e das correntes oceânicas e atmosféricas (Fig. 2.7), mas, de maneira geral, existe um mínimo pouco ao norte do equador, valores máximos em torno dos $25^{\circ}$ de latitude em ambos os hemisférios e, finalmente, existe 
uma progressiva diminuição da salinidade em direção às altas latitudes. O mínimo de baixas latitudes está associado à elevada precipitação na ZCIT e os máximos coincidem com a região afetada pelos ventos alísios, onde a evaporação excede a precipitação.

(a)

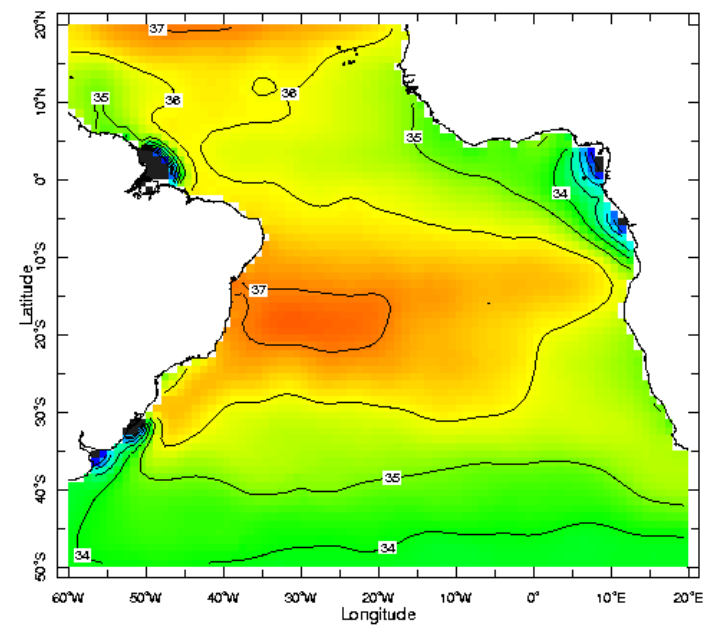

(c)

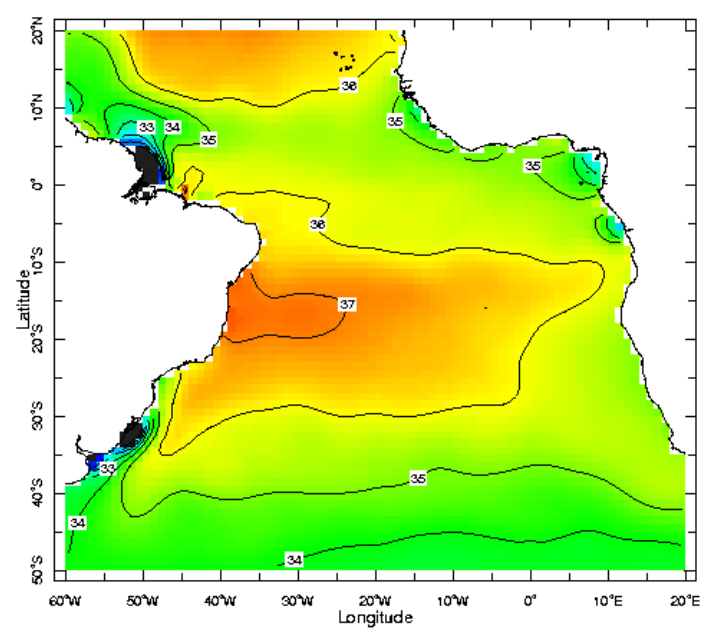

(b)

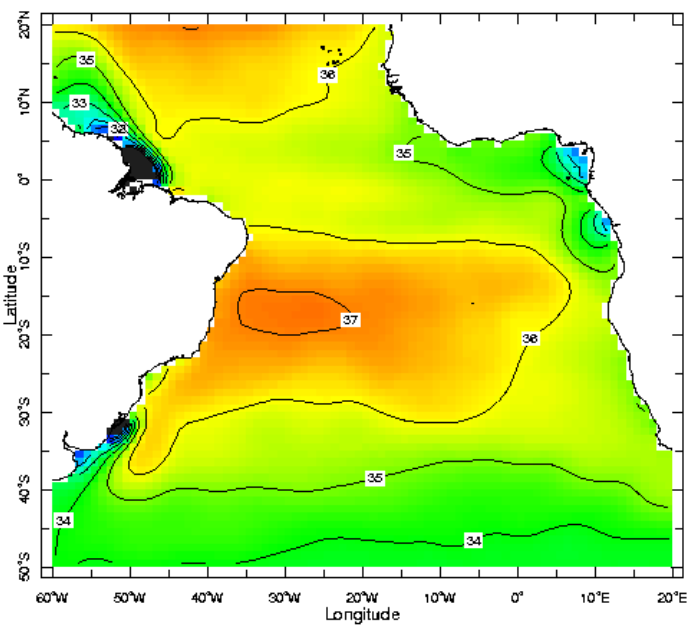

(d)

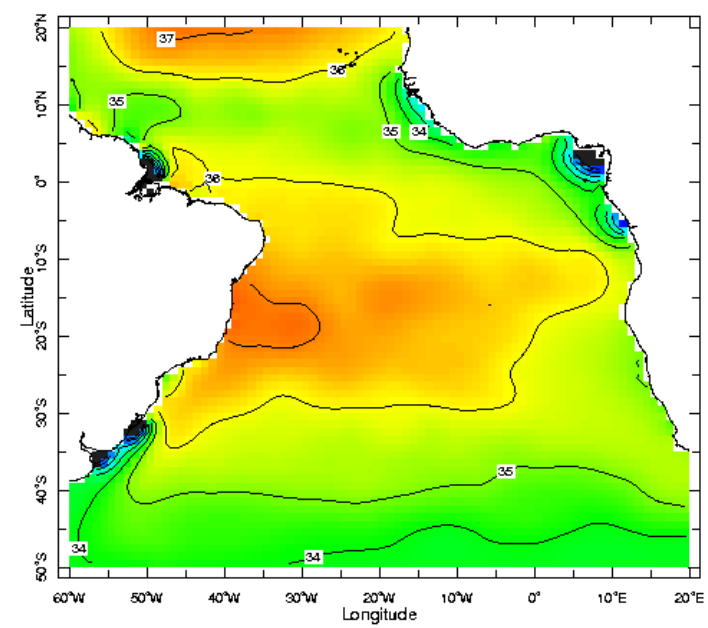

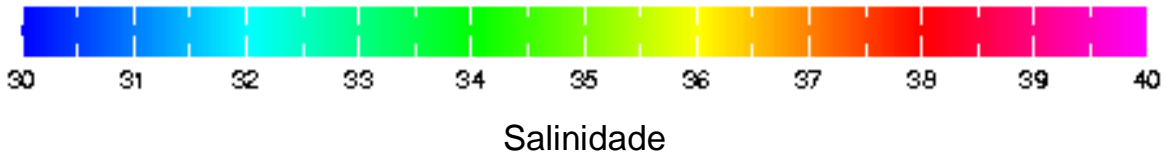

Fig. 2.6. Variação sazonal da SSM de acordo com o WOA05 (Antonov, 2006): (a) janeiro a março, (b) abril a junho, (c) julho a setembro e (d) outubro a dezembro. Contornos a cada duas unidades.

Estimativas baseadas em dados climatológicos e em modelos gerais de circulação atmosférica indicam que, no oceano Atlântico, o volume de água evaporado supera a água que entra no oceano via aportes de rios e precipitação (Broecker, 1989). Nem mesmo o deságüe de grandes rios que drenam extensas bacias hidrográficas como, por exemplo, os rios Mississipi, Orinoco, Amazonas, Paraná, Congo e Níger é capaz de 
compensar os altos níveis de evaporação (Tomczak e Godfrey, 2001). O sal excedente é o que garante a produção da Água Profunda do Atlântico Norte (APAN) e, portanto, o funcionamento do cinturão de transporte termohalino (o "global conveyor belt") (Broecker, 1989). Não fosse pela troca de águas salgadas do Atlântico por águas menos salgadas do Pacífico via circulação termohalina, a salinidade de todo o oceano Atlântico aumentaria em torno de um grama por litro a cada milênio (Broecker, 1997b).

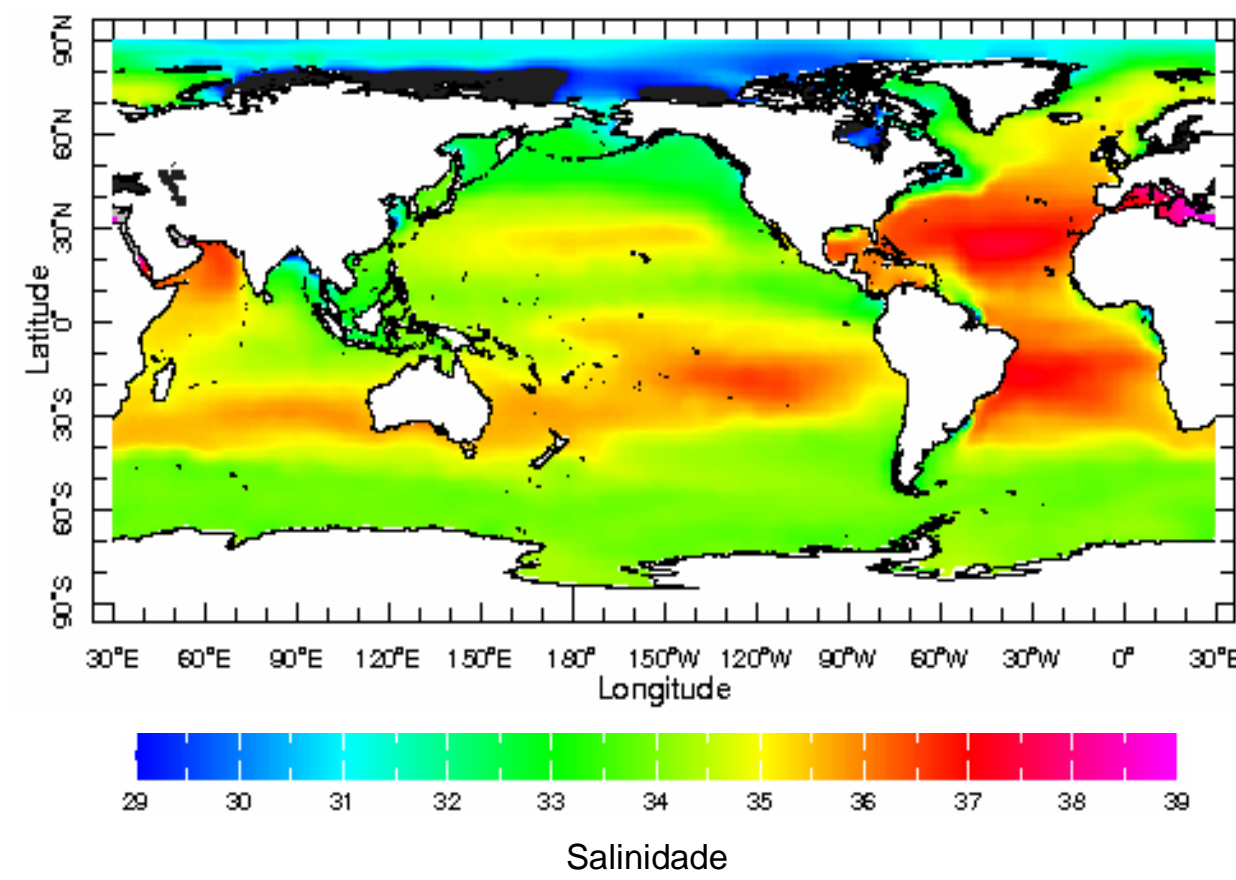

Fig. 2.7. Média anual da SSM no oceano moderno segundo dados do WOA05 (Antonov, 2006).

Como conseqüência do forte balanço positivo de evaporação menos precipitação, o oceano Atlântico é hoje, significativamente mais salgado que as demais bacias oceânicas (Fig. 2.7). O contraste de salinidade entre o Atlântico e o Pacífico é considerado um dos fatores cruciais para o funcionamento e manutenção da circulação termohalina global tal como ela é hoje (Seidov e Haupt, 2002; 2003). A atual configuração geográfica da América Central contribui para manter este contraste, constituindo uma barreira física entre os oceanos Atlântico e Pacífico, mas sendo o suficientemente baixa como para permitir a exportação de vapor d'água do Atlântico para o Pacífico (Tomczak e Godfrey, 2001). O contraste de salinidade entre os oceanos Atlântico e Pacífico disputa com o as perturbações no fluxo de água doce em altas 
latitudes, especialmente no Atlântico Norte, o papel mais importante na manutenção da circulação termohalina global, tal como ela é hoje (Seidov e Haupt, 2003).

\subsubsection{Massas d'água e circulação}

Sobre a plataforma continental, principalmente a interna, ocorre a Água Costeira (AC), a qual constitui uma mistura das águas oceânicas com águas oriundas da drenagem continental. Conforme mencionado na seção 2.1 , no continente adjacente à região de estudo existem apenas pequenos estuários que contribuem com água doce. Eventualmente, no entanto, águas frias $\left(14-17^{\circ} \mathrm{C}\right)$ e pouco salinas (salinidade entre $33 \mathrm{e}$ 34) provenientes do Rio da Prata invadem a plataforma na área do Embaiamento de São Paulo (Campos et al., 1999). Dados históricos e estudos de modelagem (Pimenta et al., 2005; Piola et al, 2005) sugerem que o grau de penetração da pluma do Rio da Prata depende mais da influência do vento (especificamente da componente da tensão de cisalhamento do vento ao longo da costa) do que da vazão do rio.

Mar afora, a corrente do Brasil transporta em superfície Água Tropical (AT) quente $\left(>18^{\circ} \mathrm{C}\right)$ e salina (>36) e na picnoclina a Água Central do Atlântico Sul (ACAS) com temperaturas entre 6 e $20^{\circ} \mathrm{C}$ e salinidade entre 34,6 e 36 (Silveira et al., 2000). A $\mathrm{CB}$ corresponde à corrente de contorno oeste do giro subtropical do Atlântico Sul e tem a sua origem na bifurcação do ramo sul da Corrente Sul Equatorial (CSE) a qual se divide em CB para o sul e Corrente Norte do Brasil (CNB) para o norte. A latitude de bifurcação muda em função da profundidade, sendo superficialmente mais ao norte e migrando para o sul com o aumento da profundidade (Rodrigues et al., 2006). Para o nível da AT, a bifurcação ocorre entre as latitudes de 9 e $15^{\circ} \mathrm{S}$ migrando para $25^{\circ} \mathrm{S}$ no nível da ACAS (Cirano et al., 2006).

Quando comparada com outras correntes de contorno oeste, a CB é relativamente fraca já que boa parte do transporte no ramo norte do giro subtropical do Atlântico Sul é perdido para o hemisfério norte e para as contracorrentes equatoriais (Stramma et al. 1990). Ao sul de $24^{\circ} \mathrm{S}$, a corrente do Brasil se intensifica a uma taxa de $5 \%$ a cada $100 \mathrm{~km}$ (Peterson e Stramma, 1991). Parte desta intensificação pode estar relacionada a uma célula de recirculação (Stramma, 1989). O afastamento da plataforma ocorre entre 33 e $38^{\circ} \mathrm{S}$ onde forma uma frente na convergência com a corrente das Malvinas, um ramo da Corrente Circumpolar Antártica que flui para o norte após atravessar a Passagem de Drake. É na subducção da Confluência Brasil-Malvinas que é 
formada parte da ACAS. Outra parte importante da ACAS é formada no Oceano Índico e trazida para o oceano Atlântico através dos anéis da corrente das Agulhas (Tomczak e Godfrey, 2001).

A Fig. 2.8 mostra esquematicamente a circulação superficial do Atlântico Sul de acordo com Peterson e Stramma (1991). Além da CB e da CSE, as demais correntes que fazem parte do giro subtropical são a Corrente de Benguela $(\mathrm{CBe})$ no leste e do Atlântico Sul (CAS) no extremo sul. A CAS flui para o leste, mas separada da Corrente Circumpolar Antártica pela frente subtropical. A CBe constitui a corrente de contorno leste do giro subtropical do Atlântico Sul. Esta tem origem na latitude do Cabo da Boa Esperança como um fluxo para norte que depois muda para o noroeste se afastando do continente africano em torno de $30^{\circ} \mathrm{S}$. Além de ser alimentada pela CAS, a CBe também recebe águas da Corrente das Agulhas e Águas Subantárticas superficiais provindas de perturbações na frente subtropical (Peterson e Stramma, 1991). Os ventos predominantes de $\mathrm{S}$ e $\mathrm{SE}$ na região da $\mathrm{CBe}$ promovem a ressurgência costeira de águas frias e ricas em nutrientes.

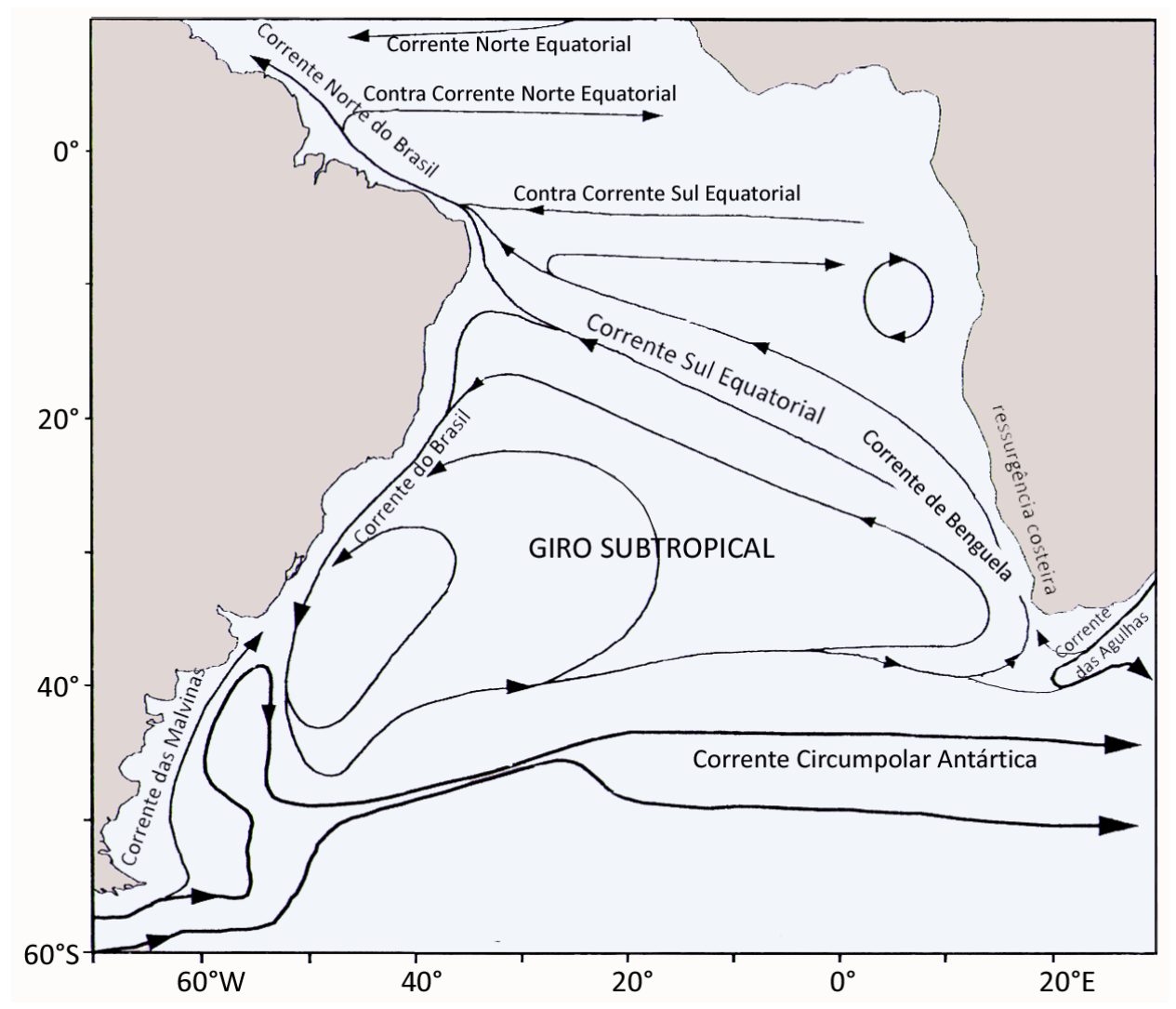

Fig. 2.8. Esquema geral de circulação superficial do Atlântico Sul, de acordo com Peterson e Stramma (1991). 
Logo abaixo da ACAS, encontra-se a Água Intermediária Antártica (AIA), a qual é formada na Convergência Antártica e se caracteriza por um mínimo de salinidade. De acordo com Cirano et al. (2006), a bifurcação Norte-Sul no nível da AIA ocorre em torno de $25-30^{\circ} \mathrm{S}$, ou seja, próximo ao local dos testemunhos analisados nesta tese. Na profundidade onde foi coletado o testemunho KF-02, a AIA é atualmente a massa d'água presente no fundo. Em profundidades maiores do Atlântico sudoeste, ainda ocorrem as massas de água profundas oriundas do Norte (Água Profunda do Atlântico Norte ou APAN) e do Sul (Água Circumpolar Superior ou ACS e Água Antártica de Fundo ou AAF). A interface entre a APAN e a AAF, em torno de 4100$4200 \mathrm{~m}$ de profundidade, define a atual lisoclina (Frenz e Henrich, 2007).

A Fig. 2.9 apresenta um diagrama T-S característico do Atlântico sudoeste em latitudes próximas à área de estudo. A ACAS aparece praticamente como uma linha estendendo-se desde altas temperaturas e salinidades até baixas temperaturas e salinidades. A AIA se destaca pelo mínimo de salinidade.

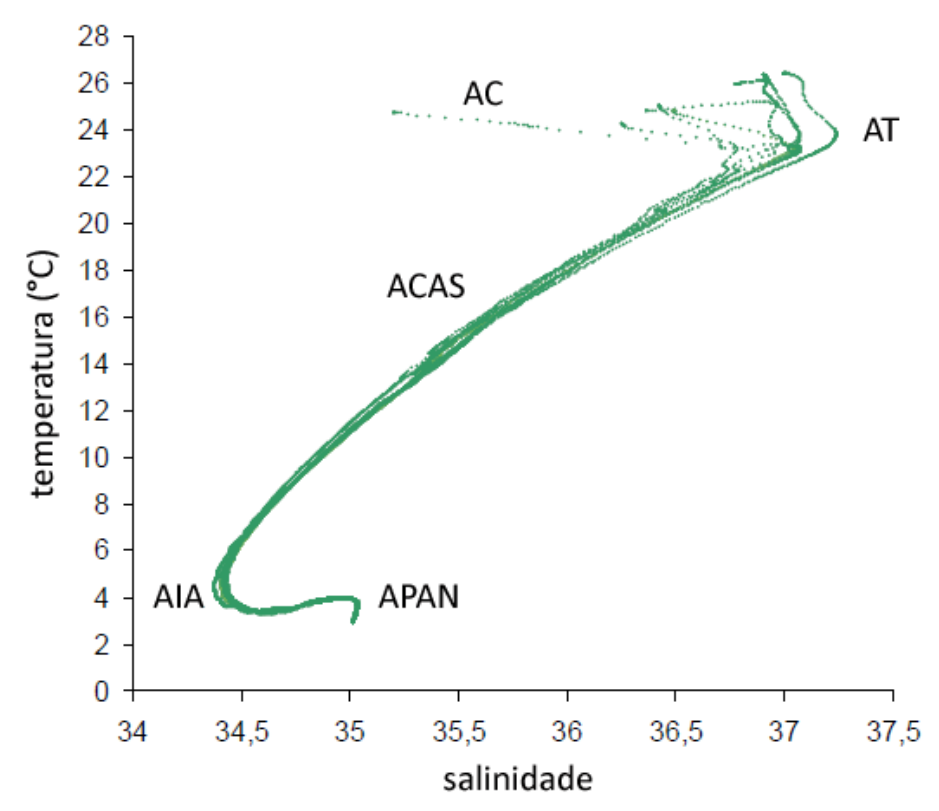

Fig. 2.9. Diagrama T-S espalhado característico da região de estudo. Dados coletados no verão de 2002 entre Cabo Frio e São Sebastião. Modificado de Sorano (2006).

Em termos de transporte de calor, o oceano Atlântico Sul se diferencia das demais bacias oceânicas por ser o único onde o transporte ocorre na direção do equador. A circulação superficial regida pelo vento atua de acordo com o esperado, transportando calor em direção aos pólos através da corrente do Brasil, mas a circulação termohalina 
determina um transporte líquido de calor para norte através das águas de termoclina e águas intermediárias (de Ruijter et al., 1999). O Atlântico sul recebe águas quentes provenientes do oceano Indico através da corrente das Agulhas, pela liberação intermitente de enormes anéis. Acredita-se que esta conexão seja um fator chave na manutenção da circulação oceânica global (por ex. de Ruijter et al., 1999; Weijer et al., 2002).

\subsubsection{Variabilidade sazonal e interanual}

A variabilidade climática existe em todas as escalas de tempo e os processos climáticos estão intimamente interligados de tal maneira que, para compreender a variabilidade em uma determinada escala de tempo, é necessária uma certa compreensão do todo (Huybers e Curry, 2006).

O ciclo sazonal das correntes superficiais reflete a resposta do oceano às variações no regime de vento e à migração da ZCIT (Stramma e Schott, 1999). A bifurcação da CSE e a intensidade relativa da CB e CNB são um bom exemplo disto. A intensidade máxima da CB ocorre durante o verão austral quando a bifurcação ocorre mais próximo do equador (Rodrigues et al., 2006) e devido à posição mais meridional da ZCIT os ventos alísios de NE estão mais intensos. Nesta situação, a CNB é enfraquecida e conseqüentemente a CB é fortalecida (Johns et al., 1998; Kim e Schneider, 2003). O fortalecimento da CB resulta em um deslocamento para o sul da Confluência Brasil-Malvinas (Matano et al.,1993; Goñi e Wainer, 2001). A situação oposta ocorre durante o inverno austral, quando a bifurcação da SEC ocorre mais ao sul, a ZCIT se encontra mais ao norte e os ventos alísios de SE penetram no hemisfério norte fortalecendo a CNB em detrimento da $\mathrm{CB}$.

$\mathrm{Na}$ escala interanual, a fonte mais potente de variabilidade climática é o fenômeno El Niño - Oscilação Sul (ENOS) (Tudhope et al., 2001). A fase positiva, o El Niño, ocorre quando há um aquecimento das águas superficiais no Pacífico leste equatorial e a fase negativa, La Niña, quando há um resfriamento. Apesar do fenômeno iniciar no Pacífico, ele desencadeia uma série de anomalias climáticas que se propagam globalmente. Sobre a América do Sul, as anomalias estão associadas principalmente ao deslocamento da célula de Walker, ao fortalecimento do jato subtropical e a um possível trem de ondas que se estende desde o Pacífico até o sul da América do Sul (Cavalcanti, 1996). No Brasil, o El Niño se manifesta principalmente como anomalias de 
precipitação positivas no Sul e negativas no Nordeste (Cavalcanti, 1996). Na região sudeste, a primavera em anos de El Niño se caracteriza por anomalias positivas de temperatura (Grimm, 2003).

Um fenômeno semelhante ao El Niño do Pacífico ocorre também no Atlântico, porém com menor intensidade e maior freqüência (Zebiak, 1993). Este é conhecido como o modo Equatorial ou Cold Tongue. Este modo de variabilidade está fortemente relacionado ao ciclo sazonal, apresentando uma amplitude máxima durante o verão boreal quando costumam aparecer águas frias ao longo do Atlântico leste equatorial (Ruiz-Barradas et al., 2000). Durante a fase positiva, as águas frias estão ausentes, a TSM é elevada no Atlântico leste equatorial, os ventos alísios no Atlântico oeste equatorial são enfraquecidos e a convecção aumenta ao sul da posição normal da ZCIT (Ruiz-Barradas et al., 2000).

Outro modo de variabilidade oceano-atmosfera que se sobrepõe às variações sazonais no Atlântico tropical é o de Gradiente Meridional ou Dipolo. Este modo caracteriza-se por um padrão de anomalias de TSM de sinal oposto ao norte e sul do Atlântico tropical. A fase positiva (negativa) ocorre quando há uma anomalia positiva (negativa) de TSM no norte e negativa (positiva) no Sul. Estas anomalias de TSM afetam significativamente a posição e intensidade da ZCIT (Stramma e Schott, 1999). O resfriamento (aquecimento) anômalo das águas superficiais ocorre associado a uma elevação (diminuição) da pressão ao nível do mar e conseqüente intensificação (enfraquecimento) da Alta Subtropical que se reflete em uma intensificação (relaxamento) dos ventos alísios (Souza e Nobre, 1998). O modo Dipolo também está relacionado ao ciclo sazonal, sendo mais intenso na primavera boreal (Ruiz-Barradas et al., 2000).

\subsubsection{Produtividade}

Os principais fatores que determinam a produção primária são a disponibilidade de nutrientes e luz. Na área de estudo, a combinação destes fatores não é favorável à produção, já que a AT, que ocupa a maior parte da zona eufótica, tem características oligotróficas. Já a ACAS se apresenta como uma água rica em nutrientes, mas devido à estabilidade da termoclina permanente, os nutrientes costumam ficar trapeados em subsuperfície (Lopes et al., 2006). Com isto, os níveis de nutrientes na zona eufótica acabam sendo baixos e geralmente controlados por processos regenerativos (Metzler et 
al., 1997). Alguns dos processos físicos que promovem a ruptura da termoclina, a elevação da ACAS e, portanto, uma fertilização da zona eufótica são a ressurgência costeira, os vórtices ciclônicos e ondas internas (Gaeta e Brandini, 2006).

A predominância de ventos de $\mathrm{NE}$, especialmente no verão, favorece a ressurgência costeira próximo à região de Cabo Frio $\left(22^{\circ} \mathrm{S}\right)$ (Castro e Miranda, 1998). Devido ao transporte de Ekman, os ventos de NE favorecem o afastamento das águas de superfície para o mar aberto e a ascensão da ACAS. Além da ressurgência costeira, vórtices ciclônicos da $\mathrm{CB}$ são responsáveis por um regime de ressurgência de plataforma relativamente forte o qual bombeia grandes quantidades de ACAS para o talude superior e para a plataforma continental (Campos et al., 2000). A formação de vórtices é favorecida pela mudança de orientação da costa do sentido norte-sul para o sentido praticamente leste-oeste em torno de Cabo Frio, associada aos ventos de nordeste e a um meandramento importante da corrente do Brasil (Campos et al., 1995) (Fig. 2.10).

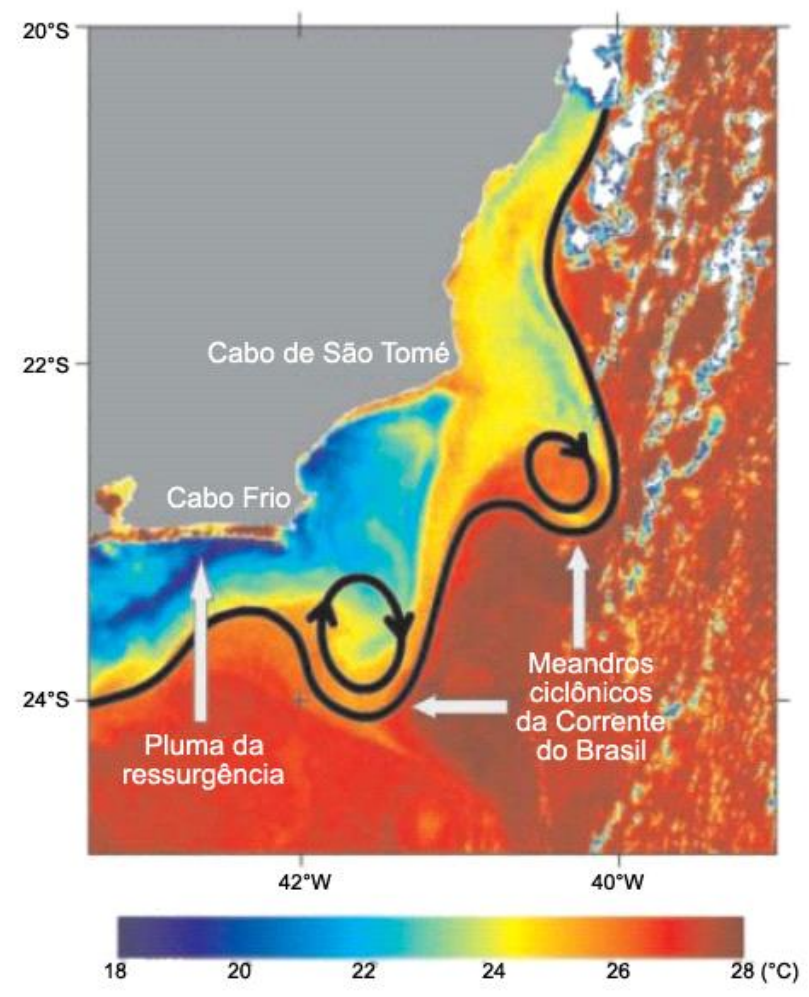

Fig. 2.10. Imagem de AVHRR mostrando a ressurgência costeira de Cabo Frio e o meandramento da CB (Mahiques et al., 2005). 
Enquanto a ressurgência costeira é um fenômeno mais importante no verão, a ressurgência associada aos vórtices da CB ocorre ao longo do ano todo (Campos et al., 2000). Quando ocorrem simultaneamente há uma interação positiva já que a ressurgência induzida pelo meandramento da CB leva a ACAS para profundidades menores onde fica sujeita à ação dos ventos de NE favoráveis à ressurgência (Castelão et al., 2004). A Fig. 2.11 mostra esquematicamente o funcionamento da ressurgência.
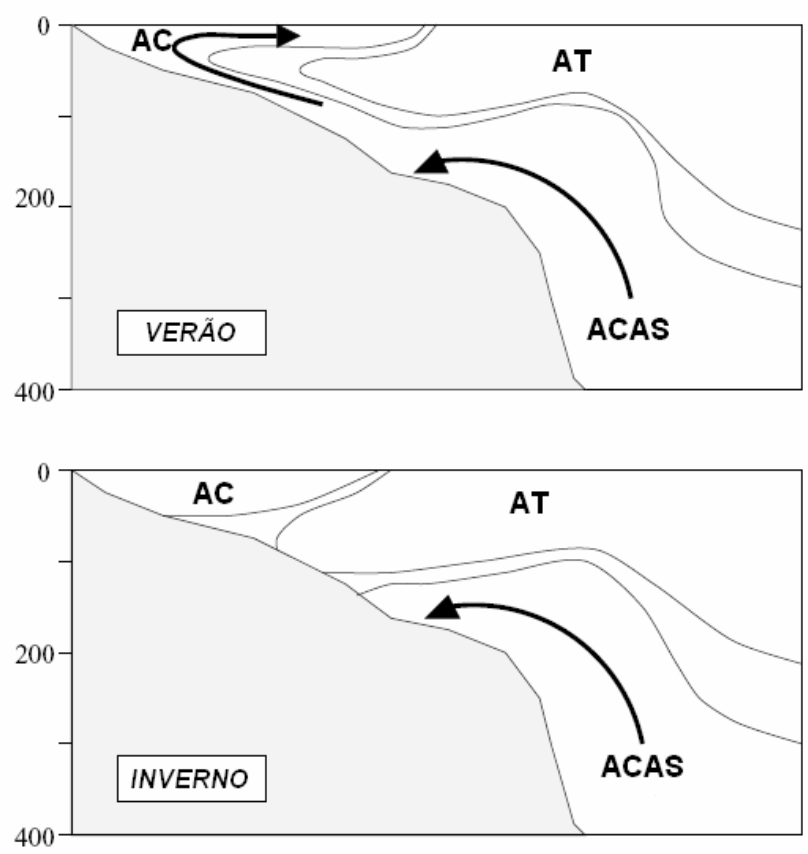

Fig. 2.11. Esquema do efeito combinado da ressurgência costeira associada à ação dos ventos de $\mathrm{NE}$ e a ressurgência induzida pela ação de meandros da $\mathrm{CB}$ ( $\mathrm{AC}=$ Água Costeira; $\mathrm{AT}=$ Água Tropical e ACAS= Água Central do Atlântico Sul) (Campos et al., 2000).

Observando o Atlântico Sul ocidental como um todo, a região de alta produtividade mais próxima da área de estudo é a da confluência Brasil-Malvinas aproximadamente em torno de $38^{\circ} \mathrm{S}$. A intensa produtividade na área da confluência é evidenciada pelos altos níveis de clorofila (Garcia et al., 2004; Gonzalez-Silveira et al., 2006). É nesta região da Confluência que é formada parte da ACAS. A pluma do Rio da Prata também está relacionada a uma maior produtividade (Gonzalez-Silveira, et al., 2006). Junto com a Lagoa dos Patos $\left(32^{\circ} \mathrm{S}\right)$, o Rio da Prata $\left(35^{\circ} \mathrm{S}\right)$ é responsável por uma importante fonte de nutrientes para o oceano no Atlântico Sul ocidental. Em média, a pluma de baixa temperatura e baixa salinidade do Rio da Prata chega a $32^{\circ} \mathrm{S}$ na primavera e verão e $28^{\circ} \mathrm{S}$ no inverno (Piola et al., 2000), mas com ventos favoráveis, a 
pluma já foi registrada até a latitude $23^{\circ} \mathrm{S}$ (Campos et al., 1999) (Fig. 2.12). De acordo com Gaeta e Brandini (2006), a intrusão da pluma provavelmente seja o principal mecanismo de enriquecimento em larga escala da zona eufótica de águas da plataforma com nutrientes novos, porém, atualmente este aporte é importante apenas em baixas profundidades.

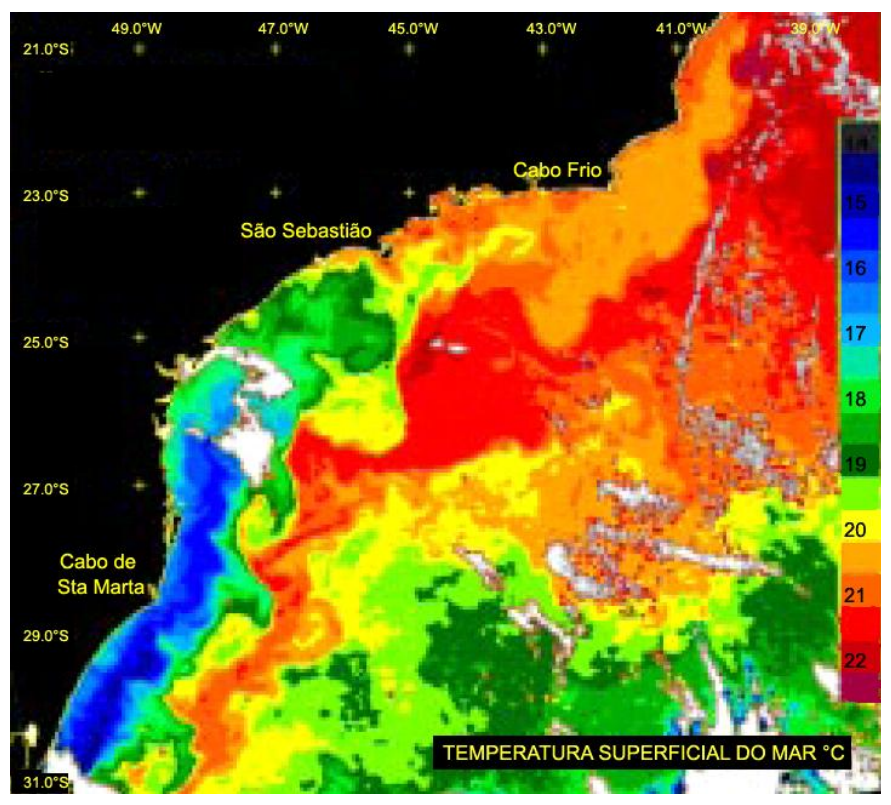

Fig. 2.12. Estimativa de TSM de acordo com imagem de AVHRR/NOAA durante julho de 1993. Modificado de Campos et al. (1999). A cor azul indica a advecção de águas frias provenientes de sudoeste. 


\section{CONTEXTO PALEOCLIMÁTICO E PALEOCEANOGRÁFiCO DESDE O ÚLTIMO MÁXIMO GLACIAL DE ACORDO COM ESTUDOS PRETÉRITOS}

No final do Quaternário, a Terra testemunhou mudanças climáticas extremas, desde o Último Máximo Glacial (UMG) até o atual interglacial. Neste capítulo é apresentado um resumo dos conhecimentos sobre o clima da Terra durante o UMG (seção 3.1.), a deglaciação (3.2) e o Holoceno (3.3).

\subsection{O ÚLTIMO MÁXIMO GLACIAL}

Antes de descrever o UMG é preciso definir quando aconteceu. O UMG corresponde ao intervalo de tempo mais recente em que as geleiras atingiram os seus maiores volumes durante a última glaciação. Uma vez que o gelo concentra o isótopo de oxigênio leve $\left({ }^{16} \mathrm{O}\right)$, a expansão das geleiras leva a uma concentração do isótopo pesado $\left({ }^{18} \mathrm{O}\right)$ nos oceanos. Desta forma, poderia se considerar o UMG como o período das maiores razões ${ }^{18} \mathrm{O} /{ }^{16} \mathrm{O}$ nos oceanos. No entanto, regionalmente existe uma série de outros fatores envolvidos na determinação da razão isotópica que podem mascarar as mudanças globais. De fato, os registros mostram que diferentes regiões atingiram valores isotópicos máximos em momentos distintos e, ao mesmo tempo, não há um sincronismo exato entre os registros de isótopos de oxigênio e de variações do nível do mar (Mix et al., 2001). Desta forma, deve se evitar considerar o UMG dentro de um registro simplesmente como o período de maiores razões ${ }^{18} \mathrm{O} /{ }^{16} \mathrm{O}$ ou como o período mais frio e deve se priorizar o uso da definição cronológica, baseada em datações absolutas.

Neste trabalho, segue-se a definição do UMG do Projeto EPILOG (Environmental Processes of the Ice age: Land, Oceans, Glaciers, Mix et al., 2001) por ser a mais consistente e mais utilizada hoje em dia. Os membros do EPILOG procuraram dentro do intervalo mais recente de máximo volume de gelo o maior intervalo cronológico ao longo do qual o clima global foi razoavelmente estável, evitando mudanças e transições bruscas como os eventos Heinrich e DansgaardOeschger. De acordo com dados de testemunhos de gelo e de variações do nível do mar, 
o UMG foi definido como o intervalo de 4 mil anos compreendido entre 19 e 23 mil anos AP ou 16,1 a $19,5{ }^{14} \mathrm{C}$ anos AP.

O UMG foi o ápice do último período glacial o qual teve início em torno de 116 mil anos AP. Variações climáticas registradas em testemunhos marinhos (por ex. Hays et al., 1976, Imbrie et al., 1984) e testemunhos de gelo (por ex.; Petit et al., 1999; EPICA Community Members, 2004) reforçam a hipótese de Milankovitch do controle astronômico das glaciações, segundo a qual as glaciações do Quaternário estão relacionadas às variações nos parâmetros orbitais da Terra, isto é, obliqüidade do eixo de rotação da Terra, excentricidade da órbita da Terra ao redor do Sol e a precessão dos equinócios. Globalmente, os parâmetros orbitais praticamente não interferem no total anual de radiação solar recebida pela Terra. O que muda é a distribuição sazonal e latitudinal desta radiação fundamentalmente por variações da obliqüidade (período de em torno de 41mil anos) e da precessão dos equinócios (períodos de 23 a 19 mil anos) (Berger, 1993). Acredita-se que o fator crucial para o início ou fim de uma glaciação seja a quantidade de radiação solar incidente nas altas latitudes do hemisfério norte durante o verão. Por debaixo de um determinado valor, o calor do verão seria insuficiente para derreter a neve acumulada no inverno anterior e isto provocaria o início do acúmulo de gelo. No entanto, apesar de constituírem o principal fator de variação, o clima do Quaternário não foi apenas o produto das variações orbitais, mas também de outras forçantes externas e internas ao próprio sistema climático (Imbrie, 1982).

Especificamente no UMG, importantes feedbacks envolvendo a expansão dos mantos de gelo com a conseqüente mudança na reflectividade, alterações na circulação termohalina e, conseqüentemente, no transporte de calor e mudanças na concentração dos gases de efeito estufa agiram amplificando a forçante orbital a qual, considerada isoladamente, é relativamente fraca (Lorius et al., 1990). No caso da concentração de gases de efeito estufa, esta era consideravelmente menor no UMG do que os valores do fim do Holoceno (Fig.3.1). Por exemplo, a concentração de $\mathrm{CO}_{2}$ atmosférico passou de em torno de 180-200ppm no UMG para valores pré-industriais de 280ppm (Monnin et al., 2001). 

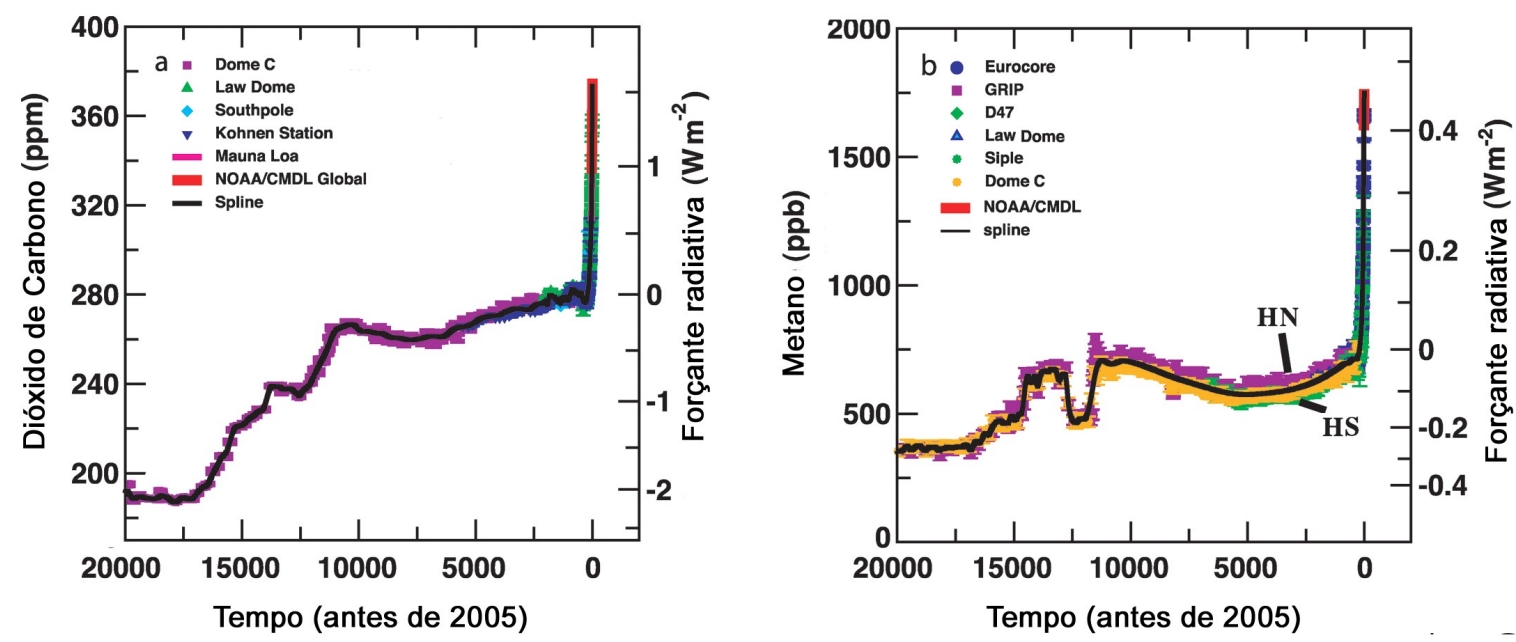

Fig. 3.1. Variação da concentração e forçante radiativa do dióxido de carbono (esquerda) e metano (direita) para os últimos 20 mil anos de acordo com dados de testemunhos de gelo da Antártida e Groenlândia e, mais recentemente, medições atmosféricas (Jansen et al., 2007) (HN $=$ Hemisfério Norte, HS = Hemisfério Sul).

Um dos exemplos mais claros de feedback positivo é o do albedo. Como o albedo do gelo é muito elevado (a maior parte da radiação incidente é refletida), à medida que os mantos de gelo se expandiam, a temperatura do ar diminuía favorecendo ainda mais a expansão do gelo. Como resultado, durante o UMG, o gelo cobria grande parte da América do Norte e da Europa. A atmosfera mais fria também teria provocado a descida de em torno de $1 \mathrm{~km}$ das linhas de neve (Broecker e Denton, 1990).

O acúmulo da água na forma de grandes mantos de gelo causou um significativo rebaixamento do nível do mar. De acordo com as estimativas mais recentes de Peltier e Fairbanks (2006) o rebaixamento teria sido de em torno de $120 \mathrm{~m}$ o que significa que grande parte do que hoje é plataforma continental teria ficado exposto. Da mesma maneira, um rebaixamento do nível do mar de $120 \mathrm{~m}$ corresponde a uma diminuição do volume dos oceanos - e conseqüente aumento de salinidade - de em torno de 3,16\% (Duplessy et al., 2001).

As modificações climáticas do UMG também se refletiram fortemente na distribuição da vegetação. De acordo com Prentice et al., (2000), existem evidências de uma expansão dos biomas tundra e estepe, uma compressão da área de florestas boreais e uma redução da floresta tropical africana. De acordo com os autores, estas mudanças estariam de acordo com uma resposta a um aumento da aridez e diminuição da temperatura. Já, na região amazônica, apesar dos modelos sugerirem um clima frio e seco (Hostetler e Mix, 1999), a hipótese de aridez durante o glacial não se aplicaria, já 
que as evidências apontam para uma cobertura da floresta sem fragmentações, durante todo o Pleistoceno (Colinvaux et al., 2000; Colinvaux e de Oliveira, 2001) embora com mudanças na composição da flora (Bush et al., 2004).

Os dados palinológicos devem ser analisados com cautela, já que certas gramíneas (plantas C4) são mais eficientes do que outras (plantas $\mathrm{C} 3$ ) no uso do $\mathrm{CO}_{2}$ (Ehleringer et al., 1997). Isto significa que, devido às mudanças na concentração de $\mathrm{CO}_{2}$, não existem verdadeiros análogos modernos para os dados de pólen do UMG (Crowley, 2000) e as variações na abundância de certas espécies, não pode ser atribuída apenas às variáveis climáticas (precipitação e temperatura) já que elas constituem uma resposta complexa ao conjunto de variáveis temperatura, precipitação, sazonalidade e concentração de $\mathrm{CO}_{2}$ (Huang et al., 2001; Mayle, et al., 2004). De acordo com Prentice et al. (2000), no entanto, o efeito da redução na concentração de $\mathrm{CO}_{2}$ atmosférico não invalida as mudanças na precipitação atmosférica como a principal causa das mudanças dos biomas no UMG. Os autores argumentam que as reduções na precipitação são um fenômeno comum às simulações do clima do UMG das latitudes baixas e médias (por ex. Pinot et al., 1999).

Um aumento da aridez e redução da cobertura vegetal seriam os responsáveis pelo aumento geral da poeira atmosférica durante o UMG (Mahowald et al., 1999). Registros sugerem um aumento na deposição de poeira no UMG em relação ao interglacial de 2 a 20 vezes em testemunhos de gelo de altas latitudes, de até cinco vezes em registros marinhos de latitudes baixas a médias e uma redução no fluxo de poeira em algumas regiões equatoriais (Kohfeld e Harrison, 2001). De acordo com os estudos de modelagem de Mahowald et al. (1999), o aumento da poeira depositada em latitudes médias no UMG pode ser parcialmente explicado por mudanças na circulação atmosférica.

Os fortes gradientes de temperatura entre os pólos e o equador e uma compressão da zona de convergência tropical devido à expansão dos mantos de gelo e da área dos continentes devem ter modificado os gradientes de pressão e assim, devem ter aumentado a intensidade dos ventos alísios (Kim e Schneider, 2003). No Atlântico, existem evidências de ventos alísios de sul ainda mais fortes do que os de norte (Pflaumann et al., 2003). 


\subsubsection{Os oceanos no UMG}

No oceano, existem evidências de importantes mudanças na CTH. No Atlântico Norte, ao invés da formação da APAN, teria se formado uma água intermediária (Água intermediária do Atlântico Norte Glacial) e o espaço atualmente ocupado pela APAN teria sido preenchido por águas profundas de origem antártica (Boyle e Keigwin, 1987; Duplessy et al., 1988; Costa, 2000, Oppo e Horowitz, 2000; Curry e Oppo, 2005; Marchitto e Broecker, 2006). O local de formação da Água Intermediária do Atlântico Norte teria sido mais ao sul do que o local atual de formação da APAN (Duplessy et al., 1988). O motivo da formação de uma massa d'água intermediária (menos densa) ao invés de uma água profunda parece estar relacionado à diminuição da salinidade superficial do Atlântico durante o UMG.

A maior parte do que se conhece hoje sobre os oceanos no passado, fundamentalmente em termos de distribuição das massas d'água, é baseado em proxies de paleonutrientes como a razão $\mathrm{Cd} / \mathrm{Ca}$ e $\delta^{13} \mathrm{C}$. A distribuição diferente de massas d'água no UMG foi interpretada por muito tempo como o resultado de um enfraquecimento da célula de revolvimento meridional do Atlântico (Meridional Overturning Circulation ou MOC). No entanto, estes proxies não proporcionam medidas de fluxos (LeGrand e Wunsch, 1995) e, apesar de praticamente existir um consenso na questão da distribuição das massas d'água no Atlântico durante o UMG, ainda permanece em debate a velocidade da CTH e, especificamente, da intensidade da MOC. Outro fator que contribui para aumentar as incertezas é a divergência entre as estimativas dos modelos disponíveis (por ex. Otto-Bliesner et al., 2007).

Uma circulação enfraquecida não combina com as fortes evidências de um sistema de ventos fortalecido durante o UMG, já que a intensidade da circulação geral dos oceanos é fundamentalmente função da intensidade dos ventos (Wunsch, 2003). Também, a presença de fortes gradientes das propriedades das massas d'água em profundidade indica que a advecção horizontal se manteve intensa em relação à mistura vertical, o que significa que a circulação no oceano profundo se manteve vigorosa durante o glacial (Curry e Oppo, 2005).

Um dos proxies de fluxo mais promissores, a razão ${ }^{231} \mathrm{~Pa} /{ }^{230} \mathrm{Th}$ (Yu et al., 1996; Marchal et al., 2000), está ajudando a esclarecer a questão da intensidade da circulação. $\mathrm{O}$ decaimento dos isótopos de Urânio na água produz ${ }^{231} \mathrm{~Pa} \mathrm{e}{ }^{230} \mathrm{Th}$. Enquanto o ${ }^{230} \mathrm{Th}$ rapidamente se liga às partículas em decantação e é acumulado nos sedimentos do 
Atlântico, o ${ }^{231} \mathrm{~Pa}$ é menos reativo e, portanto, permanece mais tempo sendo transportado na água. A maior parte do ${ }^{231} \mathrm{~Pa}$ acaba sendo capturado pelos elevados fluxos de partículas no Oceano Austral. Desta forma, a razão dos isótopos nos sedimentos funciona como um proxy da intensidade da MOC. De acordo com as estimativas mais recentes baseadas nesta razão isotópica (Gherardi et al., 2009), a célula meridional de transporte do Atlântico teria sido intensa, mas restrita a profundidades intermediárias e as águas profundas teriam sido renovadas mais lentamente do que hoje (Fig. 3.2). Com uma APAN substituída por uma água glacial intermediária e um maior fluxo para norte de água fria de origem antártica no Atlântico Norte, o fluxo de calor para o norte teria diminuído, mesmo mantendo uma circulação intensa o que demonstra a importância de se fazer a distinção entre fluxo de massa e fluxos de calor, sal (ou água doce) e nutrientes (Wunsch, 2003).

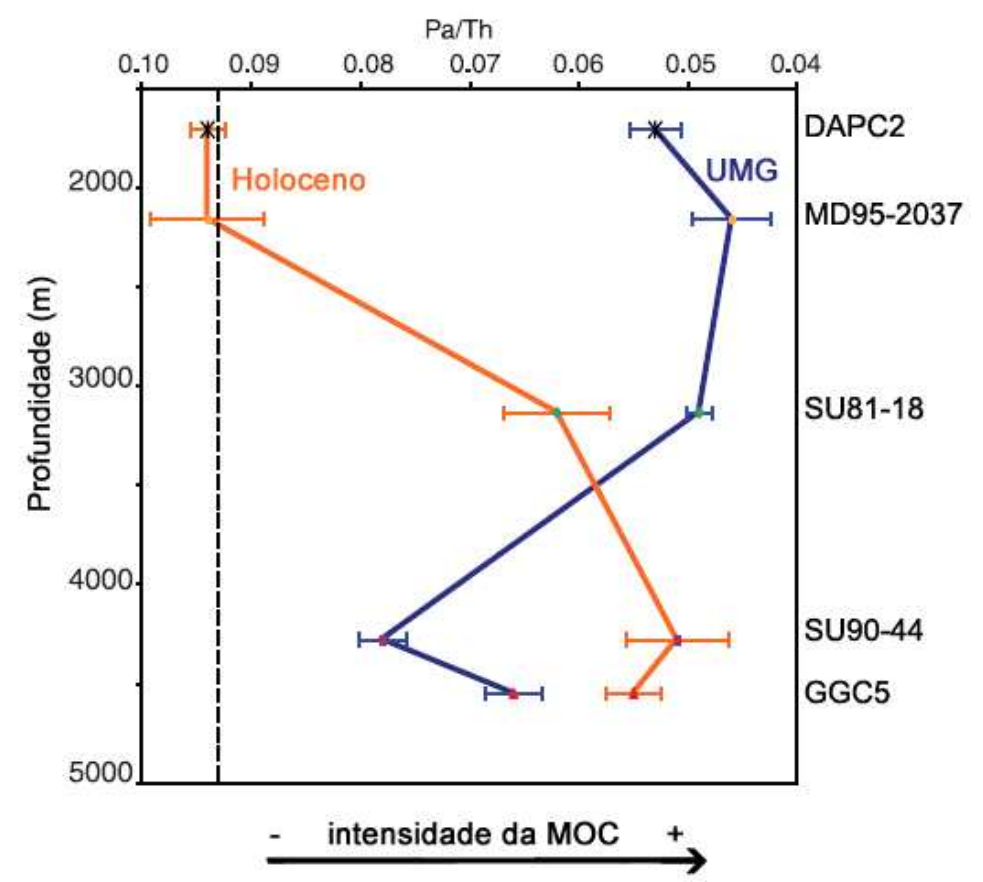

Fig. 3.2. Razão ${ }^{231} \mathrm{~Pa} /{ }^{230} \mathrm{Th}$ em amostras de sedimentos do UMG (linha azul) e Holoceno (linha laranja) de diferentes profundidades do Atlântico Norte de acordo com Gherardi et al. (2009). A escala da razão ${ }^{231} \mathrm{~Pa} /{ }^{230} \mathrm{Th}$ está invertida de maneira a mostrar uma MOC mais intensa do lado direito da figura. A linha vertical pontilhada indica a taxa de produção. Localização dos testemunhos: DAPC2- $58^{\circ} 58^{\prime} \mathrm{N}, 09^{\circ} 36^{\prime} \mathrm{W}, 1709 \mathrm{~m}$ de profundidade; MD95-2037: $37^{\circ} 05^{\prime} \mathrm{N}$, $32^{\circ} 01^{\prime} \mathrm{W}, 2150 \mathrm{~m}$ de profundidade; SU81-18- $37^{\circ} 46^{\prime} \mathrm{N}, 10^{\circ} 11^{\prime} \mathrm{W}, 3135 \mathrm{~m}$ de profundidade; SU90-44- $50^{\circ} 01^{\prime} \mathrm{N}, 17^{\circ} 06^{\prime} \mathrm{W}, 4279 \mathrm{~m}$ de profundidade e OCE326-GGC5- $33^{\circ} 42^{\prime} \mathrm{N}, 57^{\circ} 35^{\prime} \mathrm{W}$, $4550 \mathrm{~m}$ de profundidade. 


\subsubsection{A variação da TSM: do CLIMAP ao MARGO}

Uma das questões mais importantes e que tem sido alvo de maior debate em relação ao UMG é a amplitude das variações de TSM nos trópicos (Broecker, 1997a; Crowley, 2000). A primeira tentativa de reconstruir quantitativamente a TSM ao redor do globo durante o UMG foi do Projeto CLIMAP (Climate Long-Range Investigation, Mapping and Prediction) (CLIMAP, 1976). O projeto CLIMAP culminou com uma série de mapas com a reconstrução da superfície da Terra no UMG, com ênfase na TSM, mas incluindo também a distribuição do gelo na terra e no mar, assim como também a cobertura de vegetação e o albedo nos continentes (CLIMAP 1981). Um dos principais resultados do CLIMAP foi a descoberta de que as mudanças climáticas não tinham sido uniformes globalmente. Ao contrário, a magnitude e inclusive a direção das mudanças de temperatura tinha variado muito de uma região para outra com resfriamento significativo restrito às latitudes médias a altas, principalmente do hemisfério norte. Próximo ao equador, o resfriamento teria sido pequeno, mas o contraste sazonal teria aumentado.

Para as estimativas de TSMs, o CLIMAP se baseou na técnica de Função de Transferência (Imbrie e Kipp, 1971) em dados de assembléias de microfósseis. Esta técnica utiliza a análise de componentes principais para combinar, de maneira objetiva, as variáveis originais em combinações lineares (autovalores) que descrevem os principais padrões de variação em poucos componentes principais os quais são posteriormente comparados a diferentes parâmetros físicos - neste caso, temperatura por regressão múltipla.

As estimativas de TSM do CLIMAP para os trópicos pareciam difíceis de conciliar com outras estimativas baseadas em dados oceânicos e continentais tão variados como análises geoquímicas em corais (Beck et al., 1997; Guilderson et al., 1994), concentração de gases nobres em águas subterrâneas (Stute et al., 1995) e estudos palinológicos (Behling e Lichte 1997) os quais sugeriam um resfriamento muito maior, da ordem de $5^{\circ} \mathrm{C}$. A forte contradição entre as reconstruções do clima nos continentes e no oceano era evidenciada através do uso de modelos de circulação geral (por ex., Rind e Peteet, 1985; Pinot et al., 1999).

Em uma reavaliação crítica dos diferentes dados disponíveis, Crowley (2000) questionou a validade de alguns proxies e sugeriu que o resfriamento das águas tropicais durante o UMG teria sido mais intenso que o previsto pelo CLIMAP, mas menos 
intenso do que as demais estimativas que sugeriam um resfriamento de em torno de $5^{\circ} \mathrm{C}$. Parte da aparente contradição entre os dados oceânicos e terrestres é explicada pelo aumento das taxas de queda de temperatura com a altura (lapse rates) as quais eram maiores no UMG (Farrera et al., 1999).

A idéia de Crowley (2000) de um oceano tropical com TSMs não tão quentes quanto as propostas pelo CLIMAP para o UMG, mas mesmo assim com um resfriamento ainda modesto de em torno de 2 a $2,5^{\circ} \mathrm{C}$ foi posteriormente corroborada pelos resultados do Projeto GLAMAP (Glacial Atlantic Ocean Mapping, Sarnthein et al., 2003) para o Oceano Atlântico. Comparado ao CLIMAP, o GLAMAP se baseou em uma definição cronológica e em um controle de idade mais preciso para definir as amostras do UMG, em um aprimoramento das técnicas de função de transferência e em uma base de dados de calibração mais precisa (Sarnthein et al., 2003).

Mais recentemente, o Projeto MARGO (Multiproxy Approach for the Reconstruction of the Glacial Ocean Surface, Kucera et al., 2005a) voltou a abordar a questão das condições oceânicas superficiais no UMG em escala global, proporcionando as estimativas mais completas até o momento (Fig. 3.3). Os membros do Projeto argumentam que nenhum dos proxies existentes hoje pode ser considerado melhor do que os demais e, portanto, a melhor maneira de obter boas estimativas de paleotemperatura é através da combinação de vários proxies, ou seja, de uma abordagem "multiproxy". Para isto, foram obtidas estimativas de paleotemperatura derivadas do estudo de microfósseis (funções de transferência em dados de abundâncias de foraminíferos planctônicos, diatomáceas, cistos de dinoflagelados e radiolários) e de indicadores geoquímicos (razão $\mathrm{Mg} / \mathrm{Ca}$ em foraminíferos planctônicos e alquenonas). Os diferentes proxies proporcionaram estimativas similares na faixa de latitudes compreendida entre $30^{\circ} \mathrm{S}$ e $30^{\circ} \mathrm{N}$, mas, nas altas latitudes principalmente do Atlântico Norte, há divergências significativas.

Apesar das discrepâncias entre os diferentes proxies, as estimativas do MARGO confirmam os resultados do GLAMAP de um resfriamento tropical maior do que o proposto pelo CLIMAP (MARGO, 2009). Os resultados do Projeto MARGO também indicam um resfriamento pequeno (menos de $2^{\circ} \mathrm{C}$ ) nos centros dos giros subtropicais e um resfriamento intenso nas correntes de contorno leste do hemisfério Sul. Este resfriamento poderia ser o resultado de um aumento da ressurgência ao longo das margens continentais e, no caso do Atlântico Sul, também poderia ser o resultado da intensificação da advecção de águas subpolares para a corrente de Benguela através do 
aumento da intensidade e migração para o norte dos ventos de oeste e a migração dos sistemas frontais do Oceano Austral em resposta ao aumento de gelo ao redor da Antártica (MARGO, 2009).
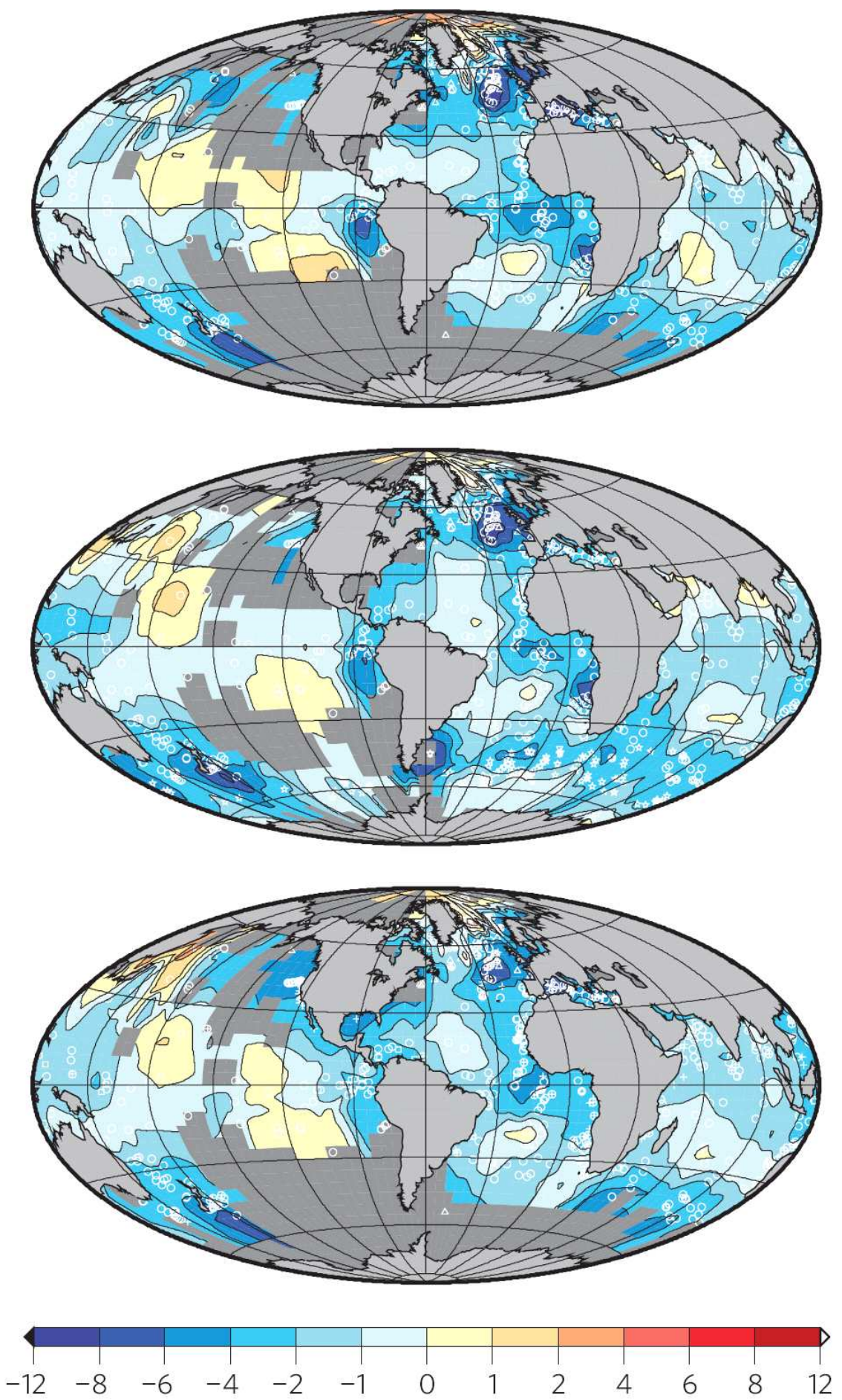

Fig. 3.3. Mapas de anomalias de TSM para o UMG computadas a partir da comparação das estimativas do Projeto MARGO (2009) com os valores modernos de TSM do WOA98. Estimativas para o inverno austral (topo), verão austral (meio) e média anual (figura inferior). Os símbolos brancos indicam a localização dos dados proxies utilizados na reconstrução. 
Mesmo moderado, o resfriamento do Atlântico tropical no UMG teria implicado em uma diminuição significativa da transferência de calor e sal através do equador para o Atlântico Norte (Pflaumann et al., 2003). Além de causar uma diminuição da evaporação, o resfriamento das águas superficiais nos trópicos teria reduzido a intensidade dos ventos alísios e a ciclogênese, os quais cumprem um papel fundamental no transporte de vapor d'água para o oeste, do Atlântico Norte Tropical para o Pacifico oriental (Benway e Mix, 2004). Isto teria afetado a concentração de sal na região e a exportação deste sal para o norte através da corrente do Golfo o que teria limitado a formação de águas profundas (Rahmstorf, 1995).

Um resultado fundamental do MARGO são as evidências robustas de fortes gradientes de temperatura no sentido leste-oeste, principalmente no oceano Atlântico, o que contrasta com os resultados dos modelos climáticos mais recentes como o PMIP2 (Paleoclimate Modeling Intercomparison Project (Fase 2), Braconnot et al., 2007). A discrepância entre os resultados de modelagem e os dados do MARGO evidencia falhas nos modelos, provavelmente devido à falta de inclusão de algumas forçantes como a distribuição de poeira e aerossóis nas simulações do clima no UMG (MARGO, 2009).

Além das estimativas da amplitude de variação da TSM nos trópicos, o CLIMAP também foi questionado em relação às estimativas de TSM extremamente baixas e a idéia de uma cobertura permanente de gelo marinho nas altas latitudes, particularmente no Atlântico Norte, nos mares da Groenlândia, Islândia e Noruega. De acordo com estudos mais recentes (por ex. de Vernal e Hillaire-Marcel, 2000, Pflaumann et al., 2003; Weinelt et al., 2003), no entanto, os mares nórdicos teriam ficado livres de significativa cobertura de gelo durante o verão. Da mesma forma, os estudos mais recentes em relação à extensão do gelo marinho no Oceano Austral (Gersonde et al., 2003, 2005) sugerem que as estimativas do CLIMAP estavam corretas para o inverno com uma expansão do gelo marinho de em torno de $100 \%$ em relação ao volume atual, mas superestimavam significativamente a extensão do gelo no verão. Como resultado da expansão da cobertura de gelo no Ártico e no Oceano Austral, os gradientes de temperatura dos pólos ao equador foram intensificados, assim como os gradientes de pressão atmosférica e, portanto, a intensidade do sistema de ventos. 


\subsection{A DEGLACIAÇÃO}

A transição do glacial para o atual interglacial ocorreu em etapas e se caracterizou por mudanças climáticas abruptas. Diferentemente dos ciclos glaciais e interglaciais que ocorreram de forma aproximadamente simultânea em todo o planeta, as mudanças abruptas que marcaram a última deglaciação não ocorreram globalmente em sincronia (Broecker, 2000). Ainda hoje, não se sabe com precisão o alcance geográfico dos diferentes eventos que marcaram o período de transição e o seu tempo exato. Isto se deve, principalmente, à dificuldade de definir com exatidão as escalas de tempo dos diferentes registros (Dunbar, 2003). Sem esta precisão, não é possível definir o tempo exato em que ocorreram as mudanças climáticas e, conseqüentemente, identificar possíveis feedbacks e estabelecer relações de causa e efeito.

A seqüência de eventos está mais bem documentada no Atlântico norte, onde as mudanças foram mais bruscas. Ali, os principais eventos foram o evento frio Heinrich 1 (H1, 16,8 anos AP), o período de aquecimento Bolling-Allerod (B/A, de 14,5 a 13 mil anos AP), e o breve retorno às condições glaciais conhecido como Younger Dryas (YD, de 13 a 11,5 mil anos AP). No hemisfério sul, as mudanças entre períodos quentes e frios ocorreram de forma oposta ao hemisfério norte e, de maneira geral, foram mais graduais (Barker et al., 2009). O aquecimento iniciou na Antártida entre 17 e 20 mil anos atrás acompanhando a elevação dos níveis atmosféricos de $\mathrm{CO}_{2}$ e a elevação do nível do mar global (Rahmstorf, 2002). O aquecimento foi seguido de um retorno às condições frias na Antártida conhecido como a Reversão Fria Antártica (Antarctic Cold Reversal, ACR) e, finalmente, o aquecimento foi retomado enquanto ocorria o YD no hemisfério norte. Cada um destes períodos se caracterizou por uma organização diferente do sistema climático e da circulação oceânica.

A defasagem entre hemisférios em escala de tempo milenar tem sido amplamente documentada (por ex. Charles et al., 1996; Little et al., 1997; Blunier et al., 1998; Vidal et al., 1999). Contudo, os mecanismos de interação entre hemisférios permanecem incertos. A conexão entre hemisférios pode ocorrer via atmosfera ou oceano, mas o tempo de defasagem entre as mudanças climáticas na Groenlândia e na Antártida sugerem que a conexão seja oceânica (Blunier et al., 1998, Vidal et al., 1999), provavelmente associada em parte, mas não totalmente (Bard et al., 1997) à alternação bipolar na formação de águas profundas (Broecker, 1997a). 
A deglaciação iniciou com o primeiro pulso de degelo ocorrido há 19 mil anos (Clark et al., 2004). Desde então até 7 mil anos atrás, houve uma significativa diminuição do volume de gelo global e uma conseqüente elevação do nível eustático (Lambeck et al., 2002). O processo de degelo e as taxas de elevação do nível do mar não foram contínuos (Fig. 3.4). Em alguns períodos houve uma estabilização do nível do mar e, em outros, ocorreram intensos pulsos de degelo. Estas oscilações ficam evidentes nas reconstruções de variações do nível do mar. Estas reconstruções, no entanto, não permitem definir a origem das águas de degelo.

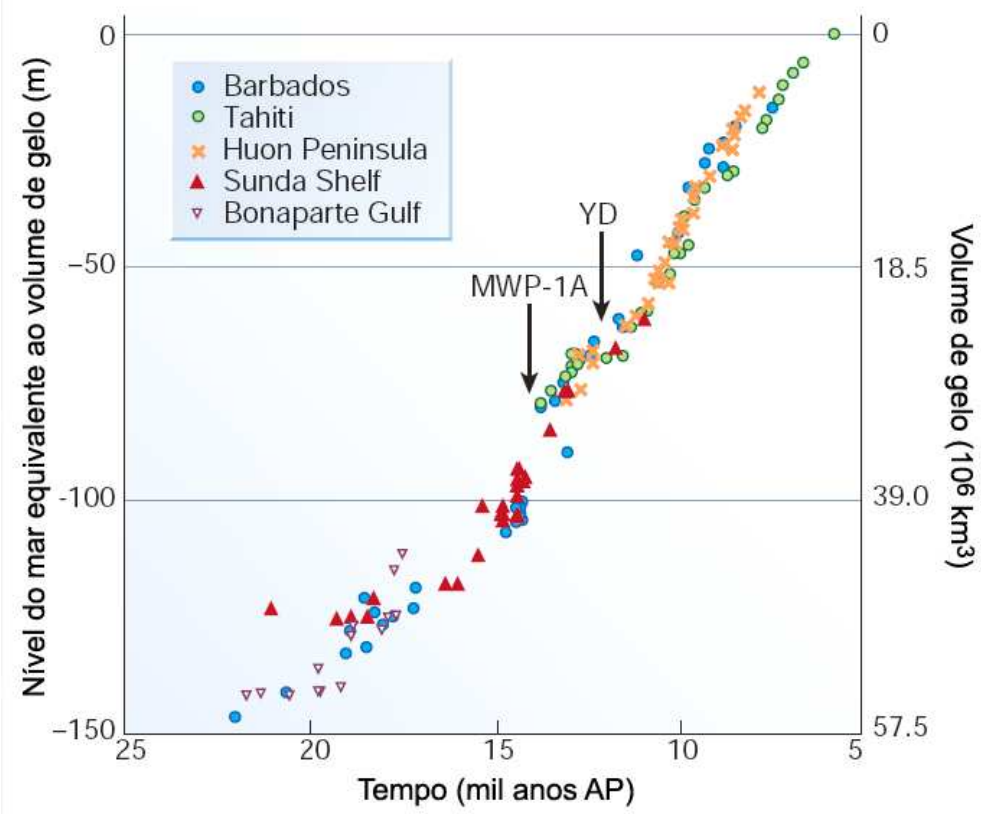

Fig. 3.4. Estimativas de variações no volume de gelo global e correspondentes variações do nível do mar para os últimos 20 mil anos de acordo com Lambeck et al. (2002). As setas indicam o rápido pulso de degelo MWP-1a e a estabilização durante o YD.

\subsubsection{Início da deglaciação: aquecimento no Sul e armadas de icebergs no Atlântico Norte}

O evento mais significativo do início da deglaciação foi o H1 entre 17,5 a 16 mil anos. Assim como nos demais eventos Heinrich, ocorreu um desprendimento de uma grande quantidade de icebergs a partir das geleiras. No seu curso, o derretimento dos icebergs foi liberando sedimentos tipicamente glaciais que ficaram preservados nos sedimentos. As camadas de clastos depositados a partir do derretimento de gelo são 
conhecidas como Ice Rafted Debris (IRD). As causas dos eventos Heinrich ainda não foram bem esclarecidas, podendo estar relacionadas à própria dinâmica das geleiras pela sua desestabilização após um período de crescimento (por ex. MacAyeal, 1993), ou a fatores externos como, por exemplo, a desestabilização das plataformas de gelo desencadeada por uma elevação do nível do mar (por ex. Fluckiger et al., 2006).

Independentemente das causas, o derretimento do gelo implicou na entrada de um gigantesco volume de água doce no Atlântico Norte. O resultado foi a interrupção da formação da APAN (Sarnthein et al., 1994) e a quase interrupção da MOC (McManus et al., 2004; Gherardi et al., 2005, 2009) (Fig.3.5). A redução drástica na exportação de calor e sal para o norte relacionado ao enfraquecimento da MOC teria resultado em um acúmulo de calor e sal no Atlântico tropical (Rühlemann et al., 1999).

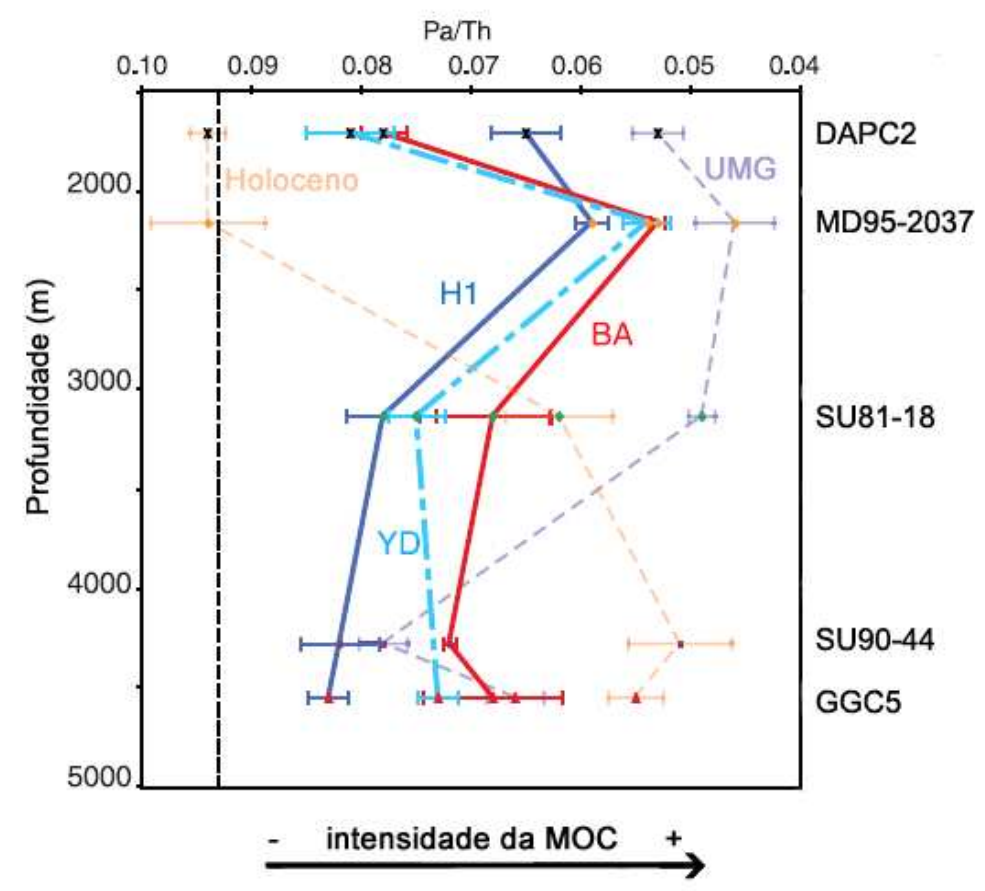

Fig. 3.5. Razão ${ }^{231} \mathrm{~Pa} /{ }^{230} \mathrm{Th}$ em amostras de sedimentos de períodos correspondentes ao $\mathrm{H} 1$ (linha azul), BA (linha vermelha) e YD (azul claro pontilhado) de diferentes profundidades do Atlântico Norte (Gherardi et al., 2009). As estimativas para o UMG e Holoceno da Fig. 3.2. foram desenhadas em linhas claras pontilhadas párea comparação. A escala da razão ${ }^{231} \mathrm{~Pa} /{ }^{230} \mathrm{Th}$ está invertida de maneira a mostrar uma MOC mais intensa do lado direito da figura. A linha vertical pontilhada indica a taxa de produção. Os testemunhos são os mesmos da Fig. 3.2. 
Existem evidências de que os eventos Heinrich tiveram um alcance global ou, ao menos, em todo o hemisfério norte. A maioria dos estudos fora da área de influência direta do degelo mostra eventos correlacionados causados por mudanças no sistema de ventos (Hemming, 2004).

\subsubsection{Resfriamento no Sul e aquecimento no Norte}

O ACR marca uma pausa na tendência ao aquecimento durante a deglaciação na Antártida iniciando entre 14 e 15 mil anos AP e culminando entre 1 e 1,5 mil anos depois (Morgan et al., 2001) (a incerteza na definição temporal do evento se deve às diferenças entre os registros de testemunhos de gelo da Antártica). Ao mesmo tempo, no hemisfério norte ocorria o período de aquecimento BA.

Até pouco tempo atrás se acreditava que, durante o período BA, a CTH tinha sido semelhante à circulação atual. No entanto, de acordo com os estudos mais recentes baseados na razão ${ }^{231} \mathrm{~Pa} /{ }^{230} \mathrm{Th}$ (Gherardi et al., 2009), a circulação durante o BA teria sido muito diferente da atual, com características intermediárias entre as do UMG (com uma célula meridional do Atlântico mais ativa) e o evento H1 (com uma circulação meridional muito enfraquecida) e com um fluxo moderado em todas as profundidades (Fig.3.5).

Aproximadamente neste período ocorreu o maior pulso de degelo da última deglaciação, conhecido como pulso de degelo 1a (Meltwater Pulse la ou MWP1a) o qual foi responsável por uma elevação do nível do mar de em torno de $20 \mathrm{~m}$ em apenas 500 anos (Clark et al., 2002a). Apesar da importância deste primeiro pulso de degelo 1a, ainda não se sabe ao certo a origem da água. De acordo com McManus et al. (2004), apesar do volume de água doce que entrou no oceano no MWP1a ter sido muito maior do que o volume liberado no evento H1, durante o evento MWP1a não houve um enfraquecimento do fluxo da célula meridional como no $\mathrm{H} 1$ o que poderia ser explicado por uma origem antártica das águas de degelo. Clark et al. (2002a) também defendem a hipótese de uma contribuição significativa de gelo antártico enquanto Peltier e Fairbanks (2006) sugerem que a contribuição significativa de gelo antártico na elevação do nível eustático teria ocorrido somente no pulso de degelo seguinte (pulso 1b) ocorrido após o YD.

Assim como sobre a origem, também não há consenso quanto à idade exata do MWP1a, com valores publicados variando entre 14 e 14.6 mil anos (Stanford et al., 
2006). A definição da idade do MWP1a é fundamental para compreender a sua relação com os demais eventos climáticos da deglaciação. Para alguns autores, o MWP1a teria sido o gatilho para o B/A (Weaver et al., 2003) enquanto para outros (Stanford et al., 2006), teria sido a causa da interrupção do período de aquecimento Bolling conhecido como Older Dryas.

\subsubsection{Breve retorno às condições glaciais - o Younger Dryas}

Apesar da insolação boreal estar próximo do máximo (Molfino e McIntyre, 1990), enquanto o aquecimento era retomado na Antártida, o hemisfério Norte retornava às condições glaciais no YD. Durante este período, a circulação termohalina do Atlântico Norte foi desacelerada (Rahmstorf, 2002) e a MOC teria apresentado características intermediárias entre aquelas do $\mathrm{H} 1$ e do B/A (Gherardi et al., 2009) (Fig.3.5). As reconstruções do nível do mar mostram que durante o YD o nível eustático se manteve estável (Lambeck et al., 2002).

Dentre as mudanças climáticas abruptas recentes, o YD é provavelmente a mais bem documentada (Stocker e Marchal, 2000). Apesar disso, ainda existem controvérsias quanto à extensão geográfica do evento (Singer et al., 1998). A maior parte das evidências sugere que o evento ficou restrito ao hemisfério norte, mas alguns autores (ex. Hajdas et al., 2003) identificaram eventos frios no hemisfério sul como sendo simultâneos ao YD. A existência ou não de um resfriamento da mesma idade que o YD no hemisfério sul tem sido motivo de debate por mais de uma década e ainda não há consenso ao respeito.

Mesmo que não tenha sido um evento de resfriamento global como a maior parte dos estudos sugere, outros eventos fora das altas latitudes do hemisfério norte parecem estar relacionados ao YD. Por exemplo, há evidências de que, no Atlântico equatorial, a termoclina e nutriclina ficaram mais rasas provavelmente devido à intensificação dos ventos alísios (Molfino e McIntyre, 1990; Kim e Schneider, 2003). Provavelmente, o responsável pela rápida propagação do impacto do YD em todo o hemisfério Norte e os trópicos foi a intensa formação de cobertura de gelo marinho durante o inverno o que geraria condições ultra frias no norte e deslocaria a banda chuvosa tropical na direção sul e enfraqueceria os monções (Broecker, 2006). De acordo com Broecker, (2006), um mecanismo similar teria acontecido durante os eventos Heinrich. Da mesma maneira, o enfraquecimento da MOC durante o YD teria sido o responsável mais uma vez pela 
redução de exportação de calor para o hemisfério norte e o seu consequiente acúmulo no Atlântico tropical (Rühlemann et al., 1999; Dahl et al., 2005).

A origem do YD é amplamente debatida. As hipóteses mais comuns recorrem a variações na $\mathrm{CTH}$ associadas à introdução de água de degelo no oceano. Hipóteses alternativas sugerem que possa ter agido uma forçante global como a variabilidade solar (Renssen et al., 2001) ou até o impacto de cometas (Firestone et al., 2007; Kennett et al., 2009). Por enquanto, no entanto, não existem evidências conclusivas sobre nenhuma destas hipóteses. O que se sabe, porém, é que assim como nos eventos Heinrich, durante

o YD ocorreram intensas reorganizações da CTH e, se bem estas poderiam ser conseqüência de mudanças climáticas iniciadas em outros lugares, existem bons indícios de que na realidade, tais mudanças na CTH poderiam constituir o principal gatilho das demais mudanças climáticas (Broecker, 2003).

\subsection{O HOLOCENO}

Até pouco tempo atrás se acreditava que o Holoceno teria sido um período relativamente calmo e com pouca variabilidade climática. Se bem comparado à última deglaciação o Holoceno pode ser considerado um período mais homogêneo, um olhar em maior detalhe revela que este período esteve longe de ser calmo e que o clima, a geomorfologia e os ecossistemas do início do Holoceno não eram os mesmos de hoje em dia nem permaneceram os mesmos durante todo este tempo (Roberts, 1998). A configuração geral das áreas emersas ainda era diferente da atual devido ao nível do mar reduzido. Desde o início do Holoceno até em torno de 6 mil anos AP o nível do mar subiu de $-55 \mathrm{~m}$ até níveis semelhantes aos atuais, acompanhando o recuo das grandes geleiras (Roberts, 1998).

De maneira geral o Holoceno pode ser subdividido em três etapas (Wanner et al., 2008): (1) de 11,6 a 9 mil anos AP, quando o Hemisfério Norte estava sujeito a um máximo de insolação de verão, mas ainda sofria os efeitos de grandes geleiras; (2) de 9 a 6 ou 5 mil anos AP, quando a insolação de verão no Hemisfério Norte era alta e a influência das geleiras era pequena e (3) de 6 ou 5 mil anos AP até o fim do tempo préindustrial quando ocorreu um declínio da insolação de verão no Hemisfério Norte. As principais mudanças climáticas ocorridas neste terceiro período foram analisadas em detalhe e sintetizadas em um mapa por Wanner et al. (2008) (Fig. 3.6). 


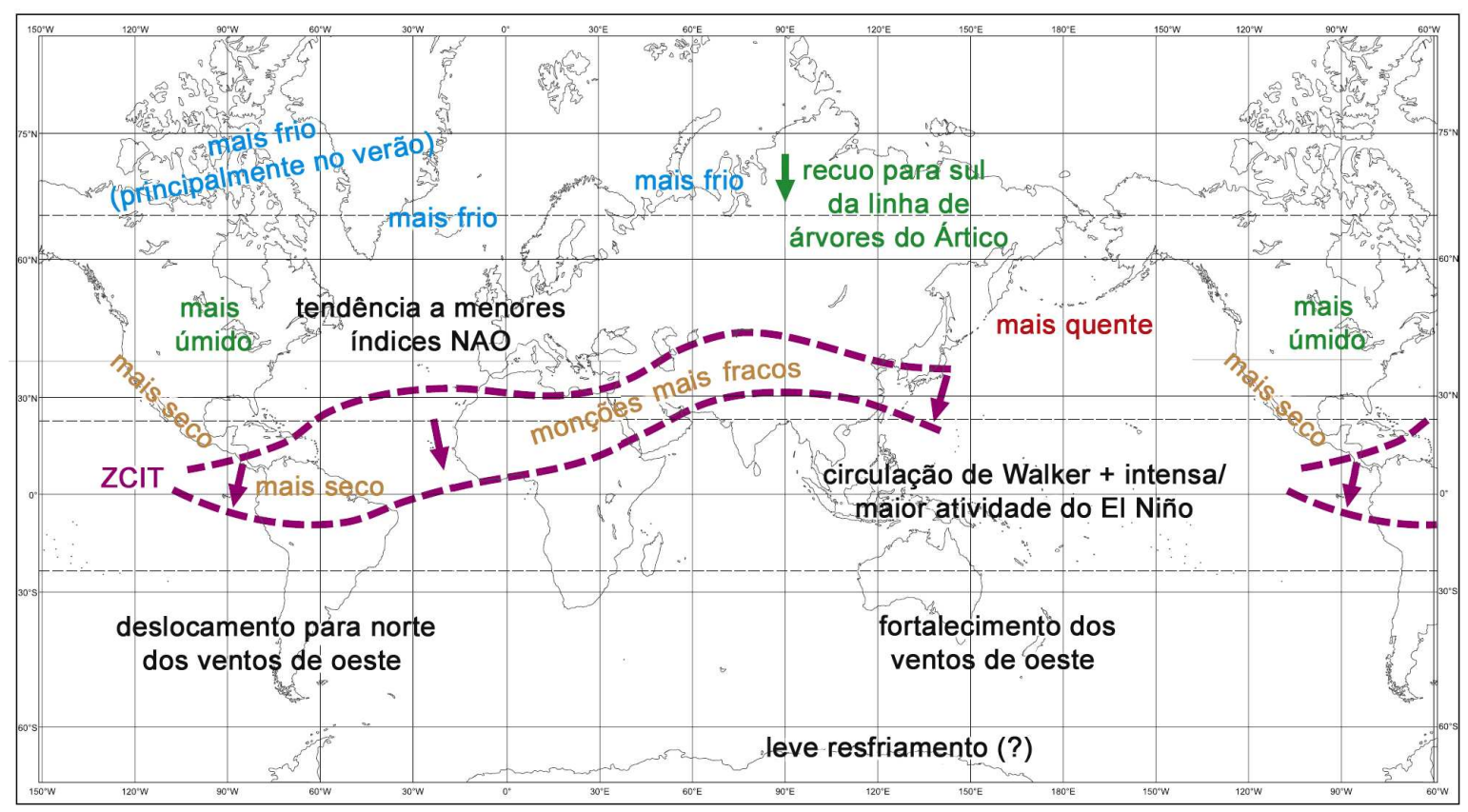

Fig. 3.6. Síntese espacial das mudanças climáticas globais ocorridas no período pré-industrial, quando comparado ao Holoceno Médio (6 mil anos AP), de acordo com Wanner et al. (2008).

A atual configuração da distribuição de massas d'água profundas iniciou aproximadamente há 9 mil anos (Came et al., 2003). Um dos possíveis fatores responsáveis pela retomada da produção da APAN foi o fortalecimento da MOC é o restabelecimento de uma forte conexão entre os oceanos Índico e Atlântico através dos anéis da corrente das Agulhas (Peeters et al., 2004). Através de um modelo de circulação oceânica tridimensional, Knorr e Lohmann (2003) mostram que o aumento do transporte de massa para o oceano Atlântico através das rotas quente (Oceano Índico) e fria (Oceano Pacífico) teria induzido uma rápida reativação do modo interglacial da CTH contrabalançando o efeito da entrada de águas de degelo, a qual levaria a um enfraquecimento da CTH.

Analisando diferentes registros continentais e oceânicos disponíveis, Denton e Broecker (2008) sugerem que a produção de águas profundas no Atlântico Norte vem se enfraquecendo pelo menos desde o Holoceno Médio em relação às águas profundas do Oceano Austral e que, sobreposto a este declínio, teriam existido oscilações na escala milenar e secular. Oppo et al. (2003) também apresentam evidências de flutuações significativas na produção de APAN durante o Holoceno. 
De acordo com Bond et al. (1997) as variações milenares ocorridas no Atlântico Norte durante o Holoceno teriam sido cíclicas, com uma frequiência próxima a 1500 anos; estatisticamente, a mesma freqüência dos eventos que marcaram a última glaciação. Isto significaria que os ciclos de Dansgaard/Oeschger característicos do glacial e especialmente bem desenvolvidos no estágio marinho isotópico 3 e os eventos Heinrich associados às fases frias dos ciclos não teriam sido forçados por instabilidades internas dos grandes mantos de gelo durante as glaciações, mas sim por processos ligados ao clima.

As evidências de variabilidade em escala milenar não se restringem ao Atlântico Norte. Mayewski et al. (2004) apresentaram uma compilação de registros paleoclimáticos que mostram ao menos seis mudanças rápidas, a maioria delas caracterizada por resfriamento nos pólos, aridez nos trópicos e mudanças significativas na circulação atmosférica. Os autores não comparam a magnitude e o ritmo destas mudanças com as ocorridas durante o último glacial, mas mostram que elas foram o suficientemente rápidas do ponto de vista da civilização humana. Douglass et al. (2005) também detectaram um sincronismo entre oscilações climáticas observadas no sul da América do Sul e na Groenlândia sugerindo que, se existir uma relação causal entre ambos eventos, então estas mudanças abruptas seriam forçadas externamente (por ex. por variabilidade solar) ou se propagariam rapidamente ao redor da Terra (por ex. processos atmosféricos).

Sobreposto às variações em escala milenar, outra importante causa de variabilidade do clima no Holoceno se deve aos eventos El Niño. Vários estudos (por ex. Tudhope et al., 2001, Moy et al., 2002; Cane, 2005) indicam que os eventos ENOS eram mais fracos ou mesmo ausentes no início do Holoceno e que do Holoceno médio em diante a freqüência deste eventos teria aumentado até um máximo em torno de 1,2 mil anos AP (Fig.3.6).

\subsubsection{Forçantes de variabilidade climática no Holoceno}

Os principais fatores determinantes da variabilidade climática do Holoceno incluem a forçante orbital, a variabilidade solar e a atividade vulcânica. Outros fatores como mudanças na concentração de gases de efeito estufa e mudanças na cobertura do solo, além de agirem como importantes forçantes constituem também reatores e estão envolvidos em complexos mecanismos de retroalimentação (Wanner et al., 2008). 
Além disto, devem ter existido oscilações internas próprias do sistema oceanoatmosfera (Crowley e North, 1991).

A principal mudança induzida pelos parâmetros orbitais durante o Holoceno foi a sazonalidade. Em função do ciclo de precessão dos equinócios, atualmente o hemisfério sul encontra-se mais afastado do Sol no inverno austral (junho) e mais próximo no verão (dezembro) o que causa um intenso contraste sazonal. Já 11 mil anos atrás, a Terra estava mais próxima do Sol em junho e mais afastada em dezembro, portanto reduzindo o contraste sazonal no hemisfério sul (Berger e Loutre, 1991) (Fig. 3.7). Como resultado, a ZCIT estava localizada mais ao norte, provavelmente intensificando a penetração de advecções polares (Martin et al., 1997). Subseqüentemente, ao longo do Holoceno, mudanças na insolação associadas ao ciclo de precessão teriam causado uma migração geral da ZCIT para o sul (Haug et al., 2001).

Tudhope et al. (2001) sugerem um controle precessional sobre a intensidade dos eventos ENOS combinado a uma segunda componente glacial com efeito de amortecimento. Os efeitos do ciclo de precessão sobre a intensidade das monções é mais conhecida ainda e foi bem demonstrada por modelos climáticos (por ex. Kutzbach e Otto-Bliesner, 1982; Prell e Kutzbach, 1987; Liu et al., 2003). O exemplo mais claro é o Período Úmido Africano (African Humid Period, Roberts, 1998; aproximadamente de 9 a 6 mil anos AP). Este período foi causado pelo aumento da insolação de verão no hemisfério norte que aumentou significativamente a pluviosidade, permitindo o desenvolvimento de pradarias, lagos e áreas alagadiças na região atualmente ocupada pelo deserto de Saara (COHMAP, 1988). A resposta dos sistemas de monção às mudanças de insolação, no entanto, não é linear e varia significativamente de uma região a outra devido a feedbacks que amplificam ou amortecem a forçante inicial (por ex . Kutzbach e Guetter, 1986; Kutzbach et al., 1996; Kutzbach e Liu, 1997; Claussen et al., 1999; deMenocal et al., 2000; Carrington et al., 2001; Liu et al., 2004).

De acordo com Mayewski et al. (2004) de todos os possíveis mecanismos forçantes, a variabilidade solar sobreposta às mudanças de longo prazo na insolação, é a candidata mais plausível para as mudanças climáticas rápidas do Holoceno. O Sol é, sem dúvida, a principal forçante do sistema climático, mas ainda sabe-se pouco sobre a maneira como a variabilidade solar pode afetar o clima. A resposta do sistema climático a variações na radiação solar não depende apenas da quantidade de energia recebida e da distribuição sazonal desta energia na Terra (determinadas pelos parâmetros orbitais), mas também da composição espectral da radiação e de complexos mecanismos de 
feedback, o que dificulta extremamente o estabelecimento de relações quantitativas entre as variações climáticas observadas e a variabilidade solar (Beer et al., 2000). No entanto, existem evidências de variações que sugerem uma modulação solar sobre o clima (Bond et al., 2001; Renssen et al., 2001; Rohling et al., 2002).
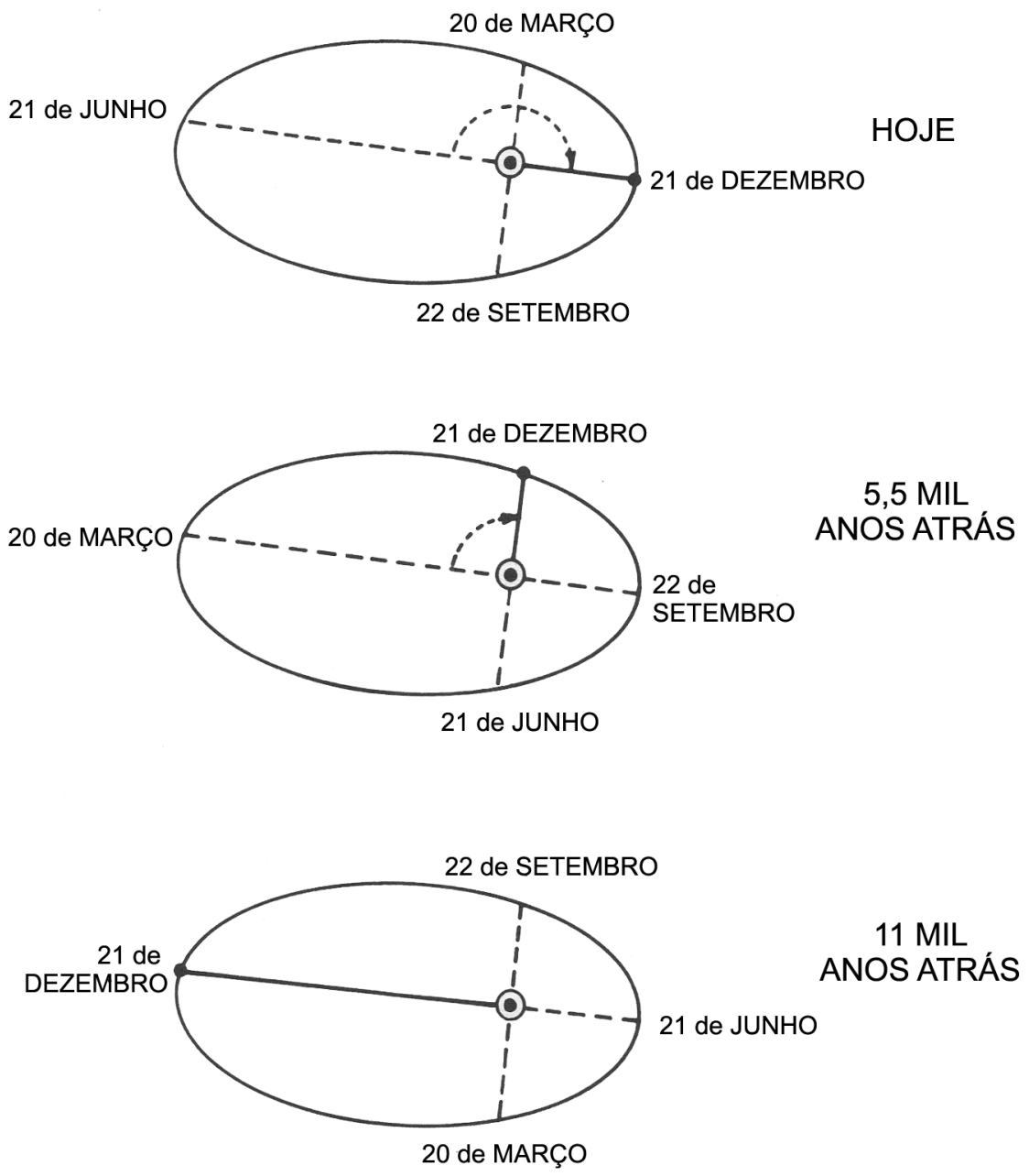

- TERRA no dia 21 de DEZEMBRO

(-) SOL

Fig. 3.7. A posição dos equinócios e solstícios muda lentamente ao redor da órbita elíptica da Terra, levando um tempo aproximado de 22 mil anos para completar um ciclo. Enquanto hoje a Terra se encontra mais próxima do sol durante o solstício de verão austral, há 11 mil anos a situação era a oposta (Imbrie e Imbrie, 1979). 
O efeito das erupções vulcânicas sobre o clima se deve à liberação de grandes quantidades de aerossóis na atmosfera os quais aumentam o albedo causando um resfriamento. No entanto, os efeitos de uma erupção vulcânica podem durar apenas um par de anos até os efeitos da gravidade e da precipitação "limparem" a atmosfera e, para ter uma grande repercussão, seriam necessárias muitas erupções de grandes dimensões. Por outro lado, para afetar ambos os hemisférios e ter repercussão global, as erupções precisariam ser a partir dos trópicos (Ruddiman, 2005). Isto significa que, apesar dos efeitos das erupções vulcânicas sobre o clima em curtas escalas de tempo serem incontestáveis, dificilmente elas poderiam explicar variações de maior escala.

Outro fator importante na determinação do clima são os gases de efeito estufa. De acordo com dados de testemunhos de gelo, no início do Holoceno ocorreu uma diminuição da concentração de $\mathrm{CO}_{2}$ atmosférico de em torno de 7 ppm até aproximadamente 8 mil anos AP, quando começou um novo aumento de em torno de 20ppm até os níveis pré-industriais de 280ppm (Indermühle et al., 1999; Monnin et al., 2001). As causas responsáveis por tais mudanças são motivo de debate, principalmente desde o surgimento da hipótese de Ruddiman (2003), segundo a qual a influência do homem sobre o clima teria começado muito antes da era industrial, já em torno de 8 mil anos atrás com o desenvolvimento da agricultura. De acordo com Ruddiman, as atividades humanas teriam sido as responsáveis pelas mudanças na concentração de $\mathrm{CO}_{2}$ e $\mathrm{CH}_{4}$ na atmosfera. De fato, o Holoceno foi um período de modificações antrópicas crescentes tanto localmente (por ex. no uso do solo) como globalmente (por ex. composição atmosférica) (Jansen et al, 2007). No entanto, de acordo com Joos et al. (2004), as mudanças na concentração de $\mathrm{CO}_{2}$ atmosférico seriam principalmente o resultado de um balanço entre o crescimento de florestas nas áreas antes ocupadas pelo manto de gelo Laurenciano e a compensação do carbonato nos sedimentos oceânicos.

\subsubsection{Principais mudanças climáticas do Holoceno}

As mudanças climáticas mais significativas do Holoceno foram o evento ocorrido há 8,2 mil anos e o período frio mais recente conhecido como a Pequena Idade do Gelo.

O padrão geográfico do primeiro é semelhante ao do $\mathrm{YD}$, mas de menor amplitude (Alley et al, 1997). O episódio foi descrito em diversos locais do hemisfério norte (Baldini et al., 2002). De acordo com Renssen et al. (2002) este evento estaria 
associado a um pulso de degelo a partir do manto de gelo Laurenciano. A comparação de experimentos de modelagem e dados proxies reforça a hipótese deste evento ter sido causado pela liberação abrupta de um grande volume de água doce no Atlântico Norte (LeGrande e Schmidt, 2008).

Já no caso da Pequena Idade do Gelo (aproximadamente de 400 a 150 anos AP), a coincidência de um máximo na atividade vulcânica, uma baixa insolação no hemisfério norte (induzida orbitalmente) e uma concentração excepcional de mínimos de atividade solar sugere que a origem deste evento esteja relacionada a uma combinação destes fatores (Wanner et al., 2008). Apesar de ter sido um resfriamento muito menor do que o ocorrido no último glacial, a mudanças das condições climáticas médias durante este período foram o suficientemente intensas como para ter consequiências ecológicas e humanas mensuráveis (Roberts, 1998). 


\section{MATERIAIS E MÉTODOS}

$\mathrm{Na}$ presente tese, foi analisado o testemunho a pistão KF02 coletado pela Petrobras no talude inferior da Bacia de Santos nas coordenadas 25 50 '15,25"S e 45¹1'53,72'W, sob uma lâmina d'água de 827 m (Fig.2.1). Foram recuperados $489 \mathrm{~cm}$ de sedimento. A descrição do testemunho foi feita logo após a coleta por especialistas da própria empresa.

De acordo com o objetivo da tese, foram obtidas estimativas das variáveis paleoceanográficas baseadas em análises da fauna e de isótopos estáveis de oxigênio e carbono em foraminíferos planctônicos. Para uma correta interpretação dos resultados foi construído um modelo de idade robusto baseado em nove datações de radiocarbono e nos dados de isótopos de oxigênio.

Como o registro do testemunho KF02 não compreendia todo o período desejado, foram analisados também os dados do testemunho SAN76 $\left(24^{\circ} 26^{\prime} \mathrm{S}, 42^{\circ} 17^{\prime} \mathrm{W}\right.$, $1682 \mathrm{~m}$ de profundidade). O testemunho SAN76 foi anteriormente estudado por Costa (2000), Toledo (2000) e Toledo et al. (2007a, 2007b, 2008). Os dados deste testemunho

foram reanalisados após reajustes no modelo de idade e nos cálculos de paleotemperatura e paleossalinidade de acordo com a mesma metodologia empregada na análise do testemunho KF02.

Nas seções 4.1 a 4.6 são descritos os métodos empregados na análise do novo testemunho e, na seção 4.7, detalha-se a reanálise do testemunho SAN76.

\subsection{AMOSTRAGEM E PROCESSAMENTO INICIAL DAS AMOSTRAS}

O testemunho foi amostrado a intervalos de $2 \mathrm{~cm}$, exceto pelo segmento compreendido entre 185 e $215 \mathrm{~cm}$ o qual não pôde ser disponibilizado pela empresa devido ao encaminhamento para outras análises. A quantidade de amostras utilizadas variou dependendo do tipo de análise. A Fig. 4.1 apresenta a distribuição das amostras por tipo de análise realizada. 

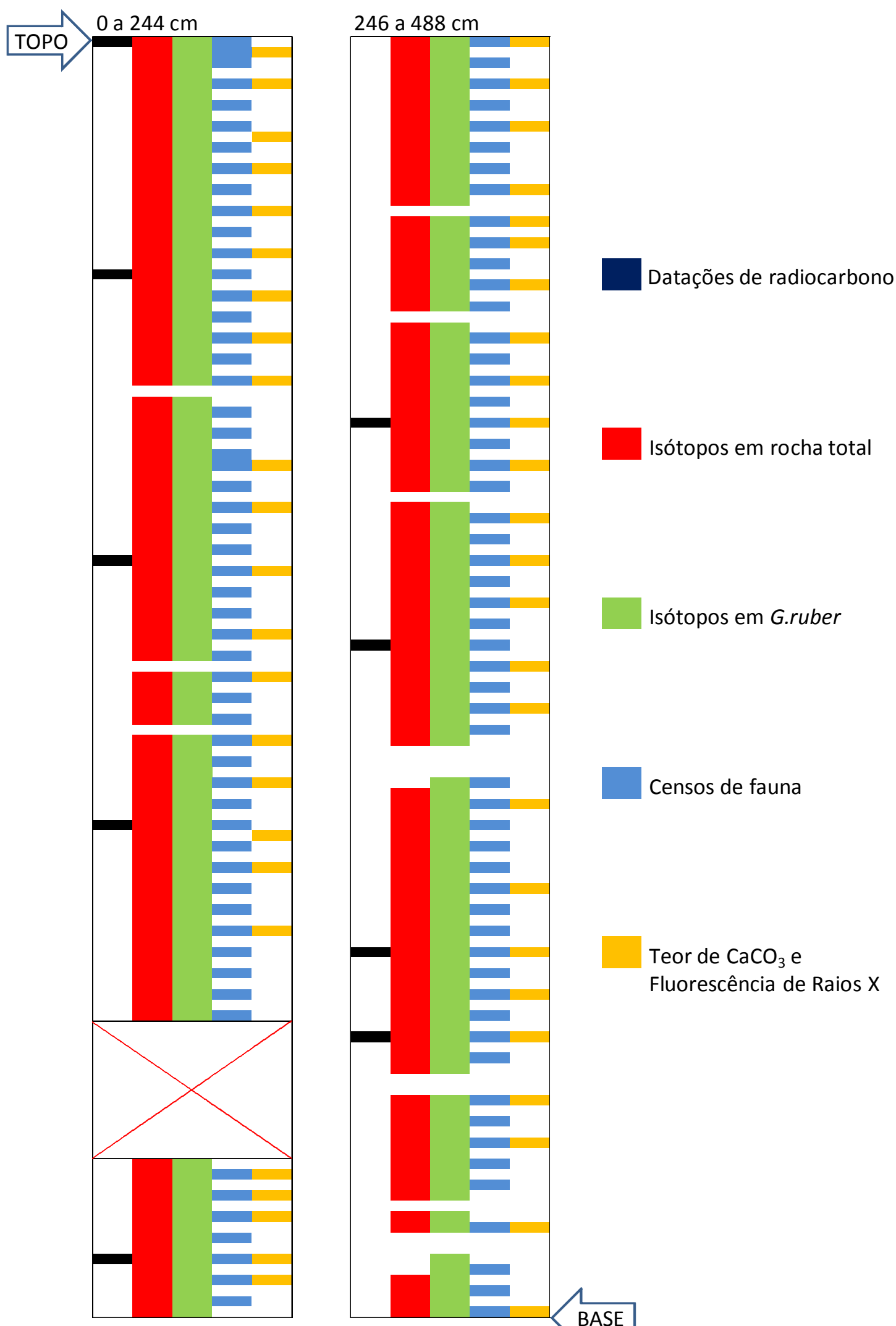

Fluorescência de Raios X

Fig. 4.1. Distribuição das amostras utilizadas por tipo de análise ao longo do testemunho KF02. $\mathrm{O} X$ vermelho indica a seção de testemunho não disponibilizada para análise. 
A preparação das amostras para análises químicas e microfaunísticas iniciou pela lavagem em peneiras de abertura de malha de 0,062 mm para separação das frações fina e grossa, com preservação de ambas frações. Após a lavagem, as amostras foram secas em estufa a temperaturas inferiores a $60^{\circ} \mathrm{C}$ de maneira a preservar as suas propriedades químicas. A fração grossa das amostras foi peneirada mais uma vez para a separação da fração maior que $0,150 \mathrm{~mm}$, com a qual foram realizadas as contagens de fauna e as análises de isótopos de oxigênio em foraminíferos planctônicos. A fração fina foi utilizada em análises de Fluorescência de Raios X (FRX) por Bariani (2009). A Fig. 4.2 apresenta esquematicamente as etapas do processamento das amostras para a obtenção dos resultados propostos.

\subsection{MODELO DE IDADE}

O modelo de idade foi construído a partir da correlação do registro de isótopos de oxigênio em foraminíferos planctônicos com a cronologia de alta resolução do SPECMAP (Spectral Mapping Project) de Martinson et al. (1987) e em nove datações de radiocarbono em amostras monoespecíficas de ao menos 150 espécimes do foraminífero planctônico Globigerinoides ruber (morfotipos white e pink) na fração maior do que $0,15 \mathrm{~mm}$ exceto pela amostra do topo em que também foram analisados espécimes de G.menardii. Os espécimes foram identificados e separados em lupa binocular e lavados em ultrassom. A correlação dos dados foi feita utilizando o programa AnalySeries (Paillard et al., 1996).

A escolha das amostras para datação se baseou nos primeiros dados de isótopos de oxigênio obtidos para este testemunho a partir de amostras de 5 a $10 \mathrm{~g}$ de rocha total e na variação da abundância relativa dos foraminíferos planctônicos do Plexo menardiforme (ver seção 4.3) procurando no possível confirmar eventos "sugeridos" por estas curvas. As amostras escolhidas para datação foram as de 2, 45, 99, 149, 234, $318,360,420$ e $436 \mathrm{~cm}$ de profundidade.

As análises de isótopos em rocha total foram conduzidas pelo Laboratório de Geologia Isotópica da Universidade Federal do Pará (Pará-ISO, UFPR). O laboratório está equipado com um espectrômetro de massas de razão isotópica (IRMS) Finnigan MAT 252, acoplado um periférico KIEL-III para extração online de $\mathrm{CO}_{2}$ em carbonatos. 


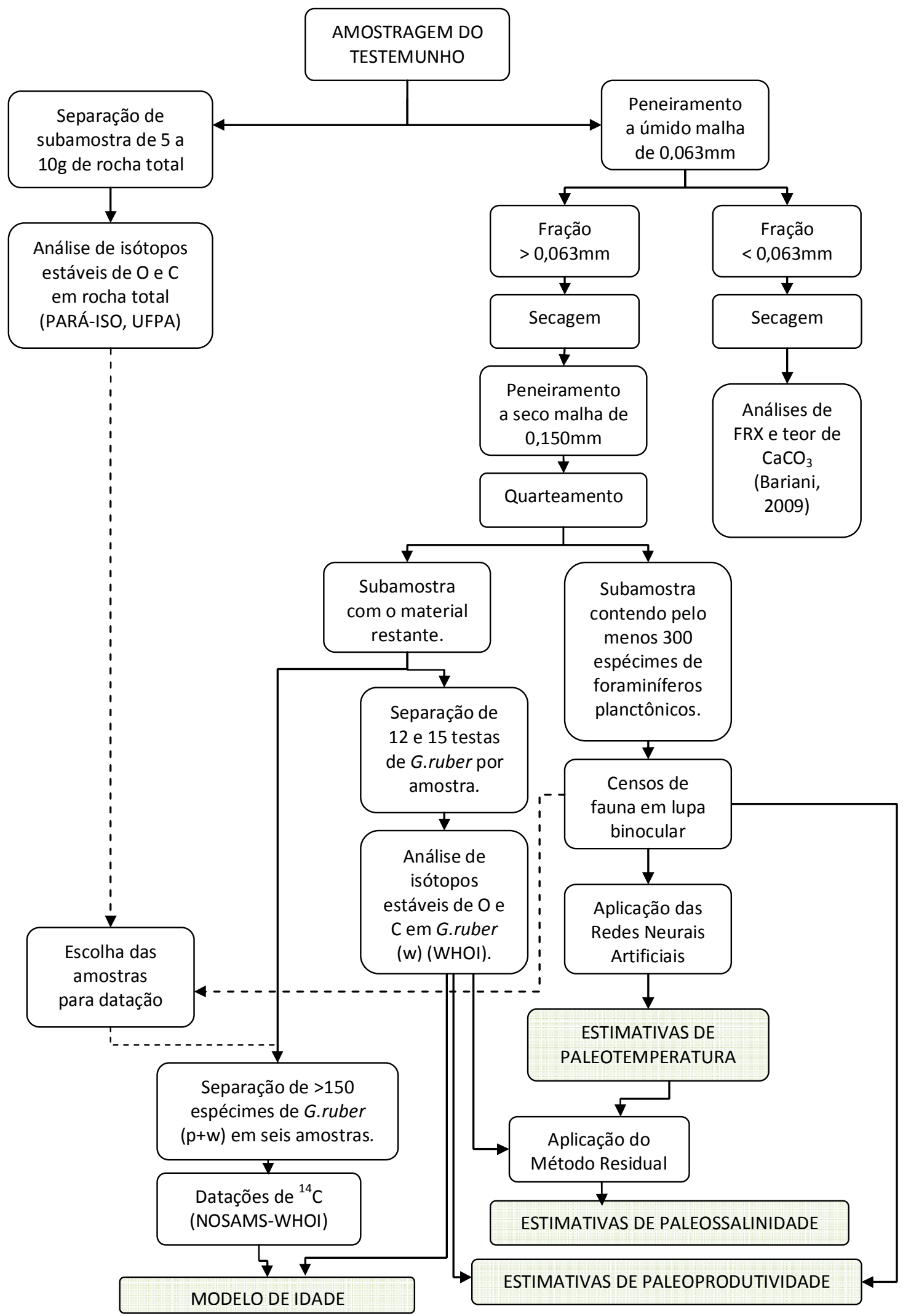

Fig. 4.2. Fluxograma resumido das etapas realizadas para obtenção das estimativas desejadas. 
As análises de ${ }^{14} \mathrm{C}$ foram realizadas pelo Laboratório de Espectrometria de Massa com Aceleradores do Instituto Oceanográfico Woods Hole (NOSAMS-WHOI). As idades foram corrigidas por um efeito de reservatório de 271 anos de acordo com Butzin et al., (2005) e Cao et al., (em prep.) utilizando o programa disponível na página http://radiocarbon.LDEO.columbia.edu/ e transformadas em anos calendário de acordo com a curva de calibração de Fairbanks et al. (2005), versão Fairbanks0107.

Uma vez construído o modelo de idade, foram estimadas as variações na taxa de sedimentação ao longo do testemunho por simples regras de três.

\subsection{ESTIMATIVAS DE PALEOTEMPERATURA}

As estimativas de paleotemperatura se basearam na composição das assembléias de foraminíferos planctônicos presentes nas amostras. Existem diversas abordagens para transformar dados de composição faunal de foraminíferos em estimativas de paleotemperatura. Todas elas se baseiam no pressuposto básico das assembléias de foraminíferos planctônicos terem a sua distribuição principalmente determinada pela temperatura da água na qual eles vivem.

A técnica aplicada nesta tese foi a das Redes Neurais Artificiais (RNAs, Malmgren e Nordlund, 1997), atualmente considerada a mais precisa de acordo com os estudos comparativos de Malmgren et al., (2001) e Kucera e Darling (2002). As análises dos dados da presente tese foram conduzidas pelo Prof. Michal Kucera da Universidade de Tübingen, na Alemanha, já que, por se tratar de uma sofisticada técnica de modelagem numérica que requer um grande esforço computacional, a análise nos computadores do laboratório não era viável. A aplicação do método proporcionou estimativas de paleotemperatura de verão, inverno e paleotemperatura média anual.

Para as contagens de microfauna, as amostras foram quarteadas com microquarteador para a obtenção de subamostras representativas contendo ao menos 300 espécimes de foraminíferos planctônicos, de acordo com a metodologia do CLIMAP (1976, 1981). A contagem e identificação a nível específico dos foraminíferos planctônicos foi feita em lupa binocular seguindo os critérios taxonômicos de Bé (1967, 1977); Bolli e Saunders, (1989); Hemleben et al. (1989) e Kemle von Mücke e Hemleben (1999). Com os dados de abundância foram calculadas as abundâncias relativas para cada espécie em relação ao total de foraminíferos planctônicos 
contabilizados. Embora não tenham relação com as estimativas de paleotemperatura, também foram contabilizadas as quantidades totais de ostracodes e foraminíferos bentônicos e de fragmentos de foraminíferos planctônicos. O critério utilizado para contabilizar os fragmentos foi o de testas incompletas, porém constituindo ao menos $50 \%$ da testa para evitar a contagem múltipla de espécimes.

\subsubsection{As Redes Neurais Artificiais}

As RNAs constituem um ramo da Inteligência Artificial e consistem em um método de solucionar problemas a partir da construção de um sistema formado por circuitos que simulam o cérebro humano. A técnica computacional se baseia em um algoritmo com capacidade de aprendizado autônomo da relação entre dois grupos de números. No nosso caso de interesse, investiga-se a relação entre TSMs e abundâncias relativas de foraminíferos planctônicos. A grande vantagem desta técnica sobre as demais é a sua capacidade de detectar padrões diferentes da dependência linear (Pozzi, 2000). Outras vantagens são uma dependência menor ao tamanho do banco de dados de calibração (quando comparada à Técnica do Análogo Moderno, Hutson (1980)) e a possibilidade de extrapolação, ou seja, de obter estimativas de um parâmetro ambiental fora do espectro contido no banco de dados de calibração (Kucera et al., 2005b).

A arquitetura geral de uma rede neural foi descrita por Malmgren e Nordlund (1997) (Fig.4.3). Esta consiste em uma ou mais camadas contendo um determinado número de unidades de processamento ou neurônios interligados por um grande número de conexões. Estas conexões têm pesos associados de acordo com os quais se modifica por um lado as entradas a partir das variáveis de entrada ou de outros neurônios e, por outro, se envia uma informação de saída que pode ser recebida por outro neurônio ou que pode ser diretamente transformada no parâmetro ambiental desejado.

Em uma primeira etapa do treinamento, os sinais de entrada (no nosso caso, os dados de fauna do conjunto de dados de calibração), são propagados pelas diversas camadas até a camada de saída onde fornecem estimativas de temperatura. A comparação das estimativas geradas com a saída desejada (temperatura conhecida) indica o erro. Na segunda etapa, o erro é retropropagado na rede e os pesos das conexões são reajustados de forma a minimizar o erro.

O treinamento é feito por etapas. Para cada uma delas é utilizado um subconjunto do banco de dados de calibração. Por sua vez, cada subconjunto é dividido 
em dados de treinamento e dados de teste (não pode haver sobreposição entre ambos os tipos). Após cada etapa de treinamento, o subconjunto de teste é usado para calcular o erro de predição. O procedimento se repete até o erro de predição não mais diminuir.

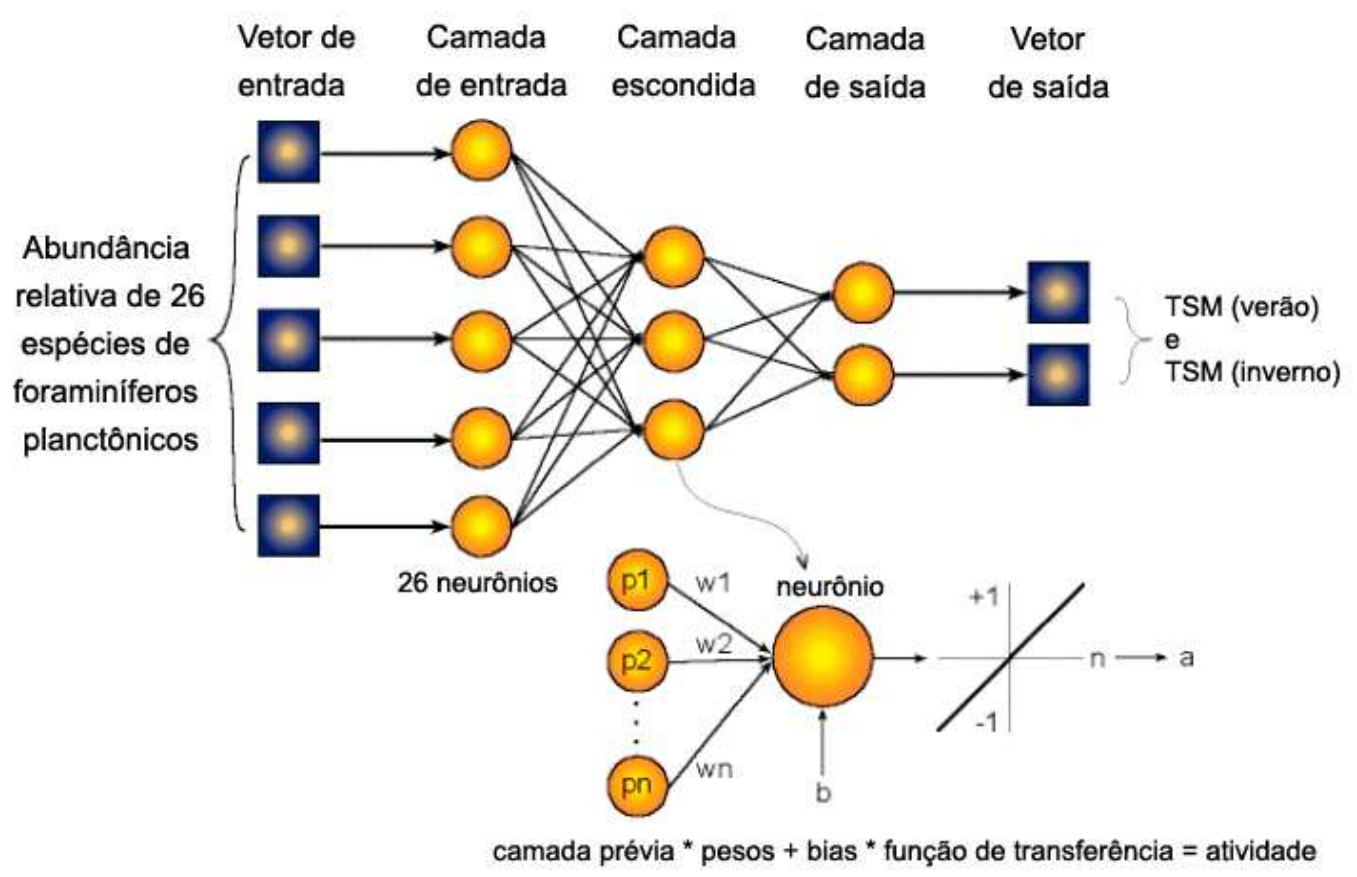

Fig. 4.3. Arquitetura geral de uma rede neural de retropropagação com três camadas. Em cada neurônio das camadas escondidas e da camada de saída são somados os sinais recebidos da camada prévia (p) multiplicados pelos seus respectivos pesos sinápticos (w). A isto é somado um bias (b) ou perturbação com o efeito de aumentar ou diminuir a entrada. O somatório final é filtrado com uma função de transferência (por ex. linear ou sigmoidal) para produzir a atividade (a) do neurônio a qual é enviada à camada subseqüente ou, no caso da última camada, representa diretamente a saída. Adaptado de Malmgren e Nordlund (1997) e Kucera (2003).

As redes utilizadas neste trabalho são as mesmas utilizadas por Kucera et al. (2005b), as quais foram treinadas por bases de dados específicas por bacia oceânica. A limitação geográfica do banco de dados de calibração ajuda a minimizar os problemas associados ao possível agrupamento de espécies crípticas (formas morfologicamente idênticas ou semelhantes, mas genética e ecologicamente diferentes, Kucera e Darling, (2002)), já que tipos genéticos diferentes apresentam um grau de endemicidade maior do que espécies morfologicamente definidas as quais têm uma distribuição mais cosmopolita (Kucera et al., 2005b). No caso do Atlântico Sul, são considerados 26 grupos taxonômicos (Tabela 4.1). Cada conjunto de dados foi dividido em dez pares representativos de subconjuntos de treinamento $(80 \%)$ e teste $(20 \%)$. 
Tabela 4.1. Lista de grupos taxonômicos considerados na obtenção de estimativas de paleotemperaturas aplicando a técnica de RNAs.

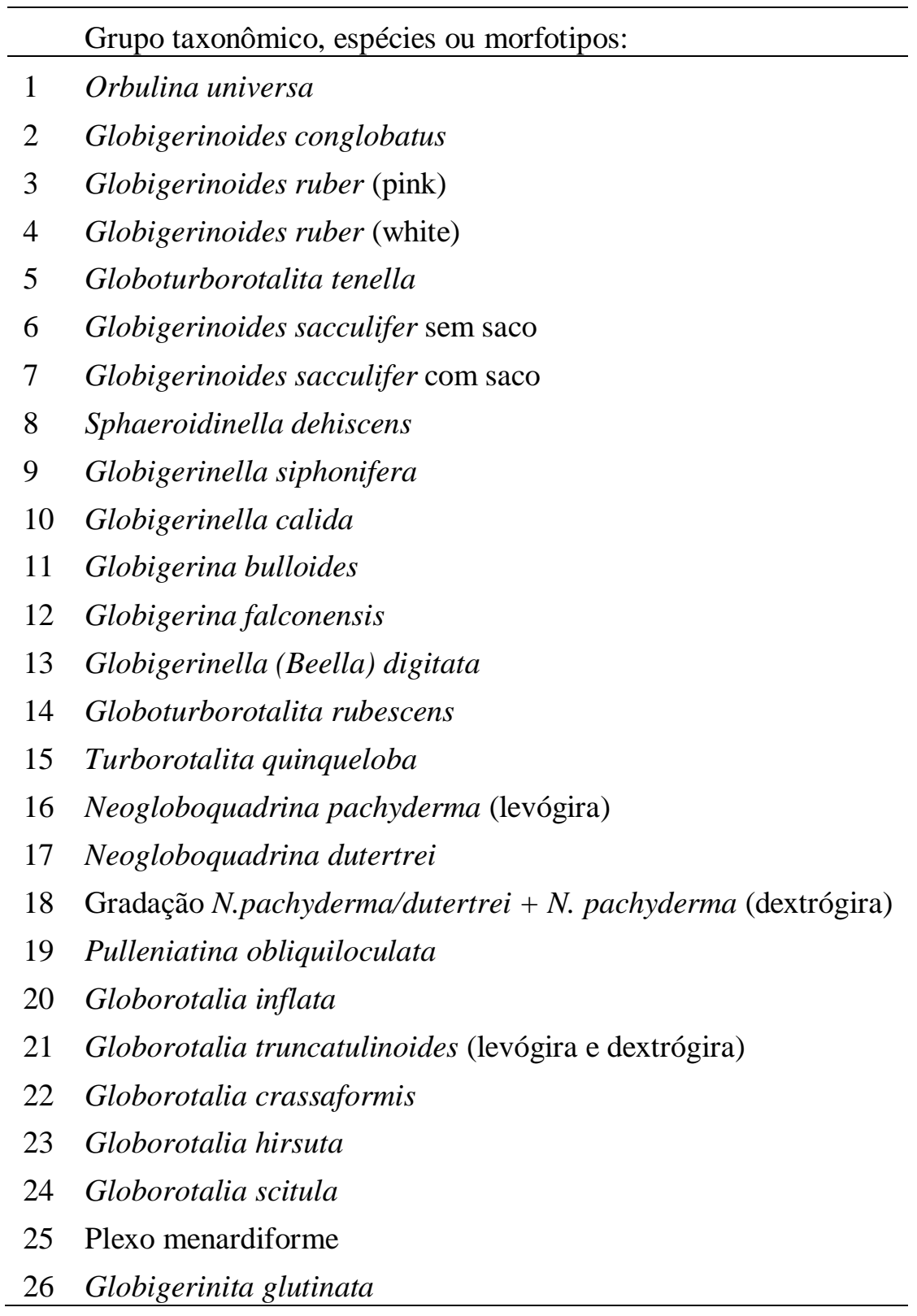

Assim como as demais técnicas que se baseiam na composição da fauna de foraminíferos planctônicos para estimar paleotemperaturas, as RNAs fornecem estimativas de paleotemperaturas de verão mais confiáveis do que as de inverno, apesar de haver uma tendência de subestimar as TSMs mais elevadas (Malmgren et al., 2001). De acordo com Weinelt et al. (2003) as RNAs parecem não se desempenhar tão bem apenas em estimativas de baixas temperaturas, mas para a área de estudo desta tese não existem restrições. O erro médio das estimativas de TSMs fornecidas pelo método é de $\sim 1^{\circ} \mathrm{C}$ (Malmgren et al., 2001). 


\subsection{ESTIMATIVAS DE PALEOSSALINIDADE}

As estimativas de paleossalinidade se basearam na aplicação do método residual de isótopos de oxigênio em Globigerinoides ruber (morfotipo white) como em Toledo et al., (2007b). Com algumas variantes, esta abordagem tinha sido anteriormente aplicada para fornecer estimativas de paleossalinidade por Broecker (1989), Duplessy et al. (1991; 1992), Rostek et al. (1993); Maslin et al. (1995); Wang et al. (1995); Martinez et al. (1997); Kroon et al. (1997); Chapman et al. (2000); Sarnthein et al. (2004) e Weldeab et al. (2006). O método se baseia no fato da composição isotópica do carbonato refletir principalmente a temperatura e a composição isotópica da água do mar onde precipita (Emiliani, 1954). Isto significa que, existindo um indicador independente de paleotemperatura (indicador que não se baseie na composição de isótopos de oxigênio como no nosso caso as estimativas baseadas na aplicação das RNAs nos dados das assembléias de foraminíferos planctônicos), é possível excluir o efeito da temperatura do sinal isotópico para obter a composição isotópica de oxigênio da água do mar. Conhecendo a relação existente entre a composição isotópica da água do mar e a salinidade, é possível transformar as estimativas da composição isotópica de oxigênio da água do mar em estimativas de paleossalinidade.

O sinal de paleossalinidade é fortemente influenciado pelo efeito do volume de gelo global o qual é responsável pelo aumento da salinidade em períodos glaciais devido ao acúmulo de água sob a forma de gelo, mas utilizando estimativas do efeito das variações do volume de gelo ao longo do tempo no sinal isotópico da água do mar, é possível filtrar o sinal isotópico antes de convertê-lo em estimativas de paleossalinidade para obter um registro das variações de salinidade independentes do efeito do volume do gelo, as quais podem ser interpretadas como o resultado de mudanças nos regimes de circulação oceânica e atmosférica.

\subsubsection{Análises isotópicas}

Para as análises de isótopos de oxigênio (e carbono) em Globigerinoides ruber (morfotipo white), foram identificadas e separadas em lupa binocular entre 12 e 15 testas por amostra na fração maior que $0,15 \mathrm{~mm}$. As testas foram lavadas em ultrassom com água destilada. 
As análises de isótopos foram feitas pelo Laboratório de Espectrômetro de Massa em Micropaleontologia do Instituto Oceanográfico de Woods Hole (MA, E.U.A.) o qual utiliza um espectrômetro Finnigan MAT252 acoplado a um periférico KIEL-III. A precisão das análises do padrão de carbonato do National Bureau of Standards NBS19 é de $\pm 0,07$ para $\delta^{18} \mathrm{O}$ e $\pm 0,03$ para $\delta^{13} \mathrm{C}$.

\subsubsection{Cálculos}

Para extrair o efeito da temperatura do sinal isotópico foi utilizada uma equação que relaciona a composição isotópica da água do mar com a temperatura existente no momento da calcificação, conhecida como equação de paleotemperatura. Dentre as várias equações de paleotemperatura existentes, optou-se por trabalhar com aquela proposta por Kim e O’Neil (1997) já que, de acordo com Schmidt e Mulitza (2002) esta é a mais apropriada ao se trabalhar com a espécie Globigerinoides ruber (white). De acordo com a equação de Kim e O’Neil (1997):

$T_{\text {iso }}=16.1-4.64\left(\delta^{18} O_{c^{-}} \delta^{18} O_{w}\right)+0.09\left(\delta^{18} O_{c^{-}} \delta^{18} O_{w}\right)^{2}$

Onde $\delta^{18} \mathrm{O}_{\mathrm{c}}$ corresponde à composição isotópica da calcita, $\delta^{18} \mathrm{O}_{\mathrm{w}}$ é a composição isotópica da água do mar e $T_{i s o}$ é a temperatura isotópica. Tendo uma estimativa independente de paleotemperatura (ver seção 4.3), é possível isolar $\delta^{18} \mathrm{O}_{\mathrm{w}}$. Antes disso, é preciso corrigir pela diferença existente entre a $T_{i s o}$ - aquela temperatura esperada de acordo com a composição isotópica das testas dessa espécie - e a temperatura medida ou real $\left(T_{m}\right)$. Esta calibração foi feita por Wang et al. (1995) (eq. 2) através da comparação da composição isotópica de G. ruber nos sedimentos superficiais e os valores correspondentes de TSMs (Levitus, 1982) em baixas latitudes no Atlântico.

De acordo com os autores, os valores de $\delta^{18} \mathrm{O}$ de $G$. ruber $\left(\delta^{18} \mathrm{O}_{\text {ruber }}\right)$ refletem principalmente a temperatura e salinidade de verão no intervalo de 0 a $50 \mathrm{~m}$ de profundidade.

$T_{i s o}=3.147+0.963 * T_{m}$ 
Combinando as equações 1 e 2 e isolando $\delta^{18} \mathrm{O}_{\mathrm{w}}$ temos:

$$
\delta^{18} O_{w}=\delta^{18} \mathrm{O}_{\text {ruber }}-25.78+\sqrt{\left(16.87+0.347 * T_{m}\right)} / 0.18
$$

Para transformar as estimativas de $\delta^{18} \mathrm{O}_{\mathrm{w}}$ em estimativas de paleossalinidade, foi aplicada a relação utilizada por Toledo et al. (2007b):

$$
S S M=1.863^{*} \delta^{18} O_{w}+34.95
$$

Esta equação representa a relação atual entre a salinidade superficial do mar e $\delta^{18} \mathrm{O}_{\mathrm{w}}$ e se baseia em dados de amostras coletadas no Atlântico Sul superficial (profundidade $<250 \mathrm{~m}$ ), entre as latitudes $0-45^{\circ}$. Os dados utilizados para chegar nesta equação incluem amostras do Geochemical Ocean Sections Study (GEOSECS, Östlund et al., 1987), World Ocean Circulation Experiment (WOCE, Meredith et al., 1999), Craig e Gordon (1965) e Pierre et al., (1991).

Combinado as equações 3 e 4 temos:

$$
S S M=34.95+1.863 *\left[\delta^{18} \mathrm{O}_{\text {ruber }}-25.78+\sqrt{\left(16.87+0.347 * T_{m}\right)} / 0.18\right]
$$

Para obter estimativas das variações de paleossalinidade locais, sem a interferência do volume do gelo global, foi extraído o efeito do volume de gelo do valor de $\delta^{18} \mathrm{O}_{\mathrm{w}}$ (eq. 6) de acordo com as estimativas de Labeyrie et al. (1987).

$$
\left.S S M=34.95+1.863 *\left[\delta^{18} \mathrm{O}_{\text {ruber }}-\delta^{18} O_{\text {gelo }}-25.78+\sqrt{\left(16.87+0.347 * T_{m}\right)} / 0.18\right] \quad \text { (eq. } 6\right)
$$

As estimativas de paleossalinidade obtidas através destes cálculos são para o verão, já que as estimativas de paleotemperatura utilizadas são as de verão e os valores de $\delta^{18} \mathrm{O}$ de G.ruber refletem principalmente a TSM do verão (Wang et al., 1995).

O inconveniente do método residual é que ele depende de boas estimativas de (1) paleotemperatura, (2) da relação entre a composição isotópica da água do mar e a salinidade e (3) do efeito do volume de gelo. As incertezas associadas aos dois primeiros itens são os responsáveis pelas elevadas margens de erro do método que 
fazem com que o erro final destas estimativas de SSM seja de em torno de $1.6 \%$ o (Toledo et al, 2007b). Já as incertezas nas estimativas do volume de gelo influem pouco na margem de erro final (Schmidt, 1999) e o erro nas medidas da composição isotópica (ao redor de 0,1\%o, Duplessy et al., 1991) contribui em menor grau para as incertezas das estimativas.

\subsection{ESTIMATIVAS DE PALEOPRODUTIVIDADE}

As estimativas de paleoprodutividade se basearam nos seguintes indicadores:

- Abundância relativa de Globorotalia truncatulinoides (dex);

- Abundância relativa de Neogloboquadrina dutertrei;

- Razão entre as abundâncias relativas das espécies Globigerina bulloides e Globigerinoides ruber (white);

- Abundância relativa de foraminíferos bentônicos;

- Abundância relativa de ostracodes bentônicos; e

- Isótopos de carbono em G.ruber (white) (ver seção 4.4.1.).

Os isótopos de carbono constituem, na realidade, um indicador de fertilidade, ou seja, da disponibilidade de nutrientes (Wefer et al., 1999) enquanto os demais indicadores fornecem diretamente indícios da produtividade, isto é, do fluxo de carbono. Uma vez que nenhum dos indicadores é puramente dependente - e, portanto exclusivamente indicador - de mudanças na paleoprodutividade, eles podem apresentar resultados divergentes. As concordâncias e divergências entre os diversos resultados, assim como as vantagens e limitações de cada indicador, são discutidas em detalhe no capítulo 6.

\subsection{TEOR DE $\mathrm{CaCO}_{3}$ E FLUORESCÊNCIA DE RAIOS X NA FRAÇÃO FINA}

Além dos dados gerados nesta tese, foram incluídos na análise os resultados das análises de Bariani (2009) de teor de $\mathrm{CaCO}_{3}$ e Fluorescência de Raios X (FRX) na fração fina $(<0,063 \mathrm{~mm})$. As análises foram conduzidas em 50 amostras com espaçamento médio de $10 \mathrm{~cm}$ (Fig. 4.1). 
O teor de carbonato foi medido em amostras de $0,25 \mathrm{~g}$ com calcímetro digital automático Petron modelo $\mu \mathrm{R} 10000$.

As análises de FRX foram conduzidas no laboratório de Química e ICP-AES do Instituto de Geociências desta Universidade. Brevemente, a metodologia adotada por Bariani compreendeu as seguintes etapas:

- homogeneização da amostra em almofariz de ágata e pilão do mesmo material;

- secagem em estufa a $100-110^{\circ} \mathrm{C}$ durante $24 \mathrm{~h}$;

- adição do fundente composto por uma mistura de tetraborato e metaborato de lítio na razão $1: 4$;

- nova homogeneização e fundição em máquina de fusão por 30 minutos e

- resfriamento em forma de pastilha.

Para determinar a concentração de cada elemento, a pastilha é exposta à incidência de radiação gama (ou radiação $\mathrm{X}$ ) a qual determina o excitamento de elétrons das moléculas, fazendo com que estes mudem a sua camada de valência. Ao cessar a incidência de radiação sobre a amostra, os elétrons retornam para a antiga camada. Neste processo, cada elemento químico libera uma luz com freqüência característica. A intensidade luminosa de cada freqüência é proporcional à concentração do elemento correspondente na amostra.

\subsection{REANÁLISE DO TESTEMUNHO SAN76}

Em primeiro lugar, o modelo de idade foi reajustado após uma transformação mais precisa das idades de radiocarbono em idades de calendário de acordo com as mesmas técnicas utilizadas para o testemunho KF02. Para a localização do testemunho SAN76, a estimativa de efeito de reservatório é de 263 anos (Butzin et al., 2005, Cao et $a l$., em prep., http://radiocarbon.LDEO.columbia.edu/ ). A única diferença em relação ao método empregado na construção do modelo de idade do testemunho KF02 foi a utilização de dados de isótopos de oxigênio em foraminíferos bentônicos ao invés de planctônicos, por se tratar de um sinal mais "limpo" e livre da variabilidade de maior freqüência característica dos dados de superfície. As análises em bentônicos foram feitas em espécimes do gênero Cibicidoides.

As estimativas de paleotemperatura do SAN76 de Toledo (2000) e Toledo et al. (2007a, 2007b) se baseavam na aplicação da Técnica do Análogo Moderno (Hutson, 1980) com Índice de Similaridade (SIMMAX; Pflaumann et al., 1996, 2003). Esta 
técnica permite reconstruir paleotemperaturas superficiais procurando por análogos de assembléias fósseis, dentro de uma base de dados modernos. As paleotemperaturas são estimadas como a média da temperatura de um número pré-determinado de análogos modernos escolhidos de acordo com um índice de similaridade o qual confere um peso maior aos análogos geograficamente mais próximos à amostra fóssil. Devido às vantagens das RNAs, foram obtidas novas estimativas usando esta nova técnica. Com as novas estimativas de idade e paleotemperatura das amostras foram recalculados os efeitos do volume de gelo e as estimativas de paleossalinidade seguindo a mesma metodologia descrita para o testemunho KF02. 


\section{RESULTADOS}

A apresentação dos resultados foi dividida por testemunhos. Os resultados do testemunho KF02 são apresentados na seção 5.1 e os resultados da reanálise do testemunho SAN76 são detalhados na seção 5.2. Na seção 5.3 os resultados de ambos os testemunhos são apresentados em conjunto. Para auxiliar a visualização, foram utilizados tons de azul para os resultados do testemunho KF02 e tons de vermelho para o testemunho SAN76.

\subsection{TESTEMUNHO KF02}

Primeiramente é apresentada a descrição do testemunho já proporcionada pela Petrobras na seção 5.1.1. Nas seções subsequientes, de 5.1.2 até 5.1.8 são apresentados respectivamente os resultados de modelo de idade, censos de fauna, isótopos estáveis, estimativas de paleotemperatura, paleossalinidade e paleoprodutividade e resultados das análises de Bariani (2009) na fração fina.

\subsubsection{Descrição do testemunho}

A Fig. 5.1 apresenta a descrição e as fotografias do testemunho KF02. De acordo com a descrição inicial do testemunho, a maior parte dele compreende a Biozona $\mathrm{Z}$ de Ericson e Wollin (1968), rica em G. menardii e correspondente ao Holoceno. Neste testemunho trata-se de lama (argila siltosa) levemente carbonática (teor de carbonato entre 5 e 18\%), de cor cinza olivácea a qual grada para uma lama cinza esverdeada rica em carbonato (com teor de carbonato entre 18 e 30\%). Abaixo dos $300 \mathrm{~cm}$ de profundidade o testemunho apresenta areia siltosa bioturbada dispersa na matriz. Esta areia fina a muito fina, que se apresentou mais concentrada entre 315 e $415 \mathrm{~cm}$ de profundidade é siliciclástica com bioclastos. Os sedimentos abaixo de $380 \mathrm{~cm}$ de profundidade pertencem à zona Y, pobre em G. menardii. 


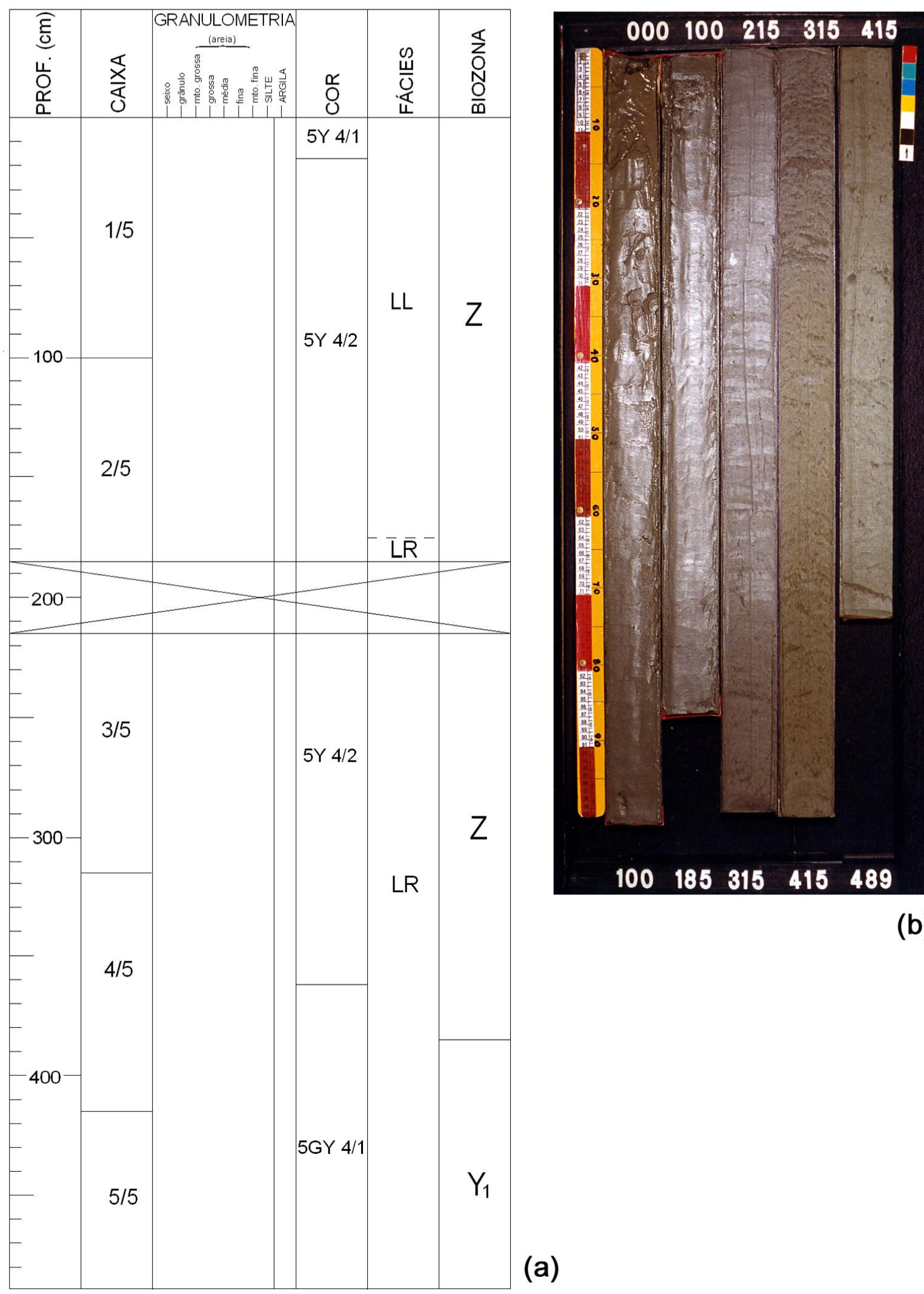

Fig. 5.1. Descrição (a) e fotos (b) do testemunho KF02. Legenda: LL = Lama (argila siltosa) levemente carbonática de cor cinza olivácea gradando para LR = lama cinza esverdeada rica em carbonato. Cores de acordo com a classificação de cores de Munsell. Biozonas de acordo com Ericson e Wollin (1968) 


\subsubsection{Modelo de idade}

A Tabela 5.1 e a Fig. 5.2 apresentam as idades de ${ }^{14} \mathrm{C}$ das amostras datadas e as suas respectivas idades calendário após a correção pelo efeito de reservatório de 271 anos. A idade estimada da amostra do topo $(2 \mathrm{~cm})$ foi de aproximadamente 400 anos o que, dadas as elevadas taxas de sedimentação do testemunho (ver seção 5.1.2.1), significa que houve uma perda do topo do testemunho, o que é freqüente durante a operação de amostragem com pistão (Damuth, 1977).

Tabela 5.1. Datações de radiocarbono e respectivas estimativas de idades calendário para o testemunho KF02.

\begin{tabular}{|c|c|c|c|c|c|c|}
\hline $\begin{array}{c}\text { Prof. } \\
\text { da } \\
\text { amostra } \\
(\mathrm{cm})\end{array}$ & Espécie analisada & $\begin{array}{l}\text { Idade }{ }^{14} \mathrm{C} \\
\left(10^{3} \text { anos }\right)\end{array}$ & $\begin{array}{l}\text { Erro } \\
(\text { anos } \\
\left.{ }^{14} \mathrm{C}\right)\end{array}$ & $\begin{array}{c}\text { Idade }{ }^{14} \mathrm{C} \\
\text { corrigida } \\
\text { pelo efeito } \\
\text { de } \\
\text { reservatório } \\
\left(10^{3} \text { anos }\right)\end{array}$ & $\begin{array}{c}\text { Idade } \\
\text { calendário } \\
\left(1^{3} \text { anos }\right. \\
\text { A.P. })\end{array}$ & $\begin{array}{c}\text { Erro } \\
\text { (anos } \\
\text { calendário) }\end{array}$ \\
\hline 2 & G.menardii e G.ruber & 615 & 30 & 344 & 404 & 57 \\
\hline 45 & G. ruber & 850 & 15 & 579 & 579 & 34 \\
\hline 99 & G. ruber & 1080 & 50 & 809 & 720 & 41 \\
\hline 149 & G. ruber & 2910 & 20 & 2639 & 2750 & 9 \\
\hline 234 & G. ruber & 5230 & 25 & 4959 & 5673 & 30 \\
\hline 318 & G. ruber & 7750 & 30 & 7479 & 8319 & 39 \\
\hline 360 & G. ruber & 9660 & 60 & 9389 & 10611 & 78 \\
\hline 420 & G. ruber & 10550 & 60 & 10279 & 12048 & 102 \\
\hline 436 & G. ruber & 11150 & 40 & 10879 & 12776 & 45 \\
\hline
\end{tabular}

A Fig. 5.3 apresenta a correlação entre a curva de isótopos de oxigênio em $G$. ruber (white) e a curva do SPECMAP (Martinson et al., 1987). A partir desta correlação e das datações de radiocarbono como pontos de controle, foram obtidas as idades das amostras do testemunho. Desconsiderando o intervalo não amostrado, o modelo de idade indica que o tempo médio entre amostras consecutivas no testemunho é de aproximadamente 64 anos. Já o tempo mínimo entre amostras chegou a cinco anos no topo do testemunho e o tempo máximo, foi de 273 anos em uma amostra próxima à base do testemunho. 


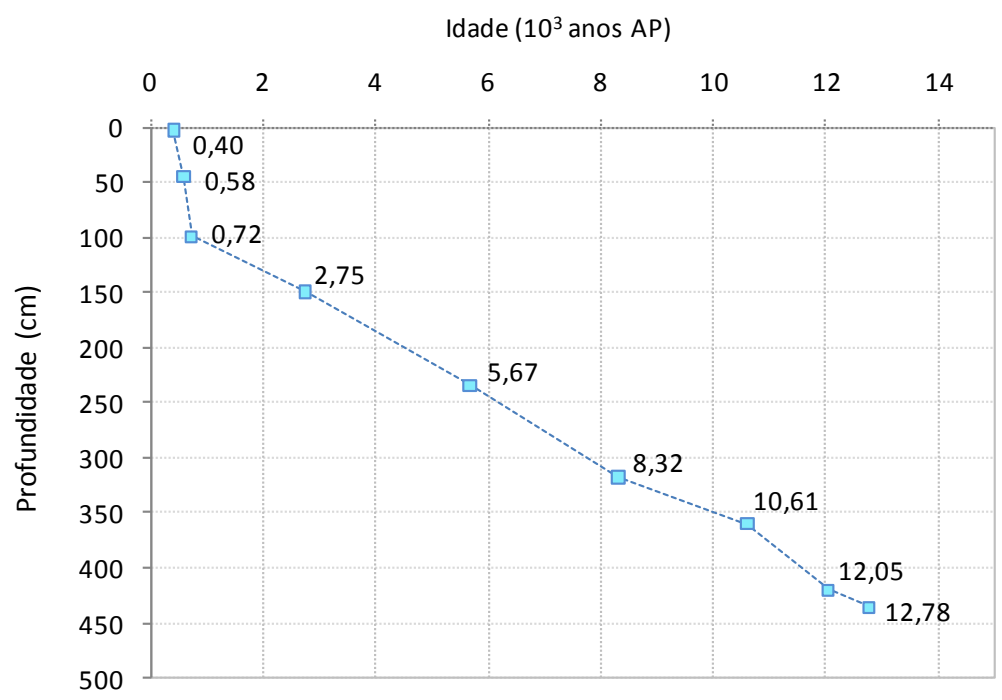

Fig. 5.2. Relação entre profundidade e idade das amostras.

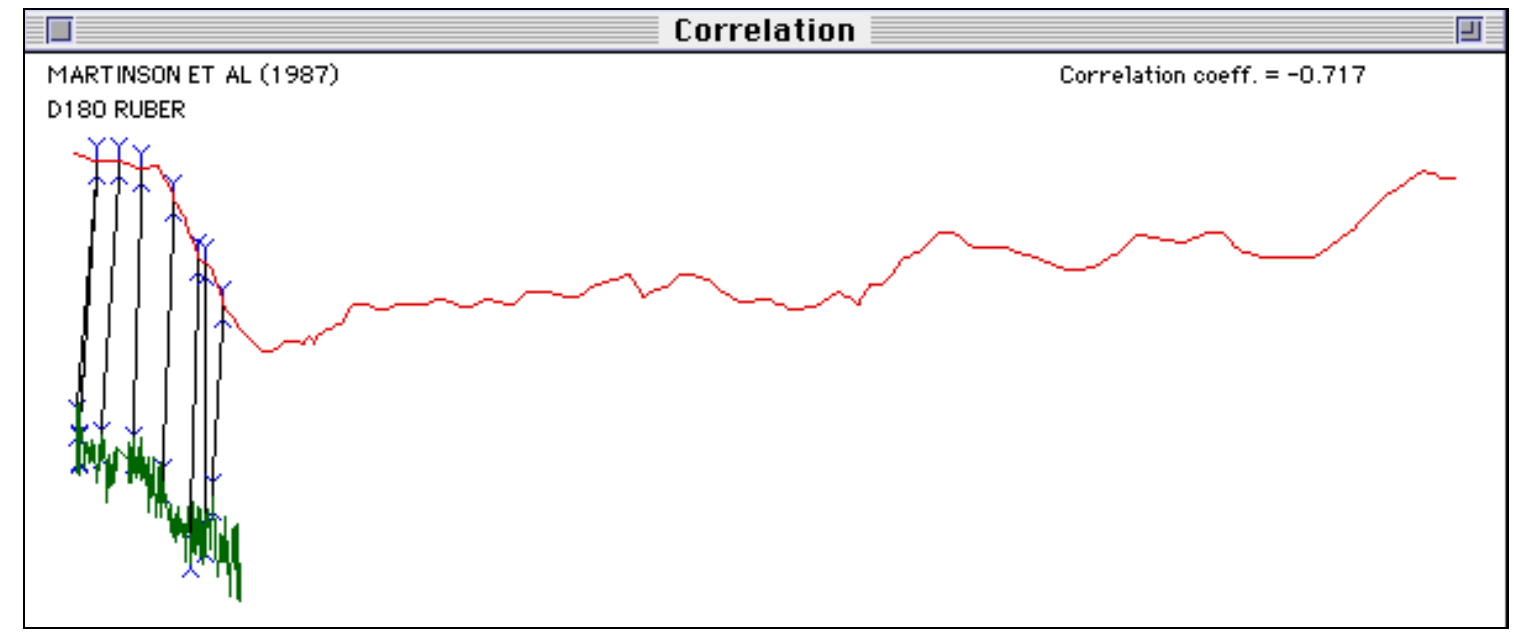

Fig. 5.3. Correlação entre a curva do SPECMAP (Martinson et al., 1987) e a curva de isótopos de oxigênio em G.ruber (white) feita com o programa AnalySeries (Paillard et al., 1996).

\subsubsection{Taxas de sedimentação}

As datações de radiocarbono sugerem taxas de sedimentação muito elevadas ao longo do testemunho, mas principalmente na seção próxima ao topo onde os valores chegaram a mais de $500 \mathrm{~cm} / 10^{3}$ anos (Fig 5.4). A taxa média de sedimentação ao longo do testemunho foi de $97 \mathrm{~cm} / 10^{3}$ anos. 

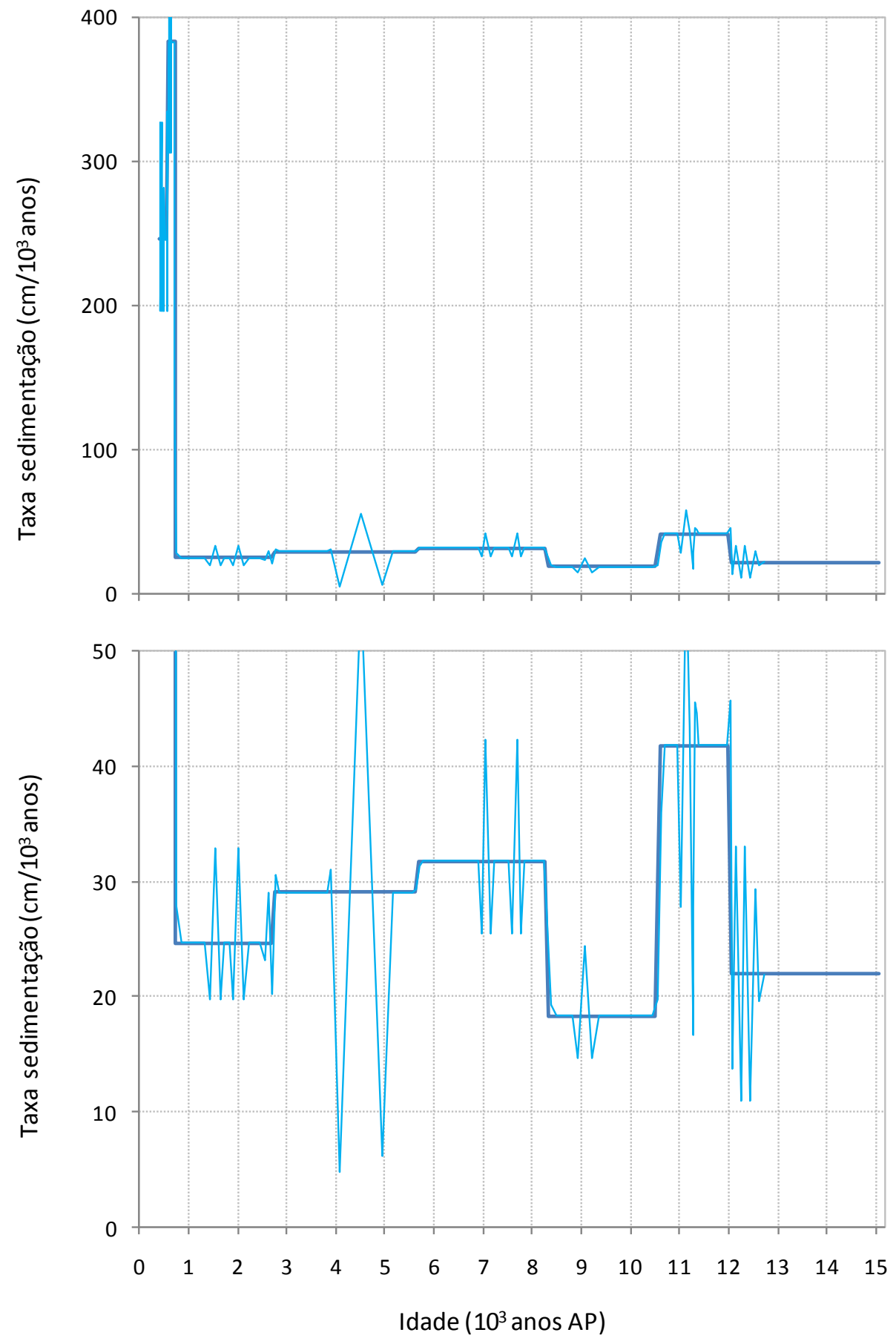

Fig. 5.4. Estimativas de taxas de sedimentação para o testemunho KF02. A linha azul clara indica a taxa de sedimentação de acordo com as idades estimadas para cada amostra analisada do testemunho enquanto a linha azul escura corresponde à taxa de sedimentação estimada assumindo taxas de sedimentação constantes entre datações consecutivas. A escala vertical do gráfico superior foi dimensionada de maneira a mostrar os dados de todo o testemunho enquanto no gráfico inferior a escala vertical foi reduzida para ampliar e observar melhor as variações na taxa de sedimentação. 


\subsubsection{Censos de fauna}

Foi identificado um total de 35 espécies e morfotipos, de foraminíferos planctônicos (Tabela 5.2). As abundâncias mínimas, médias e máximas de cada um estão listadas na Tabela 5.3. A espécie mais abundante ao longo de todo o testemunho foi Globigerinoides ruber em seus dois morfotipos (white e pink). Outras espécies tiveram abundâncias relativas significativas, mas variando em importância ao longo do tempo. Além dos dois morfotipos de G. ruber, as espécies que apresentaram abundâncias relativas máximas maiores do que 10\% foram: Globigerinita glutinata (até 22,4\%), Globigerina bulloides (até 15,2\%), Globigerinella calida (até 10,7\%), Globigerinoides sacculifer quando considerados os espécimes com e sem saco (até $10,7 \%$ ) e Globorotalia truncatulinoides (dextrógira) (10,59\%).

As variações na abundância relativa destas espécies ao longo do testemunho são apresentadas na Figura 5.5 junto com as variações na abundância do Plexo menardiforme o qual constitui um importante indicador de períodos interglaciais. Como neste testemunho as amostras interglaciais são holocênicas, o Plexo inclui as espécies $G$. menardii, G. tumida, G. fimbriata e G. ungulata. Na Fig. 5.6, são apresentadas as abundâncias relativas das espécies que compõem o Plexo. Observa-se que, na grande maioria, trata-se de espécimes de G. menardii e, secundariamente, G. tumida. As espécies G. fimbriata e G. ungulata pouco contribuem na composição da fauna. Já, $G$. menardii e G. tumida apresentam um comportamento semelhante, com dois períodos distintos de máxima abundância. O primeiro, logo após um aumento brusco em torno de 8 mil anos AP por aproximadamente 2 mil anos e o outro no final do Holoceno, após um mínimo no Holoceno ocorrido há aproximadamente 2 mil anos. As abundâncias relativas de G. fimbriata e G. ungulata, embora pequenas, sugerem um aparecimento posterior à G. menardii e G. tumida, somente do Holoceno médio em diante. 
Tabela 5.2. Lista das espécies e morfotipos identificados nos censos de fauna do testemunho KF02 (ver anexo).

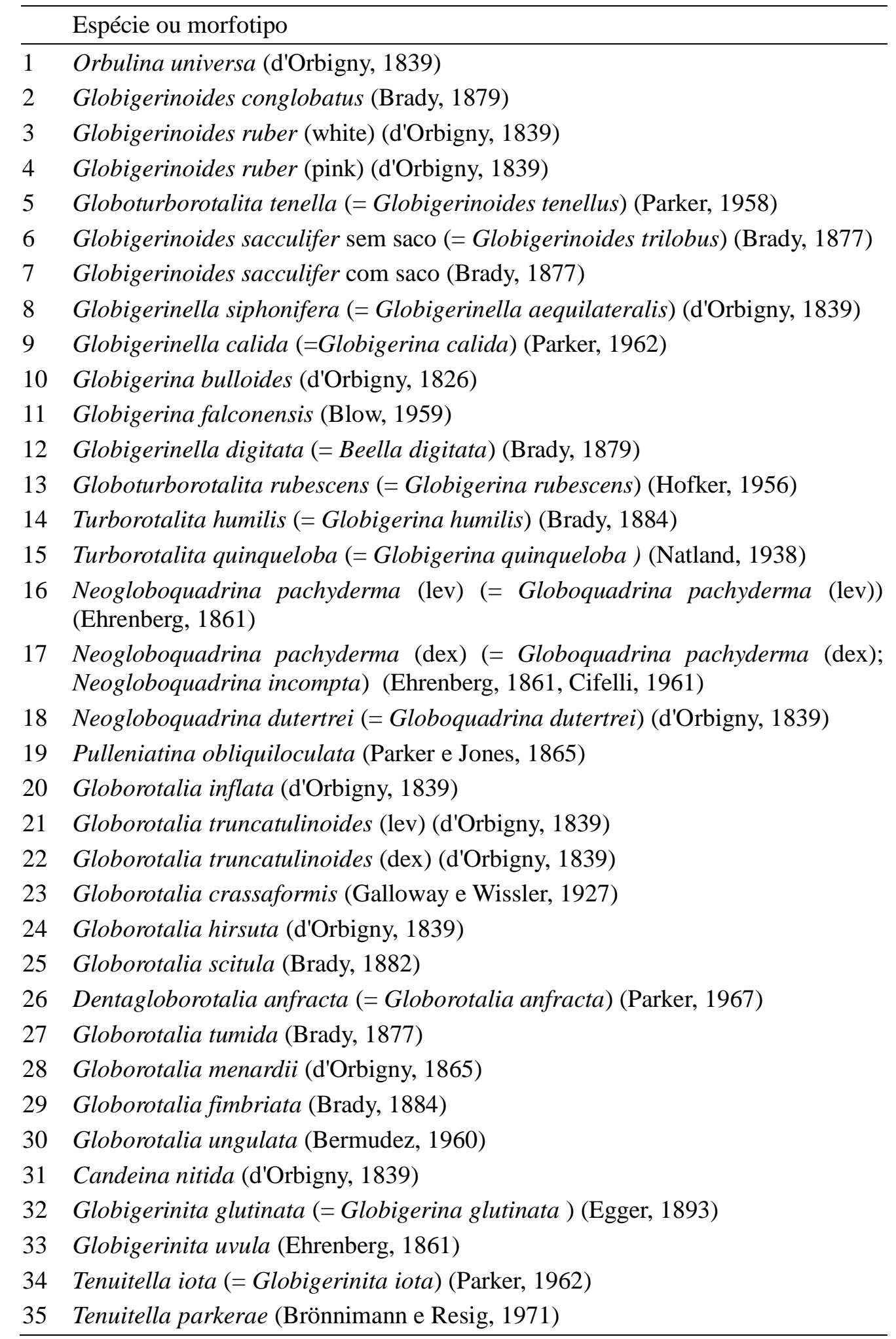


Tabela 5.3. Abundâncias relativas mínimas, médias e máximas das espécies identificadas ao longo do testemunho KF02. Espécies listadas de acordo com as suas abundâncias relativas.

\begin{tabular}{|c|c|c|c|}
\hline \multirow[b]{2}{*}{ Espécie ou morfotipo: } & \multicolumn{3}{|c|}{ Abundâncias relativas (\%) } \\
\hline & Mínima & Média & Máxima \\
\hline G. ruber (white) & 24,21 & 38,78 & 54,64 \\
\hline G. ruber (pink) & 4,56 & 13,45 & 28,82 \\
\hline G. glutinata & 6,86 & 14,80 & 22,38 \\
\hline G. bulloides & 3,28 & 8,30 & 15,24 \\
\hline G. calida & - & 3,90 & 10,67 \\
\hline G. truncatulinoides (dex) & - & 2,48 & 10,59 \\
\hline G. sacculifer sem saco & 0,86 & 3,20 & 8,54 \\
\hline N. dutertrei & - & 1,26 & 8,53 \\
\hline G. menardii & - & 2,42 & 7,81 \\
\hline O. universa & - & 1,18 & 7,21 \\
\hline G. rubescens & - & 1,40 & 5,92 \\
\hline G. tenella & 0,28 & 1,77 & 5,06 \\
\hline G. inflata & - & 0,71 & 4,44 \\
\hline P. obliquiloculata & - & 0,34 & 3,48 \\
\hline G. siphonifera & - & 1,18 & 3,30 \\
\hline G. hirsuta & - & 0,63 & 3,21 \\
\hline G. sacculifer com saco & - & 0,83 & 2,87 \\
\hline G. tumida & - & 0,61 & 2,67 \\
\hline G. crassaformis & - & 0,40 & 2,41 \\
\hline G. conglobatus & - & 0,62 & 2,40 \\
\hline N. pachyderma (dex) & - & 0,29 & 2,11 \\
\hline G. scitula & - & 0,40 & 1,81 \\
\hline C. nitida & - & 0,07 & 1,32 \\
\hline G. quinqueloba & - & 0,17 & 1,20 \\
\hline G. falconensis & - & 0,31 & 1,15 \\
\hline G. fimbriata & - & 0,09 & 0,88 \\
\hline G. truncatulinoides (lev) & - & 0,09 & 0,70 \\
\hline G. anfracta & - & 0,07 & 0,67 \\
\hline N. pachyderma (lev) & - & 0,04 & 0,64 \\
\hline G. humilis & - & 0,04 & 0,64 \\
\hline G. ungulata & - & 0,04 & 0,58 \\
\hline T. iota & - & 0,03 & 0,40 \\
\hline T. parkerae & - & 0,02 & 0,33 \\
\hline G. digitata & - & 0,01 & 0,33 \\
\hline G. uvula & - & 0,03 & 0,33 \\
\hline
\end{tabular}



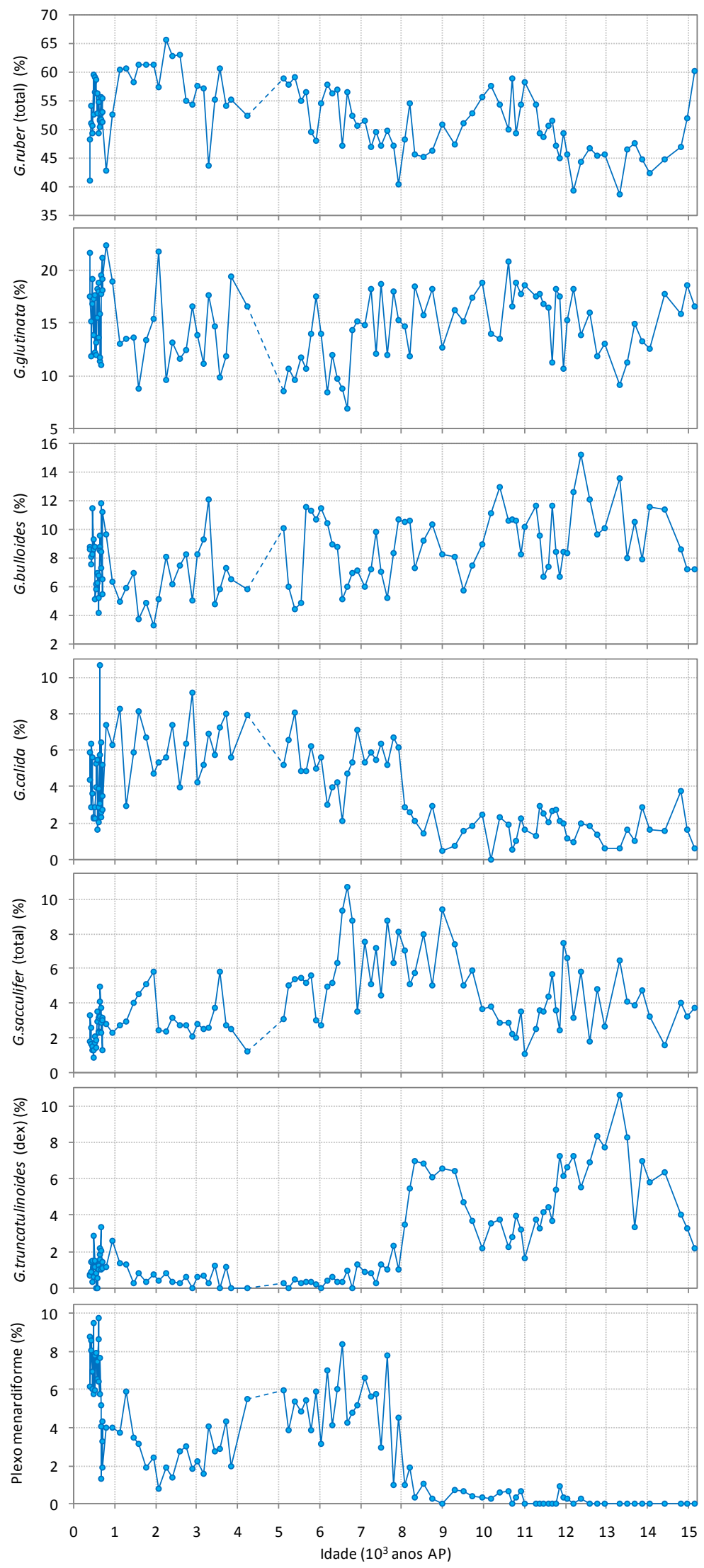

Fig. 5.5. Abundâncias relativas das espécies mais abundantes ao longo do testemunho KF02. As escalas variam de um gráfico a outro para facilitar a visualização. $\mathrm{O}$ trecho não analisado, compreendido entre 185 e $215 \mathrm{~cm}$ de profundidade, está representado pela linha pontilhada. 

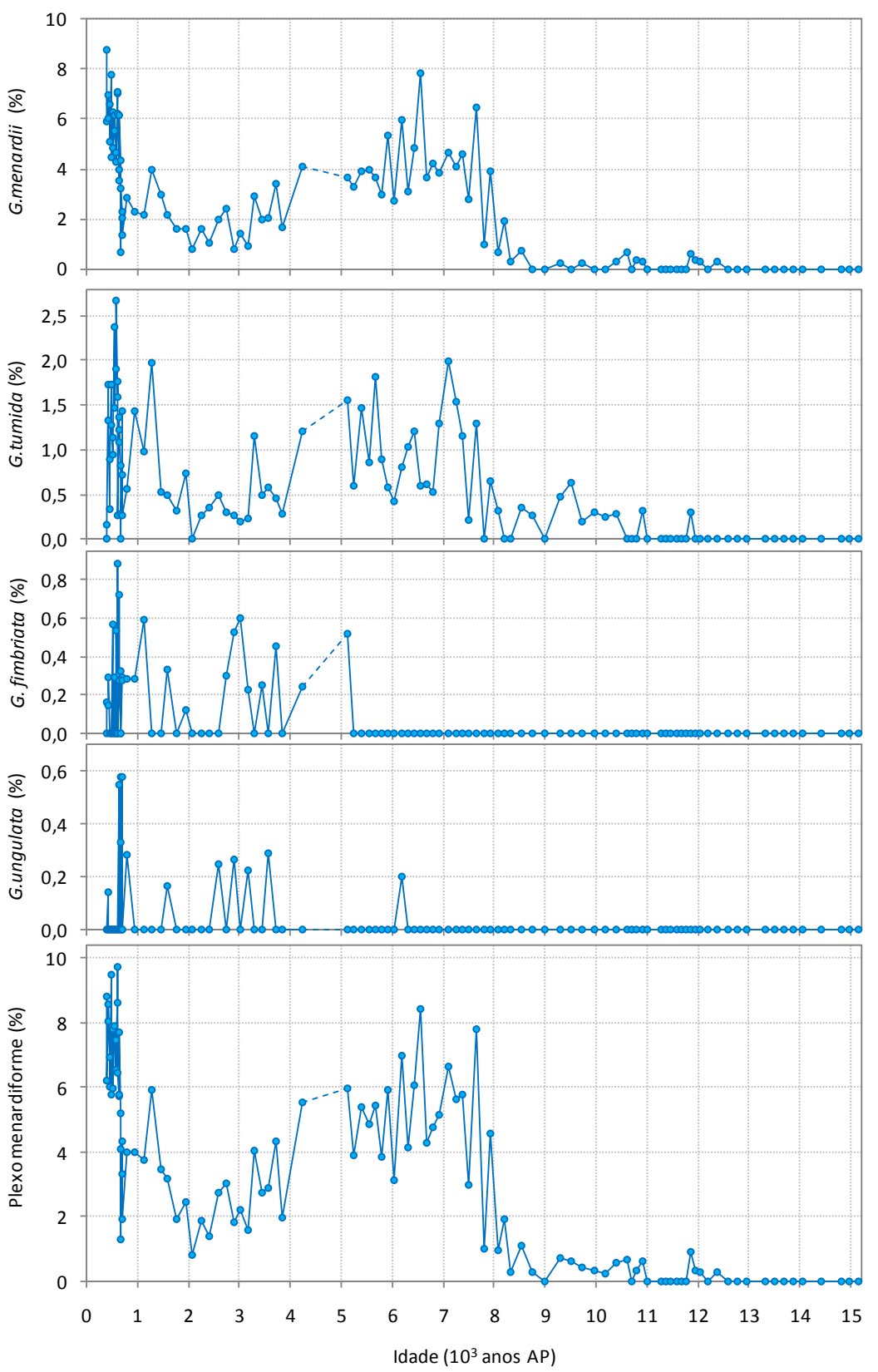

Fig. 5.6. Abundâncias relativas das espécies que compõem o Plexo menardiforme ao longo do testemunho KF02. Escalas verticais variáveis para auxiliar a visualização.

Não foram observadas as duas subzonas da biozona $\mathrm{Z}$ propostas por Vicalvi (1997) para a Bacia de Campos de acordo com as variações na abundância relativa do Plexo menardiforme. Segundo o autor, a abundância relativa no início do Holoceno (Z2) ficaria entre 1 e $3 \%$ passando para 3 a $7 \%$ na subzona $\mathrm{Z1}$, refletindo o progressivo aquecimento do Atlântico após o Máximo Glacial. Em trabalho na Bacia de Santos, Portilho Ramos et al. (2006) também não identificaram as subzonas de Vicalvi, embora os resultados destes autores não fossem conclusivos uma vez que além da taxa de sedimentação do testemunho analisado ser muito baixa no Holoceno, apenas duas 
amostras pertenciam ao intervalo de interesse. Diferentemente das subzonas propostas por Vicalvi, no testemunho KF02 foram identificados um período no início do Holoceno com abundâncias menores que $1 \%$, seguido de um rápido aumento para abundâncias maiores do que $3 \%$ entre 8 e 4 mil anos AP, seguido de um novo decréscimo na abundância até $0,8 \%$ em torno de 2 mil anos AP e, finalmente, um novo aumento até valores entre 6 e quase $10 \%$ nas amostras do topo do testemunho.

Os dois morfotipos de G. ruber foram considerados em conjunto na Fig. 5.5. Já na Fig. 5.7, são apresentadas as variações por morfotipo e observa-se que, de maneira geral, as abundâncias relativas de ambos morfotipos apresentaram uma correlação negativa e que a variante white foi muito mais abundante do que a variante pink. A única exceção é em torno de 700 anos AP, quando a variante pink apresentou uma abundância relativa maior do que a de white. Os resultados dão suporte à idéia de Deuser e Ross (1989) de que o morfotipo pink ocupa o nicho ecológico parcialmente liberado pelo morfotipo white.

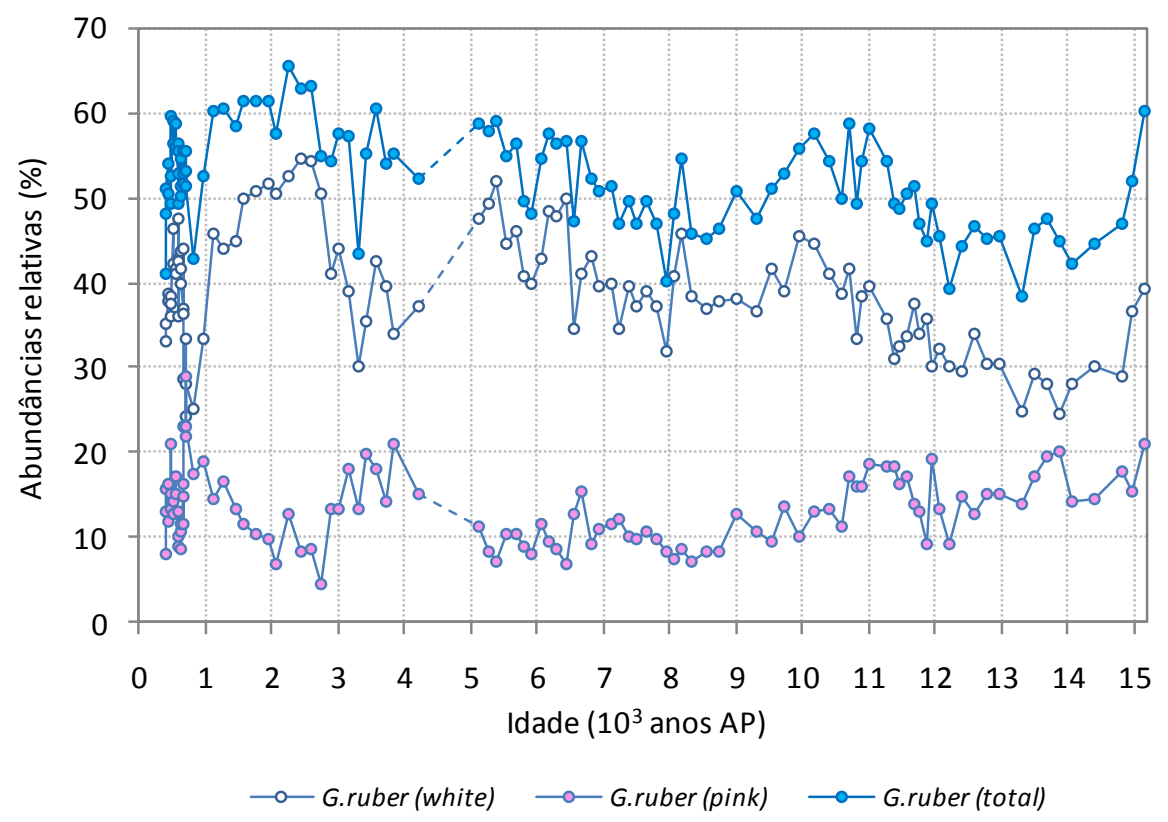

Fig. 5.7. Abundâncias relativas dos dois morfotipos de G. ruber no testemunho KF02.

Os dois tipos de G. sacculifer, com e sem saco, também foram plotados individualmente na Fig. 5.8. Observa-se que a grande maioria corresponde a espécimes sem saco. Tanto os espécimes sem saco como os com saco apresentam as maiores abundâncias na primeira metade do Holoceno, embora neste período também a amplitude de variação das abundâncias relativas seja maior. 


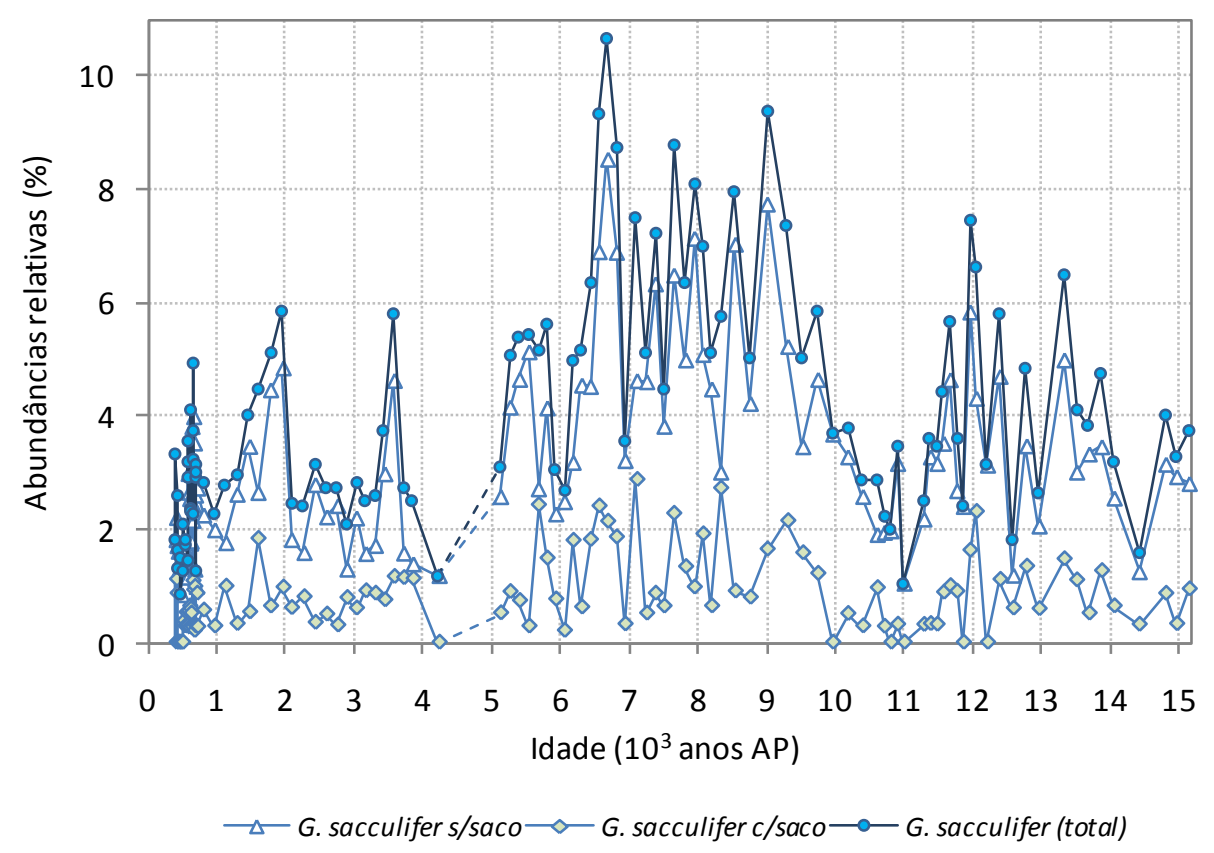

Fig. 5.8. Abundâncias relativas de G. sacculifer com e sem saco e a soma de ambos os tipos ao longo do testemunho KF02.

A Fig. 5.9 apresenta as abundâncias relativas de espécies com abundâncias máximas entre 3,2\% (G. hirsuta) e 8,5\% (N. dutertrei). Assim como verificado por Vicalvi (1997) para a Bacia de Campos, G. inflata é rara ou ausente no Holoceno. Observa-se que esta espécie, junto com G. truncatulinoides (dex) e $N$. dutertrei apresenta um comportamento oposto ao apresentado pelo Plexo menardiforme, com máximas abundâncias na seção do testemunho anterior a 8 mil anos AP. Embora $G$. rubescens também tenha apresentado de maneira geral maiores abundâncias antes do início do Holoceno, esta espécie também apresentou abundâncias significativas em torno de 8 e 3 mil anos AP. As demais espécies da figura não apresentam um padrão claro de variação.

Na Fig. 5.10 são apresentadas as abundâncias relativas de espécies pouco representadas ao longo do testemunho (abundâncias máximas menores do que 2,4\%). Exceto por $N$. pachyderma (dex) e G. crassaformis que apresentaram maiores abundâncias na deglaciação, as demais espécies não apresentaram um padrão claro de variação. As variações na abundância das espécies T. humilis, $N$. pachyderma (lev), D. anfracta, G. digitata, T. iota, T. parkerae e G. uvula não foram plotadas já que estas espécies apresentaram, no máximo, dois espécimes por amostra. 

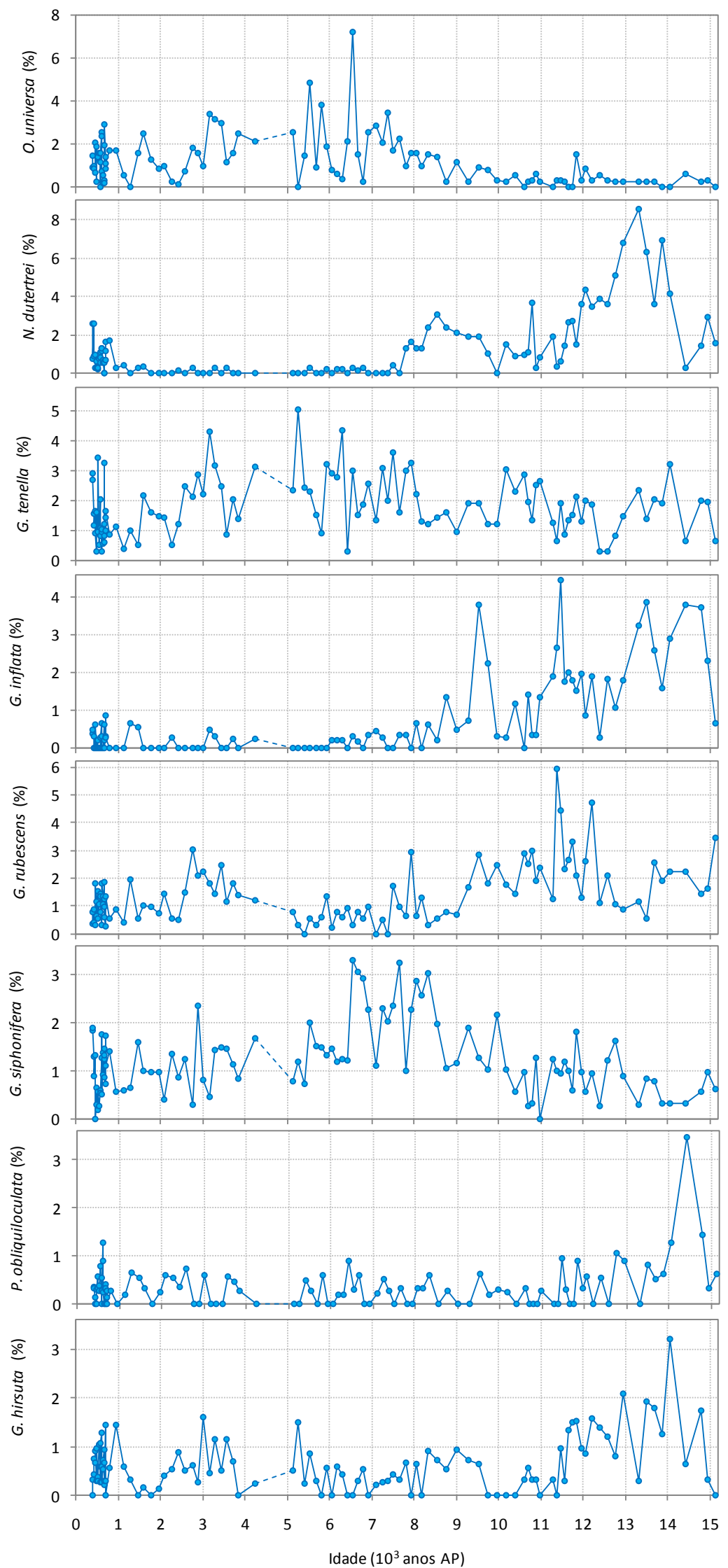

Fig. 5.9. Abundâncias relativas de espécies com abundâncias máximas entre 3,2 \% (G. hirsuta) e $8,5 \%$ (N. dutertrei) ao longo do testemunho KF02. 

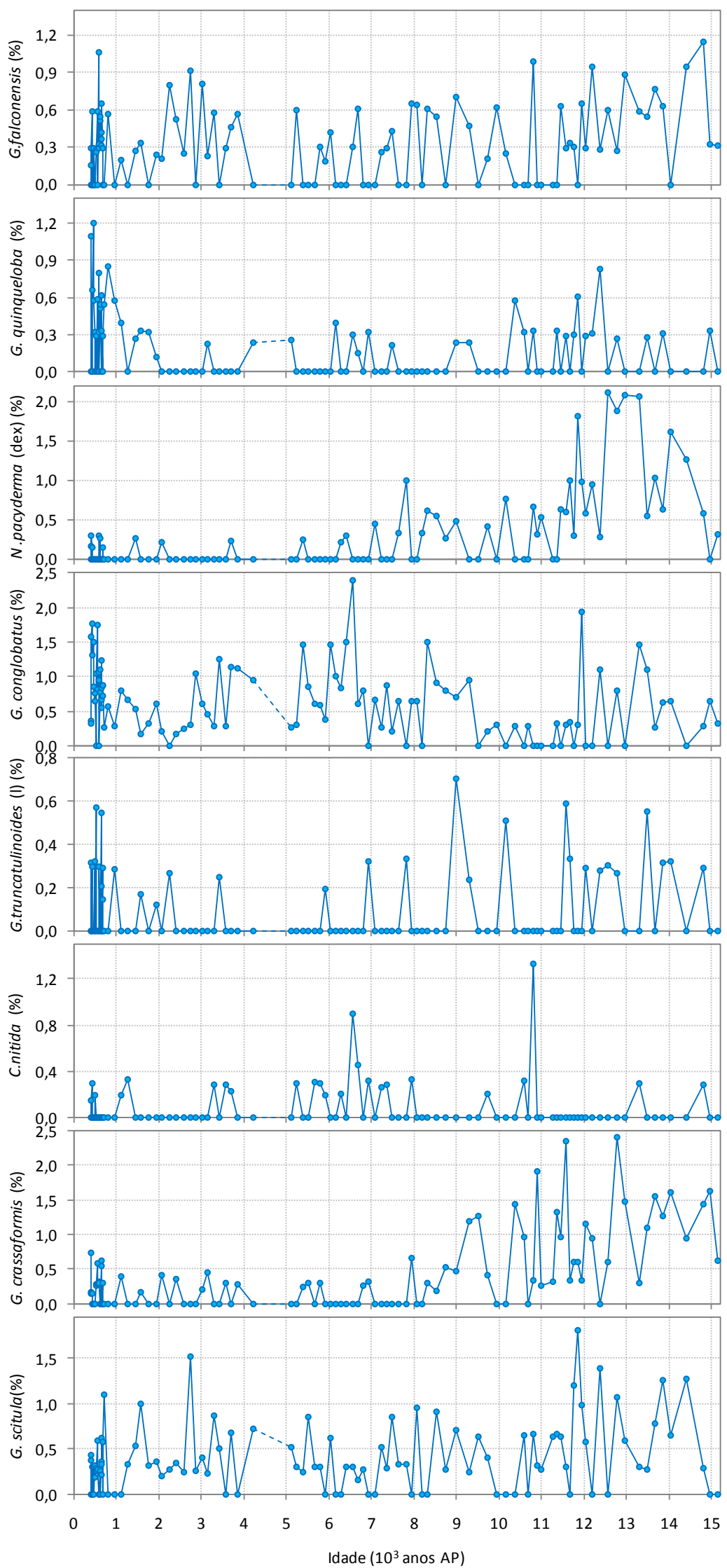

Fig. 5.10. Abundâncias relativas de espécies com abundâncias máximas menores que 2,4 \% ao longo do testemunho KF02. 
Nos censos de fauna, foram contabilizados também os fragmentos de foraminíferos planctônicos. As variações na abundância relativa de fragmentos em relação ao total de foraminíferos planctônicos são apresentadas na Fig. 5.11. Não foram observadas tendências temporais claras ao longo do testemunho, mas os valores apontam para uma grande variabilidade no início do Holoceno, quando ocorreram os valores máximo e mínimo.

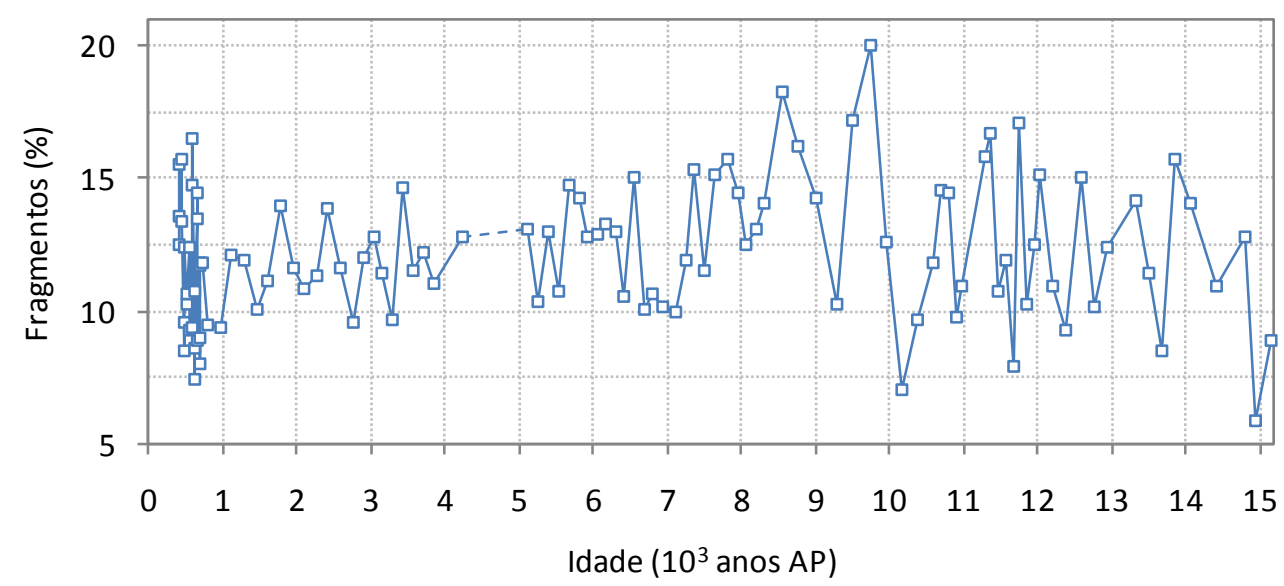

Fig. 5.11. Percentagem de fragmentos de foraminíferos planctônicos em relação ao total de foraminíferos planctônicos ao longo do testemunho KF02.

\subsubsection{Isótopos estáveis}

A Fig. 5.12 apresenta os resultados das análises de isótopos de oxigênio em rocha total e em G.ruber (white). Em ambas as curvas se observa a tendência de uma progressiva diminuição dos valores em direção ao recente. Como esperado, os valores médios em rocha total são superiores aos valores dos planctônicos (Azevedo et al., 1997).

A amplitude de variação dos valores isotópicos é maior nas amostras de rocha total do que nas amostras de G. ruber. No caso das últimas, o sinal isotópico constitui fundamentalmente uma combinação dos efeitos de variações isotópicas da água do mar e da temperatura superficial. Já no caso das amostras de rocha total, a amplitude dos sinais tanto de composição isotópica como de temperatura sofrem uma maior variação pela mistura entre material planctônico de diversas profundidades e material bentônico. Como o material bentônico calcifica em águas mais frias e com uma variabilidade 
térmica pequena, os seus valores isotópicos tendem a serem maiores e mais estáveis que os valores de planctônicos.

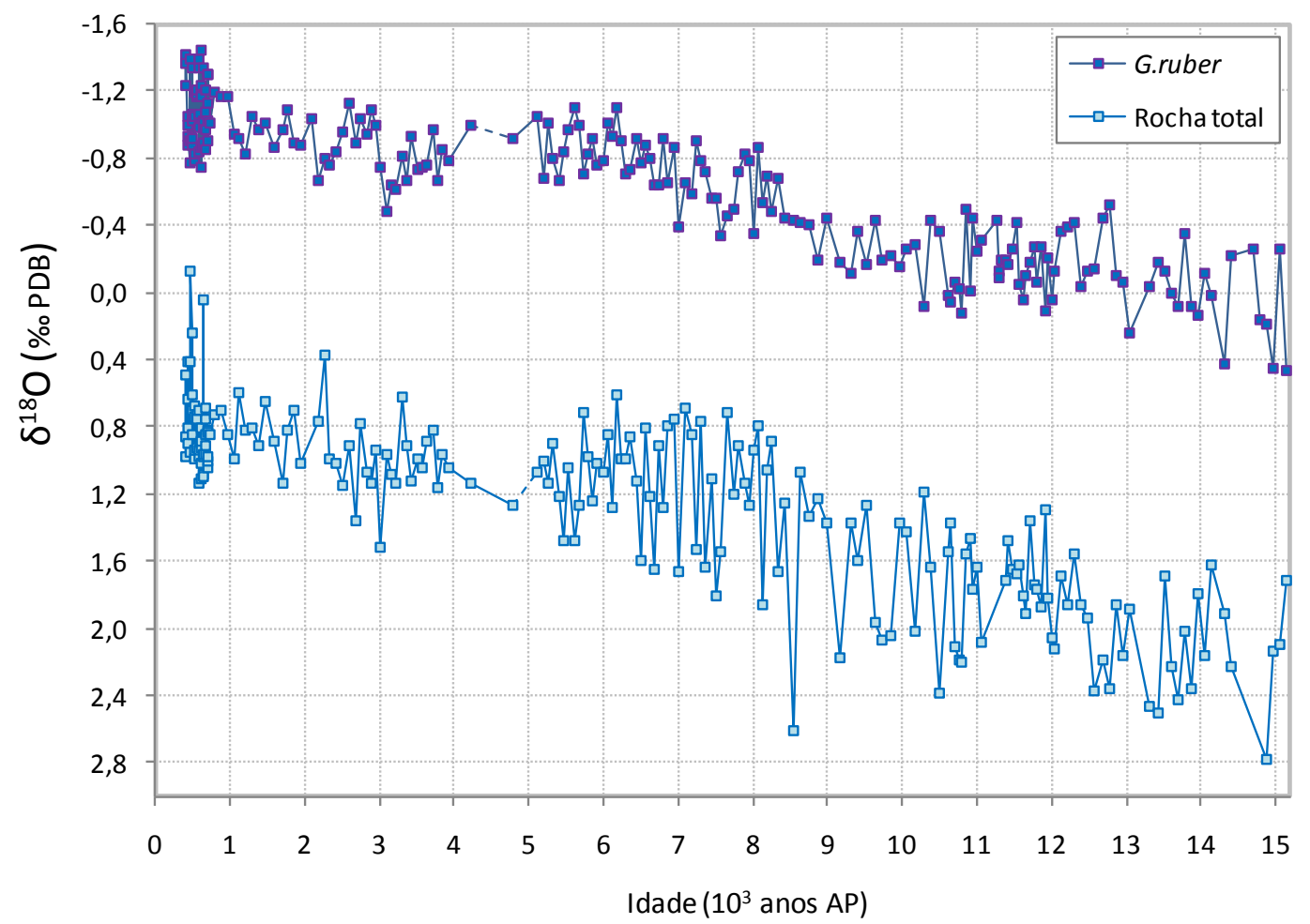

Fig. 5.12. Isótopos de oxigênio em rocha total (abaixo) e G. ruber (white) (acima). A escala de $\delta^{18} \mathrm{O}$ está invertida, de acordo com o convencionado em estudos paleoceanográficos. Valores em PDB.

A Fig. 5.13 apresenta os resultados de isótopos de carbono também em rocha total e em G. ruber (white). Observa-se uma maior variabilidade e amplitude de valores isotópicos no caso dos dados de $\delta^{13} \mathrm{C}$ em $G$. ruber, comparados aos de rocha total. Por existirem muito mais parâmetros envolvidos na determinação desta razão isotópica, a correlação entre os dados de G. ruber e os dados de rocha total que integram o sinal de organismos planctônicos e bentônicos é muito menor do que no caso de isótopos de oxigênio. De acordo com cálculos feitos com o programa AnalySeries, enquanto o coeficiente de correlação entre as curvas de isótopos de oxigênio em $G$. ruber e rocha total era igual a 0,726 , no caso das curvas de isótopos de carbono o coeficiente de correlação é de apenas 0,177 . 


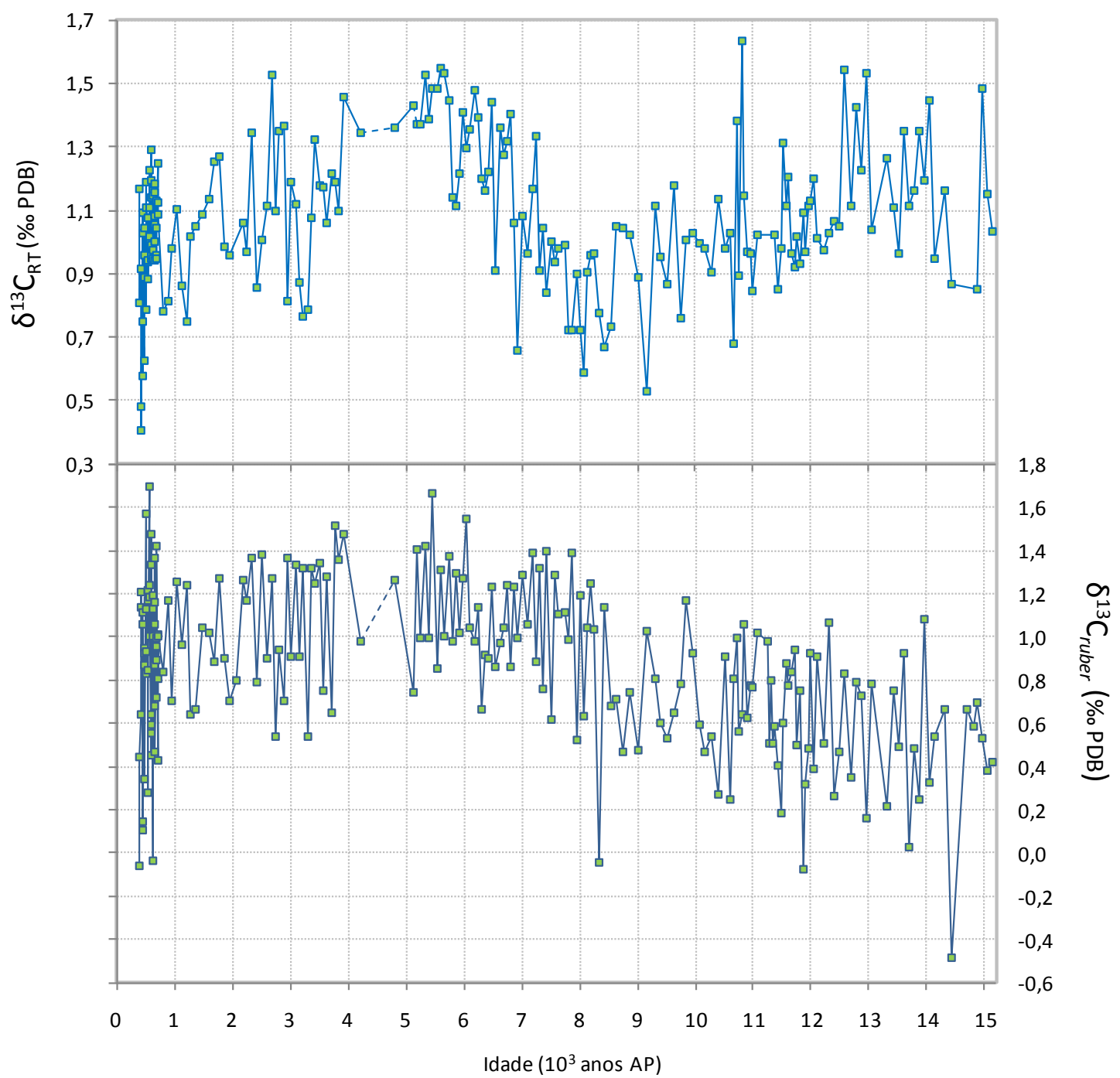

Fig. 5.13. Isótopos de carbono em rocha total (acima) e G. ruber (white) (abaixo). Valores em PDB.

\subsubsection{Estimativas de paleotemperatura}

A Fig. 5.14 apresenta as estimativas de TSM de verão, inverno e média anual, assim como a diferença entre as estimativas de inverno e verão. Os desvios padrão das estimativas de paleotemperatura estão dentro do previsto o que significa que, dentre as amostras analisadas, não houve casos significativos de não-análogos (Dr. Michal Kucera, comunicação pessoal). De maneira geral, as estimativas de médias anuais parecem ser as mais confiáveis devido aos menores desvios. A média do desvio padrão das estimativas de TSM anual foi de $0,49^{\circ} \mathrm{C}$, muito próximo do valor do desvio das estimativas de TSM de verão que foi de $0,54^{\circ} \mathrm{C}$. Já os desvios das estimativas de inverno foram significativamente maiores, com valor médio de $0,91^{\circ} \mathrm{C}$ (Tabela 5.4). 


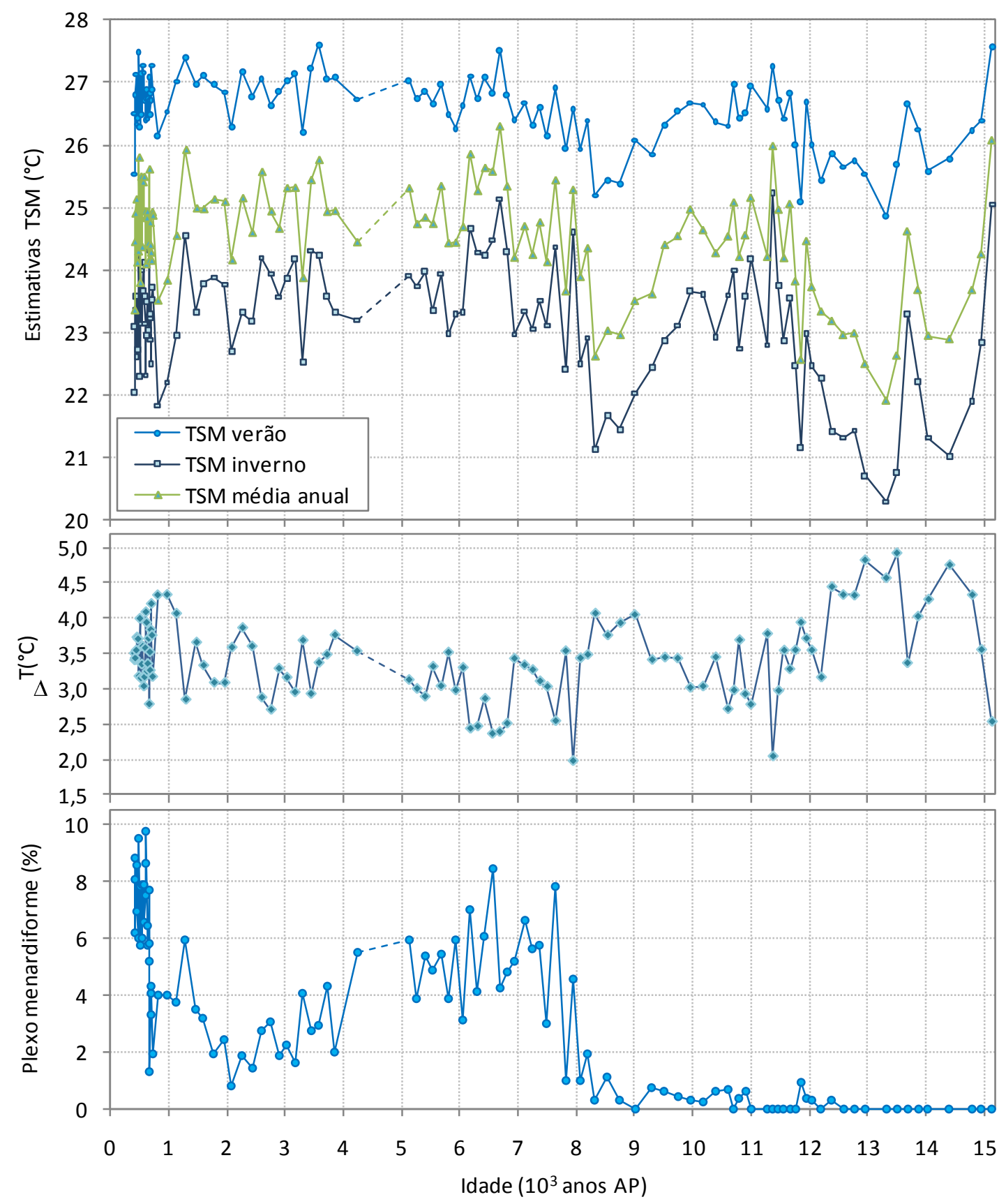

Fig. 5.14. Estimativas de paleotemperatura de verão, inverno e média anual obtidas para o testemunho KF02 através da aplicação da técnica de RNAs em dados de censos de fauna de foraminíferos planctônicos (gráfico superior). O segundo gráfico apresenta uma estimativa da diferença entre as temperaturas médias de verão e inverno. No gráfico inferior estão plotadas as abundâncias relativas do Plexo menardiforme para comparação. 
Tabela 5.4. Desvios padrão máximo, mínimo e médio $\left({ }^{\circ} \mathrm{C}\right)$ das estimativas de paleotemperatura obtidas pela técnica de RNAs para o testemunho KF02.

\begin{tabular}{lccc}
\hline & TSM verão & TSM inverno & TSM média anual \\
\hline Desvio máximo & 1,09 & 1,78 & 0,81 \\
Desvio mínimo & 0,27 & 0,33 & 0,26 \\
Desvio médio & 0,54 & 0,91 & 0,49 \\
\hline
\end{tabular}

A comparação das estimativas de TSMs com a abundância relativa das espécies do Plexo menardiforme mostra claramente como as temperaturas estimadas aumentam em resposta ao aparecimento desta fauna associada a períodos mais quentes. No entanto, também foram estimadas paleotemperaturas elevadas para períodos em que a abundância de espécimes do Plexo menardiforme era mínima ou mesmo nula como em torno de 15 mil e 11,5 mil anos AP.

Quanto à diferença de temperatura entre as estimativas de TSM de verão e inverno, que poderia dar indícios da sazonalidade, não se observa um padrão definido. De acordo com o ciclo de precessão da órbita da Terra, o contraste sazonal máximo no Hemisfério sul estaria ocorrendo atualmente assim como teria ocorrido durante o UMG. Já o mínimo no contraste teria ocorrido em torno de 11 mil anos AP, quando o periélio ocorria durante o solstício de inverno do hemisfério Sul (Martin et al., 1997). No entanto, embora os dados pareçam sugerir uma tendência a um maior contraste sazonal entre aproximadamente 15 e 12 mil anos AP, não se observa uma tendência clara de sazonalidade que possa ser diretamente relacionada às mudanças na insolação associadas ao ciclo de precessão.

\subsubsection{Estimativas de paleossalinidade}

A Fig. 5.15 apresenta as estimativas de paleossalinidade obtidas para o testemunho KF02. Como descrito nos métodos (Capítulo 4), fez-se a distinção entre uma estimativa de variação geral e outra local, excluindo o efeito do volume de gelo global. Na curva de estimativas de salinidade "geral" se observa claramente o efeito da redução do volume de gelo global causando um decréscimo nos valores de SSM. 

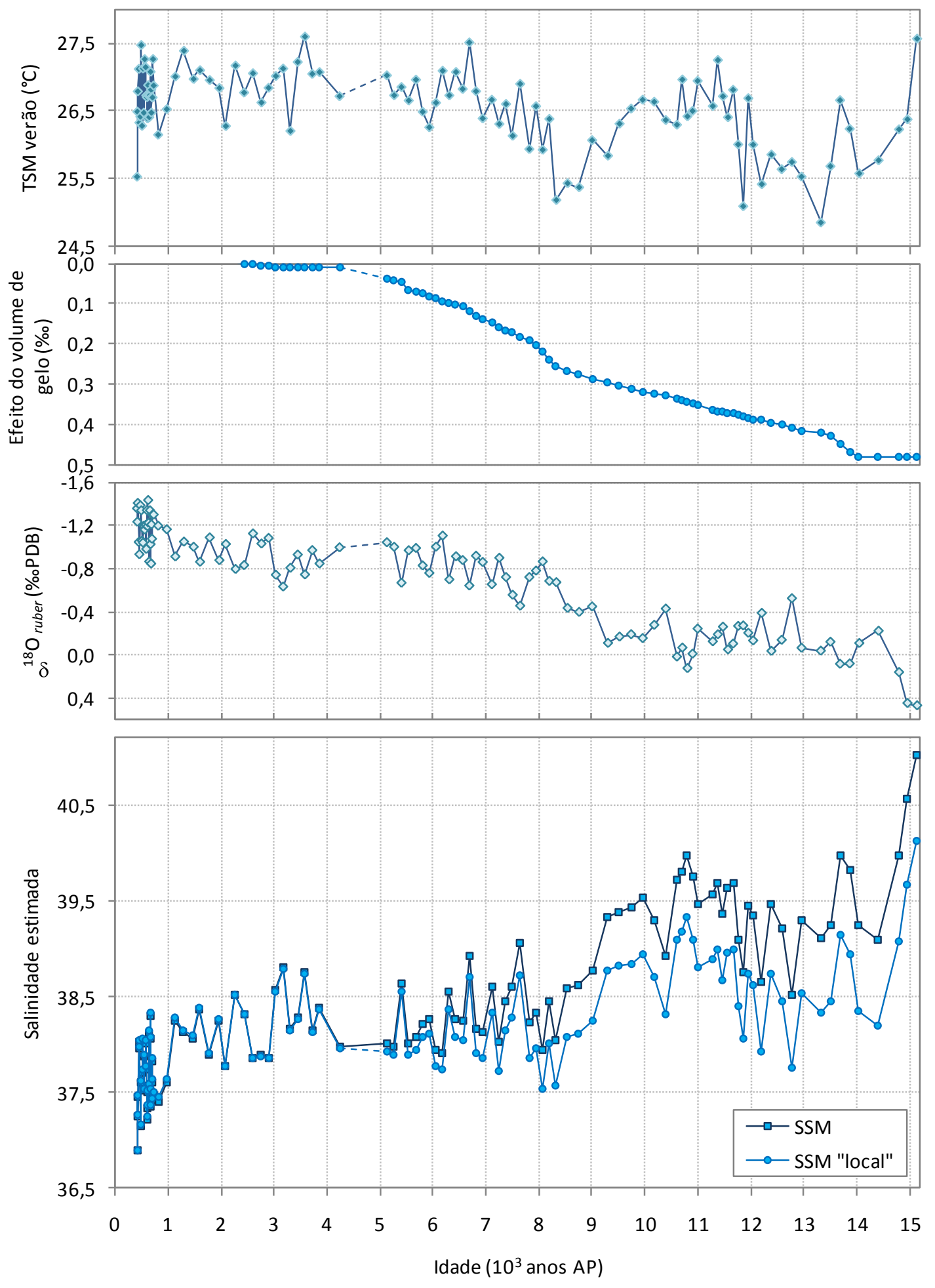

Fig. 5.15. Estimativas de paleo-SSMs obtidas para o testemunho KF02 a partir da aplicação do método residual. A SSM "local" se refere às estimativas de SSM após a exclusão do efeito do volume de gelo global. A Figura inclui os dados de variação da composição de isótopos de oxigênio em testas de G. ruber (white) e as estimativas de volume de gelo e de paleotemperatura de verão as quais foram utilizadas no cálculo das paleossalinidades. 
Na curva que desconsidera o efeito do volume de gelo global, também se verifica uma tendência a uma progressiva diminuição da SSM principalmente na base e no topo do testemunho e na transição Pleistoceno- Holoceno. Os maiores valores estimados de paleossalinidade teriam ocorrido em torno de 15, 13,8 e 10,8 mil anos AP.

\subsubsection{Estimativas de paleoprodutividade}

A Fig. 5.16 apresenta as variações ao longo do testemunho das variáveis relacionadas à produtividade. As abundâncias relativas de G. truncatulinoides (dex), $N$. dutertrei e de ostracodes e foraminíferos bentônicos sugerem uma maior produtividade durante a deglaciação e início do Holoceno, até aproximadamente 8 mil anos AP. Por outro lado, a curva de variação da razão G. bulloides/G. ruber não apresenta uma tendência clara, mas apesar disso os valores mais elevados ocorrem na deglaciação, dando suporte à idéia de uma maior produtividade durante este período. Finalmente, a curva de isótopos de carbono parece indicar o contrário dos demais indicadores, já que uma maior produtividade tende a ser acompanhada de um aumento na abundância relativa do isótopo pesado (pelo uso preferencial do isótopo leve na fotossíntese), no entanto, em média, os valores da seção mais antiga do testemunho são menores do que os valores ao longo do Holoceno. As possíveis causas para a discordância entre os diferentes indicadores são discutidos em detalhe no capítulo 6. 

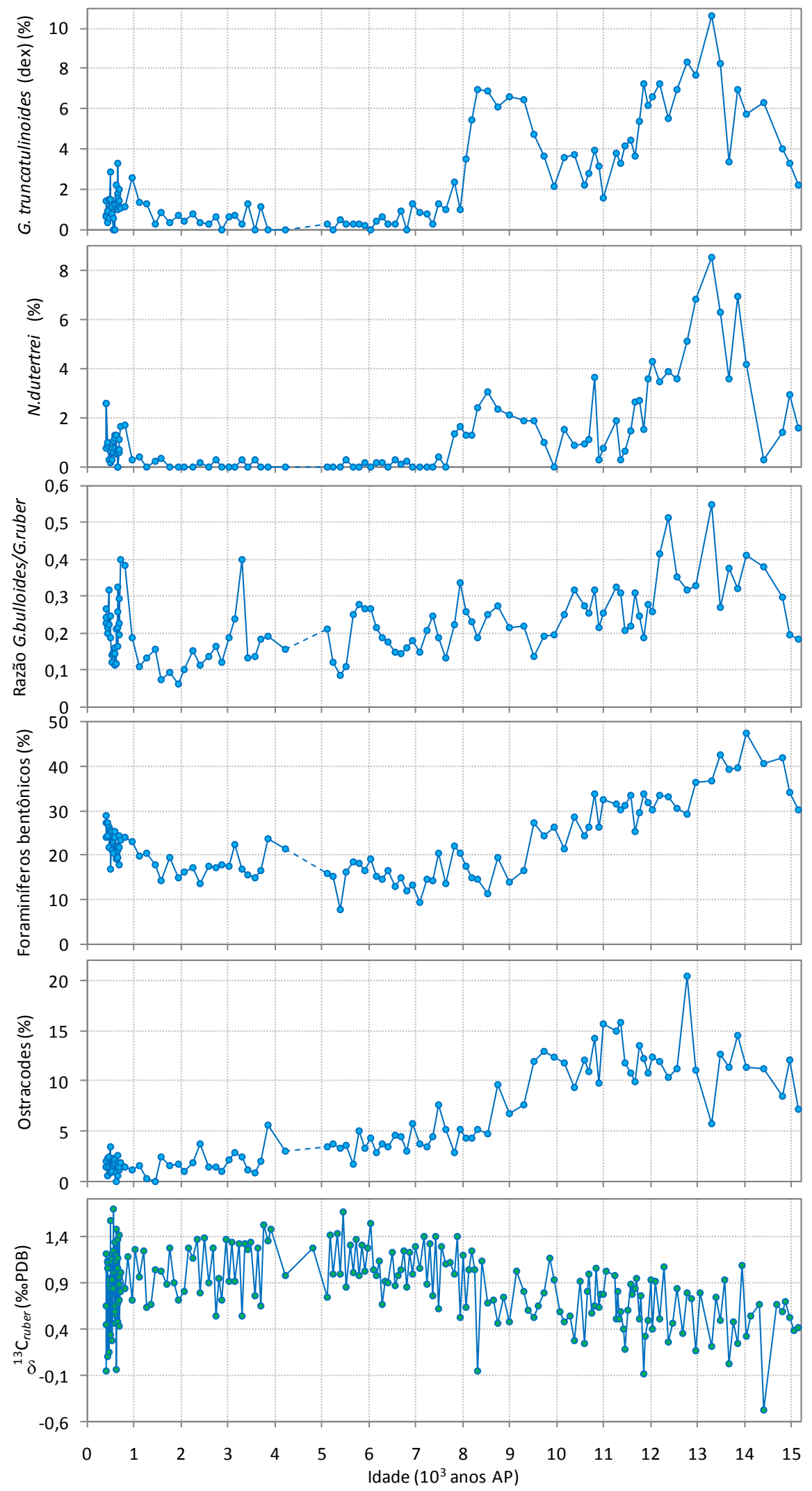

Fig.5.16. Variabilidade de parâmetros relacionados à paleoprodutividade incluindo dados de abundância relativa de $G$. truncatulinoides (dex) e $N$. dutertrei, razão $G$. bulloides $/ G$. ruber, percentagem de ostracodes e foraminíferos bentônicos e composição de isótopos de carbono em testas de G. ruber (white). 


\subsubsection{Análises de Teor de Carbonato e Fluorescência de Raios $X$}

A Fig. 5.17 apresenta os resultados das análises efetuadas na fração fina por Bariani (2009). O teor de carbonato apresenta um período de valores elevados na deglaciação, seguido de um período de valores mínimos do início do Holoceno até aproximadamente 3 mil anos AP e finalmente um novo aumento até o topo do testemunho. Já os dados de FRX, os quais foram resumidos nas razões Ti/Ca e Fe/Ca, mostram claramente uma rápida diminuição da influência continental ao longo do tempo, desde a base do testemunho (em torno de 15 mil anos AP) até aproximadamente 9 mil anos AP, seguida de um novo aumento ao longo do Holoceno até o topo do testemunho. O coeficiente de correlação entre as curvas de variação das razões Ti/Ca e $\mathrm{Fe} / \mathrm{Ca}$ é igual a 0,886 .

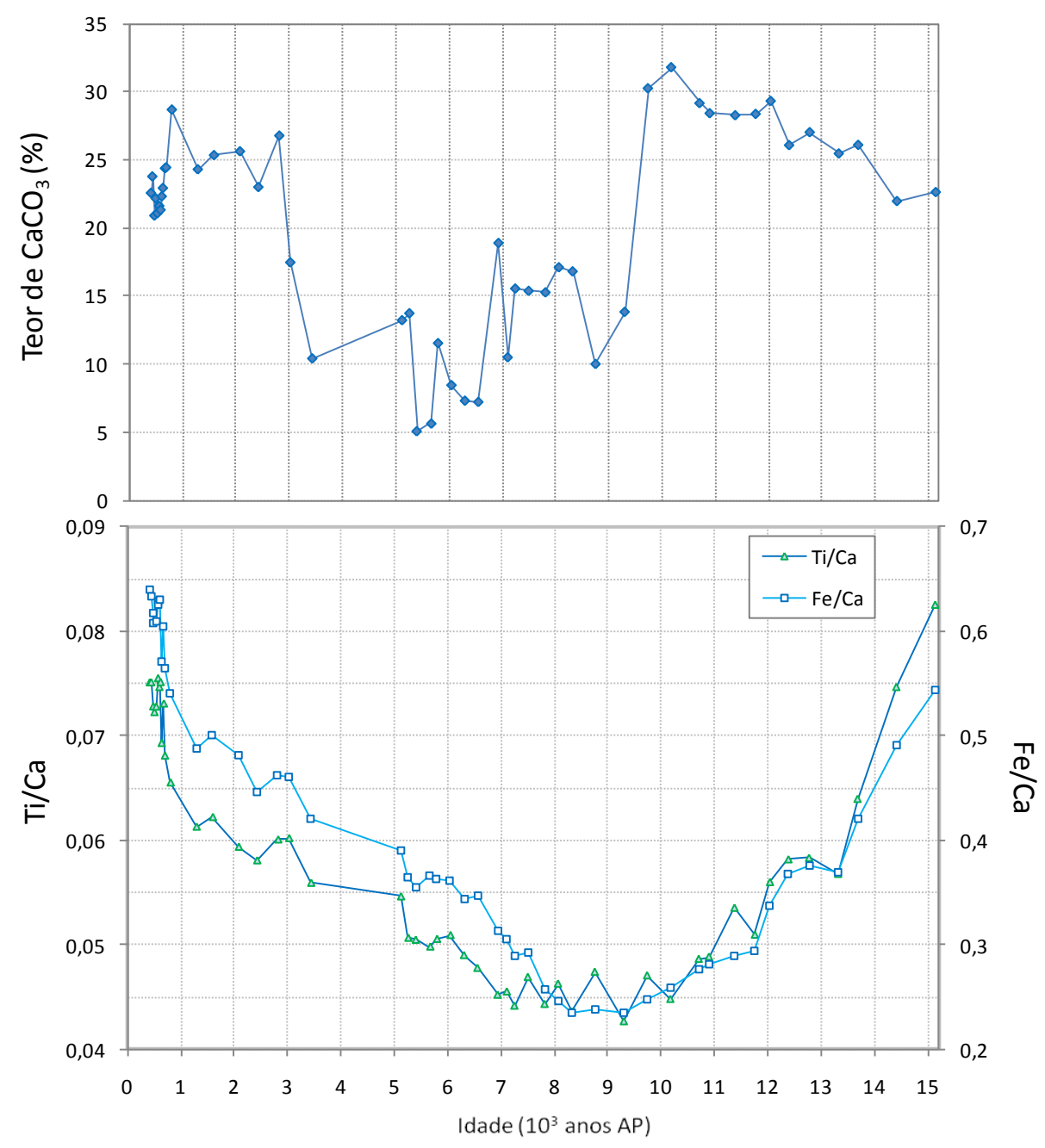

Fig. 5.17. Estimativas da variação do teor de $\mathrm{CaCO}_{3}$ (gráfico superior) e das razões Ti/Ca e $\mathrm{Fe} / \mathrm{Ca}$ (gráfico inferior) na fração fina dos sedimentos ao longo do testemunho KF02 de acordo com dados de Bariani (2009). 
Embora a resolução temporal dos dados de FRX seja menor que as demais estimativas obtidas para este testemunho seja por análises de fauna ou análises isotópicas, os resultados de FRX evidenciam dois aspectos importantes: (1) as mudanças no grau de influência continental foram aparentemente graduais, ou seja, não há registro de eventos bruscos que possam comprometer a confiabilidade na qualidade do testemunho e (2) a diminuição relativamente acelerada das razões Ti/Ca e Fe/Ca da base do testemunho até o início do Holoceno está de acordo com o previsto em função das variações do nível do mar e conseqüente recuo da linha de costa, no entanto, o novo aumento das razões ao longo do Holoceno até valores semelhantes aos da base não pode ser atribuído a variações do nível do mar.

Por outro lado, a comparação dos dois gráficos da Fig. 5.17 mostra que os valores máximos de teor de $\mathrm{CaCO}_{3}$ e das razões Ti/Ca e Fe/Ca coincidem nos extremos do testemunho. Isto significa que as maiores razões $\mathrm{Ti} / \mathrm{Ca}$ e $\mathrm{Fe} / \mathrm{Ca}$ ocorreram apesar das maiores concentrações de $\mathrm{CaCO}_{3}$ nos mesmos períodos o que significa que o aporte de sedimentos terrígenos deve ter sido muito intenso nesses períodos. As implicações destes resultados são discutidas no capítulo 6.

\subsection{REANÁLISE DO TESTEMUNHO SAN76}

\subsubsection{Modelo de idade}

A Tabela 5.5 e a Fig. 5.18 apresentam as diferenças entre os modelos de idade atual e o utilizado para este testemunho em trabalhos anteriores. Em linhas gerais, as diferenças entre os dois modelos são pequenas entre 2 e 18 mil anos AP. As diferenças mais significativas são na idade estimada da amostra mais próxima ao topo $(3 \mathrm{~cm}$ de profundidade) e na seção mais antiga do que 18 mil anos AP.

A Fig. 5.19 apresenta a correlação entre as curvas de isótopos de oxigênio em espécimes de foraminíferos bentônicos do gênero Cibicidoides e a curva do SPECMAP (Martinson et al., 1987) junto com os pontos de controle das quatro datações de radiocarbono. De acordo com o modelo gerado, foram calculadas as taxas de sedimentação ao longo do testemunho (Fig. 5. 20). De acordo com este novo modelo de idade, a taxa média de sedimentação foi de $14 \mathrm{~cm} / 10^{3}$ anos e os valores mínimo e 
máximo foram 7 e $32 \mathrm{~cm} / 10^{3}$ anos, respectivamente. Já para a seção do testemunho que coincide em idade com o testemunho KF02 a taxa média de sedimentação foi de 11 $\mathrm{cm} / 10^{3}$ anos e os valores mínimo e máximo corresponderam respectivamente a 7 e 13 $\mathrm{cm} / 10^{3}$ anos.

Tabela 5.5. Datações de radiocarbono e respectivas estimativas de idades calendário para o testemunho SAN76.

\begin{tabular}{ccccccc}
\hline $\begin{array}{c}\text { Prof. } \\
\text { amostra } \\
(\mathrm{cm})\end{array}$ & $\begin{array}{c}\text { Espécie } \\
\text { analisada }\end{array}$ & $\begin{array}{c}\text { Idade }{ }^{14} \mathrm{C} \\
\left(10^{3} \text { anos }\right)\end{array}$ & $\begin{array}{c}\text { Erro } \\
(\text { Idade } \\
\left.{ }^{14} \mathrm{C}\right)\end{array}$ & $\begin{array}{c}\text { Idade }{ }^{14} \mathrm{C} \\
\text { corrigida pelo } \\
\text { efeito de } \\
\text { reservatório } \\
\left(10^{3} \text { anos }\right)\end{array}$ & $\begin{array}{c}\text { Idade } \\
\text { calendário } \\
\left(\mathbf{1 0}^{3} \text { anos }\right. \\
\mathbf{A . P .})^{\mathbf{a}}\end{array}$ & $\begin{array}{c}\text { Erro } \\
\text { (Idade } \\
\text { calendário) }\end{array}$ \\
\hline 13 & G. ruber & 3010 & 30 & 2747 & $\mathbf{2 8 3 1}$ & 35 \\
148 & G. ruber & 13450 & 70 & 13187 & $\mathbf{1 5 3 5 7}$ & 130 \\
320 & G. ruber & 19300 & 230 & 19037 & $\mathbf{2 2 6 3 4}$ & 265 \\
416 & G. ruber & 29400 & 160 & 29137 & $\mathbf{3 4 5 5 3}$ & 215 \\
\hline
\end{tabular}

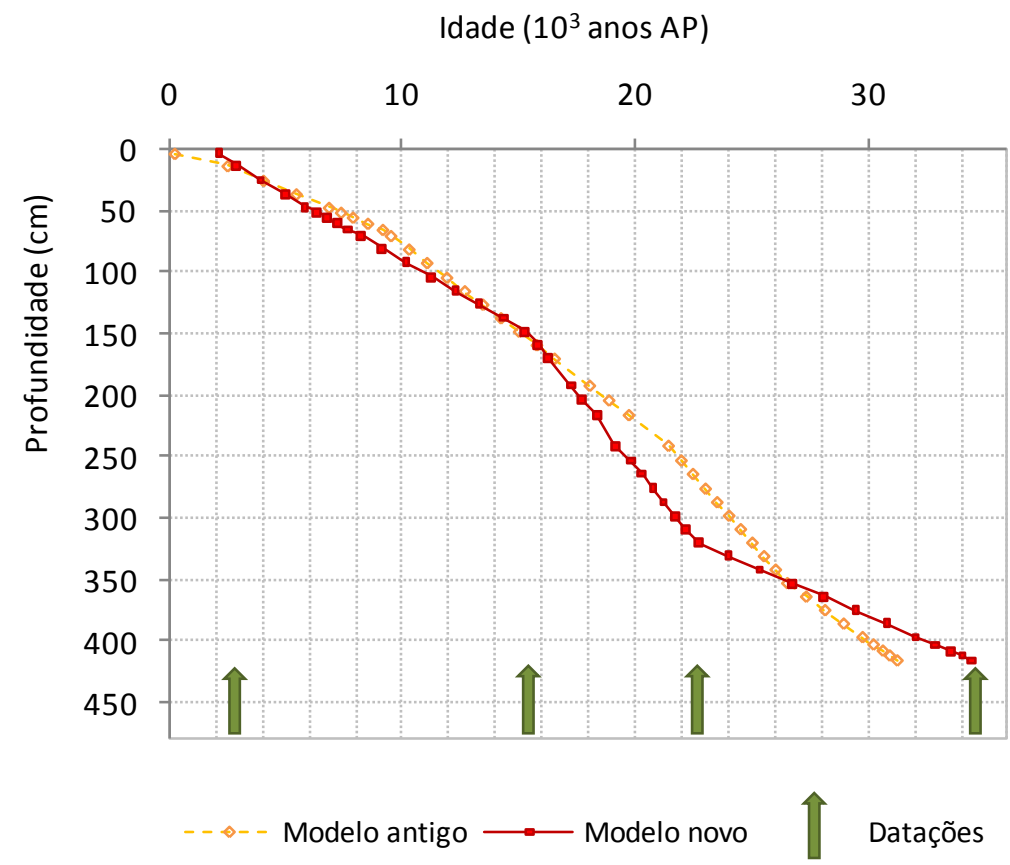

Fig. 5.18. Relação profundidade-idade dos modelos novo e antigo para o testemunho SAN76. 


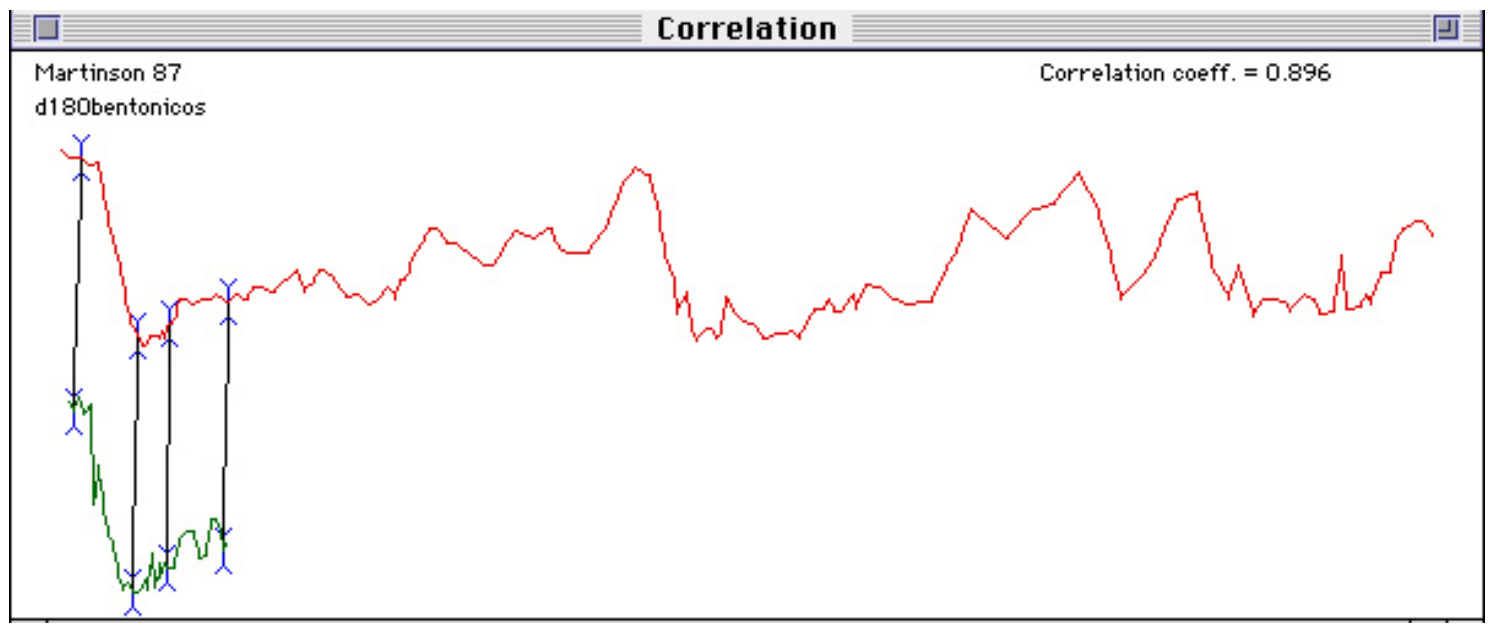

Fig. 5.19. Correlação entre a curva do SPECMAP (Martinson et al., 1987) e a curva de isótopos de oxigênio em foraminíferos bentônicos do gênero Cibicidoides feita com o programa AnalySeries (Paillard et al., 1996).

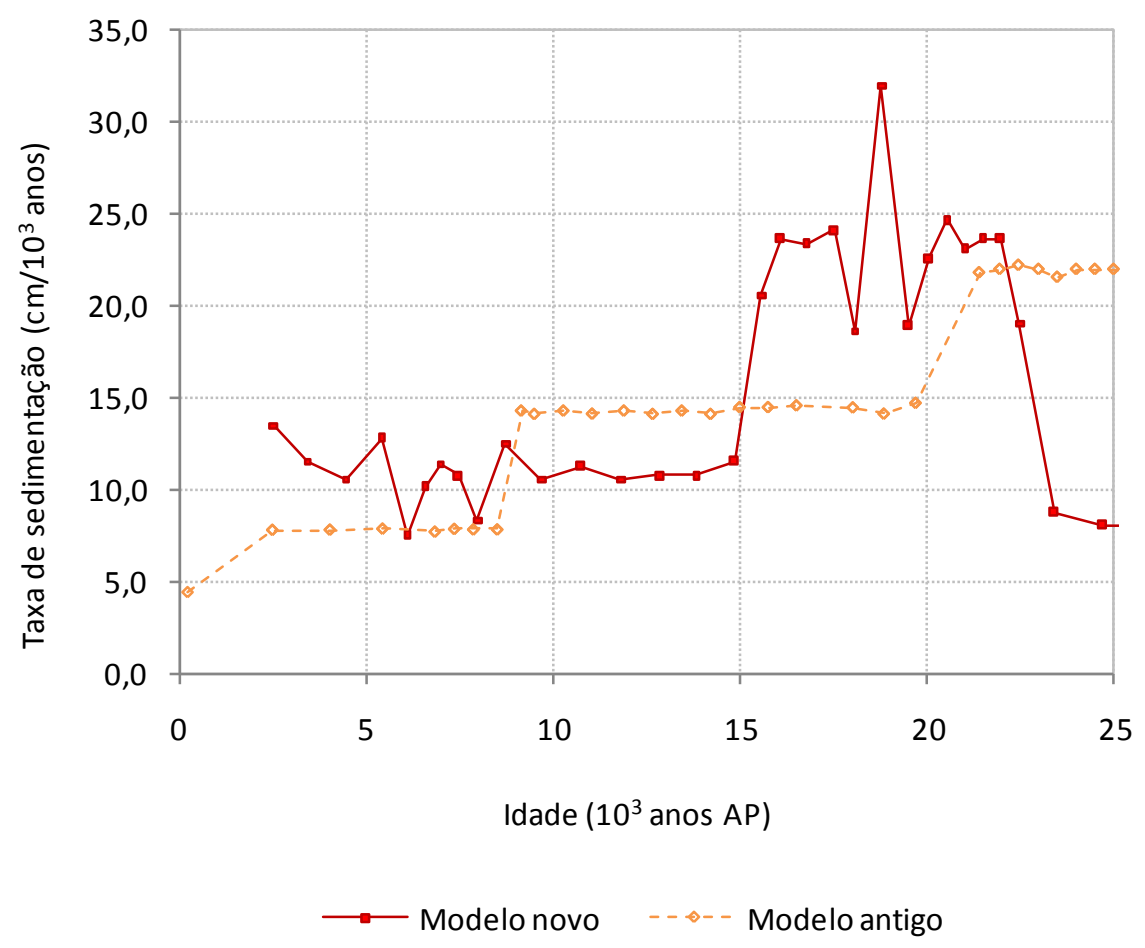

Fig. 5.20. Estimativas de taxas de sedimentação ao longo do testemunho SAN76 de acordo com os modelos de idade novo e antigo. 


\subsubsection{Estimativas de paleotemperatura}

A Fig. 5.21 apresenta uma comparação das estimativas de paleotemperatura obtidas pelas técnicas de SIMMAX (Toledo, 2000) e RNAs (este trabalho) para o testemunho SAN76 para o verão e inverno. Para facilitar a comparação dos resultados proporcionados pelos diferentes métodos os resultados foram plotados usando o mesmo modelo de idade (aquele recalculado nesta tese). Observa-se que para algumas amostras, os dois métodos proporcionaram estimativas significativamente diferentes. No entanto, em média, os valores foram semelhantes (Tabela 5.6). Os desvios das estimativas obtidas através das RNAs são apresentados na Tabela 5.7.
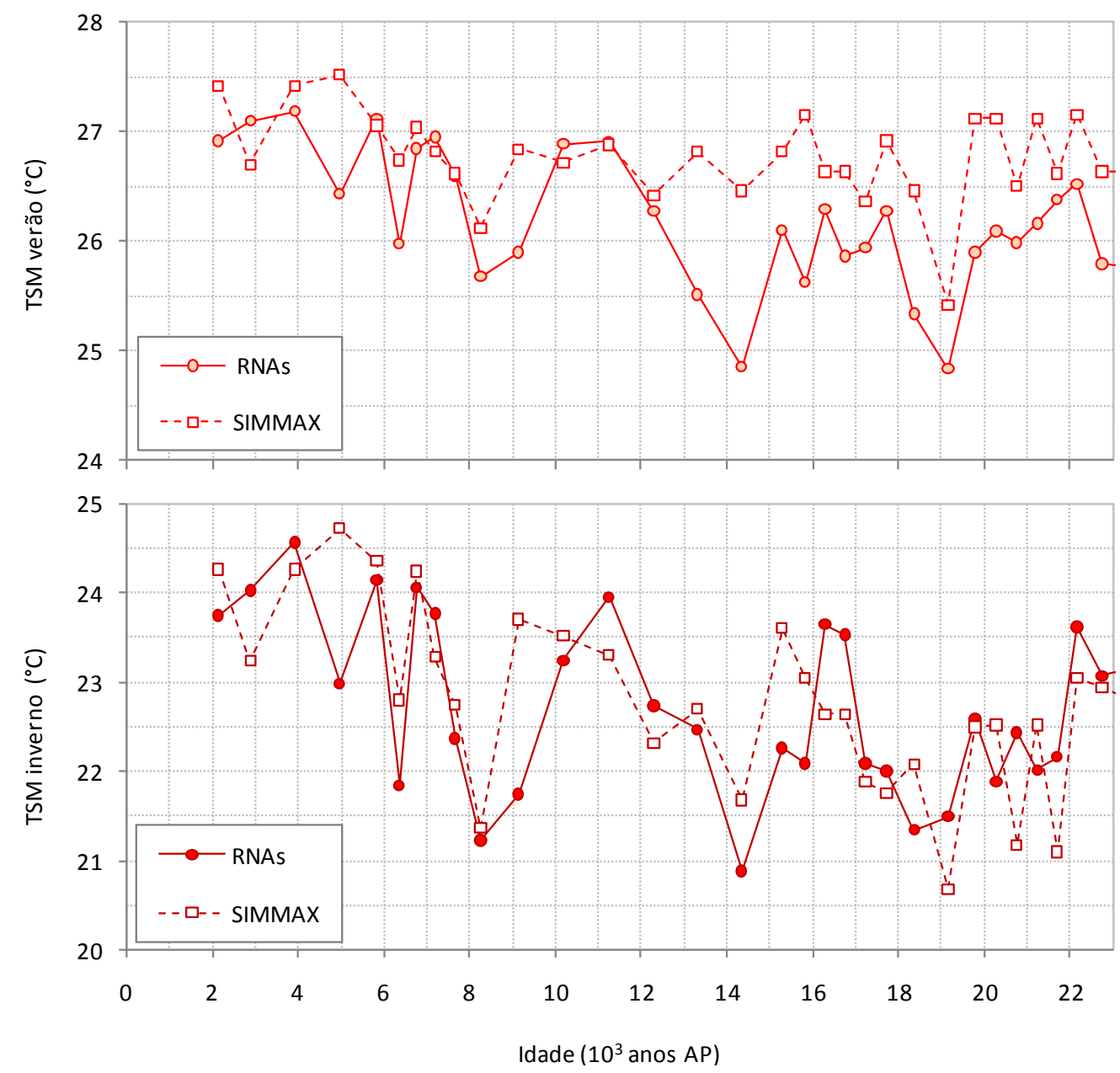

Fig. 5.21. Comparação das estimativas de paleotemperatura superficial do mar de verão (gráfico superior) e inverno (gráfico inferior) obtidas pelos métodos SIMMAX (linha pontilhada) e RNAs (linha contínua). 
Tabela 5.6. Comparação dos valores máximos, mínimos e médios de paleotemperaturas $\left({ }^{\circ} \mathrm{C}\right)$ estimadas pelos métodos de RNAs e SIMMAX.

\begin{tabular}{lcccc}
\hline & Verão RNAs & Inverno RNAs & Verão SIMMAX & Inverno SIMMAX \\
\hline Máximo: & 27,2 & 24,6 & 27,5 & 24,7 \\
Mínimo: & 24,8 & 20,4 & 25,0 & 19,6 \\
Médio: & 26,1 & 22,4 & 26,7 & 22,5 \\
\hline
\end{tabular}

Tabela 5.7. Desvios padrão máximo, mínimo e médio $\left({ }^{\circ} \mathrm{C}\right)$ das estimativas de paleotemperatura obtidas pela técnica de RNAs para o testemunho SAN76.

\begin{tabular}{lccc}
\hline & TSM verão & TSM inverno & TSM média anual \\
\hline Desvio máximo & 0,65 & 1,86 & 0,74 \\
Desvio mínimo & 0,24 & 0,30 & 0,28 \\
Desvio médio & 0,45 & 1,06 & 0,49 \\
\hline
\end{tabular}

Em comum, os métodos sugerem um mínimo de temperaturas em torno de 19 mil anos AP e uma tendência ao aquecimento ao longo do Holoceno. Outro evento frio em torno de 14 mil anos AP tinha sido sugerido pelo SIMMAX apenas para o inverno. Já para esse mesmo período, as estimativas das RNAs sugerem um resfriamento tanto no verão quanto no inverno. Os métodos também concordam em uma tendência ao aquecimento no início do Holoceno, seguida de um resfriamento importante em torno de 8 mil anos AP.

\subsubsection{Estimativas de paleossalinidade}

Da mesma forma que para as paleotemperaturas, a Fig. 5.22 apresenta as estimativas de paloessalinidade para o testemunho SAN76 obtidas a partir de estimativas de paleotemperatura com os métodos SIMMAX (Toledo et al., 2007b) e RNAs (esta tese). Observa-se que, apesar da discrepância nas estimativas de paleotemperaturas para algumas amostras dependendo do método utilizado, as estimativas de paleossalinidade são muito semelhantes o que significa que as razões isotópicas em $G$. ruber pesam mais do que as estimativas de paleotemperatura no cálculo das paleossalinidades. 

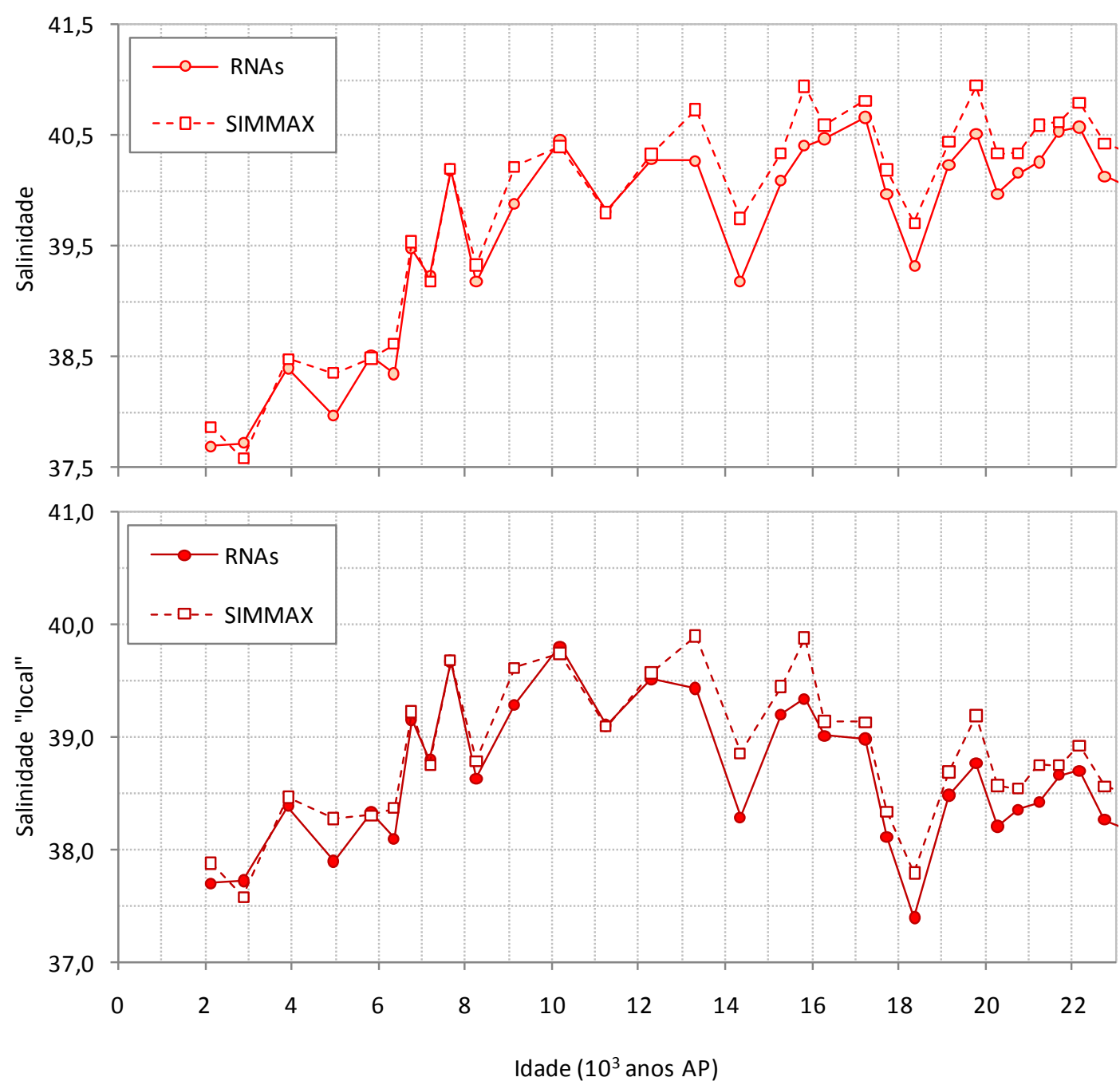

Fig. 5.22. Comparação das estimativas de paleossalinidade superficial do mar "total" (gráfico superior) e "local", excluindo o efeito do volume de gelo (gráfico inferior) obtidas pelos métodos SIMMAX (linha pontilhada) e RNAs (linha contínua).

\subsection{RESULTADOS COMBINADOS DE KF02 E SAN76}

Embora os resultados e a discussão sejam apresentados em capítulos separados, antes de iniciar a apresentação dos resultados conjuntos dos dois testemunhos analisados, considerou-se necessária a menção de algumas questões importantes, as quais são abordadas em detalhe no capítulo 6. Em primeiro lugar, o fato de ambos os testemunhos terem sido coletados na Bacia de Santos, não significa que tenham registrado exatamente as mesmas condições oceanográficas. Segundo, devido às maiores taxas de sedimentação, a resolução temporal do testemunho KF02 é muito 
maior do que a do testemunho SAN76. Terceiro, além da resolução temporal do testemunho KF02 ser melhor, o espaçamento entre amostras foi muito menor do que no testemunho SAN76.

Nas Figuras 5.23 a 5.25 são apresentadas as comparações das abundâncias relativas das espécies mais relevantes ao longo dos dois testemunhos. Não se observa uma concordância clara entre testemunhos. Inclusive, de acordo com os modelos de idade utilizados, o reaparecimento de G. menardii não teria ocorrido simultaneamente nas duas áreas. $\mathrm{O}$ reaparecimento em abundâncias significativas (acima de 1\%) teria ocorrido em torno de 8 mil anos no testemunho KF02 e 6 mil anos no testemunho SAN76. No testemunho KF02, além do reaparecimento de G. menardii ter acontecido antes, as abundâncias tanto de G. menardii quanto de G. tumida, alcançaram valores maiores (Fig. 5.24). A abundância relativa de outra espécie que indica o retorno de águas mais quentes, G. calida, também parece ter ocorrido antes na área do testemunho KF02 (Fig. 5.23).

Assim como no testemunho KF02, a espécie mais abundante no testemunho SAN76 foi G. ruber (Fig. 5.25). Neste caso, a falta de concordância entre testemunhos pode ser apenas conseqüência da menor resolução e maior espaçamento de amostragem no testemunho SAN76, uma vez que não se observa uma tendência temporal clara como no Plexo menardiforme ou G. calida.

A Fig. 5.26 apresenta as variações na composição de isótopos de oxigênio em $G$. ruber (white). De maneira geral, observa-se a mesma tendência de diminuição dos valores isotópicos em direção ao topo. No entanto, na seção compreendida entre 6 e 14 mil anos AP, os valores isotópicos no testemunho KF02 são menores do que no SAN76 o que pode ser o resultado de TSMs maiores e/ou SSMs menores. Essa defasagem nos valores isotópicos está de acordo com as diferenças na fauna, especialmente no reaparecimento tardio do Plexo menardiforme no testemunho SAN76 em comparação com o testemunho KF02. 


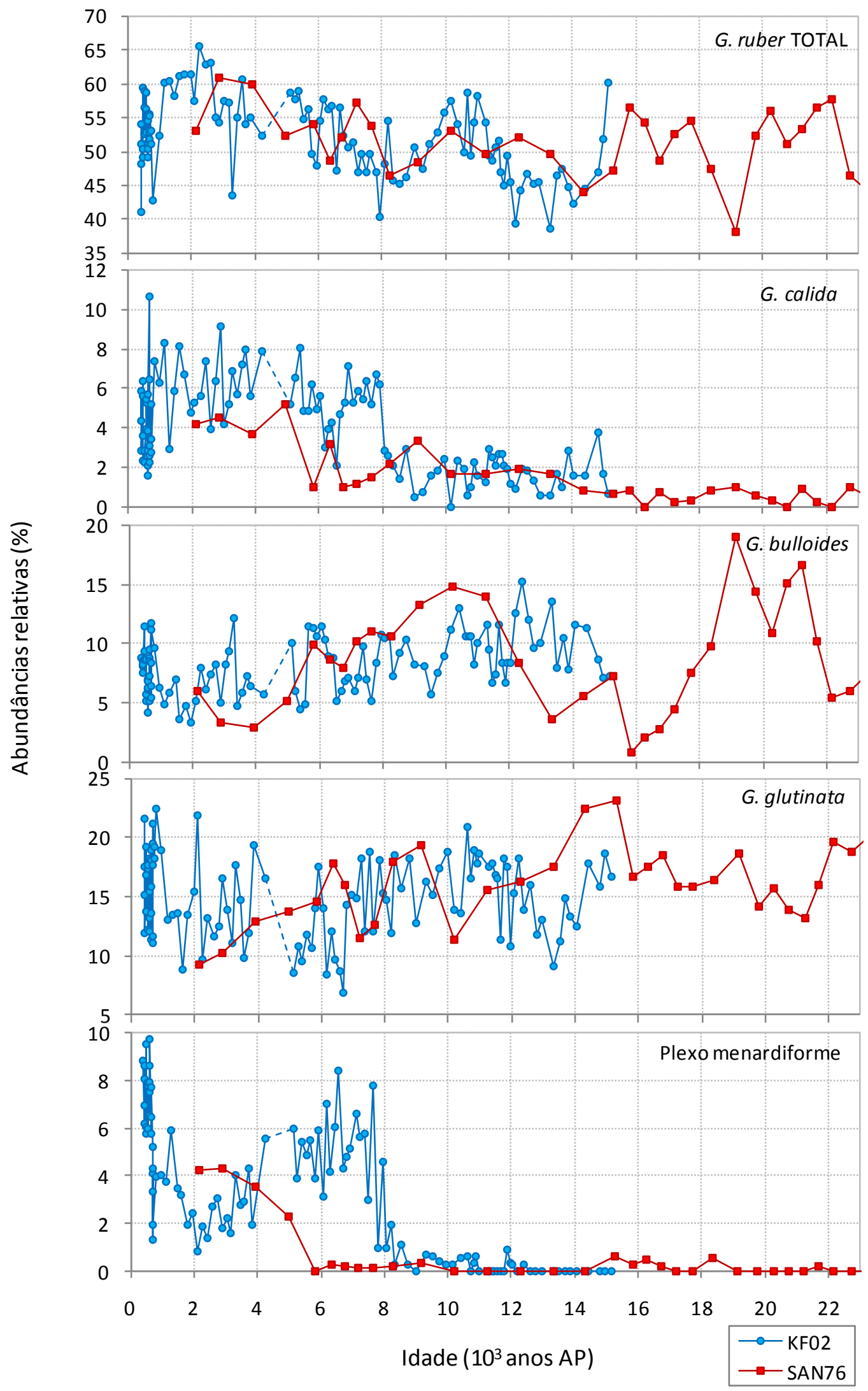

Fig. 5.23. Comparação das variações na abundância relativa das espécies mais representativas ao longo dos testemunhos KF02 e SAN76. 

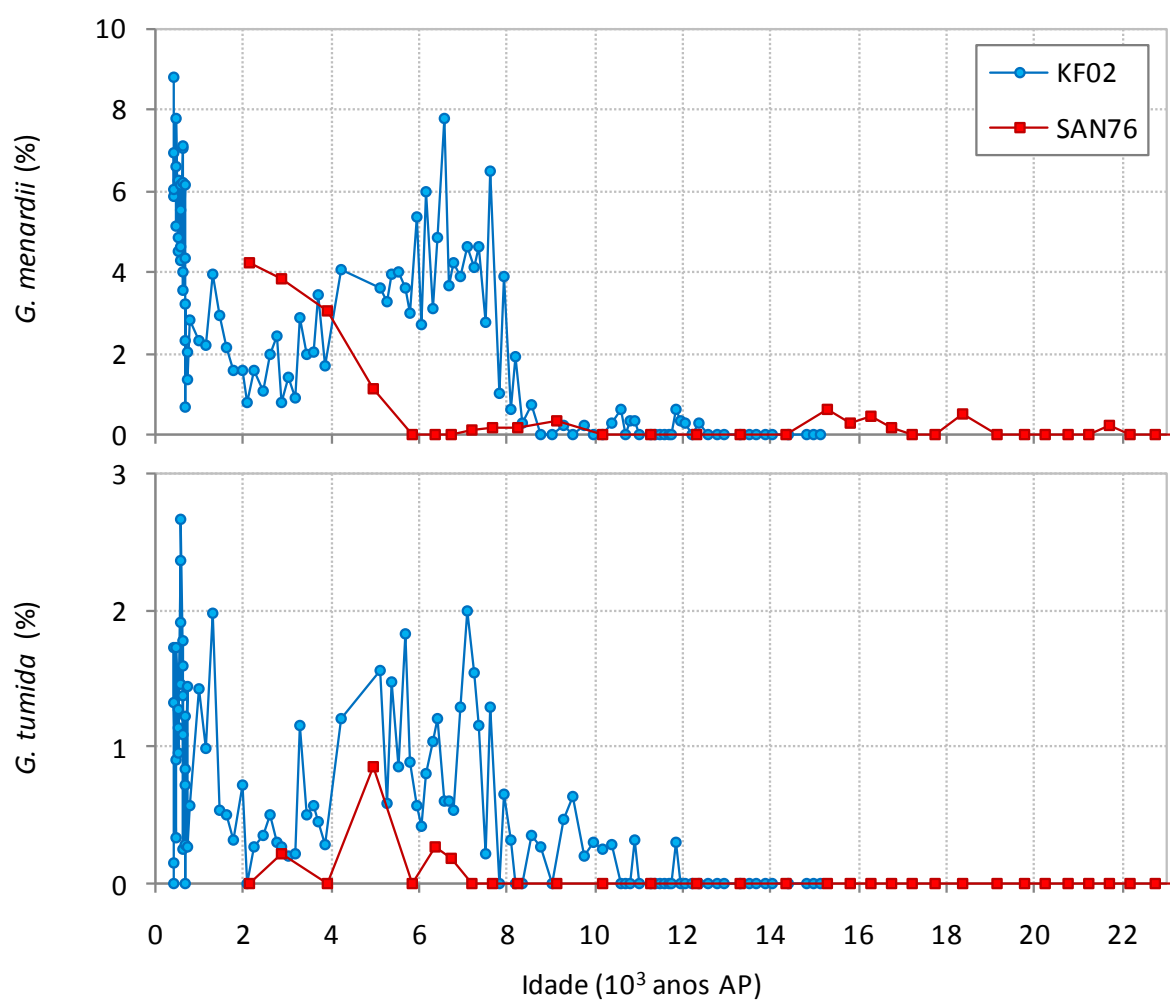

Fig. 5.24. Comparação das variações na abundância relativa de G. menardii e G. tumida ao longo dos testemunhos KF02 e SAN76.

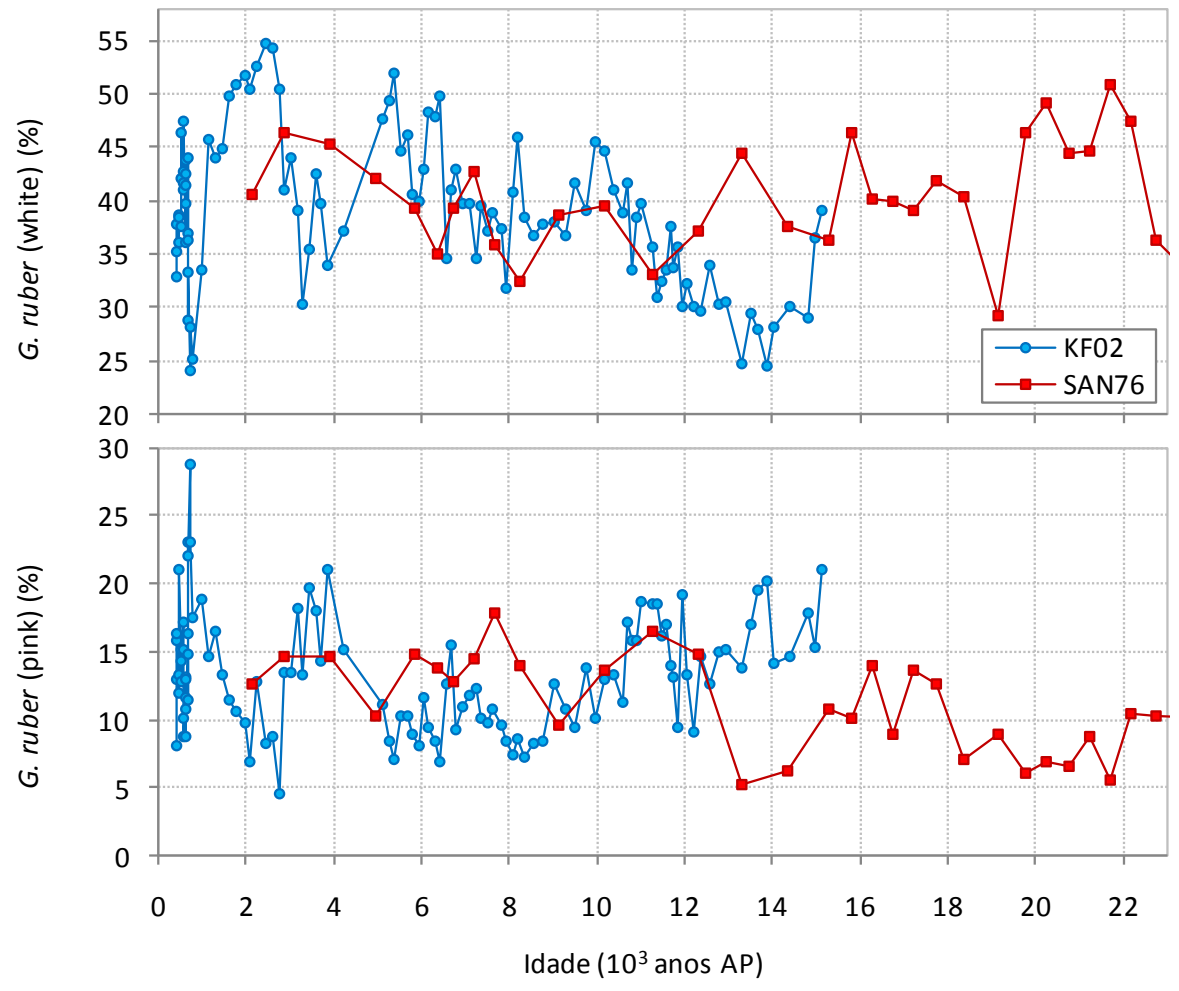

Fig. 5.25. Comparação das variações na abundância relativa dos dois morfotipos de G. ruber ao longo dos testemunhos KF02 e SAN76. 


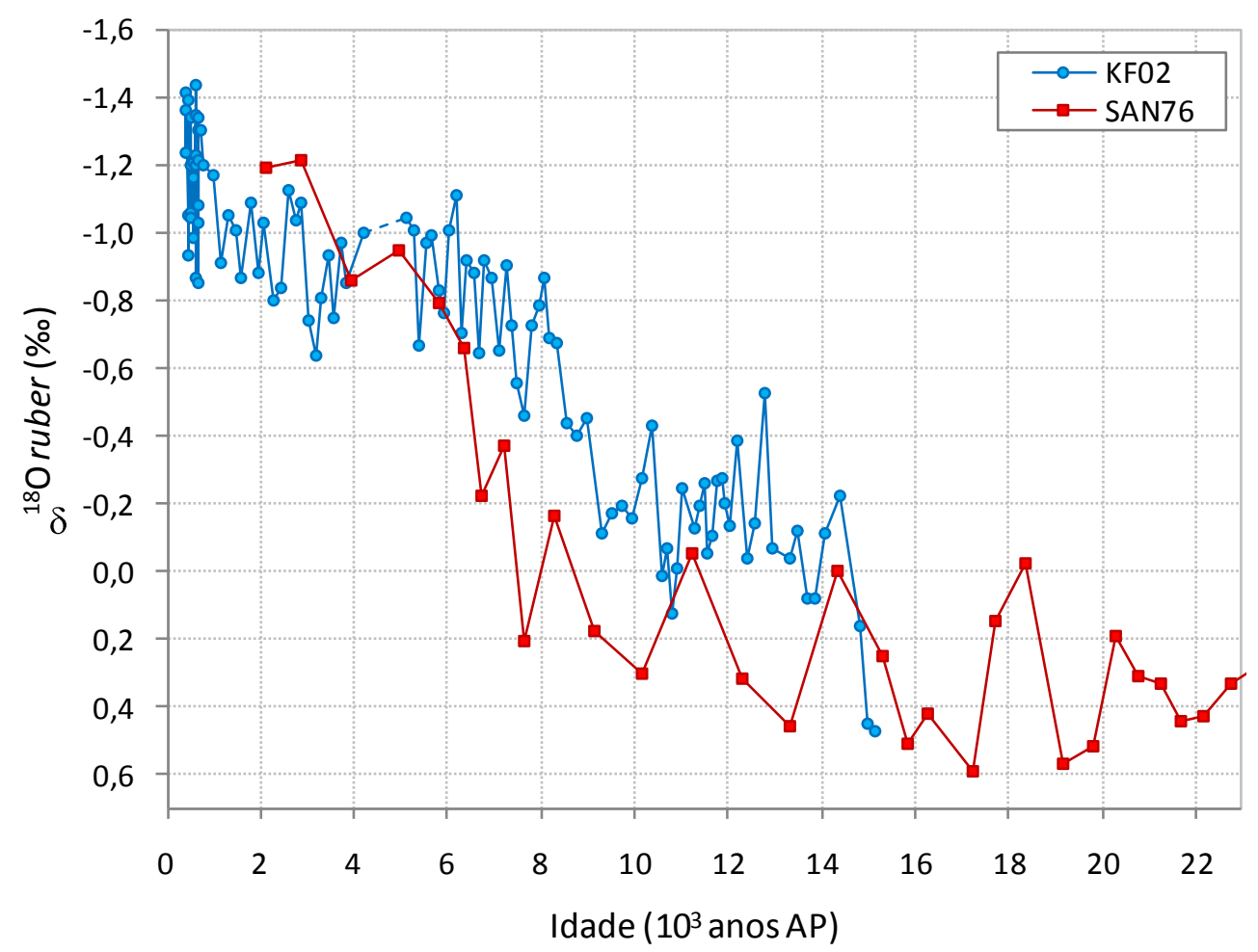

Fig. 5.26. Variações na composição de isótopos de oxigênio em testas de G. ruber (white) nos testemunhos KF02 e SAN76.

Nas Figs. 5.27 a 5.28 são apresentados os resultados das estimativas de paleotemperatura. Observa-se que a amplitude das TSMs estimadas para o inverno é muito maior que para o verão (Fig. 5.27). A comparação entre as estimativas dos dois testemunhos mostra uma boa concordância, principalmente levando em consideração o maior espaçamento das amostras analisadas no testemunho SAN76 e o fato do modelo de idade ser menos preciso por se basear em menos datações de radiocarbono. As estimativas de ambos os testemunhos concordam em dois períodos de resfriamento intenso em torno de 14 e 8 mil anos AP. Entre estes dois períodos teria ocorrido um aquecimento significativo, atingindo valores máximos entre 12 e 11 mil anos AP. Outro período frio é sugerido pelo registro do testemunho SAN76 em torno de 19 mil anos AP. 


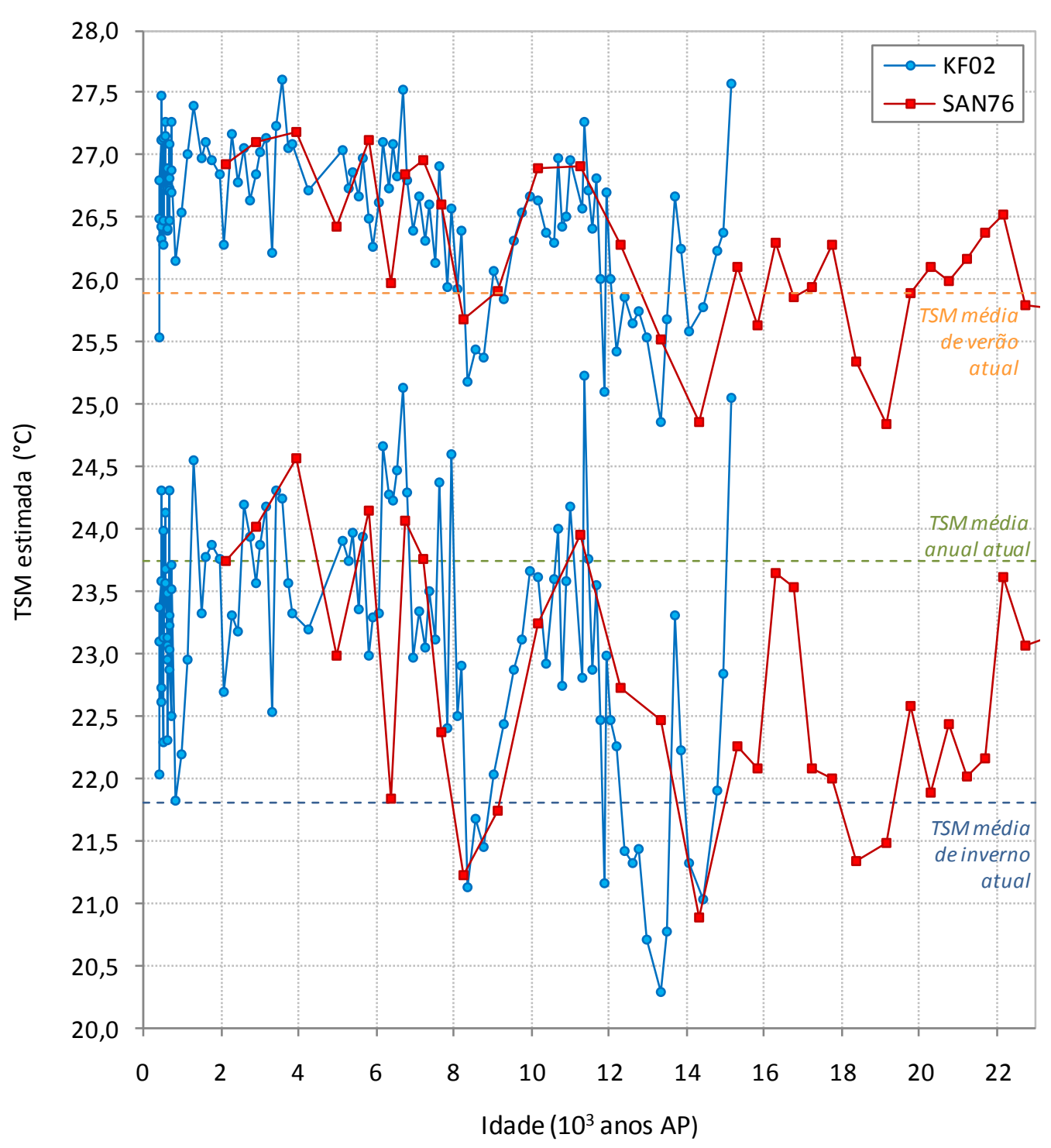

Fig. 5.27. Comparação das variações das estimativas de paleotemperaturas de verão (gráfico superior) e inverno (gráfico inferior) a partir da técnica das RNAs nos testemunhos KF02 e SAN76. As linhas indicativas das TSMs médias de verão, inverno e média anual se referem a dados atuais segundo o WOA05 (Locarnini et al., 2006).

Na Fig. 5.27 também foram plotadas linhas indicativas dos valores atuais de TSMs médias anuais e de verão (janeiro a março) e inverno (julho a setembro). Observa-se que, desconsiderando a amostra mais próxima ao topo no testemunho KF02, as estimativas de TSM de verão foram maiores do que a média atual exceto em três momentos em torno de 8, 14 e 19 mil anos AP, respectivamente. Esses três mesmos períodos foram os que apresentaram estimativas de TSMs de inverno também abaixo da média atual. Da mesma forma, no gráfico superior da Fig. 5.28, a linha indicativa da 
TSM média anual mostra que as estimativas foram de temperaturas maiores para todo o período analisado exceto para os três casos já mencionados, em torno de 8, 14 e 19 mil anos AP, com poucas exceções no Holoceno de valores próximos à média atual.

A comparação das diferenças de temperatura entre as estimativas de TSMs de verão e inverno (Fig. 5.28), não mostra uma concordância clara entre testemunhos.
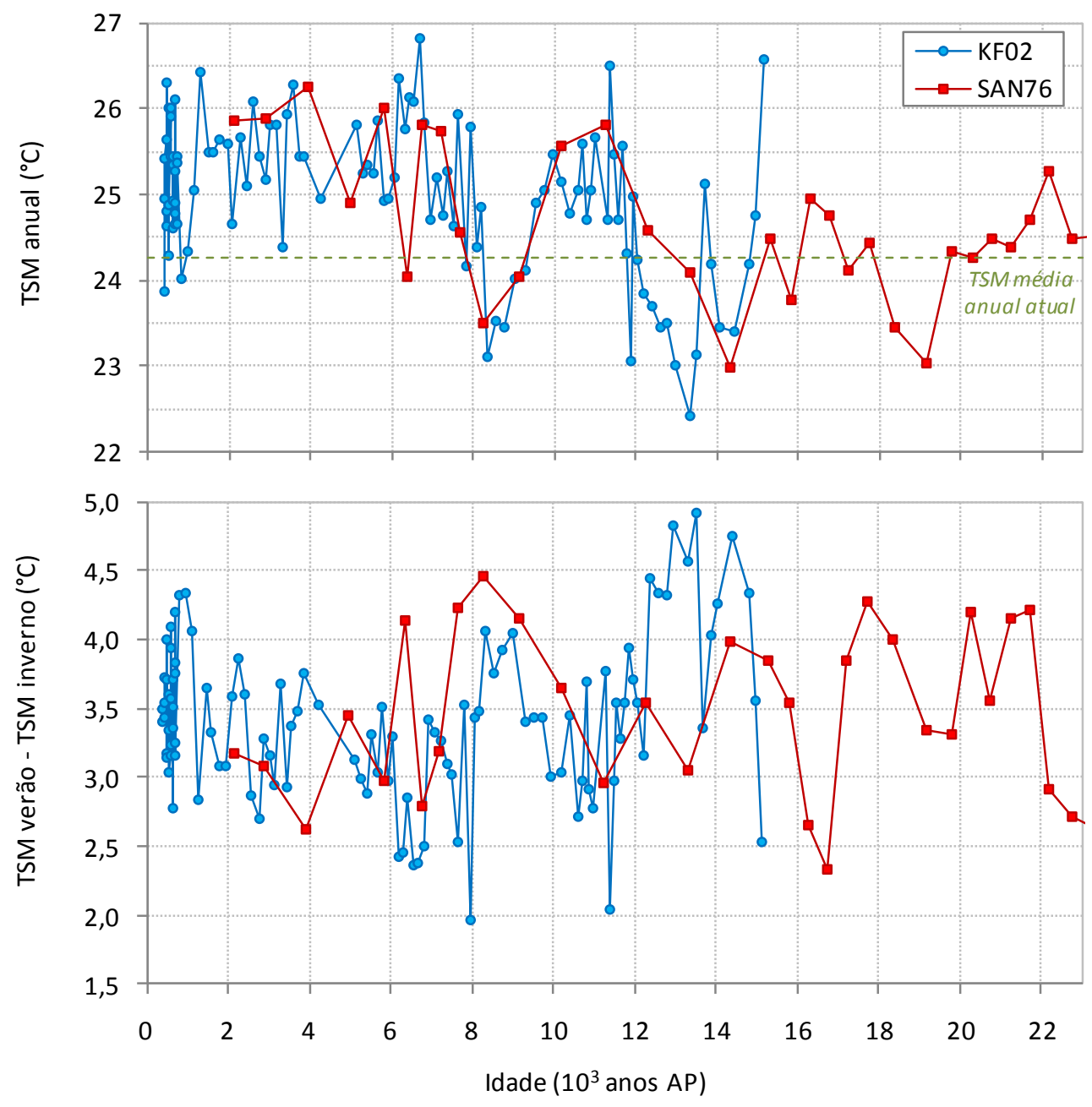

Fig. 5.28. Comparação das variações das estimativas de paleotemperatura média anual e da diferença de temperatura de verão menos inverno nos testemunhos KF02 e SAN76.

A comparação das estimativas de paleossalinidade é apresentada na Fig. 5.29. As curvas de paleossalinidade "total" se assemelham mais do que as de paleossalinidade "local", já que as primeiras incluem o mesmo sinal global do efeito do volume de gelo. As estimativas apontam para maiores valores de salinidade durante a deglaciação e um 
progressivo decréscimo ao longo do Holoceno, no entanto, os máximos não coincidem e o início da diminuição dos valores de salinidade parece ter ocorrido antes no testemunho KF02 do que no testemunho SAN76.
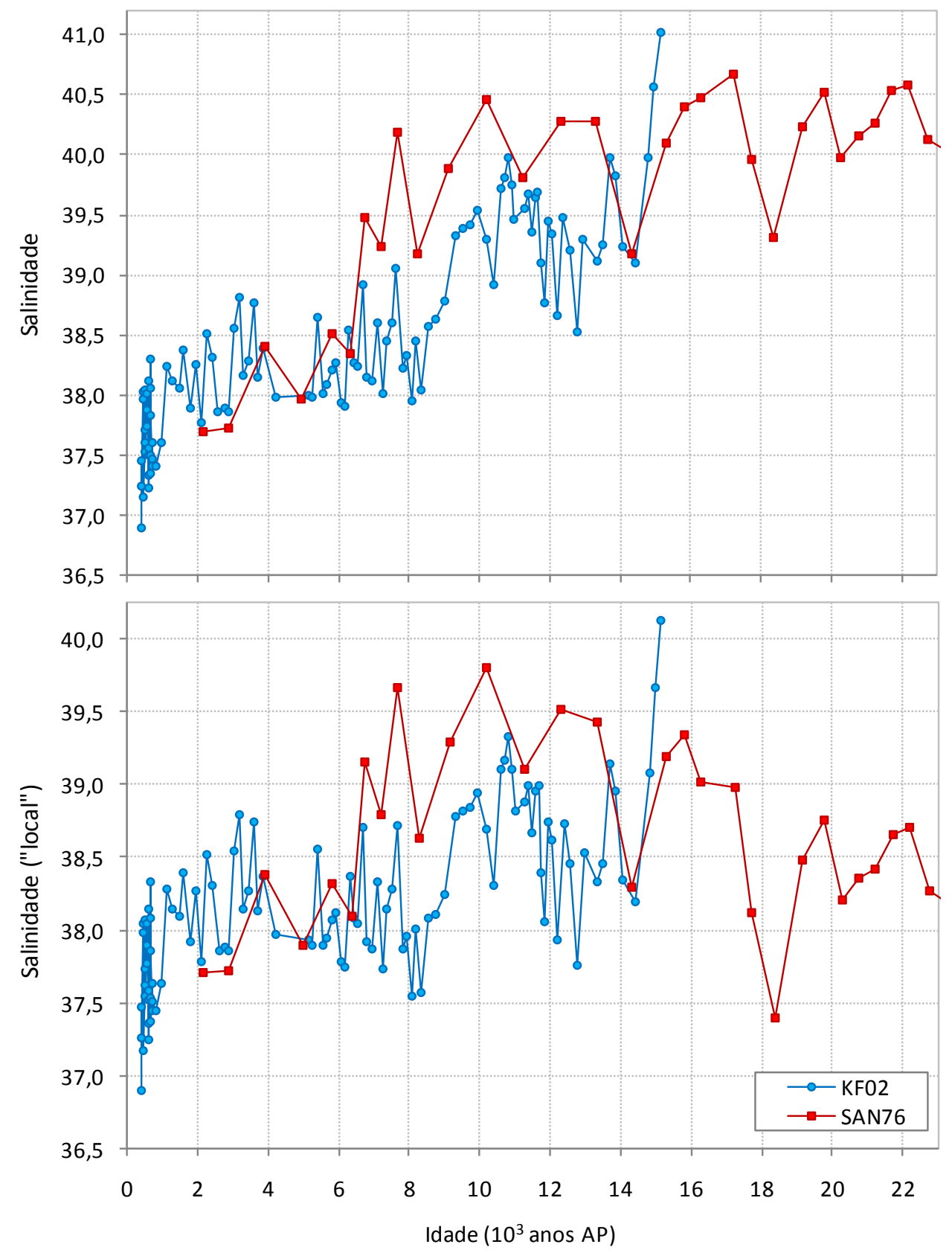

Fig. 5.29. Comparação das variações nas estimativas de paleossalinidade nos testemunhos KF02 e SAN76. 
Na Fig. 5.30 são apresentadas as variações nos parâmetros relacionados com a paleoprodutividade. Dois aspectos chamam a atenção: (1) a falta de concordância entre testemunhos e (2) a falta de concordância entre os diferentes indicadores no testemunho SAN76. De acordo com a razão G. bulloides/G. ruber e com a abundância relativa de foraminíferos bentônicos, o período mais produtivo na área do testemunho SAN76 teria sido no final do UMG, em torno de 19 mil anos AP. Já as abundâncias relativas de $G$. truncatulinoides (dex) e $N$. dutertrei para o mesmo testemunho sugerem um aumento da produtividade em torno de 8 mil anos AP. Durante este período os valores da razão $G$. bulloides/G. ruber também são relativamente altos embora o segundo pico de valores tenha ocorrido por volta de $10 \mathrm{mil}$ anos AP. No entanto, apesar das variações da composição de isótopos de carbono em G. ruber terem se mantido relativamente constantes ao longo do tempo elas mostram valores menores nesse mesmo período em torno de 10 mil anos AP. Os maiores valores da razão isotópica teriam ocorrido entre 4 e 2 mil anos AP, quando os demais indicadores sugerem uma baixa produtividade. Por último, a abundância relativa de ostracodes não apresentou variações significativas.

Finalmente, na Fig. 5.31 são comparadas as abundâncias relativas de fragmentos nos dois testemunhos analisados. Não foram observadas tendências claras ao longo do tempo nem uma correlação entre testemunhos. 

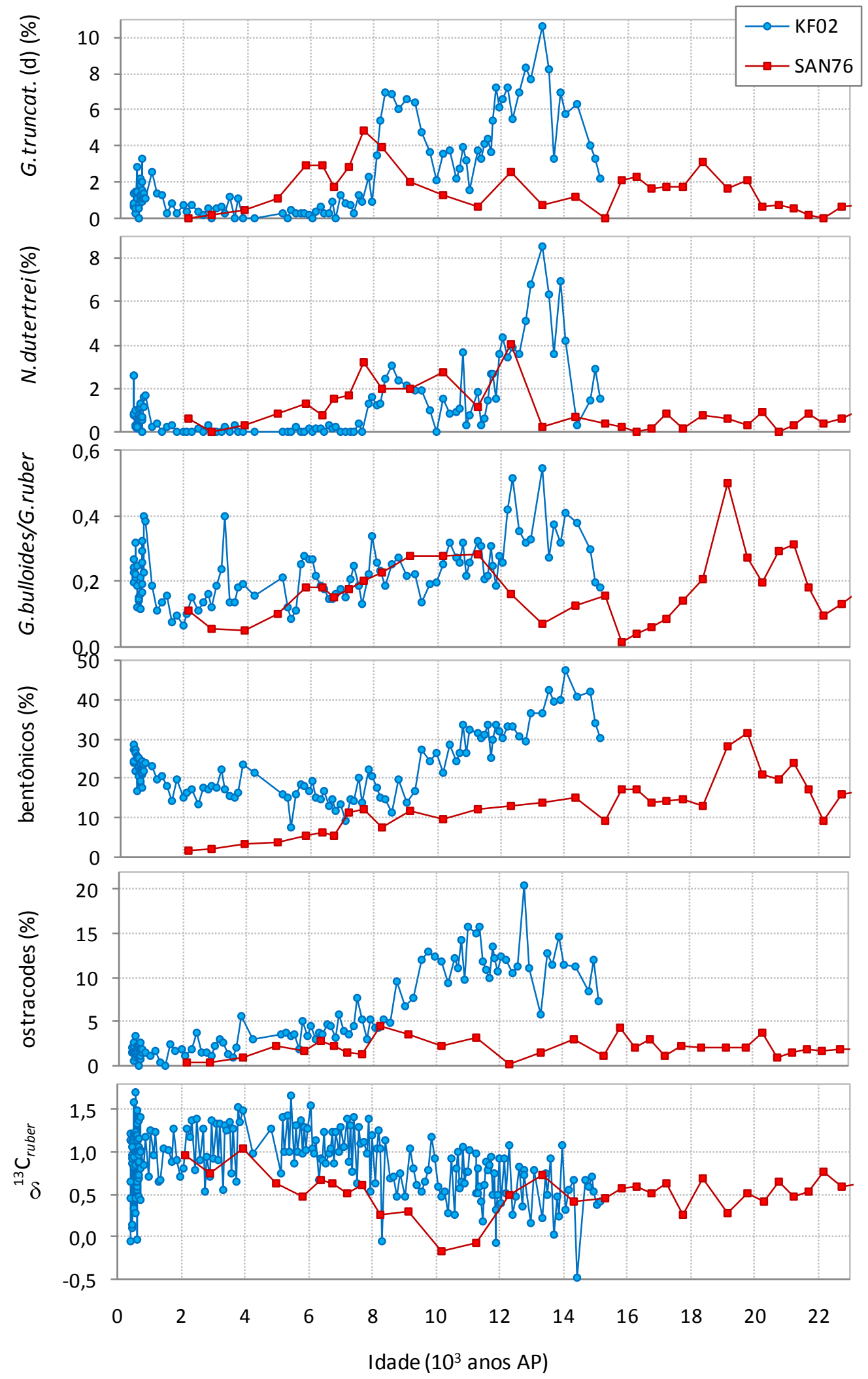

Fig. 5.30. Comparação das variações dos parâmetros relacionados à produtividade ao longo dos testemunhos KF02 e SAN76. De cima para baixo, os dados incluem: abundância relativa de $G$. truncatulinoides (dex) e $N$. dutertrei, razão G. bulloides/G. ruber, percentagem de foraminíferos bentônicos e ostracodes e composição de isótopos de carbono em testas de G. ruber (white). 


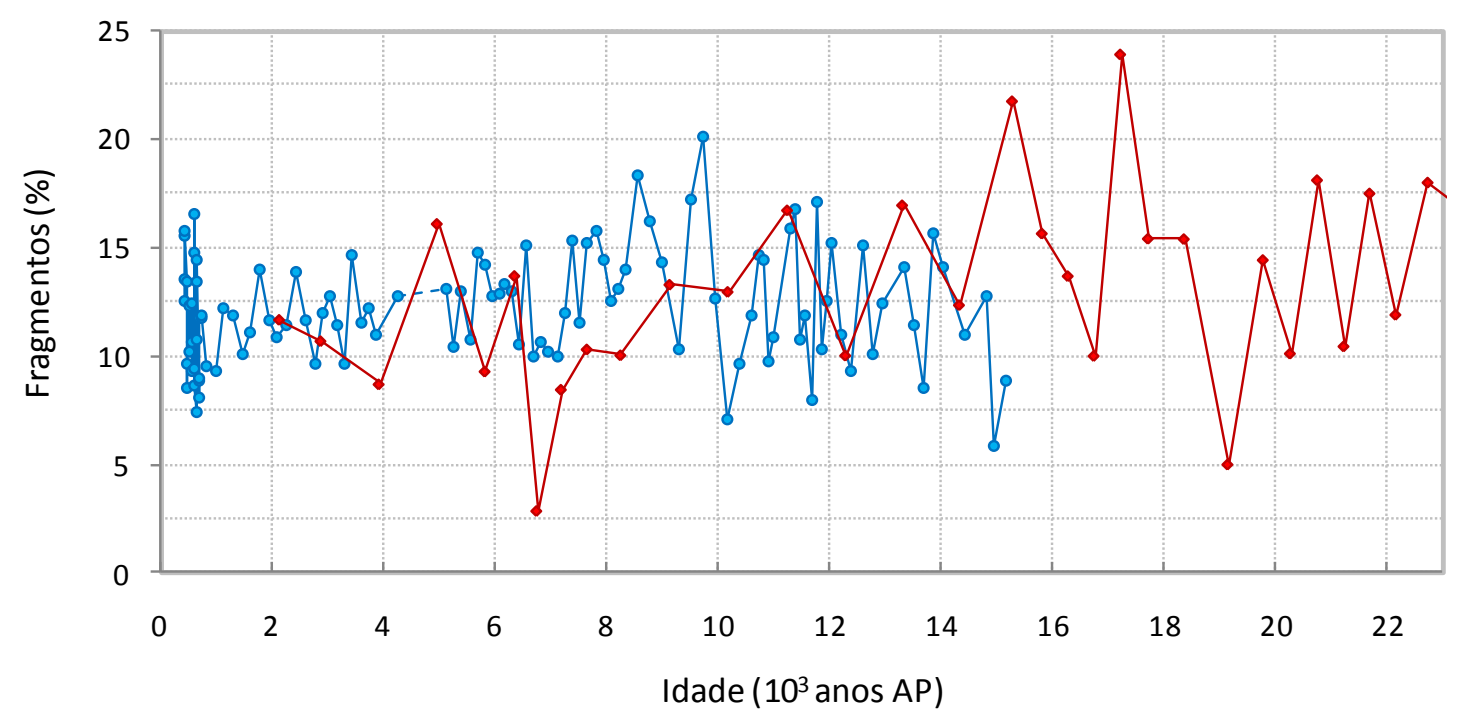

Fig. 5.31. Comparação das abundâncias relativas de fragmentos de foraminíferos planctônicos ao longo dos testemunhos KF02 e SAN76. 


\section{DISCUSSÃO}

Embora os testemunhos tenham sido coletados em locais próximos entre si, isto não significa que eles tenham experimentado as mesmas condições ambientais. De fato, conforme mencionado no capítulo 2, Mahiques et al. (2004) identificaram importantes diferenças entre ambas áreas as quais foram relacionadas a diferentes exposições ao fluxo da CB, ao aporte de águas do Rio da Prata e à ressurgência costeira. Desta forma, a diferença na localização dos testemunhos é vista como uma vantagem por fornecer indícios quanto à variabilidade e extensão geográfica dos diferentes processos atuantes ao longo do tempo.

Além da localização geográfica, as profundidades de coleta dos testemunhos também são convenientes por estarem muito acima da lisoclina tanto moderna como glacial (Frenz e Henrich, 2007) e, ao mesmo tempo, por serem o suficientemente profundas como para estar livres da influência da ação de ondas de tempestade mesmo sob condições de nível do mar mais baixo. Outro fator a ser levado em consideração é que, apesar de ter sido coletado em águas relativamente mais rasas (827 m de lâmina d'água), o local do testemunho KF02 encontra-se mais afastado da costa do que o do testemunho SAN76 o qual foi coletado em $1682 \mathrm{~m}$ de profundidade. A distância do local do testemunho KF02 até a costa é de aproximadamente $220 \mathrm{~km}$ enquanto no caso do testemunho SAN76, a distância é de $160 \mathrm{~km}$.

Comparadas às taxas de sedimentação do testemunho KF02, as taxas de sedimentação do testemunho SAN76 parecem pequenas, mas na maior parte dele se mantém taxas maiores do que $10 \mathrm{~cm} / 10^{3}$ anos o que minimiza potenciais problemas associados à bioturbação (Bard, 2001). As maiores taxas de sedimentação no testemunho KF02 podem ser explicadas pela localização em uma depressão batimétrica o que teria favorecido a deposição de sedimentos.

Milliman (1978) observa que, na área de estudo, o aporte de sedimentos teria sido maior em períodos glaciais devido ao rebaixamento do nível do mar. Este padrão é verificado no testemunho SAN76 (Fig. 5.20), mas não no testemunho KF02. Embora o testemunho KF02 não alcance a idade do mínimo regressivo para comparar melhor este efeito, observa-se que as maiores taxas de sedimentação ocorreram no final do registro, em condições de nível do mar semelhantes à atual. Além das variações do nível do mar, o aporte de sedimentos terrígenos e a produção biológica interferem significativamente 
nas taxas de sedimentação. Estes fatores devem ter sido os responsáveis pelas variações das taxas de sedimentação ao longo do tempo.

A comparação das taxas de sedimentação com as razões Ti/Ca e Fe/Ca para o testemunho KF02 (Fig. 6.1) sugere que os valores extremos do topo do testemunho sejam conseqüência de um aporte extremamente elevado de material terrígeno neste período. Os valores mínimos aproximadamente em torno de 9 mil anos AP no testemunho KF02 parecem ser o resultado da combinação de baixa produtividade de $\mathrm{CaCO}_{3}$ e baixo aporte de sedimentos terrígenos. Já, os valores baixos na base do testemunho parecem contradizer as razões elevadas de $\mathrm{Ti} / \mathrm{Ca}$ e $\mathrm{Fe} / \mathrm{Ca}$ e do teor de $\mathrm{CaCO}_{3}$. Uma possível explicação seria uma subestimação das taxas de sedimentação na base do testemunho uma vez que a amostra datada mais próxima à base é a de $436 \mathrm{~cm}$ de profundidade (idade estimada de 12766 anos AP) e desde esta amostra até a base, as idades das amostras foram estimadas assumindo uma taxa de sedimentação constante baseada no último segmento datado do testemunho. Levando em consideração esta hipótese, a correlação dos eventos identificados nesta seção do testemunho com eventos de outros registros deverá ser feita com cautela.

Analisando os dois testemunhos estudados, além das taxas de sedimentação serem menores no testemunho SAN76, o espaçamento entre as amostras é maior. Por exemplo, no Holoceno foram analisadas doze amostras no testemunho SAN76 em comparação a 90 amostras no testemunho KF02 (contabilizando aquelas para as quais foram estimadas paleotemperatura, paleossalinidade e paleoprodutividade). Da mesma maneira, o modelo de idade do testemunho KF02 é muito mais preciso e confiável do que o do testemunho SAN76. Por exemplo, se tem apenas uma datação no Holoceno do testemunho SAN76 (no topo do testemunho) e se tem sete datações para o mesmo período no testemunho KF02.

Nas seções a continuação são analisadas as estimativas obtidas respectivamente para paleotemperatura (seção 6.1), paleossalinidade (6.2) e paleoprodutividade (6.3) levando em consideração as limitações dos métodos utilizados. A discussão encerra com a seção 6.4 na qual os resultados são analisados em meio ao contexto regional e global, de acordo com o estado atual de conhecimentos para o período estudado. 

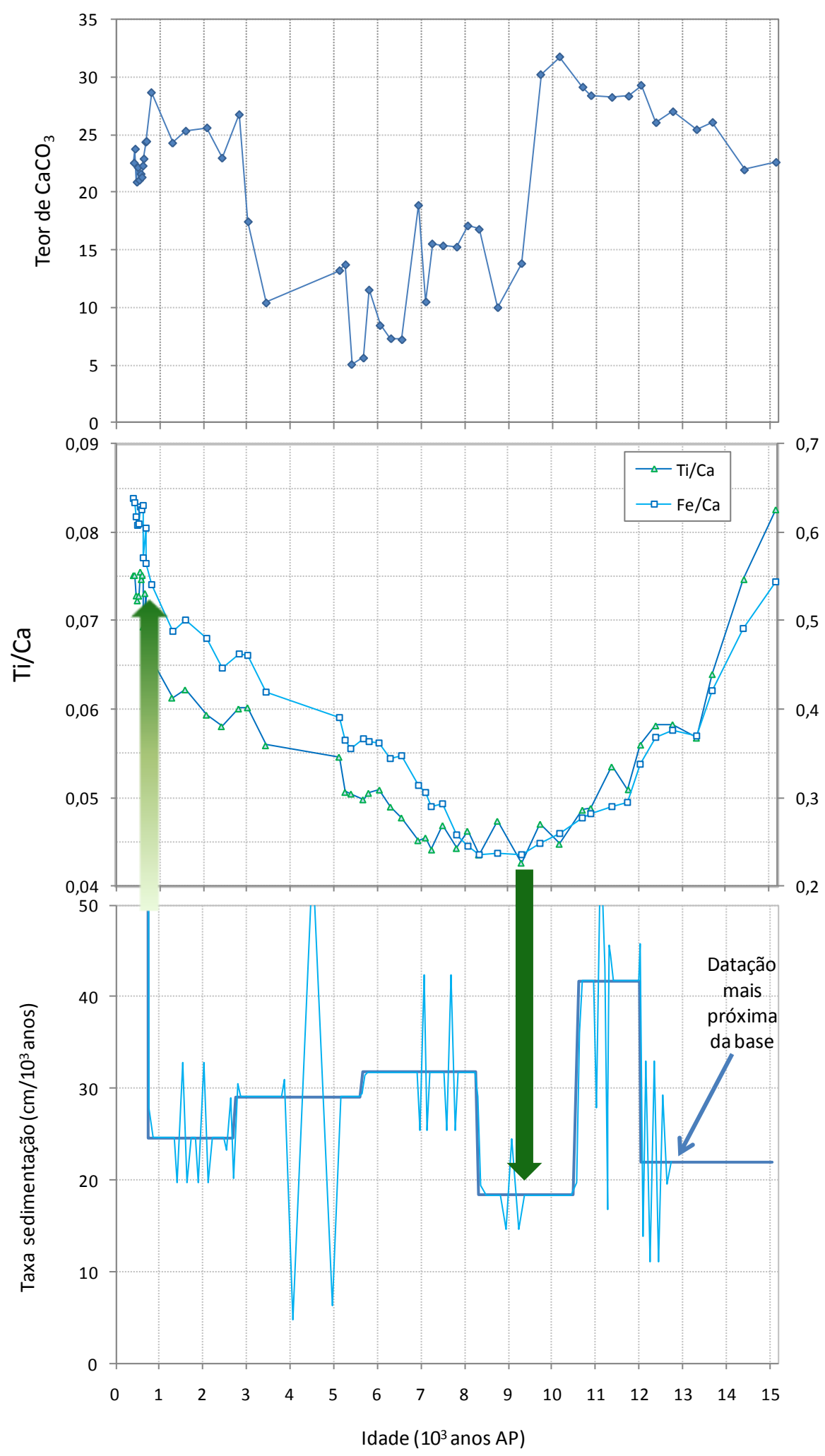

$\frac{\mathbb{D}}{2}$

Fig. 6.1. Comparação das taxas de sedimentação (gráfico inferior) com as razões $\mathrm{Ti} / \mathrm{Ca}$ e $\mathrm{Fe} / \mathrm{Ca}$ e o teor de $\mathrm{CaCO}_{3}$ medidos na fração fina (fração menor que $0,063 \mathrm{~mm}$ ) para o testemunho KF02. As setas verdes apontam os máximos e mínimos de taxas de sedimentação e a sua correlação com o aporte de sedimentos terrígenos de acordo com as razões Ti/Ca e Fe/Ca. 


\subsection{SOBRE A PALEOTEMPERATURA}

Antes de analisar as estimativas de paleotemperatura para o período estudado, duas importantes questões merecem destaque. Por um lado, a semelhança entre as estimativas para os dois testemunhos, apesar das fortes diferenças quanto às variações na composição faunal ao longo do tempo e, por outro, a observação das diferenças entre as estimativas fornecidas pelo método SIMMAX e pelas RNAs para o testemunho SAN76.

\subsubsection{Paleotemperaturas semelhantes para diferentes composições de fauna}

Conforme mencionado no capítulo anterior, considerando as limitações do modelo de idade do testemunho SAN76 (comparado à precisão do modelo KF02) e o espaçamento maior entre amostras consecutivas, a comparação das estimativas de paleotemperatura aponta para uma boa correlação entre testemunhos, principalmente no caso das estimativas de verão (Figs. 5.27 e 5.28). Certamente, dada a proximidade geográfica entre testemunhos esperava-se uma mesma tendência quanto às variações de temperatura. O que chama a atenção é o fato da semelhança entre as estimativas ter acontecido apesar das significativas diferenças nas variações de composição faunal (Figs. 5.23 a 5.25). O melhor exemplo disto é a concordância de um aumento de TSMs após 8 mil anos AP. No testemunho KF02, este aquecimento parece estar relacionado ao aumento da abundância relativa do Plexo menardiforme (Fig. 5.24). Já no testemunho SAN76, o Plexo menardiforme só aumenta em abundância relativa em torno de 6 mil anos AP, ou seja, aproximadamente 2 mil anos após o início do aquecimento.

A convergência nas estimativas de paleotemperatura dos dois testemunhos dá suporte à qualidade destes como registros paleoceanográficos na região. Já as diferenças na fauna demonstram que, além da temperatura da água, outros fatores influenciaram significativamente a distribuição e abundância das espécies. Estudos demonstram que, embora a distribuição geral esteja claramente relacionada à temperatura da água, existem múltiplos fatores que influenciam a abundância das espécies, incluindo a salinidade, a abundância e tipo de predadores presentes, a composição de nutrientes, a turbidez (ou transparência) da água e a hidrodinâmica das massas d'água reguladas pelos giros e zonas de convergência (Hemleben et al., 1989). 
De fato, uma das principais críticas que se faz ao uso de variações na composição faunal para estimar paleotemperaturas em baixas latitudes é a possível interferência de outros parâmetros ambientais, ou seja, até que ponto as variações na composição faunal refletem variações de temperatura e não variações de outros parâmetros ambientais tais como produtividade. Alguns autores (por ex. Ravelo et al., 1990; Andreasen e Ravelo, 1997) sugerem que, nos trópicos, mais do que a temperatura, a quantidade de nutrientes na coluna d'água possa ser o fator mais importante no controle da distribuição da fauna. No entanto, os baixos desvios das estimativas somados à concordância entre as paleotemperaturas estimadas para os dois testemunhos apesar das diferenças na fauna sugerem que, na área de estudo, as estimativas de paleotemperaturas baseadas na composição faunal são confiáveis.

\subsubsection{Comparação das estimativas das técnicas SIMMAX e RNAs}

A técnica SIMMAX é uma variante da Técnica do Análogo Moderno (Hutson, 1980) na qual os melhores análogos são escolhidos utilizando um Índice de Similaridade que confere um peso maior aos análogos geograficamente mais próximos à amostra fóssil. No entanto, sabemos que a relação entre parâmetros ambientais e localização geográfica variou ao longo do tempo, caso contrário não precisaríamos reconstruir TSMs (Kucera et al., 2005). Isto significa que o pressuposto geral da relação constante ao longo do tempo entre as variáveis do banco de dados de treinamento e as TSMs se justifica para as espécies de foraminíferos, mas não para informações geográficas, portanto, de acordo com Malmgren et al., (2001) o SIMMAX deveria ser utilizado apenas em reconstruções de TSMs do final do Holoceno.

Desta forma, poderíamos esperar uma menor concordância entre as estimativas do SIMMAX e das RNAs no Glacial comparadas às do Holoceno e, principalmente ao Holoceno superior, quando as condições teriam sido mais semelhantes às atuais. De fato, embora as diferenças entre as estimativas de paleotemperaturas fornecidas pelos dois métodos não tenham apresentado uma tendência temporal bem definida, no caso das estimativas de paleotemperatura de verão, observa-se uma discordância levemente maior entre as estimativas para o Glacial (Fig.6.2) No entanto, no caso das estimativas de inverno, as maiores discrepâncias ocorreram em amostras do Holoceno. 

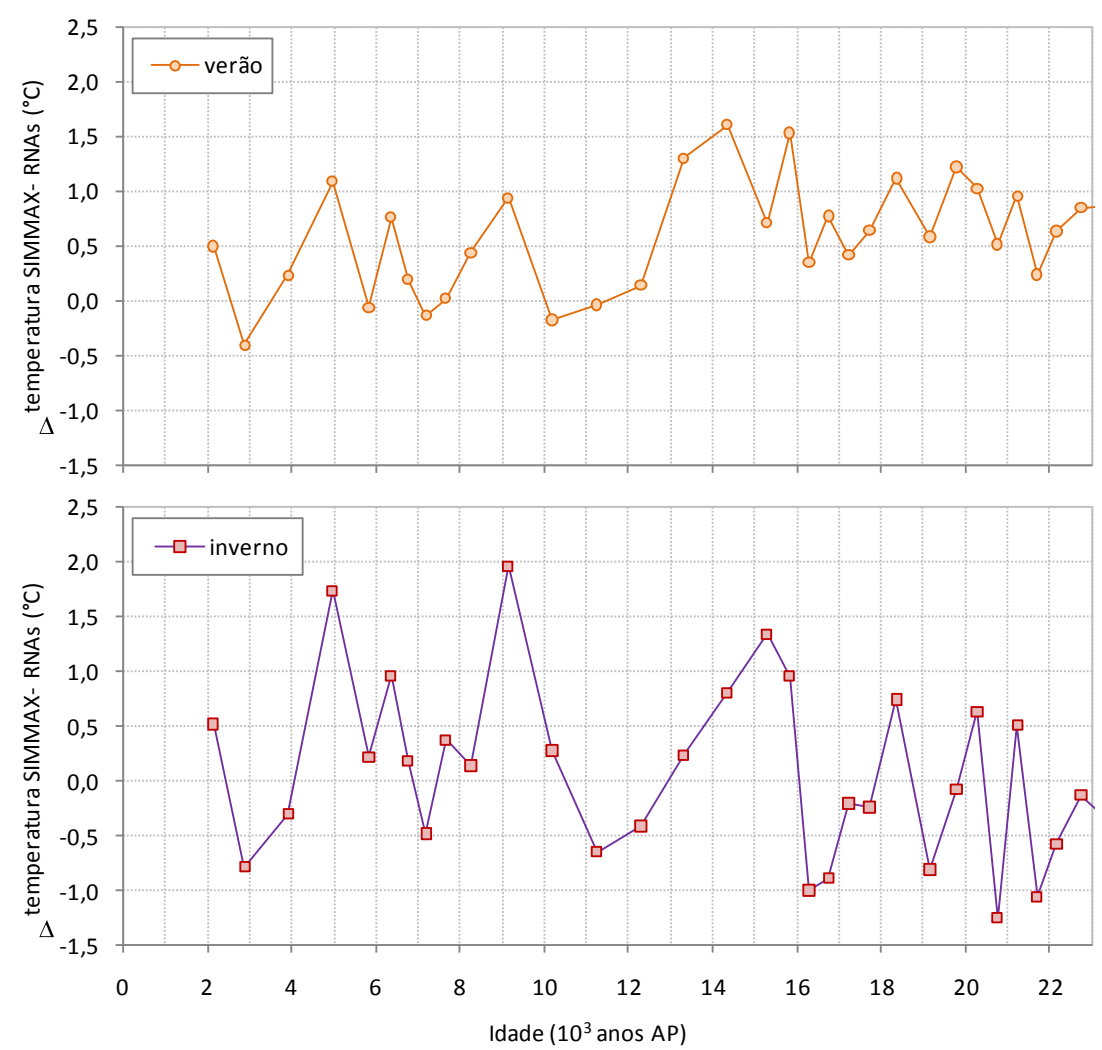

Fig. 6.2. Diferenças entre as estimativas de paleotemperatura baseadas nos métodos SIMMAX e RNAs para o testemunho SAN76, para o verão (acima) e inverno (abaixo). Manteve-se a mesma escala para uma melhor comparação.

Outra observação que surge da Fig. 6.2 é o fato das diferenças de estimativas de inverno serem maiores que as de verão. Isto era esperado conforme as próprias limitações dos métodos que prevêem uma menor precisão nas estimativas de inverno; fato que se corroborou pelos desvios padrão maiores das estimativas de paleotemperaturas de inverno (tabela 5.4). Observa-se também que, de maneira geral, as mesmas amostras que apresentaram maiores diferenças nas estimativas de verão foram as que apresentaram as maiores diferenças para o inverno. Isto sugere que tais amostras não possuem bons análogos modernos ou que não houve boa concordância entre os melhores análogos. 


\subsubsection{Variações de paleotemperatura}

Os mecanismos mais prováveis para explicar a variabilidade atual da TSM na área de estudo na escala interanual são mudanças na advecção de correntes oceânicas e variação da troca de calor entre o oceano e a atmosfera relacionada a processos atmosféricos (Venegas, 1995), os quais, na área de estudo, podem estar relacionados aos eventos ENOS (Lentini et al., 2001). De maneira análoga às variações atuais, as variações passadas podem estar relacionadas a mudanças na circulação oceânica e atmosférica e à entrada de outras massas d'água além da AT. Para explicar as variações ocorridas no período estudado devem ser considerados ainda fatores importantes como mudanças do nível do mar, mudanças na insolação e reorganizações da CTH. A identificação dos prováveis fatores responsáveis pelas mudanças de paleotemperaturas observadas, só é possível através da análise dos resultados no contexto dos demais dados disponíveis para a região e dados globais. Esta análise é apresentada na seção 6.4.

Como no período compreendido desde o UMG a Terra testemunhou mudanças climáticas extremas, a escala de variação também poderia ter sido maior do que a escala atual de variação interanual. No entanto, comparando as estimativas de verão obtidas com os valores médios modernos para a área de estudo (Figs. 5.27 e 5.28) e, principalmente, com as anomalias atuais de TSM na escala interanual (Fig. 6.3) se observa que as variações registradas para a estação quente nos testemunhos analisados foram relativamente modestas (amplitude máxima de $2,8^{\circ} \mathrm{C}$ ). Já no caso das estimativas de TSM média anual, a amplitude foi um grau maior $\left(3,8^{\circ} \mathrm{C}\right)$ e a amplitude das estimativas de inverno foi significativamente maior $\left(4,3^{\circ} \mathrm{C}\right)$, mas também os seus desvios. Por outra parte, as estimativas para verão, inverno e média anual mostram variações consistentes. Além disto, é importante lembrar que mesmo pequenas mudanças de TSM podem ter grande repercussão climática afetando significativamente a circulação atmosférica (Liu et al., 2003).

As estimativas sugerem um início do Holoceno mais frio que o atual e um posterior aumento de temperaturas a partir de aproximadamente 8 mil anos AP para valores mais elevados que os modernos durante todo o restante do Holoceno. Os menores valores de paleotemperatura teriam ocorrido em três momentos respectivamente em torno de 19, 14 e 8 mil anos AP. Isto significa que, de acordo com a definição cronológica do UMG do EPILOG (19 a 23 mil anos AP, seção 3.1), a maior parte do período definido globalmente como o UMG não teria sido a mais fria, fato que 
já foi observado em outras regiões (Mix et al., 2001). A estimativa de paleotemperatura média anual para a amostra de 19,2 mil anos de idade é de $22,54^{\circ} \mathrm{C}$ e para o verão e o inverno, respectivamente 24,84 e $21,49^{\circ} \mathrm{C}$. Comparando com os valores médios atuais segundo o WOA05, as anomalias estimadas para a amostra se 19,2 mil anos seriam de $1,06^{\circ} \mathrm{C}$ no verão, $-0,31^{\circ} \mathrm{C}$ no inverno e $-1,21{ }^{\circ} \mathrm{C}$ na média anual. No entanto, as estimativas do Projeto MARGO não se baseiam nos valores mínimos, mas sim na média dos valores das amostras com idades compreendidas entre 19 e 23 mil anos AP.
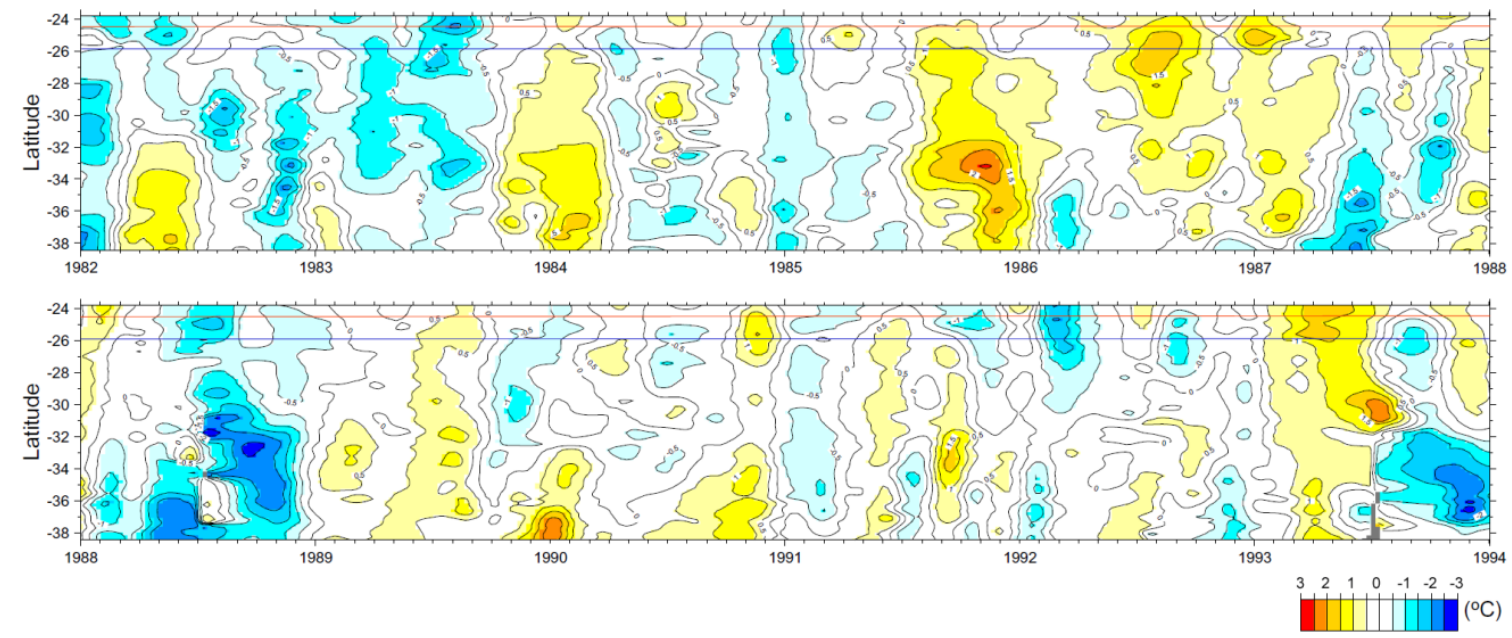

Fig. 6.3. Anomalias de TSM ao longo de um transecto sobre a plataforma continental desde a desembocadura do Rio da Prata até aproximadamente a latitude de localização do testemunho SAN76 para um período de 12 anos desde 1982 até 1995 (modificado de Campos et al., 1999; Lentini et al., 2001). Os autores computaram as séries temporais de anomalias de TSM após a exclusão da componente sazonal. As linhas azul e vermelha indicam respectivamente as latitudes dos testemunhos KF02 e SAN76.

Para a região de estudo, os resultados do Projeto MARGO se baseiam em registros de dois testemunhos sendo que em ambos foram estimados os índices $\mathrm{U}^{\mathrm{K}}{ }_{37}$ (Brassell et al., 1986; Prahl e Wakeham, 1987) (dados não publicados de P.J.Müller) e em um deles foi analisada a fauna de foraminíferos planctônicos (dados de Niebler et $a l ., 2003)$. O índice $\mathrm{U}^{\mathrm{K}}{ }_{37}$ se baseia na razão de insaturação de uma série de alquenonas de cadeia longa que são biossintetizadas por um grupo restrito de algas primnesiofitas, principalmente o cocolitoforídeo Emiliania huxleyi.

$\mathrm{O}$ valor final estimado pelo Projeto MARGO para a região corresponde à média destes três valores, com peso diferente para cada um deles segundo um índice de confiabilidade que leva em consideração o erro de calibração de cada proxy, a 
quantidade de amostras analisadas com idade dentro do período de interesse, o desvio das estimativas destas amostras e a qualidade dos modelos de idade dos testemunhos. No caso dos dados de foraminíferos, o modelo de idade era mais confiável do que nos dados de alquenonas, mas a diferença máxima das estimativas de TSM foi de entre 2 e $4^{\circ} \mathrm{C}$. A Tabela 6.1 resume as informações das estimativas do Projeto MARGO dos registros próximos à área de estudo.

Tabela 6.1. Estimativas de paleotemperaturas para o UMG das amostras do Projeto MARGO próximas à área de estudo.

\begin{tabular}{lcccc}
\hline Testemunho /Localização: & & $\begin{array}{c}\text { Temperatura } \\
\text { de verão }\left({ }^{\circ} \mathrm{C}\right)\end{array}$ & $\begin{array}{c}\text { Temperatura de } \\
\text { inverno }\left({ }^{\circ} \mathrm{C}\right)\end{array}$ & $\begin{array}{c}\text { Temperatura } \\
\text { média anual }\left({ }^{\circ} \mathrm{C}\right)\end{array}$ \\
\hline GeoB2107-3 (46,45W; 27,18S) & A & - & - & 20,3 \\
GeoB2109-1 (45,88W;27,91S) & A & - & - & 21,3 \\
GeoB2109-1 (45,88W;27,91S) & F & 24,93 & 20,55 & 22,59
\end{tabular}

$\mathrm{A}=$ alquenonas; $\mathrm{F}=$ foraminíferos.

Seguindo o método do Projeto MARGO, os valores médios das amostras com idades estimadas entre 19 e 23 mil anos AP foram comparados com os valores atuais de acordo com o WOA05 (Tabela 6.2). As anomalias estimadas são mínimas. Comparadas às estimativas do MARGO, os valores estimados para o UMG com os dados do testemunho SAN76 são de entre 2,6 e 3,6 $6^{\circ} \mathrm{C}$ maiores do que as estimativas baseadas em alquenonas e $1,28^{\circ} \mathrm{C}$ maiores que as estimativas baseadas em foraminíferos. Porém, cabe ressaltar que embora sejam próximos, os testemunhos analisados pelo Projeto MARGO são de latitudes maiores $\left(27,18\right.$ e $\left.27,9^{\circ} \mathrm{S}\right)$ que a do testemunho SAN76 $\left(24,44^{\circ} \mathrm{S}\right)$ o que certamente justifica boa parte desta diferença (ver Fig. 2.5).

Existem diversos fatores que podem explicar as diferenças entre as estimativas baseadas em alquenonas e aquelas baseadas em foraminíferos. Por um lado, à diferença das reconstruções de paleotemperatura baseadas nas variações de composição faunal, o índice $\mathrm{U}^{\mathrm{K}}{ }_{37}$ registra principalmente a temperatura da camada de mistura durante a estação de crescimento máximo de cocolitoforídeos. Isto significa que, se a espécie florescer na primavera, os valores registrados corresponderão a esta estação. Da mesma maneira, se a floração máxima estiver associada a períodos de ressurgência, os valores de temperatura registrados tenderão a ser menores. 
Tabela 6.2. Valores médios de paleotemperatura para as amostras pertencentes ao período entre 19 e 23 mil anos AP do testemunho SAN76 e anomalias em relação aos valores atuais definidos pelo WOA05.

\begin{tabular}{cccc}
\hline $\begin{array}{c}\text { Idade da amostra } \\
\left(10^{3} \text { anos AP }\right)\end{array}$ & $\begin{array}{c}\text { Temperatura de } \\
\text { verão }\left({ }^{\circ} \mathrm{C}\right)\end{array}$ & $\begin{array}{c}\text { Temperatura de } \\
\text { inverno }\left({ }^{\circ} \mathrm{C}\right)\end{array}$ & $\begin{array}{l}\text { Temperatura média } \\
\text { anual }\left({ }^{\circ} \mathrm{C}\right)\end{array}$ \\
\hline 19,2 & 24,84 & 21,49 & 22,54 \\
19,8 & 25,90 & 22,58 & 23,83 \\
20,3 & 26,09 & 21,89 & 23,76 \\
20,8 & 25,99 & 22,43 & 23,97 \\
21,2 & 26,16 & 22,02 & 23,87 \\
21,7 & 26,38 & 22,16 & 24,20 \\
22,2 & 26,53 & 23,62 & 24,78 \\
22,7 & 25,79 & 23,07 & 23,98 \\
\hline Valor médio: & $\mathbf{2 5 , 9 6}$ & $\mathbf{2 2 , 4 1}$ & $\mathbf{2 3 , 8 7}$ \\
\hline WOA05: & $\mathbf{2 5 , 9 0}$ & $\mathbf{2 1 , 8 0}$ & $\mathbf{2 3 , 7 5}$ \\
\hline Anomalia: & $\mathbf{- 0 , 0 6}$ & $\mathbf{- 0 , 6 1}$ & $\mathbf{- 0 , 1 2}$ \\
\hline
\end{tabular}

Por outro lado, um inconveniente do uso das alquenonas é o fato destas estarem contidas na fração mais fina dos sedimentos (Herbert, 2003) e, portanto, estarem mais sujeitas aos processos de ressuspensão, advecção e redeposição. Em muitos casos, isto se traduz em uma significativa defasagem espacial e temporal entre as alquenonas e os foraminíferos planctônicos coexistindo em uma mesma profundidade no sedimento (Ohkouchi et al., 2002, 2003; Mollenhauer et al., 2003). Como os dados de alquenonas compilados pelo Projeto MARGO não foram publicados separadamente, não se sabe ao certo como foi construído o modelo de idade. De acordo com as informações suplementares ao artigo publicado pelo Projeto MARGO (MARGO, 2009), sabe-se que a confiabilidade das idades estimadas para as amostras de alquenonas é menor do que a das amostras em que foram analisados foraminíferos, embora em um dos casos, se trate do mesmo testemunho.

Finalmente, ainda existem problemas de calibração na utilização das alquenonas para estimativas de paleotemperaturas. Por exemplo, em águas frias das altas latitudes, o índice de insaturação de alquenonas parece não ser influenciado apenas pela temperatura, mas também por outras variáveis ambientais e/ou biológicas (Bijma et al., 2001; Prahl et al., 2003). Embora isto não seja um problema para a nossa região, evidencia a necessidade de estudos específicos de calibração para cada região em que o índice é utilizado. 


\subsection{SOBRE A PALEOSSALINIDADE}

A composição de isótopos de oxigênio em G. ruber reflete principalmente a temperatura e a composição isotópica da água do mar circundante (neste caso, água superficial) no momento da calcificação da testa. Por este motivo, muitas vezes é utilizada como indicadora de paleotemperatura. No entanto, a comparação das variações de $\delta^{18} \mathrm{O}$ em $G$. ruber e as estimativas de paleotemperatura (Figs. 5.15, 5.26, 5.27 e 5.28 e Fig. 6.4) sugere que, no caso dos testemunhos analisados, mais do que variações de temperatura, a composição de isótopos de oxigênio em G. ruber seja o reflexo de variações na composição isotópica da água do mar as quais estão relacionadas com a paleossalinidade.

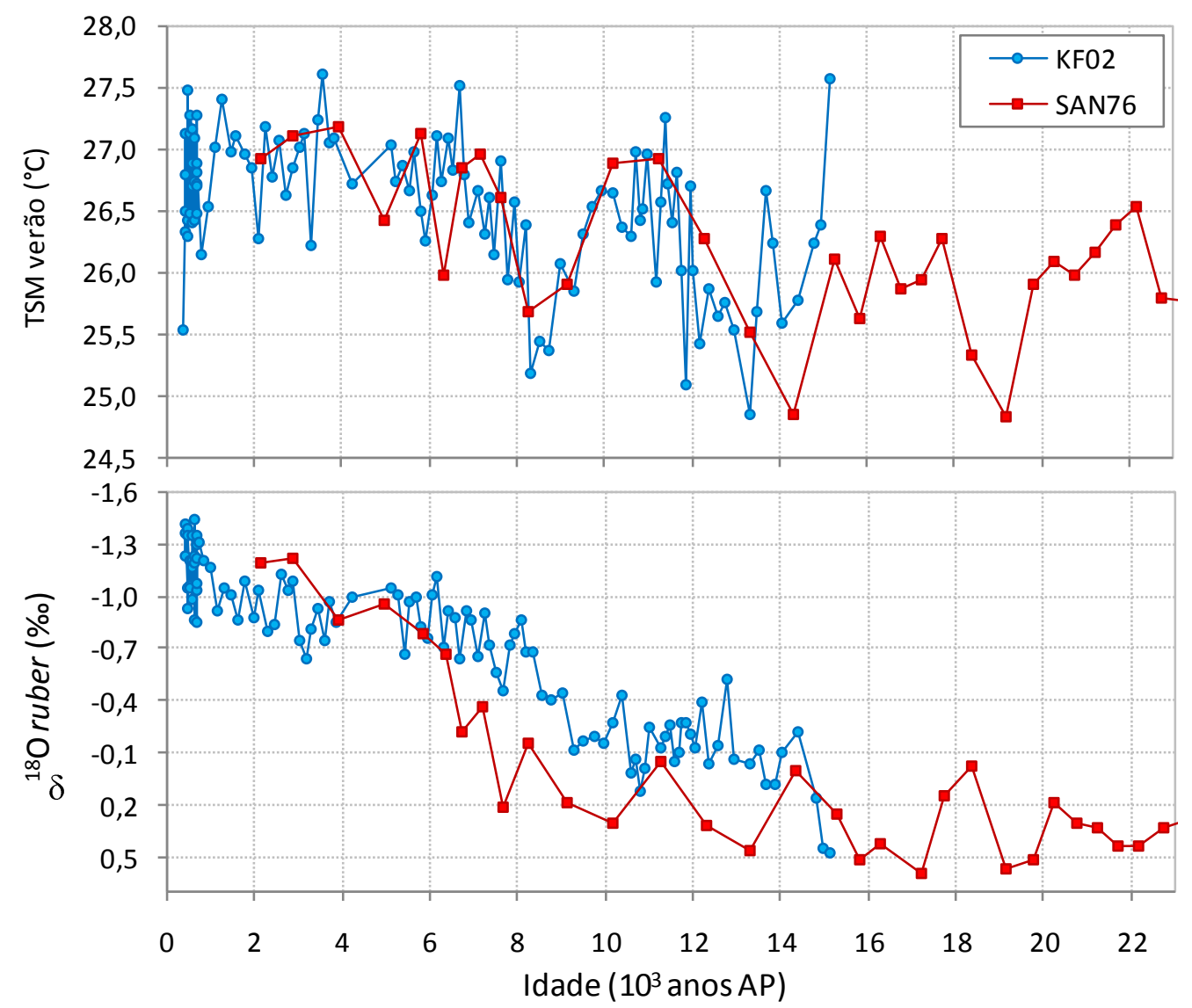

Fig.6.4. Comparação do registro de isótopos de oxigênio em G. ruber e as estimativas de TSM de verão baseadas nas RNAs para os dois testemunhos.

Dois aspectos chamam a atenção ao olharmos as estimativas de paleossalinidade da Fig. 5.29. Por um lado, os valores elevados de SSM para todo o período analisado; valores que ficam acima dos valores modernos para a área de estudo. Este fato é 
comentado na seção 6.2.1 onde são discutidas as limitações do método. Por outro lado, chama a atenção que, apesar da ótima correlação entre as estimativas de paleotemperatura para os dois testemunhos (seção 6.1), de maneira geral, não se observou uma concordância tão clara para as estimativas de paleossalinidade. Chama a atenção principalmente a tendência tardia à diminuição de salinidade no testemunho SAN76 quando comparado ao testemunho KF02 (Fig. 5.29). O assunto é abordado na seção 6.2.2.

\subsubsection{As limitações do método residual de isótopos de oxigênio}

Conforme foi mencionado na seção 4.4.2, a confiabilidade das estimativas de paleossalinidade obtidas com o método residual é limitada principalmente pelo erro associado às estimativas de paleotemperatura e pelas limitações da relação entre a composição isotópica da água do mar e a salinidade utilizada. Apesar disto, dada a importância da salinidade, mesmo uma estimativa semiquantitativa é válida (Mix et al., 2001) o que justifica a aplicação do método.

Embora a salinidade e a composição isotópica da água do mar sejam afetadas pelos mesmos processos de evaporação, precipitação e mistura com águas de diferentes origens, a relação entre ambas variáveis não é constante. A relação é quase linear, mas variável geograficamente em função das características gerais da evaporação e precipitação da área considerada (Craig e Gordon, 1965). Em águas superficiais, a pendente varia entre 0,1 em águas tropicais até $1 \mathrm{em}$ altas latitudes (Paul et al., 1999). A diferença essencial entre ambas variáveis é que, enquanto o sal constitui um traçador do fluido oceânico como um todo, a composição isotópica da água constitui, especificamente, um traçador da água que compõe esse fluido (Craig e Gordon, 1965). Isto significa que a salinidade depende apenas da quantidade de água envolvida no balanço hídrico, enquanto que a composição isotópica da água do mar depende também da qualidade isotópica desta água.

A pendente da relação entre salinidade e composição isotópica da água do mar representa uma relação espacial válida para uma determinada região. A relação temporal, ou seja, de quê maneira a relação variou ao longo do tempo, é muito mais difícil de determinar (Delaygue et al., 2001; Schmidt, 1999). Talvez a maior limitação do método residual seja a de assumir que a relação espacial se manteve constante ao longo do tempo, o que dificilmente tenha acontecido. No mínimo, a relação deve ter 
sido modificada por variações globais em função de variações no volume de gelo. Tomando o exemplo do UMG, sabemos que a salinidade global aumentou em torno de 1.2 devido à descida do nível do mar (Fairbanks, 1989) e que a composição isotópica da água do mar aumentou $1.05 \pm 0.20 \%$ (Duplessy et al. 2002) devido ao acúmulo preferencial do isótopo leve nos mantos de gelo. Se não houvesse outros fatores envolvidos, estas variações globais teriam simplesmente mudado a relação entre a composição isotópica da água do mar e a salinidade para uma glacial de mesma pendente (Schäfer-Neth, 1998) (Fig. 6.5). Porém, muito provavelmente tenham existido outras variações regionais causando mudanças na pendente da relação. Por outra parte, a composição isotópica da água do mar também depende de processos de advecção e mistura de massas d'água de diferentes origens (Rohling e Bigg, 1998; Rohling e Cooke, 1999). Isto significa que, ao usarmos uma relação "local" entre a composição isotópica da água do mar e a salinidade, assume-se que ela reflete o balanço hídrico local e desconsideram-se os processos de advecção e mistura que em alguns casos podem ser importantes (Rohling e Bigg, 1998; Wadley et al., 2002).

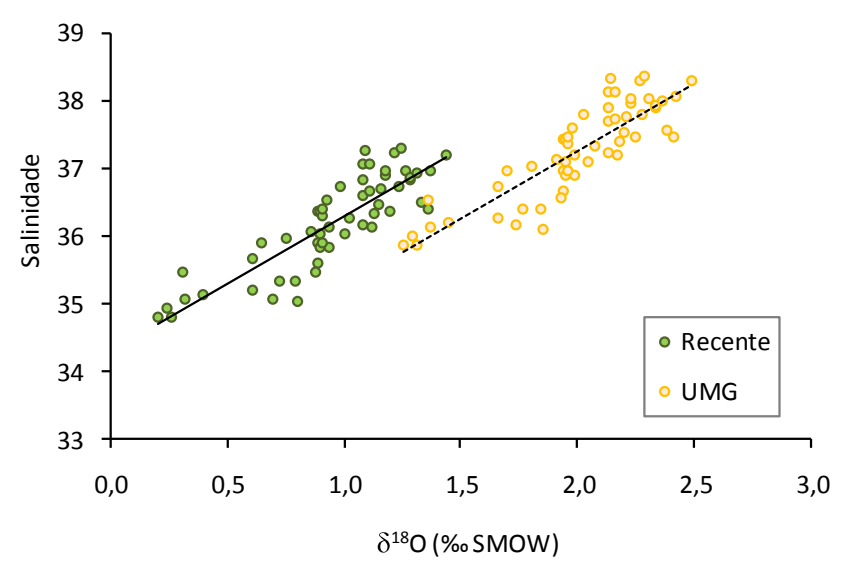

Fig. 6.5. Pendente da relação entre a composição isotópica da água do mar na área de estudo para o oceano moderno e para o UMG, considerando apenas o aumento do volume de gelo e conseqüente aumento de salinidade (Toledo et al., 2007b).

A Fig. 6.6 mostra a influência do uso de diferentes relações entre $\delta^{18} \mathrm{O}$ da água do mar e a salinidade nas estimativas de paleossalinidade (Toledo et al., 2007b). Embora os valores absolutos resultantes da aplicação das diferentes relações sejam bastante diferentes, as tendências de variação são as mesmas. Dadas as limitações do método, é isso o que se espera dele, ou seja, pretende-se que o método forneça informações quanto aos padrões de variação e não valores absolutos. A relação 
escolhida entre o $\delta^{18} \mathrm{O}$ da água do mar e a salinidade utilizada neste trabalho corresponde àquela baseada em dados do Atlântico Sul, entre o equador e $45^{\circ}$ de latitude. Esta relação foi escolhida por ser a que apresentou as melhores correlações entre as alternativas testadas e porque, quando aplicada nas estimativas de paleossalinidade, foi a que forneceu os valores mais próximos da realidade.
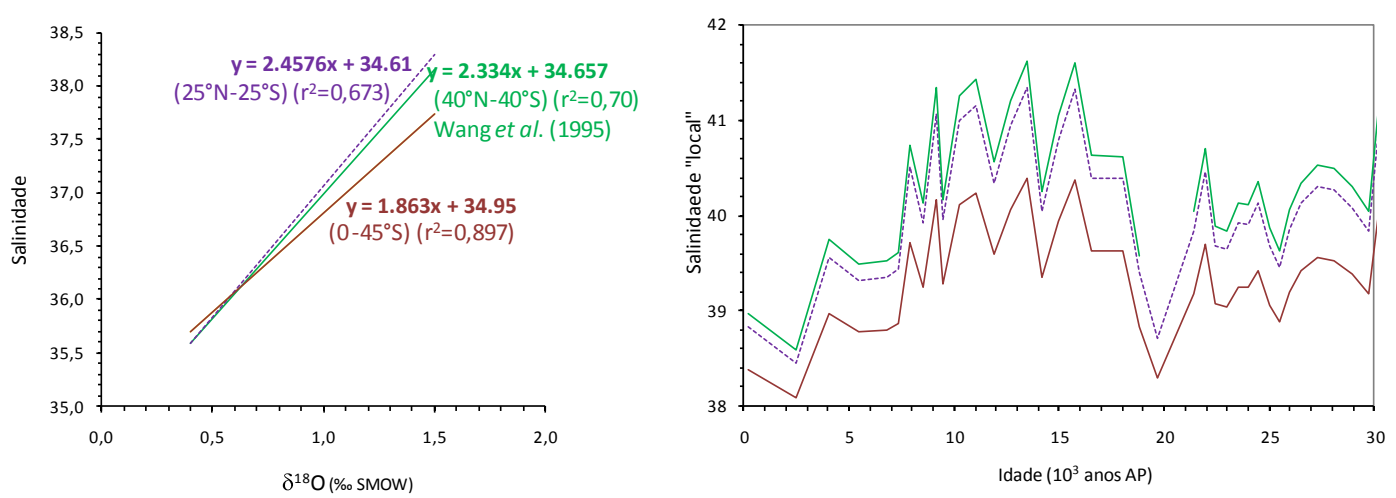

Fig. 6.6. Diferentes relações entre salinidade e $\delta^{18} \mathrm{O}$ da água do mar para o Oceano Atlântico (à esquerda) e os seus efeitos nas estimativas de paleossalinidade (à direita). Adaptado de Toledo et al. (2007b). Todos os dados correspondem a profundidades entre 0 e $250 \mathrm{~m}$.

\subsubsection{Variações de paleossalinidade}

Quais são as possíveis explicações para as discrepâncias nas variações de paleossalinidade levando em consideração que as estimativas de paleotemperatura são coincidentes? De maneira geral, as variações de salinidade superficial estão relacionadas a variações latitudinais no balanço entre precipitação $(\mathrm{P})$ e evaporação $(\mathrm{E})$ (Fig. 6.7). Desvios deste padrão ocorrem devido à influência dos continentes e das correntes oceânicas e atmosféricas. Desta forma, uma possibilidade seria a influência de águas costeiras diferente para as áreas dos dois testemunhos. Neste caso, a influência teria sido maior no local do testemunho KF02 durante a transição PleistocenoHoloceno e menor no Holoceno superior quando comparado ao testemunho SAN76.

Analisando o diagrama T-S da Fig. 2.9, se observa que, eventualmente, as águas costeiras pouco salinas podem ter temperaturas semelhantes à AT embora este não seria o caso da intrusão de águas provenientes da Bacia do Prata as quais se caracterizam por baixas temperaturas e salinidades (Fig. 2.12). Por outro lado, as razões Ti/Ca e Fe/Ca ao 
longo do testemunho KF02 (Fig. 5.17) parecem contradizer esta idéia por sugerirem uma maior influência continental no final do Holoceno e menor influência durante a transição Pleistoceno-Holoceno. No entanto, deve se lembrar que, caso o aporte de sedimentos terrígenos esteja relacionado à vazão do Rio da Prata, este deve ser um aporte fortalecido no inverno, quando a pluma se estende mais ao norte graças à ação de ventos favoráveis (Campos et al., 1999; Piola et al.; 2000) enquanto as estimativas de paleossalinidade são para a estação de verão.

(a)

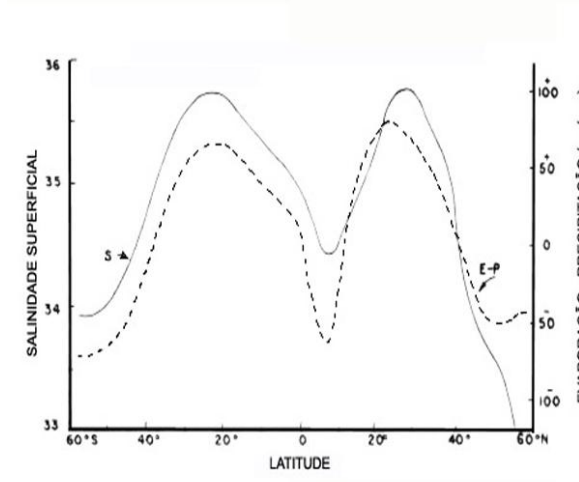

(b)

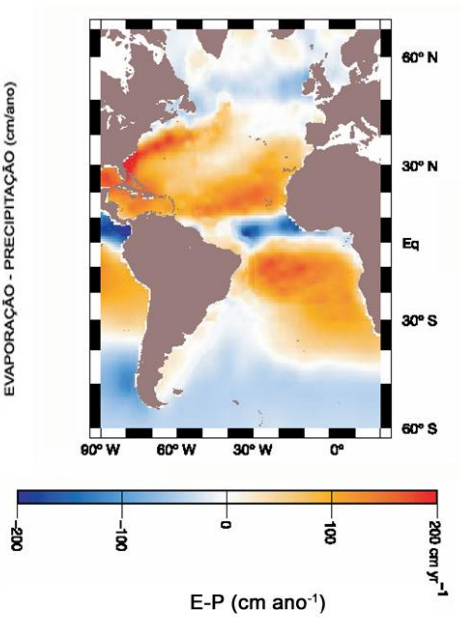

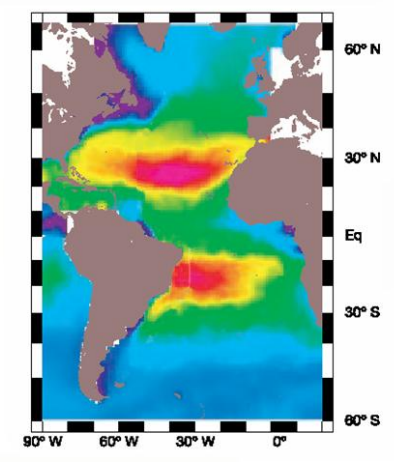

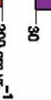

西

Fig. 6.7. Relação entre salinidade e balanço E-P: (a) Variação da salinidade superficial média de todos os oceanos e do balanço E-P em função da latitude (Pickard e Emery, 1990), (b) salinidade superficial e balanço E-P no Oceano Atlântico (Curry et al., 2003). Observa-se a forte correlação entre a salinidade e o balanço E-P e a influência das correntes oceânicas na suavização e deslocamento dos valores máximos subtropicais.

Outra possibilidade seria a influência de um balanço hídrico diferente na região de cada testemunho. Considerando que no oceano Atlântico o balanço entre precipitação e evaporação reflete fortemente a distribuição da precipitação devido à variabilidade muito menor da evaporação comparada à precipitação (Tomckzak e Godfrey, 2001) pode-se considerar as variações como o produto de diferentes regimes pluviométricos. Embora muito próximos, o testemunho SAN76 está localizado exatamente na área de influência atual da ZCAS (Fig. 2.4) e, em função desta localização, pode-se esperar uma variabilidade relacionada à atividade desta zona de convergência.

Evidentemente, o efeito de um aumento da precipitação seria uma diminuição da salinidade e dos valores de $\delta^{18} \mathrm{O}$ da água do mar. No caso da precipitação associada à 
ZCAS a diminuição seria intensificada ainda pela composição isotópica da precipitação. Esta se caracteriza por baixos valores de $\delta^{18} \mathrm{O}$ resultantes por um lado do longo percurso do vapor d'água desde a Amazônia até os subtrópicos através do jato de níveis baixos (Cruz et al., 2005b, 2006) e, por outro, do "efeito da quantidade" (“amount effect") segundo o qual, quanto maior o volume de precipitação, maior o empobrecimento em isótopos pesados (Dansgaard, 1964; Gat et al., 2001, Vuille e Werner, 2005). Isto significa que, se tiver ocorrido uma alteração da composição isotópica da água do mar em função de um aumento da precipitação de monção, esta deve ter ficado registrada como uma importante diminuição dos valores de $\delta^{18} \mathrm{O}$ da água do mar.

Numerosos trabalhos têm demonstrado a influência da insolação de verão na determinação da intensidade dos sistemas de monção ao redor do mundo (por ex. Kutzbach e Otto-Bliesner, 1982; Prell e Kutzbach, 1987; Valdes e Glover, 1999; Liu et al., 2003). Uma vez que a atividade da ZCAS está diretamente relacionada à intensidade do SMAS (seção 2.2.1), decidiu-se comparar os resultados com dados da variação da insolação para a área de estudo. Para dar mais confiabilidade à análise, dadas as limitações do uso de uma relação entre $\delta^{18} \mathrm{O}$ da água do mar e salinidade para o cálculo de paleossalinidade (seção anterior) foram utilizadas simplesmente as estimativas da composição isotópica da água do mar antes da transformação destes valores em estimativas de paleossalinidade (antes do uso da equação 4 da seção 4.4.2). Desta forma, evita-se o emprego da relação entre composição isotópica da água do mar e salinidade com as limitações que a sua aplicação implica.

A Fig. 6.8 apresenta as estimativas de composição isotópica da água do mar para os testemunhos SAN76 e KF02 após a extração do volume de gelo global. Observa-se uma tendência a valores máximos (lembrando que a escala está invertida) entre 12 e 10 mil anos AP. Ao compararmos esta variação às curvas de insolação de verão para esta latitude na mesma figura, se observa uma boa correlação com os dados do testemunho SAN76 $(\mathrm{R}=-0,72$ e $-0,73$ respectivamente em relação à insolação de dezembro e janeiro). Já a correlação com a curva do testemunho KF02 não é tão clara embora valores baixos coincidam com o mínimo de insolação $(\mathrm{R}=-0,5$ e $-0,34$ respectivamente em relação à insolação de dezembro e janeiro). 


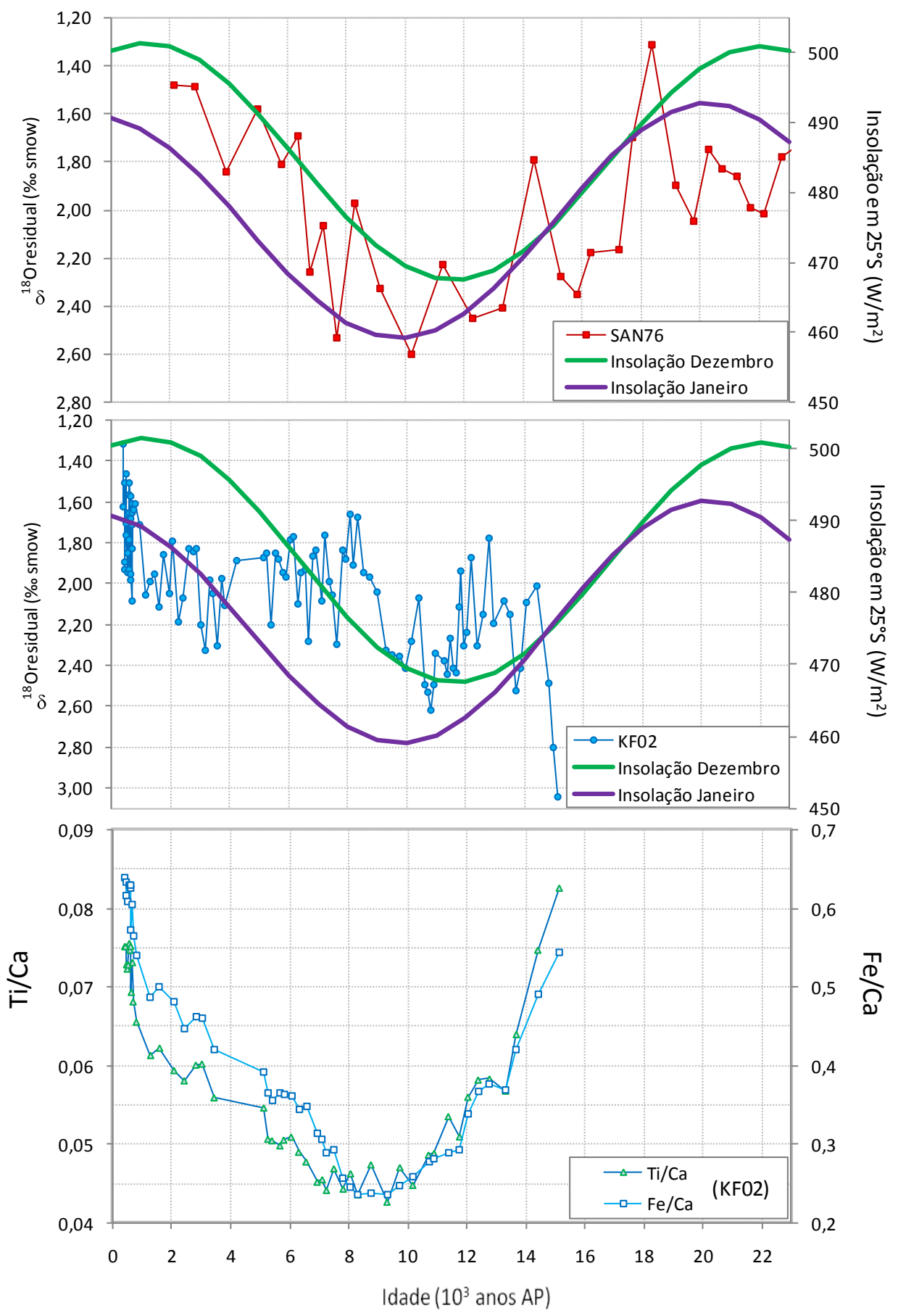

Fig. 6.8. Comparação das estimativas de composição isotópica da água do mar para os dois testemunhos e a variação da insolação de dezembro e janeiro em $25^{\circ} \mathrm{S}$ (testemunho SAN76 no gráfico superior, e testemunho KF02 no gráfico intermediário) e variações das razões Ti/Ca e $\mathrm{Fe} / \mathrm{Ca}$ para o testemunho KF02 (gráfico inferior). Os dados de insolação foram obtidos com o uso do programa desenvolvido pelo Prof. L.D.Roper (Virginia Polytechnic Institute and State University) de acordo com a solução de Berger (1978), programa disponível na página web http://arts.bev.net/roperldavid/InsolationCodes.htm. 
Apesar do testemunho SAN76 estar atualmente na área de influência direta da ZCAS, isto não significa que tenha sido assim durante todo o período analisado, principalmente se considerarmos as variações de insolação. No entanto, a melhor correlação com o testemunho SAN76, é um indício de que esta área tenha sofrido uma maior influência da ZCAS durante todo este período. Apesar disto, o testemunho KF02 também deve ter sido influenciado ao menos indiretamente por processos advectivos.

Assumindo então que as variações na composição isotópica da água do mar estimadas para o testemunho SAN76 refletem em boa parte variações na precipitação de monção vemos que, como esperado, o mínimo de atividade teria ocorrido em torno de 12 mil anos AP, quando o contraste termal entre o mar e o continente era menor.

Na mesma Fig. 6.8 as estimativas são comparadas às variações das razões Ti/Ca e Fe/Ca ao longo do testemunho KF02. Observa-se uma correlação muito clara com valores mínimos coincidentes com o mínimo de insolação e valores máximos nos períodos para os quais foi estimado um regime de maior precipitação local. A maior correlação é entre a curva da razão $\mathrm{Fe} / \mathrm{Ca}$ e a insolação de janeiro $(\mathrm{R}=0,87)$. A excelente correlação leva a pensar que o aporte de sedimentos terrígenos esteja relacionado à drenagem da área continental adjacente aos testemunhos. No entanto, não podemos descartar a influência remota do Rio da Prata, levando em conta primeiro que o aporte de sedimentos terrígenos à margem continental na área de estudo é limitado; segundo, que a descarga do principal tributário da Bacia do Prata que é o Rio Paraná e o Rio Paraguai está diretamente associada à atividade da ZCAS (Robertson e Mechoso, 2000) e, terceiro que existem evidências de um aporte atual de sedimentos do Rio da Prata na região do testemunho KF02 (Mahiques et al., 2004).

\subsection{SOBRE A PALEOPRODUTIVIDADE}

Conforme observado na seção 6.1 as estimativas semelhantes de paleotemperaturas para os dois testemunhos apesar das diferenças na composição faunal, sugerem que outros fatores influenciaram significativamente a distribuição e abundância das espécies. De acordo com as observações de Kemle-von-Mücke e Hemleben (1999), embora na escala global a temperatura constitua o principal parâmetro determinante da distribuição e abundância de espécies, dentro de uma determinada região, a distribuição de foraminíferos passa a ser fortemente dependente 
da disponibilidade de nutrientes. Isto significa que, muito provavelmente, as diferenças na fauna entre testemunhos estejam relacionadas a variações na disponibilidade de nutrientes. De acordo com Ravelo et al., (1990) e Ravelo e Andreasen (1999) a influência da disponibilidade de nutrientes na composição faunal é particularmente importante em baixas latitudes, onde a estrutura vertical da coluna d'água parece ter um papel crucial neste processo.

As Figs. 5.16 e 5.30 mostram que não houve uma perfeita concordância entre os diferentes indicadores de paleoprodutividade analisados. Isto era esperado, uma vez que nenhum deles depende exclusivamente da produtividade. Por outro lado, os indicadores sugerem que, apesar de próximas, as áreas dos dois testemunhos analisados experimentaram diferentes condições de fertilidade e produtividade ao longo do período estudado. Os fatores que influenciam o registro de cada um destes indicadores são apresentados na seção 6.3.1. Já a análise detalhada destas variações é apresentada na seção 6.3.2.

\subsubsection{Sobre os indicadores utilizados}

Existe uma clara relação entre a fertilidade de uma massa d'água e ao menos os níveis tróficos mais baixos do zooplâncton os quais incluem os foraminíferos planctônicos (Bijma et al., 1992). Dentre os indicadores utilizados nesta parte do trabalho, a composição de isótopos de carbono em G. ruber é o único que constitui diretamente um indicador de fertilidade.

A composição de isótopos de carbono em foraminíferos planctônicos reflete a composição isotópica da água do mar a qual, por sua vez, depende de uma série de fatores atuando em diversas escalas (Rohling e Cooke, 1999). Um dos processos que influem na composição de isótopos de carbono é a fotossíntese, devido ao uso preferencial de ${ }^{12} \mathrm{C}$ na formação de matéria orgânica. Isto significa que quanto maior a atividade fotossintética e, portanto, maior a produção, maior é a exportação de ${ }^{12} \mathrm{C}$ deixando uma maior proporção de ${ }^{13} \mathrm{C}$ disponível na água. Por este motivo, as águas superficiais tendem a ser enriquecidas no isótopo pesado quando comparadas às águas subsuperficiais. O inconveniente é que, muitas vezes, a fertilização das águas superficiais está relacionada a eventos de ressurgência. Isto significa que, enquanto por um lado o aumento de produção leva a um aumento de $\delta^{13} \mathrm{C}$, por outro, a elevação de água subsuperficial (na qual já ocorreram os processos de remineralização) leva a uma 
diminuição dos valores de $\delta^{13} \mathrm{C}$ o que dificulta a interpretação do sinal isotópico (Wefer et al., 1999).

$\mathrm{O}$ registro de isótopos de carbono também é afetado pela utilização de $\mathrm{CO}_{2}$ metabólico durante a formação da testa, pela atividade de simbiontes (lembrando que $G$. ruber têm simbiontes), pelas taxas de crescimento e por variações na concentração do íon carbonato na água circundante (Rohling e Cooke, 1999). Conseqüentemente, muitas vezes são detectados desvios significativos do equilíbrio em função do estágio ontogenêtico do organismo o que se traduz em uma clara relação entre desvios isotópicos e tamanho das testas, tal como foi verificado por Fraguas (2009).

Por outra parte, sabe-se que ocorreram variações globais nos valores de $\delta^{13} \mathrm{C}$ nas testas carbonáticas com menores valores no glacial e maiores valores no interglacial as quais têm sido atribuídas a variações globais dos valores médios de $\delta^{13} \mathrm{C}$ relacionadas à transferência e remineralização de matéria orgânica de origem terrestre rica em ${ }^{12} \mathrm{C}$ para o reservatório oceano-atmosfera glacial (Shackleton, 1977) e a variações na concentração do íon carbonato ou pH (Spero et al., 1999).

À diferença dos isótopos de carbono, os quais constituem um indicador de fertilidade, os demais indicadores de paleoprodutividade utilizados foram parâmetros faunais dos quais se espera observar a resposta às variações de fertilidade.

Por muito tempo, houve controvérsia quanto à existência ou não de diferentes espécies de G. truncatulinoides, embora existam evidências da existência de subpopulações há mais de vinte anos (por ex. Healy-Williams et al., 1985). Com o avanço das pesquisas genéticas, de Vargas et al. (2001) demonstraram que, na realidade, G. truncatulinoides corresponde a um complexo de quatro espécies adaptadas a condições hidrográficas específicas. Duas delas são características de águas frias e habitam respectivamente a convergência subantártica e a zona subantártica. As outras duas espécies são características de águas mais quentes e as suas preferências ecológicas não são tão bem definidas. Uma destas espécies de águas cálidas é a única que inclui tanto espécimes dextrógiros quanto levógiros já que as demais apresentam apenas enrolamento para a esquerda. Das espécies de águas quentes, a que apresenta apenas enrolamento para a esquerda aparentemente habita as áreas oligotróficas características dos centros dos giros subtropicais, enquanto a outra espécie (a que inclui espécimes dextrógiros) está associada a ambientes mais produtivos tais como as margens dos giros 
subtropicais (Renaud e Schmidt, 2003). Por este motivo, pode-se considerar Globorotalia truncatulinoides (dex) como indicadora de produtividade.

A abundância desta espécie também tem sido utilizada como indicadora da mistura vertical das águas superficiais (Mulitza et al., 1997; Dürkoop et al., 1997, Toledo et al., 2007b). Estudos mostram que, em baixas latitudes, G. truncatulinoides habita em maiores profundidades exceto durante o início da primavera austral, quando os espécimes ascendem na coluna d'água como parte do seu ciclo reprodutivo, descendendo novamente durante o verão e outono (Hemleben et al., 1989). O grau de mistura das águas superficiais é, portanto, fundamental para que os juvenis desta espécie possam ascender e continuar o seu ciclo de vida (Lohmann e Schweitzer, 1990) o que faz com que a distribuição da espécie seja muito mais dependente do grau de mistura vertical do que da temperatura (Lohmann, 1992).

Assim como G. truncatulinoides (dex), a espécie $N$. dutertrei também é comumente associada à alta produtividade (Hilbrecht, 1997). As diatomáceas constituem a sua principal fonte de alimento (Hemleben et al., 1989). A abundância desta espécie está associada à subida e descida da termoclina em relação à zona eufótica (Bé et al., 1985). No entanto, de acordo com Sautter e Thunnel (1991), mais do que durante os eventos de ressurgência, a abundância de $N$. dutertrei tende a aumentar logo após estes eventos, quando a concentração de fitoplâncton ainda é elevada, mas quando a coluna d'água já apresenta certa estratificação e estabilidade.

Embora alguns autores tenham sugerido que a abundância de $N$. dutertrei seja favorecida por baixas salinidades (por ex. Cullen, 1981; Tolderlund e Bé, 1971), sabe-se que esta espécie pode habitar águas com uma grande amplitude de salinidades (Hilbrecht, 1996) e, como muitas vezes as baixas salinidades resultam da elevação de águas da termoclina ou de águas costeiras (ambas associadas ao aumento de produtividade), a correlação entre a abundância de $N$. dutertrei e a salinidade muito provavelmente seja causada pela resposta comum à presença de uma massa d'água mais fértil e menos salina. Isto reforça o fato da existência de correlação entre variáveis não ser sinônimo de causalidade.

A preferência por certa estabilidade da coluna d'água faz com que as condições ambientais ideais para $N$. dutertrei sejam um pouco diferentes das ideais para $G$. bulloides, outra espécie normalmente associada à produtividade. Além de poder se desenvolver bem em ambientes frios e pouco estáveis, por se tratar de uma espécie onívora, G. bulloides é menos dependente da abundância de fitoplâncton. O uso da 
razão entre as abundâncias relativas de G. bulloides e G. ruber (white) foi inicialmente proposto por Tolderlund e Bé (1971) para inferir mudanças passadas de gradientes térmicos. Posteriormente, foi utilizada por Conan et al. (2002) e Toledo et al. (2008) como indicadora de paleoprodutividade no segundo caso, em uma análise do testemunho SAN76. O uso da razão G. bulloides/G. ruber se justifica pelas preferências ecológicas opostas entre as espécies. G. ruber é a espécie dominante das assembléias de foraminíferos planctônicos nos trópicos e a sua abundância está diretamente relacionada à temperatura (Hilbrecht, 1996). A Tabela 4.2 apresenta resumidamente as diferentes preferências ecológicas das duas espécies.

Tabela 6.3. Relação das espécies G. bulloides e G.ruber com algumas variáveis ambientais e biológicas importantes, de acordo com Toledo et al., (2008).

\begin{tabular}{|c|c|c|c|c|}
\hline & & G. bulloides & G. ruber & Referências \\
\hline \multirow[t]{2}{*}{ Bióticos } & Simbiontes & Sem simbiontes & Com simbiontes & $\mathrm{a}, \mathrm{b}$ \\
\hline & $\begin{array}{l}\text { Atividade } \\
\text { trófica }\end{array}$ & $\begin{array}{l}\text { Onívora, mas } \\
\text { principalmente } \\
\text { herbívora }\end{array}$ & $\begin{array}{l}\text { Onívora com } \\
\text { preferência por uma } \\
\text { dieta carnívora }\end{array}$ & b \\
\hline \multirow[t]{3}{*}{ Abióticos } & $\begin{array}{l}\text { Temperatura } \\
\text { da água }\end{array}$ & $\begin{array}{l}\text { Presente sob um amplo } \\
\text { espectro de } \\
\text { temperaturas. } \\
\text { Geralmente é mais } \\
\text { abundante em } \\
\text { ambientes frios } \\
\text { subtropicais e } \\
\text { transicionais. }\end{array}$ & $\begin{array}{l}\text { A sua distribuição é } \\
\text { claramente } \\
\text { influenciada pela } \\
\text { temperatura da água. } \\
\text { Prefere águas cálidas. }\end{array}$ & $c, d$ \\
\hline & Produtividade & $\begin{array}{l}\text { Maiores abundâncias } \\
\text { ocorrem em águas } \\
\text { eutróficas com alta } \\
\text { produtividade } \\
\text { fitoplanctônica }\end{array}$ & $\begin{array}{l}\text { Espécie adaptada a } \\
\text { ambientes } \\
\text { oligotróficos. }\end{array}$ & $\mathrm{b}, \mathrm{e}, \mathrm{f}, \mathrm{g}$ \\
\hline & $\begin{array}{l}\text { Luz (ver } \\
\text { simbiontes) }\end{array}$ & $\begin{array}{l}\text { Por ser uma espécie } \\
\text { assimbiótica, não é } \\
\text { influenciada } \\
\text { significativamente pela } \\
\text { luz, portanto, esta } \\
\text { espécie pode habitar } \\
\text { águas mais turvas. }\end{array}$ & $\begin{array}{l}\text { A luz é necessária para } \\
\text { a fotossíntese dos } \\
\text { simbiontes. A } \\
\text { abundância aumenta } \\
\text { mar afora à medida } \\
\text { que a turbidez de água } \\
\text { diminui. }\end{array}$ & $\mathrm{g}, \mathrm{h}$ \\
\hline
\end{tabular}

Referencias: ${ }^{\mathrm{a}}$ Bé et al. (1977), ${ }^{\mathrm{b}}$ Hemleben et al. (1989), ${ }^{\mathrm{c}}$ Hilbrecht (1996), ${ }^{\mathrm{d}}$ Kemle-von Mücke e Hemleben (1999), ${ }^{\mathrm{e}}$ Sautter e Thunell (1991), ${ }^{\mathrm{f}}$ Watkins et al. $(1998),{ }^{\mathrm{g}}$ Ortiz et al. $(1995),{ }^{\mathrm{h}}$ Bé et al. (1985). 
Finalmente, devido à dependência dos organismos bentônicos ao aporte de alimento da superfície (Gooday, 2002), em geral, pode se esperar uma boa correlação entre o fluxo de matéria orgânica para o fundo do mar e a biomassa bentônica. Por este motivo, é possível considerar a abundância relativa de ostracodes e foraminíferos bentônicos como indicadora de paleoprodutividade. No entanto, outros fatores podem interferir na abundância.

No caso dos foraminíferos bentônicos, van der Zwaan et al. (1999) mostram que a abundância depende em grande parte do fluxo de matéria orgânica (aporte de alimento), mas somente enquanto o oxigênio não é um fator limitante. Além disso, como os foraminíferos planctônicos são organismos de oceano aberto e estão ausentes ou encontram-se pouco representados em águas costeiras e de plataforma, de um modo geral, a relação entre planctônicos e bentônicos também é reflexo do grau de influência do habitat oceânico versus marinho no momento da deposição (Hemleben et al., 1989). A abundância dos foraminíferos bentônicos geralmente atinge um máximo na plataforma externa e talude superior (van Hinsbergen et al., 2005). Por este motivo, a relação também é utilizada como indicador de paleoprofundidade. Por último, a proporção entre foraminíferos bentônicos e planctônicos também depende de processos de dissolução já que, por possuírem testas mais porosas destinadas à manutenção da flutuabilidade, os planctônicos são mais suscetíveis à dissolução do que os bentônicos (Berger, 1973; Malmgren, 1983).

Ao analisarmos as variações faunais, devem ser levadas em consideração duas limitações. Primeiro, o fato de possíveis defasagens temporais (sazonais) nas condições registradas por cada um dos indicadores, já que diferentes espécies costumam apresentar picos de abundância em diferentes momentos ao longo do ano (Hemleben et al., 1989). Em segundo lugar, por se tratar de dados de abundâncias relativas ao invés de dados de abundâncias absolutas, correlações entre curvas de abundância de duas espécies podem ser apenas um artefato resultante do aumento/ou diminuição de outra espécie importante. Um possível exemplo disto é o aumento da abundância relativa da variante pink de G. ruber em torno de 700 anos AP. Este aumento pode se dever à ocupação do nicho ecológico parcialmente liberado pelo morfotipo white ou pode ser simplesmente um aumento aparente da variante pink em resposta a uma diminuição da abundância do morfotipo white (Fig. 5.7). 
Além da composição de isótopos de carbono em $G$. ruber e dos indicadores faunais, são considerados nesta análise os dados de Bariani (2009) de teor de carbonato na fração fina (Fig. 5.17).

\subsubsection{Variações de paleoprodutividade}

Considerando que as variações de paleoprodutividade sugeridas pelos diferentes indicadores apontam para tendências distintas nos dois testemunhos, a análise é feita separadamente. As diferenças sugerem que as variações de produtividade nas regiões dos dois testemunhos estejam provavelmente relacionadas a diferentes mecanismos de fertilização.

\subsubsection{Testemunho KF02}

Exceto pelo registro de isótopos de carbono em G. ruber os demais indicadores apontam claramente para um período de máxima produtividade em torno de 14 mil anos (lembrando que o intervalo de tempo representado pelo testemunho é de 15,2 mil anos) (Figs. 5.16 e 5.30). De maneira geral, a produtividade teria sido maior durante a deglaciação e início do Holoceno até aproximadamente 8 mil anos AP. Os valores elevados do teor de carbonato na fração fina (Fig. 5.17) também sugerem uma maior produtividade aproximadamente neste período, mas somente até 9,7 mil anos AP.

Dada a maior produtividade, poderia se esperar maiores valores de $\delta^{13} \mathrm{C}$ em $G$. ruber para este período, entretanto, observou-se o contrário. Possíveis mecanismos para explicar os menores valores no período de maior produtividade incluem (a) a dominância do sinal global sobre o sinal local uma vez que o sinal global se caracteriza por menores valores no glacial (Shackleton, 1977) (b) a ressurgência de águas da termoclina onde o $\delta^{13} \mathrm{C}$ já foi remineralizado ou (c) o aporte de águas de origem continental com valores tipicamente mais baixos. Contudo, a defasagem dos sinais isotópicos em planctônicos e em rocha total (lembrando que os valores de rocha total constituem uma integração dos sinais planctônico e bentônico) parece contradizer a primeira alternativa (Fig. 6.9). 


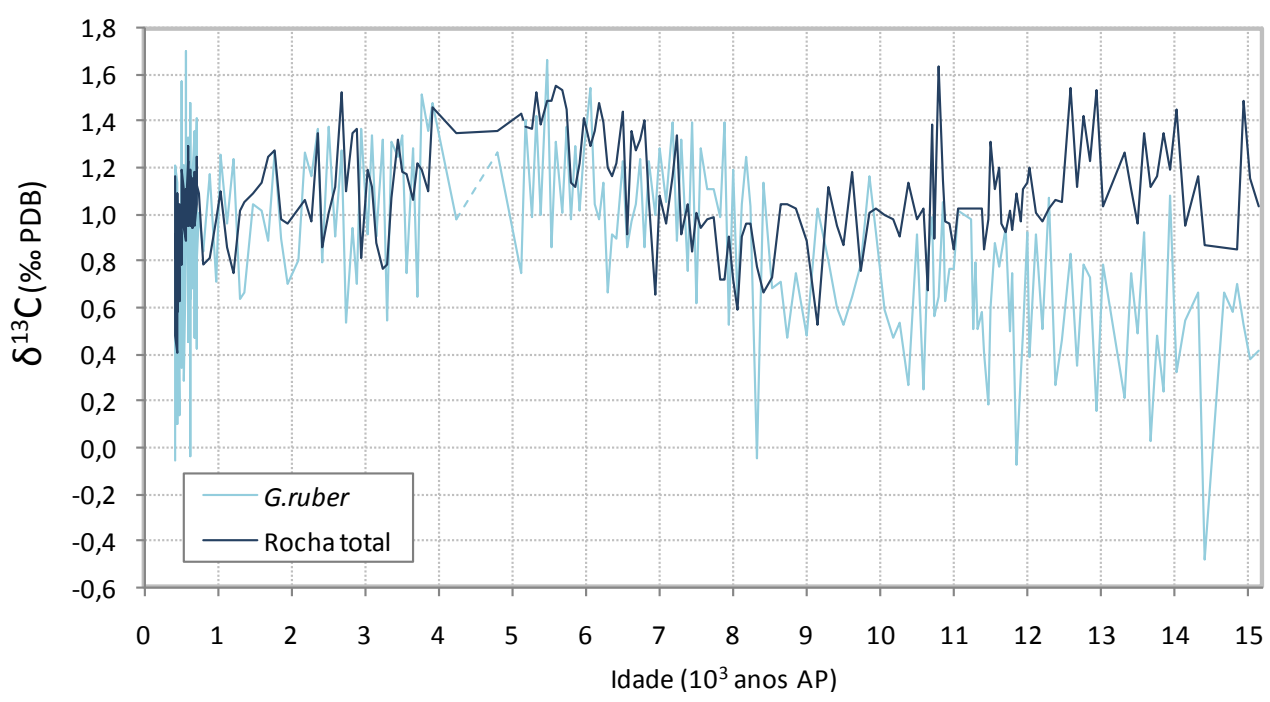

Fig. 6.9. Registro de isótopos de carbono em rocha total e em G. ruber no testemunho KF02.

De maneira geral a curva de $\delta^{13} \mathrm{C}$ em $G$. ruber e em rocha total são semelhantes exceto na base do testemunho, justamente no período para o qual se estima a maior produtividade. Esta diferença está evidentemente relacionada ao sinal de organismos bentônicos o qual é mais forte nesta seção do testemunho pela maior proporção de ostracodes e foraminíferos bentônicos (Fig. 5.30). Em condições normais, os valores de $\delta^{13} \mathrm{C}$ em planctônicos são maiores do que em bentônicos (ver exemplo da Fig. 6 10). A inversão poderia então ser atribuída à entrada de águas de origem continental as quais se caracterizam por baixos valores de $\delta^{13} \mathrm{C}$.

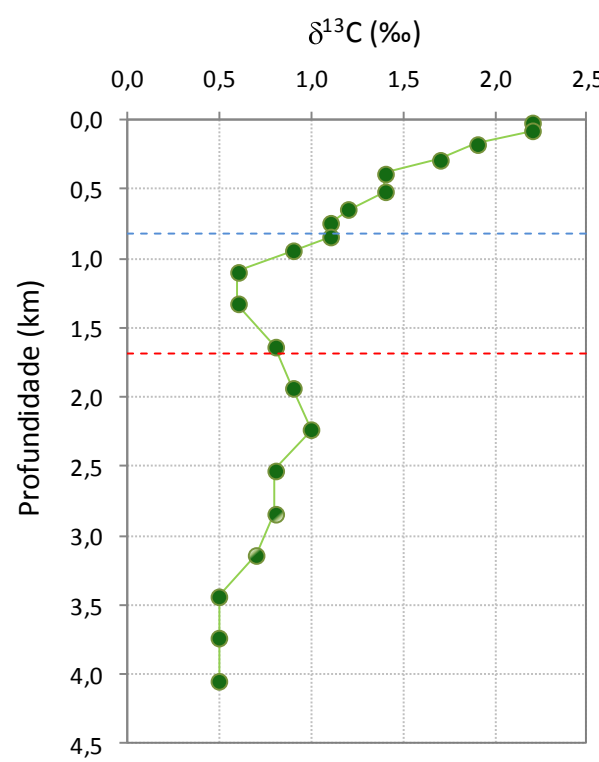

Fig. 6.10. Variação de $\delta^{13} \mathrm{C}$ da água do mar em função da profundidade na estação do GEOSECS mais próxima à área de estudo (estação $57 ; 23,98^{\circ} \mathrm{S} ; 35,02^{\circ} \mathrm{W}$ ) (Östlund et al., 1987). As linhas pontilhadas azul e vermelha indicam respectivamente as profundidades de coleta dos testemunhos KF02 e SAN76. 
No entanto, embora o máximo de paleoprodutividade estimado em torno de 14 mil anos coincida com valores elevados das razões $\mathrm{Ti} / \mathrm{Ca}$ e $\mathrm{Fe} / \mathrm{Ca}$, o período de maior produtividade parece se estender até 8 mil anos, coincidindo com as mínimas razões $\mathrm{Ti} / \mathrm{Ca}$ e $\mathrm{Fe} / \mathrm{Ca}$ as quais sugerem um mínimo de aporte continental. Por outra parte, entre 14 e 10 mil anos AP, os teores de carbonato são mais elevados (Fig. 5.17) o que pode justificar parcialmente as baixas razões $\mathrm{Ti} / \mathrm{Ca}$ e Fe/Ca. Este argumento, no entanto, não é totalmente satisfatório primeiro pelo fato das taxas de sedimentação não terem se mantido elevadas durante o período (Fig. 6.1). Se a redução das razões tivesse sido causada por um aumento do $\mathrm{Ca}$, se esperaria maiores valores de taxa de sedimentação, entretanto, os valores elevados ocorreram apenas de 12 a 10,5 mil anos AP aproximadamente. Em segundo lugar, a ótima correlação das razões Ti/Ca e Fe/Ca com a insolação sugere que estas realmente sejam um reflexo do aporte continental, pouco influenciado pelas variações no teor de carbonato.

Isto significa que provavelmente o início do período identificado como mais produtivo esteja relacionado ao aporte de águas continentais, possivelmente do Rio da Prata. Já no restante do período, coincidente com baixas razões Ti/Ca e $\mathrm{Fe} / \mathrm{Ca}$, a fertilização estaria associada a um aumento da ressurgência. Cabe ressaltar que este segundo período coincide com um período de maior produtividade no testemunho SAN76 (seção 6.3.2.2).

Além da importância da precipitação sobre a influência de águas da drenagem continental na área de estudo, devem ser considerados os ventos. Estudos observacionais (Piola et al., 2005) e de modelagem (Pimenta et al., 2005) demonstram que o grau de penetração da pluma do Rio da Prata para o norte depende muito mais da atuação de ventos favoráveis (de SW) do que da vazão do rio. Por outro lado, a ressurgência costeira na área de estudo é favorecida pela ação de ventos de NE (Castro e Miranda, 1998). Desta forma, dados paleoclimáticos que permitam fazer inferências sobre mudanças no padrão de ventos são essenciais para elaborar uma reconstrução mais precisa e identificar melhor os mecanismos de fertilização na área de estudo.

Por outra parte, ao analisar os possíveis aportes continentais, devem ser consideradas as mudanças na configuração das desembocaduras em função de variações do nível do mar. No caso do Rio da Prata, sabe-se que a configuração da desembocadura mudou significativamente ao longo do período estudado (por ex. Violante e Parker, 2004; Laprida et al., 2007). Além disso, embora a pluma do Rio da 
Prata hoje se estenda sobre a plataforma continental, isto deveria ser diferente em condições de nível do mar mais baixo e de uma plataforma mais estreita. Já no caso dos rios da região de estudo, embora as dimensões das bacias de drenagem sejam reduzidas, em condições do nível do mar mais baixo, o local do testemunho KF02 poderia sofrer uma influência mais direta desta drenagem, principalmente dos rios Ribeira de Iguape e Itanhaém, como sugerem os paleocanais que atravessam a plataforma continental da área de estudo identificados por Conti e Furtado (2005, 2009).

É interessante notar que os máximos de abundância de G. truncatulinoides (dex) coincidem com valores relativamente elevados de salinidade (e mínimo de precipitação de monção de acordo com o exposto na seção 6.2.2). Isto é o esperado já que tais condições favorecem uma menor estratificação da coluna d'água, proporcionando condições ideais para o desenvolvimento da espécie. No entanto, um aumento da pluma do Rio da Prata favoreceria a estratificação da coluna d'água. Uma possível explicação para esta divergência seria o registro de épocas diferentes do ano por parte dos diferentes indicadores (por ex. entrada da Pluma do Rio da Prata em uma época do ano e picos de abundância de G. truncatulinoides em outro). O fato das estimativas de amplitude térmica (TSM de verão - TSM de inverno) apontarem para maiores valores no período entre 12 e 14,5 mil anos AP (Fig. 5.14) pode ser um indício da influência de águas do Rio da Prata (mais frias) durante o inverno neste período.

Além do período de maior produtividade na deglaciação e início do Holoceno, alguns indicadores sugerem uma tendência a um novo aumento de produtividade no final do registro, embora muito menos significativo do que o período já descrito. Este aumento de produtividade nos últimos mil anos coincide parcialmente com as maiores taxas de sedimentação (Fig. 5.4) e com um importante aumento no aporte de sedimentos terrígenos tal como sugerido pelas razões Ti/Ca e Fe/Ca (Fig. 5.17). Já o teor de carbonato na fração fina (Fig. 5.17) também sugere um aumento de produtividade no final do Holoceno, mas iniciando antes, em torno de 3 mil anos AP.

Mahiques et al. (2009) detectaram um padrão semelhante de aumento da produtividade em direção ao recente iniciando em torno de 3 mil anos AP. O testemunho analisado por Mahiques et al. (2009) foi coletado mais ao sul (2659'16,8'S; 48 4'33,6”'W) em uma profundidade de $60 \mathrm{~m}$. Tal aumento da produtividade foi interpretado pelos autores como consequiência de um aumento da influência de águas de drenagem do Rio da Prata. Considerando que, assim como no caso do testemunho KF02, o modelo de idade do testemunho analisado por Mahiques et 
al. se sustenta em um número significativo de datações, então pode se interpretar os resultados como o reflexo de um progressivo aumento da influência do deságüe do Rio da Prata em direção ao norte no final do Holoceno.

\subsubsection{Testemunho SAN76}

Embora exista menos concordância no registro dos diferentes indicadores no testemunho SAN76 a razão $G$. bulloides/G. ruber e a abundância relativa de foraminíferos bentônicos sugerem que o período mais produtivo na área deste testemunho tenha ocorrido no UMG, com um máximo em torno de 19 mil anos AP. Os resultados estão de acordo com estimativas de Mahiques et al. (2007) de uma maior produtividade na área de estudo durante o UMG.

Este período coincide com valores de paleossalinidade relativamente baixos (Fig. 5.29). Esta coincidência faz sentido se lembrarmos que a fertilização na área de estudo pode estar associada à entrada da ACAS ou de AC, ambas as massas d'água caracterizadas por menores valores de paleossalinidade (Fig. 2.9). No entanto, de acordo com o analisado na seção 6.2.2 (Fig. 6.8) as menores salinidades neste período provavelmente estejam relacionadas a um aumento da precipitação de monção.

A baixa abundância relativa de G. truncatulinoides (dex) no final do UMG pode ser conseqüência de uma maior estratificação da coluna d'água. Se bem isto pode ser interpretado como uma evidência de que a ressurgência não foi importante neste período, não se pode descartar a possibilidade de uma defasagem entre os sinais de cada indicador. Por exemplo, a maior produtividade sugerida pela razão G. bulloides/G. ruber poderia refletir condições de ressurgência de verão enquanto na primavera (época em que G. truncatulinoides ascende na coluna d'água para completar o seu ciclo reprodutivo) condições mais estáveis com uma coluna d'água mais estratificada impediriam o desenvolvimento da espécie.

Entre 12 e 8 mil anos AP, se observa um aumento da abundância de $N$. dutertrei e maiores valores da razão $G$. bulloides/G. ruber o que sugere um novo período de produtividade intensificada. No final desse período ocorre o pico de maior abundância de G. truncatulinoides (dex) ao longo do testemunho SAN76. Conforme observado por Toledo et al. (2007b), existe uma boa correlação entre as estimativas de paleossalinidade e a abundância relativa de G. truncatulinoides (dex), sugerindo que o 
aumento da salinidade e conseqüente aumento da densidade das águas superficiais permite uma maior mistura vertical e favorece o ciclo reprodutivo da espécie. Já no caso de $N$. dutertrei a maior abundância no período de maior salinidade é mais uma evidência da falta de preferência desta espécie por águas menos salinas ao contrário do sugerido por alguns autores (ver seção 6.3.1).

Por outra parte, assim como no testemunho KF02, o registro de isótopos de carbono em G. ruber mostra um comportamento diferente do esperado, com os valores mínimos coincidindo com um período de produtividade elevada, entre 12 e 10 mil anos AP. Este mínimo de $\delta^{13} \mathrm{C}$ poderia ser conseqüência de um aumento da influência de água costeira ou da elevação da ACAS. Devido à maior distância da desembocadura do Rio da Prata pode se esperar uma menor influência, no entanto, esta possibilidade não pode ser totalmente descartada uma vez que o nível do mar era significativamente mais baixo e a configuração da plataforma continental era muito diferente da atual no período de maior produtividade. Entretanto, os valores elevados de salinidade somados a coincidência com um período de alta produtividade atribuída à ressurgência na área do testemunho KF02 parecem excluir a hipótese da presença de águas de origem continental e reforçam a hipótese de uma elevação da ACAS.

Por último, é interessante notar que o período de produtividade relativamente elevada identificado no testemunho SAN76 entre 12 e 8 mil anos AP coincide parcialmente com um período de abundâncias relativamente elevadas de $G$. truncatulinoides (dex) e N. dutertrei no testemunho KF02.

\subsection{AS VARIAÇÕES DE PALEOTEMPERATURA E PALEOSSALINIDADE NO CONTEXTO REGIONAL E GLOBAL}

A Fig. 6.11 apresenta um resumo dos resultados obtidos para os dois testemunhos analisados. De maneira geral, considerando as limitações dos modelos de idade e o maior espaçamento entre amostras no testemunho SAN76, se observa uma boa concordância no período em comum entre ambos. Nos dois registros se observa uma tendência semelhante de variação de paleotemperaturas e paleossalinidades até aproximadamente 8 mil anos AP, momento a partir do qual as temperaturas se elevam e os valores de paleossalinidade diminuem. 

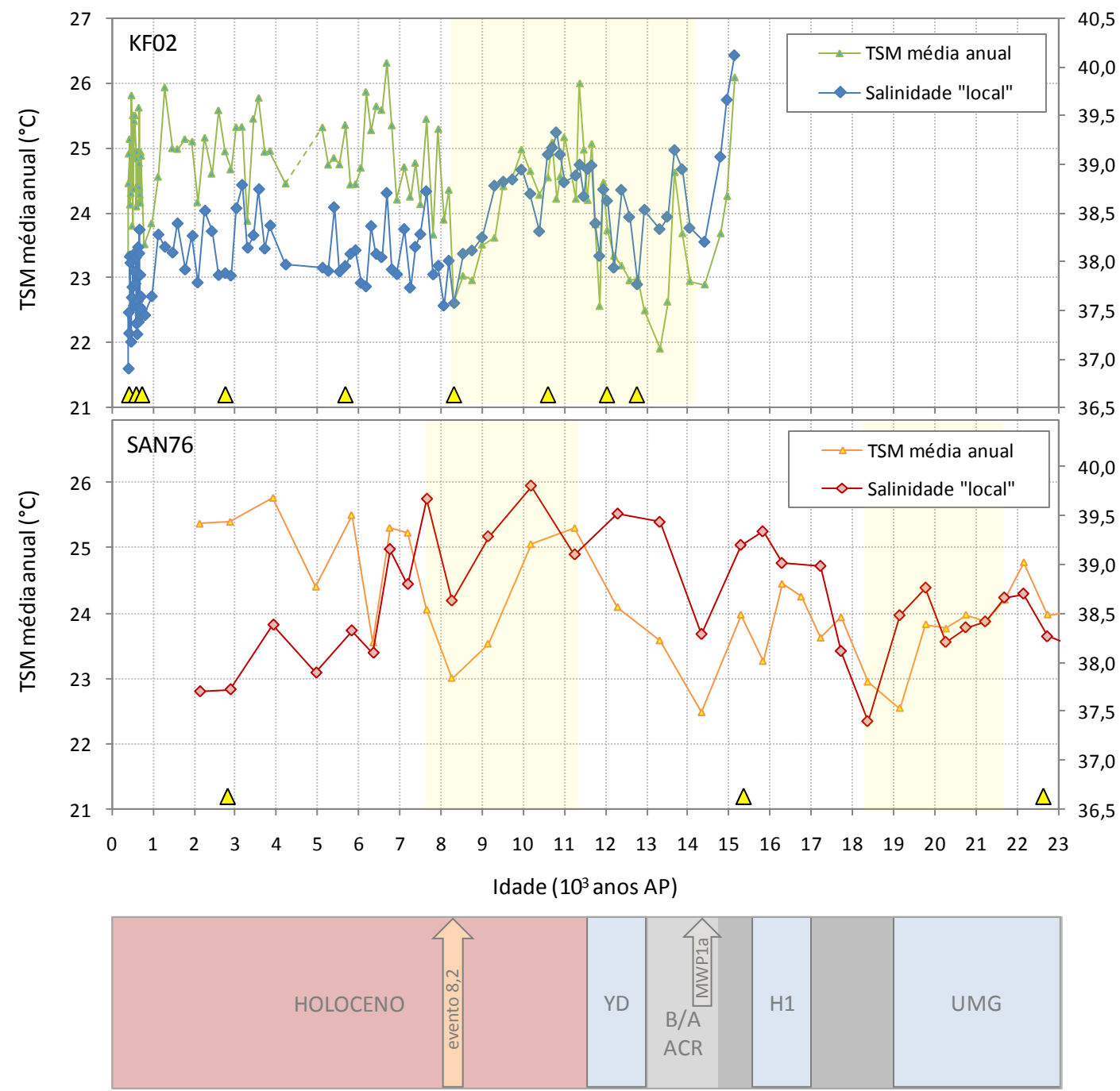

Fig. 6.11. Estimativas de paleotemperatura média anual e paleossalinidade para os testemunhos KF02 (gráfico superior) e SAN76 (gráfico inferior). Os triângulos amarelos indicam as amostras datadas por ${ }^{14} \mathrm{C}$. As seções sombreadas indicam os períodos para os quais foram estimadas as maiores paleoprodutividades. A parte inferior da figura inclui a seqüência de eventos (globais ou não) ocorridos durante o período analisado (ver capítulo 3). Legenda: YD = Younger Dryas, $\mathrm{B} / \mathrm{A}=$ Bolling Allerod, ACR = Reversão Fria Antártica, MWP1a = Pulso de degelo 1a, H1 = evento Heinrich $1, \mathrm{UMG}=$ Último Máximo Glacial.

Para compreender a relação dos registros analisados com os eventos de grande escala, é necessário considerar as variações na circulação termohalina. Diversos trabalhos têm demonstrado a relação entre a exportação de calor e sal para o hemisfério Norte e a intensidade da célula de transporte meridional (MOC). Em períodos de enfraquecimento da MOC, a exportação de calor e sal para o hemisfério Norte teria diminuído, ocorrendo um acúmulo destes no Atlântico Sul (Manabe e Stouffer, 1997; Rühlemann et al., 1999). Entretanto, de acordo com o estudo de modelagem de Dahl et al. (2005), o acúmulo de calor não seria tão evidente quanto o acúmulo de sal, uma vez 
que as trocas oceano-atmosfera se encarregariam de dissipar parte deste calor da superfície.

Outro fator fundamental a ser considerado são as variações na circulação atmosférica. Carton et al., 1996, demonstraram que as variações de TSM no Atlântico Tropical são controladas pelos ventos alísios de NE e SE os quais afetam as correntes e contracorrentes equatoriais e, desta forma, as correntes que elas alimentam. Por sua vez, variações de TSMs estão diretamente relacionadas a variações de precipitação (Diaz et al., 1998; Robertson e Mechoso, 2000) as quais também influenciam a SSM.

Comparando as variações registradas nos testemunhos KF02 e SAN76 com os eventos ocorridos no período (Fig. 6.11) se observa que, parte das variações de paleotemperatura e paleossalinidade registradas podem ser explicadas no contexto das variações da intensidade da MOC. Por exemplo, o significativo enfraquecimento da MOC durante o evento H1 (McManus et al., 2004; Gherardi et al., 2005; 2009), justifica o aquecimento e aumento de salinidade na área de estudo, assim como durante o YD. O aquecimento e aumento de salinidade não teriam se limitado ao Atlântico Sul, mas a todo o Atlântico Tropical ocidental como demonstram os registros de Arz et al. (1999) e Weldeab et al. (2006) para a margem continental nordeste do Brasil.

No caso do UMG, os trabalhos mais recentes indicam que a MOC teria se mantido intensa, no entanto, com uma configuração diferente (Gherardi et al., 2009). Durante períodos de resfriamento no hemisfério Norte como o UMG, a ZCIT teria se deslocado para o sul provocando mudanças nos ventos alísios de maneira análoga ao deslocamento sazonal da ZCIT na direção do hemisfério mais aquecido (Broccoli et al., 2006). Uma posição mais meridional da ZCIT estaria associada a um fortalecimento tanto dos alísios de NE como da CB o que está de acordo com a manutenção de valores elevados de TSM e SSM resultantes de uma redução do fluxo de calor através do equador (seção 2.3.3).

Embora os valores estimados de paleossalinidade para o UMG sejam relativamente elevados em comparação aos valores do Holoceno médio em diante, eles são menores do que na deglaciação o que, de acordo com o exposto anteriormente na seção 6.2.2 poderia estar relacionado a um fortalecimento do SMAS e da atividade da SACZ.

Se as variações de TSM e SSM na área de estudo forem atribuídas a variações nos fluxos através do equador, os mínimos de paleotemperatura e paleossalinidade em torno de 19 mil anos AP podem ser interpretados como o resultado de um 
restabelecimento de um fluxo intenso de calor e sal para o Atlântico Norte no final do UMG. É interessante notar que o mínimo em torno de 19 mil anos se assemelha aos mínimos em torno de 14,5 e 8,2 mil anos AP. Os três momentos coincidem respectivamente com (1) o primeiro pulso de degelo após o UMG (Clark et al., 2004), (2) o pulso de degelo MWP1a e (3) o evento de 8,2 mil anos AP, o qual também é atribuído a um grande pulso de degelo (Renssen et al., 2002). Por serem responsáveis pela introdução de grandes volumes de água doce no oceano, os pulsos de degelo determinam importantes mudanças na circulação.

Analisando a Fig. 6.12 (b), se observa que os eventos associados aos pulsos de degelo se destacam na curva de estimativas de composição isotópica da água do mar para o testemunho SAN76 e são os principais desvios do padrão de variação esperado de acordo com as variações da insolação. Na Fig. 6.12(a) se observa que tais eventos também são caracterizados por um maior contraste sazonal, de acordo com as estimativas de paleotemperaturas de verão e inverno. Já no caso do testemunho KF02 (Fig. 6.12c e d), os principais desvios em relação à curva de insolação são coincidentes com o evento de 8,2 mil anos AP e o YD, eventos para os quais também se verifica um aumento do contraste sazonal.

Infelizmente o maior espaçamento entre amostras no testemunho SAN76 e a menor resolução do modelo de idade limitam a interpretação, no entanto, se assumirmos que a curva é representativa das variações ocorridas no período, os resultados do testemunho SAN76 sugerem condições distintas no YD em ambos os testemunhos. Enquanto no caso do testemunho SAN76, o período do YD não se caracteriza por variações bruscas nem um contraste sazonal intenso, no testemunho KF02, o YD apresenta um desvio importante em relação ao padrão esperado de acordo com as mudanças de insolação (Fig. 6.12d).

$\mathrm{O}$ aquecimento e aumento da salinidade durante o YD eram esperados por se tratar de um breve retorno às condições glaciais no hemisfério Norte com um provável deslocamento para sul da ZCIT. É importante observar que, de acordo com os dados dos dois testemunhos, o início do YD em 13 mil anos AP teria sido marcado por um aumento de salinidade maior que o aumento de paleotemperatura. Isto pode ser explicado pela coincidência com um mínimo de insolação o que teria diminuído a precipitação. Outra possível explicação seria a atenuação das variações de paleotemperatura superficial devido às trocas com a atmosfera, resultando em um aumento da salinidade maior do que o de temperatura (Dahl et al., 2005). 
(a)

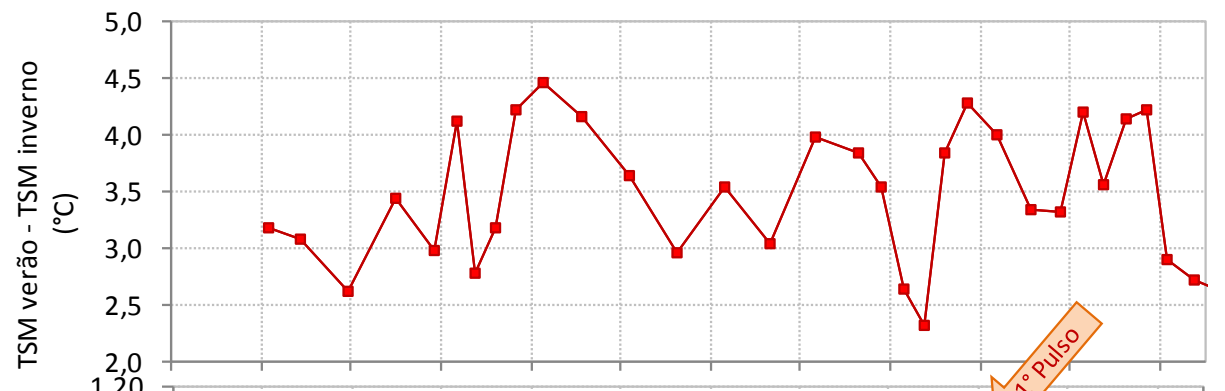

(b)

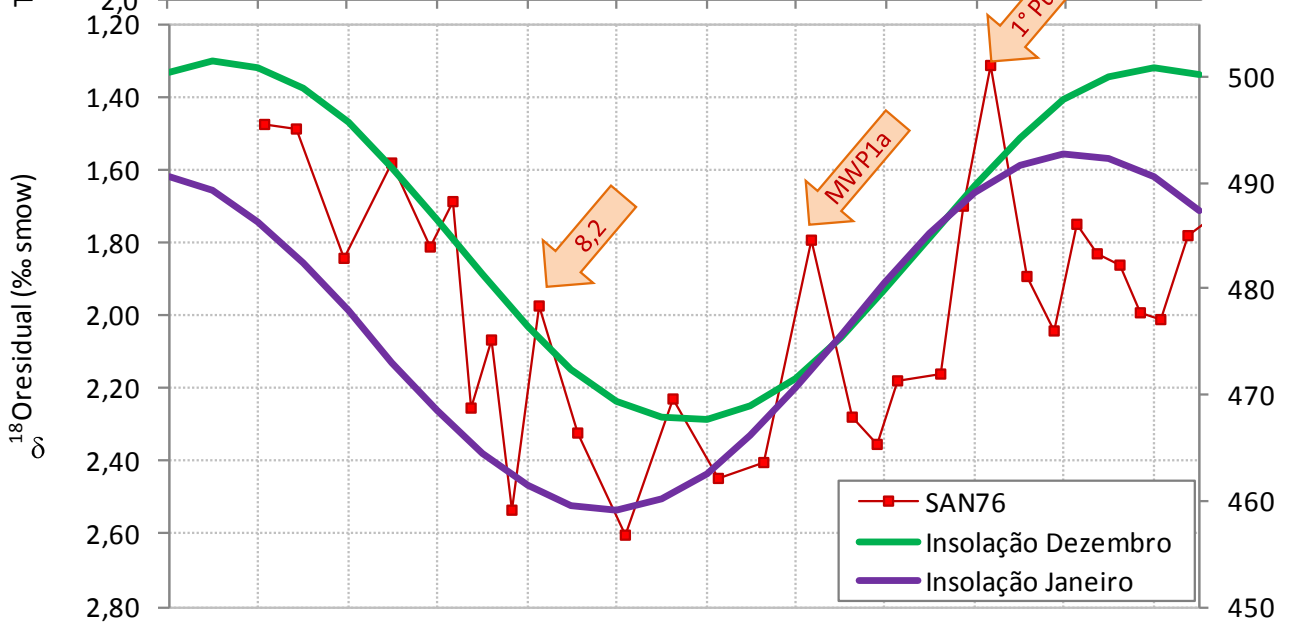

(c)

(d)
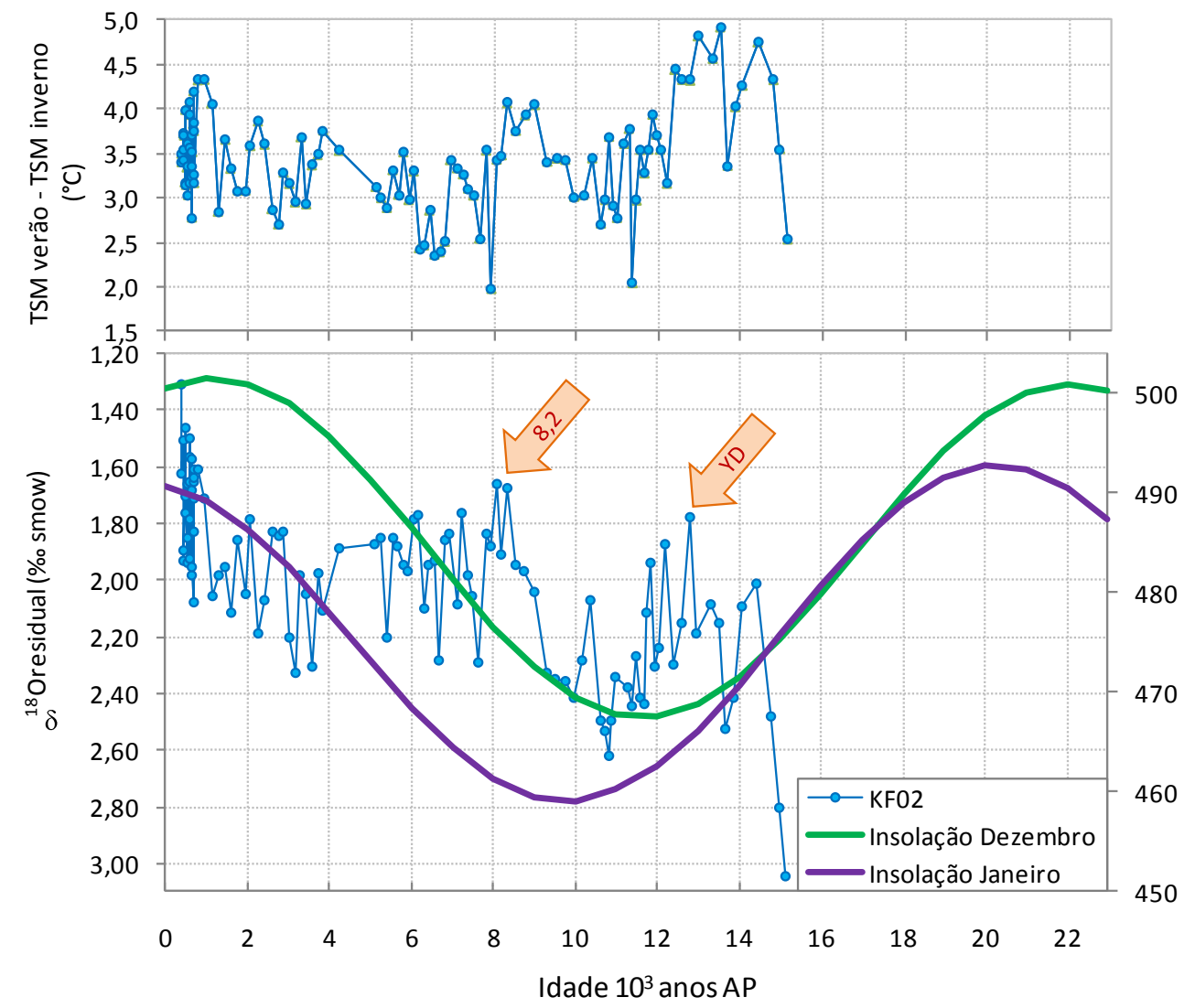

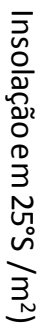

Fig. 6.12. Comparação das estimativas de composição isotópica da água do mar (após extração do efeito do volume de gelo) e as curvas de insolação de verão para $25^{\circ} \mathrm{S}$ com o contraste sazonal definido como a diferença entre as temperaturas de verão e inverno. Estão destacados os eventos de degelo de $\sim 19$ mil anos, 14 mil anos (MWP1a) e 8,2 mil anos AP, assim como o período correspondente ao evento $\mathrm{YD}$, no testemunho KF02. 
Em relação ao período B/A, embora tenha sido um período quente no hemisfério Norte, a circulação era muito diferente da circulação durante o Holoceno, com características intermediárias entre as do UMG e o evento H1 (Gherardi et al., 2009). As causas responsáveis pelo aquecimento não estão bem esclarecidas tendo sido atribuídas ao pulso de degelo MWP1a (Weaver et al., 2003) e a um fortalecimento do vazamento de anéis da Corrente das Agulhas (Chiessi et al., 2008). Para este período, Kim e Schneider (2003) apresentam evidências de um enfraquecimento dos ventos alísios de SE o que levaria a um enfraquecimento da ressurgência no Atlântico Sul oriental, diminuindo a assimetria E-W de TSMs e profundidade de termoclina. Isto fica bem claro na comparação dos registros desta tese com as estimativas de paleotemperatura de Farmer et al. (2005) para a região de Benguela (Fig. 6.13). A mesma Figura evidencia a diferença entre o B/A e o Holoceno em termos de contraste de TSM superficial.

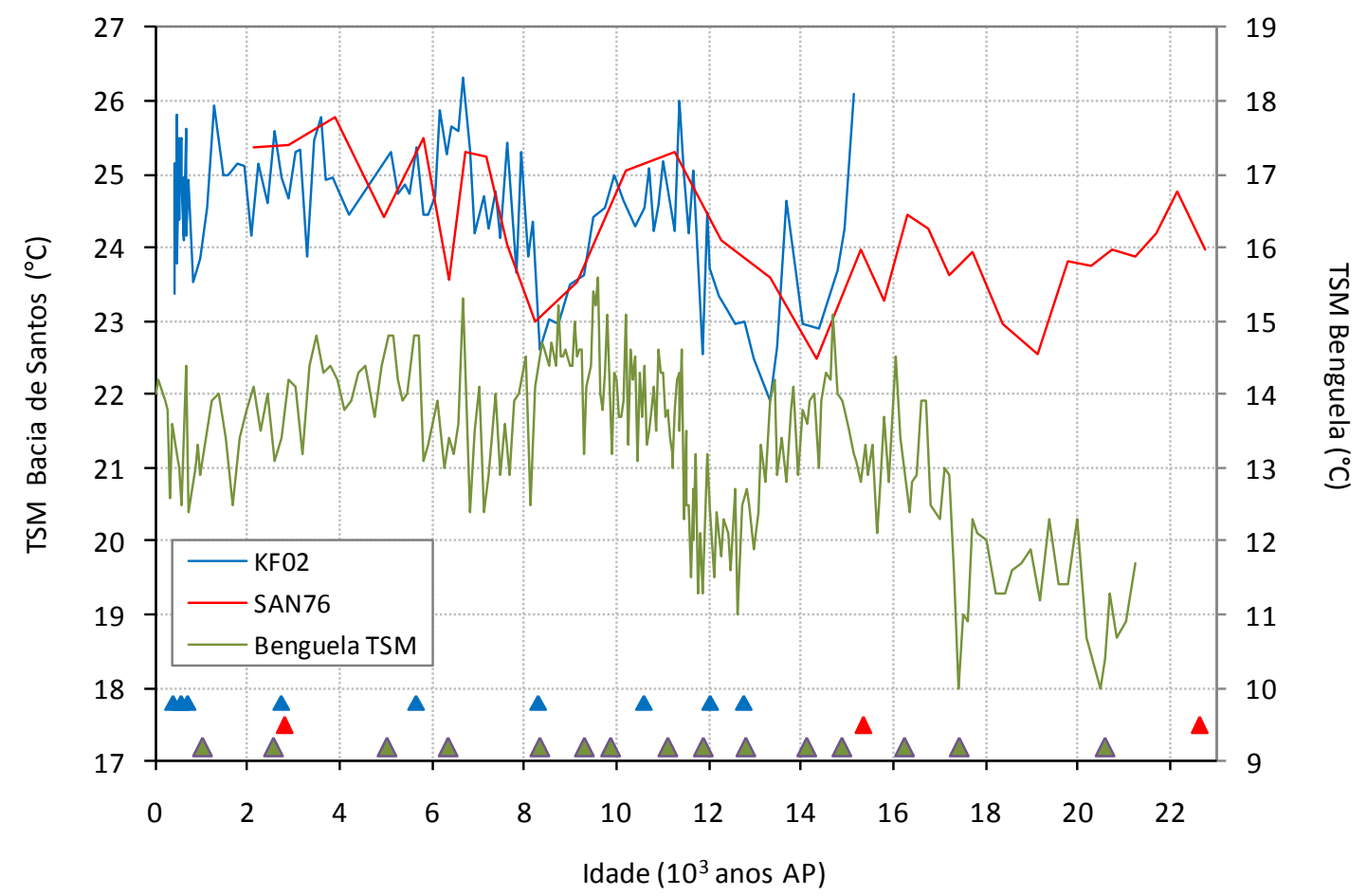

Fig. 6.13. Comparação das estimativas de paleotemperatura superficial na região de estudo e na região de Benguela de acordo com dados de Farmer et al. (2005). Os dados de Farmer et al. se baseiam em medidas da razão $\mathrm{Mg} / \mathrm{Ca}$ em testas de G.bulloides. Os triângulos indicam as datações e estão sinalizados de acordo com a cor da respectiva curva. 
Na Fig. 6.13 se observa também a forte assimetria E-W de TSMs identificada no Projeto MARGO (2009) para o UMG devido à manutenção de TSMs relativamente elevadas na margem ocidental e a um resfriamento intenso na margem oriental. Este resfriamento pode estar relacionado a uma maior ressurgência e/ou a advecção de águas subpolares para a Corrente de Benguela (Kucera et al., 2005).

Outro período de reduzido contraste E-W em termos de TSMs no Atlântico Sul corresponde ao evento de 8,2 mil anos AP. Antes deste evento, o início do Holoceno teria sido marcado por um período de temperaturas e salinidades em declínio na área de estudo, enquanto o Atlântico Sul oriental teria passado por um período de aquecimento, provavelmente associado a um gradual enfraquecimento dos ventos alísios de SE (Kim e Schneider, 2003). O resultado é uma tendência a um menor contraste E-W durante o início do Holoceno (Fig. 6.13).

O limite entre as condições deglaciais e as condições tipicamente Holocênicas é marcado pelo evento de 8,2 mil anos AP. A transição se caracterizou por importantes mudanças na composição da fauna com o aumento da abundância das espécies do Plexo menardiforme e G. calida e o desaparecimento ou significativa redução das abundâncias de G. inflata, N. pachyderma e G. crassaformis, além da redução drástica de $N$. dutertrei e G. truncatulinoides (dex) o que também caracterizaria o início de um período de menor produtividade.

Uma observação interessante é o fato das estimativas de paleotemperatura e paleossalinidade coincidirem de forma clara ao longo de cada testemunho e entre testemunhos, mas somente até o evento de 8,2 mil anos. No testemunho SAN76, após o evento de 8,2 mil anos se observa uma tendência ao aquecimento e redução da salinidade. Parte desta redução de salinidade pode estar relacionada ao aumento da precipitação de monção, conforme analisado anteriormente. Já no testemunho KF02, a tendência à redução dos valores de paleossalinidade se verifica no final do registro (já fora do período registrado pelo testemunho SAN76).

Devido à progressiva migração para o sul da ZCIT desde o Holoceno Médio (Haug et al., 2001) poderia se esperar um aumento de paleotemperatura e paleossalinidade no período. Entretanto, observou-se o contrário. Por um lado, a diminuição da salinidade do Holoceno médio em diante pode ser explicada pelo aumento da precipitação associada ao SMAS. Por outro lado, a tendência à diminuição da paleotemperatura (principalmente de inverno; Fig. 5.27) provavelmente esteja relacionada ao aumento da freqüência de eventos El Niño no período (Tudhope et al., 
2001, Moy et al., 2002, Cane, 2005), uma vez que atualmente se observa uma relação entre anomalias negativas de TSM e a fase quente do ENOS (Lentini et al., 2001).

\subsubsection{Variações do SMAS}

Através de estudos de modelagem, Valdes e Glover (1999) demonstraram que a resposta tropical à forçante orbital (associada predominantemente ao sinal da precessão) está principalmente relacionada a variações no ciclo hidrológico. Esta observação, somada à significativa correlação entre as estimativas de composição isotópica da água residual e a insolação sugere que variações no SMAS teriam agido como importantes moduladores das variações paleoceanográficas na região de estudo. Por este motivo, os resultados foram comparados a outros trabalhos que analisam a intensidade do sistema de monção e as variações no regime hidrológico. De acordo com os resultados desta tese, a intensidade do SMAS teria sido proporcional às variações na insolação de verão na área da ZCAS (Figs. 6.8 e 6.12), com máximos na atualidade e no UMG e um mínimo em torno de 10 mil anos AP. Os máximos estariam caracterizados por períodos mais úmidos.

Os registros de isótopos de oxigênio em espeleotemas no sudeste do Brasil concordam em um controle dominante da insolação de verão sobre as mudanças sazonais de longo prazo (Cruz et al., 2005a, 2006). Uma exceção a este padrão ocorreu durante o evento de 8,2 mil anos AP. De acordo com o trabalho de Cheng et al. (2009), este evento teria se caracterizado por uma rápida intensificação do SMAS. Os mesmos autores identificaram um enfraquecimento simultâneo do Monção da Ásia neste período o que dá suporte à idéia do evento ter tido repercussão global. Embora a resolução dos espeleotemas seja muito melhor do que a dos testemunhos aqui analisados (principalmente no caso do testemunho SAN76) se observa que aproximadamente neste período ocorreu uma significativa redução da temperatura e salinidade na área de estudo evidenciada nos dois testemunhos analisados (Fig. 6.11). Os dados do testemunho KF02 para este evento são particularmente confiáveis pela existência de uma datação desta idade. A semelhança do evento de 8,2 mil anos com os eventos de degelo de 19 mil anos e o MWP1a (Fig. 6.12b) levantam a hipótese de ter ocorrido uma intensificação do SMAS também durante estes eventos.

Comparando com estudos palinológicos, trabalhos desenvolvidos no sudeste do Brasil por Behling (2002) e Behling et al. (2007) concordam em um Holoceno inferior 
mais seco e um Holoceno superior mais úmido. No entanto, para o UMG os diferentes estudos apresentam resultados distintos. Por exemplo, enquanto Pessenda et al. (2009) apresentam evidências de condições úmidas durante o UMG na região da Mata Atlântica, Behling et al. (2002) afirmam que o UMG teria se caracterizado por condições frias e áridas, o que teria provocado uma máxima expansão da vegetação de pradarias e uma redução da mata atlântica e da floresta semidecidual. Por um lado, a discordância entre os dados palinológicos e os desta tese podem ser parcialmente atribuídos ao fato do registro de isótopos de oxigênio refletir condições de verão (Wang et al., 1995) enquanto o registro palinológico representa uma integração das variações anuais. Isto é relevante devido à suscetibilidade da vegetação a mudanças na sazonalidade da precipitação. Por exemplo, Bush et al. (2004) demonstraram em um estudo no noroeste da Amazônia que a floresta pode ser relativamente resistente a mudanças de precipitação da estação úmida, más é muito suscetível a mudanças de precipitação da estação seca. Por outro lado, a discordância pode estar relacionada à falta de análogos modernos para os dados de pólen devido às variações na concentração do $\mathrm{CO}_{2}$ atmosférico (ver seção 3.1).

Diversos autores analisaram as variações hídricas ocorridas no Altiplano Sul Americano onde a precipitação também depende da intensidade do SMAS. Apesar de estar mais próximo do Oceano Pacífico, a principal fonte de vapor d'água para o setor norte do Altiplano é a Bacia Amazônica ao norte e ao leste (Cross et al., 2001). Trabalhos de Baker et al. (2001a,b), Paduano et al.(2003) e Tapia et al. (2003) nesta região além de um estudo de modelagem (Cross et al., 2001) concordam em um controle do SMAS sobre a precipitação em função de variações na insolação de verão. O máximo de insolação no hemisfério sul durante o UMG teria induzido um máximo de precipitação resultando em um aprofundamento e leve expansão do lago Titicaca (Baker et al., 2001a; Wirrmann e Mourguiart, 1995). Mais ao sul, no Altiplano Boliviano, teria existido um lago de grandes dimensões onde hoje se encontra o Salar de Uyuni (Baker et al., 2001b) o que sugere que, apesar das semelhanças em termos de intensidade de insolação, as condições no UMG teriam sido mais úmidas do que no final do Holoceno, ou então, que a precipitação de monção teria se estendido mais ao sul durante o UMG.

Ainda de acordo com os trabalhos do Altiplano, o início do Holoceno e o Holoceno médio teriam sido caracterizados como um período seco coincidente com a diminuição da insolação. Para este período, Rowe et al.(2003), estimaram um rebaixamento do nível do lago Titicaca de $85 \mathrm{~m}$. O máximo na frequiência de incêndios 
teria ocorrido em torno de 5.5 mil anos AP coincidindo com os níveis mais baixos do lago (Paduano et al., 2003; Baker et al., 2001b). Finalmente, o SMAS parece ter iniciado o seu novo fortalecimento entre 5 e 6 mil anos AP (Rowe et al., 2003) e após 4 mil anos AP, a precipitação já teria preenchido novamente a bacia do Titicaca e as condições atuais de extravasamento teriam se restabelecido (Tapia et al., 2003).

Como era esperado, o padrão detectado é oposto ao documentado para a Monção do Norte da África onde o início do Holoceno se caracterizou por uma fase úmida conhecida como o Período Úmido Africano (Roberts, 1998) (seção 3.3.1). Da mesma maneira, condições mais úmidas do que as atuais durante o início do Holoceno no SW da América do Norte (por ex. Bird e Kirby, 2006; Kirby et al., 2007) e na China (por ex.. An et al., 2000) foram relacionadas a um fortalecimento dos sistemas de monção da América do Norte e da Ásia.

Apesar de existir, no geral, uma boa concordância entre o fortalecimento/enfraquecimento dos sistemas de monção de hemisférios opostos, a correlação não é perfeita, já que, tal como demonstrado por dados paleoclimáticos e estudos de modelagem, a resposta dos sistemas de monção à insolação não é linear e difere significativamente de uma região a outra devido a processos de feedback relacionados à cobertura vegetal, TSMs e disponiblidade de vapor d'água (Kutzbach e Guetter, 1986; Kutzbach et al., 1996; Kutzbach e Liu, 1997; Claussen et al., 1999; deMenocal et al., 2000; Carrington et al., 2001; Liu et al., 2004). Estes feedbacks podem amplificar ou atenuar significativamente a forçante inicial de insolação. A intensa variabilidade espacial associada ao SMAS determina que, enquanto a intensificação do sistema pode ficar registrada em uma determinada região como um aumento de precipitação, em outros locais pode causar um aumento da aridez (Vuille e Werner, 2005). 


\section{CONCLUSÕES}

Variações da composição da fauna de foraminíferos planctônicos e da composição de isótopos de oxigênio e carbono em G. ruber em dois testemunhos coletados na margem ocidental do Atlântico Sul tropical revelaram a ocorrência de mudanças significativas nas condições oceanográficas.

Parte das variações registradas nos dois testemunhos se encaixa dentro do esperado para as variações climáticas globais associadas a mudanças na circulação oceânica e atmosférica. Tal como esperado, se verificou a ocorrência de um aquecimento e aumento de salinidade na área de estudo em períodos de desaceleração da célula de transporte meridional do Atlântico como nos eventos Heinrich 1 e Younger Dryas, resultado da redução da exportação de calor e sal para o Hemisfério Norte. De maneira oposta, o restabelecimento do fluxo de calor e sal para o Atlântico Norte se refletiu em períodos de redução da temperatura e salinidade como no período Bolling/Allerod e início do Holoceno.

Outra parte significativa da variabilidade parece estar relacionada à intensidade do Sistema de Monção da América do Sul resultante de variações na insolação de acordo com o ciclo de precessão. Por estarem associadas a importantes mudanças no ciclo hidrológico, as variações no Sistema de Monção se refletiram nas curvas de variação da composição isotópica da água do mar e, conseqüentemente, salinidade. Nos períodos de maior insolação (Último Máximo Glacial e final do Holoceno), uma maior atividade na Zona de Convergência do Atlântico Sul associada a um sistema de monção fortalecido teriam sido responsáveis por um significativo aumento da precipitação. Tais observações estão de acordo com o registro de variações no aporte de sedimentos terrígenos na área de estudo, representado pelas razões Ti/Ca e Fe/Ca.

Os principais desvios da tendência de variação da composição isotópica da água do mar esperada em função das mudanças de insolação parecem estar associados aos grandes pulsos de degelo ocorridos em torno de 19, 14 e 8,2 mil anos AP.

Levando em consideração o maior espaçamento entre amostras e as limitações do modelo de idade do testemunho SAN76 comparado ao testemunho KF02, observouse uma clara semelhança nas estimativas de paleotemperatura e, em menor grau, paleossalinidade. Apesar disto, os dois testemunhos apresentaram diferenças significativas na composição da fauna de foraminíferos planctônicos as quais foram 
atribuídas a variações locais de paleoprodutividade, provavelmente relacionadas a diferentes processos de fertilização. Especula-se que variações do regime de ressurgência e da influência da pluma do Rio da Prata tenham cumprido um papel fundamental na determinação das variações e diferenças de paleoprodutividade entre os dois locais estudados. Tais variações estariam relacionadas a mudanças no regime de ventos e diferentes configurações da costa resultantes de variações do nível do mar. 


\section{REFERÊNCIAS BIBLIOGRÁFICAS}

Alley, R.B.; Mayewski, P.A.; Sowers, T.; Stuiver, M.; Taylor, K.C.; Clark, P.U. 1997. Holocene climatic instability: a prominent, widespread event 8200 years ago. Geology, 25: $483-486$.

An, Z.; Porter, S.C.; Kutzbach, J.E.; Xihao, W.; Suming, W.; Xiaodong, L.; Xiaoqiang, L.; Weijian, Z. 2000. Asynchronous Holocene optimum of the East Asian monsoon. Quat. Sci. Rev., 19, 743-762.

Andrade, K.M.; Cavalcanti, I.F.A. 2004. Climatologia dos sistemas frontais e padrões de comportamento para o verão na América do Sul. Anais do XIII Congresso Brasileiro de Meteorologia (CD), Sociedade Brasileira de Meteorologia, Fortaleza.

Andreasen, D.J.; Ravelo, A.C. 1997. Tropical Pacific Ocean Thermocline Depth Reconstructions for the Last Glacial Maximum. Paleoceanography, 12(3): 395-413.

Antonov, J.I.; Locarnini, R.A.; Boyer, T.P.; Mishonov, A.V.; Garcia, H.E. 2006. World Ocean Atlas 2005, Volume 2: Salinity. S. Levitus, Ed. NOAA Atlas NESDIS 62, U.S. Government Printing Office, Washington, D.C., 182 pp.

Arz, H.W.; Pätzold, J.; Wefer, G. 1999. The deglacial history of the western tropical Atlantic as inferred from high resolution stable isotope records off northeastern Brazil. Earth Planet. Sci. Lett., 167: 105-117.

Azevedo, R.L.M.; Rodrigues, R.; Takaki, T. 1997. Aplicação dos dados isotópicos de carbono e oxigênio, de rocha-total, em estudos paleoambientais. Bol. Geoc. Petrobras, $11(1 / 2): 19-32$.

Baker, P.A., Seltzer, G.O., Fritz, S.C., Dunbar, R.B., Grove, M.J., Tapia, P.M., Cross, S.L., Rowe, H.D., and Broda, J.P., 2001a, The history of South American tropical precipitation for the past 25,000 years. Science, 291, 640-643.

Baker, P.A.; Rigsby. C.A.; Seltzer, G.O.; Fritz, S.C.; Lowenstein, T.K.; Bacher, N.P.; Veliz, C. 2001b. Tropical climate changes at millennial and orbital timescales on the Bolivian Altiplano. Nature, 409, 698-701.

Baldini, J.U.L.; McDermott, F.; Fairchild, I.J. 2002. Structure of the 8200-year cold event revealed by a speleothem trace element record. Science, 296: 2203-2206.

Bard, E. 2001. Paleoceanographic implications of the difference in deep-sea sediment mixing between large and fine particles. Paleoceanography, 16(3): 235-239.

Bard, E.; Rostek, F.; Sonzogni, C. 1997. Interhemispheric Synchrony of the Last Deglaciation Inferred from Alkenone Palaeothermometry. Nature, 385: 707-710.

Bariani, L.M. 2009. Variações da sedimentação ao longo dos últimos 15.000 anos em um testemunho da Bacia de Santos. Trabalho de conclusão de curso (Bacharelado). Instituto Oceanográfico, Univ. de São Paulo, 39pp.

Barker, S.; Diz, P.; Vautravers, M.J.; Pike, J.; Knorr, G.; Hall, I.R.; Broecker, W.S. 2009. Interhemispheric Atlantic seesaw response during the last deglaciation. Nature, 457: 1097-1103. 
Bastos, C.C.; Ferreira, N.J. 2000. Análise climatológica da Alta Subtropical do Atlântico Sul. Anais do XI Congresso Brasileiro de Meteorologia, Rio de Janeiro. Sociedade Brasileira de Meteorologia, pp. 612-619.

Bé, A.W.H. 1967. Foraminifera families: Globigerinidae and Globorotaliidae. Conseil Permanent International pour l'exploration de la mer. Zooplankton, Sheet 108. 9 pp.

Bé, A.W.H. 1977. An ecological, zoogeographic and taxonomic review of recent planktonic foraminifera. In: Oceanic Micropaleontology, Ramsay, A.T.S. (Ed.), Academic Press, London, pp. 1-100.

Bé, A.W.H.; Hemleben, C.; Anderson, O.R.; Spindler, M.; Hacunda, J.; Tuntivate-Choy, S. 1977. Laboratory and field observations of living planktonic foraminifera. Micropaleontology, 23(2): 155-179.

Bé, A.W.H.; Bishop, J.K.B.; Sverdlove. M.S.; Gardner, W.D. 1985. Standing stock, vertical distribution and flux of planktonic foraminifera in the Panama Basin. Mar. Micropaleontol., 9:307-333.

Beck, J.W.; Récy, J.; Taylor, F.; Edwards, R.L.; Cabioch, G. 1997. Abrupt changes in early Holocene tropical sea surface temperature derived from coral records. Nature, 385: 705707.

Belhing, H. 2002, South and southeast Brazilian grasslands during Late Quaternary Times: a synthesis. Palaeogeogr. Palaeoclimatol. Palaeoecol., 177, 19-27

Behling, H.; Lichte, M. 1997. Evidence of Dry and Cold Climatic Conditions at Glacial times in Tropical Southeastern Brazil. Quat. Res., 48, 348-358.

Behling, H.; Dupont, L.; Safford, H.D.; Wefer, G. 2007. Late Quaternary vegetation and climate dynamics in the Serra da Bocaina, Southeastern Brazil. Quat. Int., 161: 22-31.

Benway, H.M.; Mix, A.C. 2004. Oxygen isotopes, upper-ocean salinity, and precipitation sources in the eastern tropical Pacific, Earth Planet. Sci. Lett., 224: 493-507.

Berger, A. 1993. Milankovitch effects on long-term climatic changes. Les Cahiers du MURS, 30/31: 61- 78.

Berger A.; Loutre M.F. 1991. Insolation values for the climate of the last 10 million years. Quat. Sci. Rev., 10 (4): 297-317.

Berger, W.H., 1973. Deep-sea carbonates; Pleistocene dissolution cycles. J. Foram. Res., 3(4): 187-195.

Berger, W.H.; Bé, A. W.H.; Vincent, E. 1981, Oxygen and Carbon Isotopes in Foraminifera. Palaeogeogr., Palaeoclimatol., Palaeoecol., 33: 1.

Bijma, J.; Hemleben, C.; Oberhaensli, H.; Spindler, M. 1992. The effects of increased water fertility on tropical spinose planktonic foraminifers in laboratory cultures. J. Foram. Res., 22: 242-256.

Bijma, J.; Altabet, M.; Conte, M.; Kinkel, H.; Versteegh, G.J.M.; Volkman, J.K.; Wakeham, S.G.; Weaver, P.P. 2001. Primary signal: Ecological and environmental factors- Rep. Working Group 2. Geochem. Geophys. Geosys., 2: 200GC000051. 
Bird, B.W., Kirby, M.E. 2006, An alpine lacustrine record of early Holocene North American Monsoon dynamics from Dry Lake, southern California (USA). J. Paleolimnol., 35, 179-192.

Blunier, T.; Chappellaz, J.; Schwander, J.; Dällenbach, A.; Stauffer, B.; Stocker, T.F.; Raynaud, D.; Jouzel, J.; Clausen, H.B.; Hammer, C.U.; Johnsen, S.J. 1998. Asynchrony of Antarctic and Greenland Climate Change During the Last Glacial Period. Nature, 394: 739-743.

Bolli, H.M.; Saunders, J.B. 1989. Oligocene to Holocene low latitude planktic foraminifera. In: Plankton Stratigraphy, Vol.1. Bolli, H.M.; Saunders, J.B.; Perch-Nielsen, K. (Eds.). Cambridge Earth Sci. Series. Cambridge Univ. Press, pp: 155-262.

Bond, G.; Kromer, B.; Beer, J.; Muscheler, R.; Evans, M.N.; Showers, W.; Hoffmann, S.; Lotti-Bond, R.; Hajdas, I.; Bonani, G. 2001. Persistent solar influence on North Atlantic climate during the Holocene. Science, 294: 2130-2136.

Bond, G.; Showers, W.; Cheseby, M.; Lotti, R.; Almasi, P.; deMenocal, P.; Priore, P.; Cullen, H.; Hajdas, I.; Bonani, G. 1997. A pervasive millennial-scale cycle in North Atlantic Holocene and Glacial climates. Science, 278: 1257-1266.

Boyle, E.A. 1990. Quaternary Deepwater Paleoceanography. Science, 249: 863-870.

Boyle, E.A.; Keigwin, L. 1987. North Atlantic thermohaline circulation during the past 20,000 years linked to high latitude surface temperature. Nature, 330: 35-40.

Braconnot, P.; Otto-Bliesner, B.; Harrison, S.; Joussaume, S.; Peterchmitt, J.-Y.; AbeOuchi, A.; Crucifix, M.; Driesschaert, E.; Fichefet, T.; Hewitt, C.D.; Kageyama, M.; Kitoh, A.; Loutre, M.-F.; Marti, O.; Merkel, U.; Ramstein, G.; Valdes, P.; Weber, L.; Yu, Y.; Zhao, Y. 2007. Results of PMIP2 coupled simulations of the Mid-Holocene and Last Glacial Maximum - Part 2: Feedbacks with emphasis on the location of the ITCZ and mid-and high latitudes heat budget. Climate of the Past, 3: 279-296.

Bradley, R.S. 1985. Quaternary Paleoclimatology: Methods of Paleoclimatic Reconstruction. Unwin Hyman, Inc., Winchester, Mass. USA. 472 pp.

Bradley, R.S. 2000. Past global changes and their significance for the future. Quat. Sci. Rev., 19: 391-402.

Brassell, S.C.; Eglinton, G.; Marlowe, I.T.; Pflaumann, U.; Sarnthein, M. 1986. Molecular stratigraphy: a new tool for climatic assessment. Nature, 320: 129-133.

Broccoli, A.J.; Dahla, K.A.; Stouffer, R.J. 2006. Geophys. Res. Lett., 33, L01702, p. 1-4.

Broecker, W.S. 1989. The salinity contrast between the Atlantic and Pacific oceans during glacial time. Paleoceanography, 4(2): 207-212.

Broecker, W.S. 1997a. Future Directions of Paleoclimate Research. Quat. Sci. Rev., 16: 821-825.

Broecker, W.S. 1997b. Thermohaline Circulation, the Achilles Heel of Our Climate System: Will Man-Made $\mathrm{CO}_{2}$ Upset the Current Balance? Science, 278: 1582-1588.

Broecker, W.S. 1989. The salinity contrast between the Atlantic and Pacific oceans during glacial time. Paleoceanography, 4(2): 207-212. 
Broecker, W.S. 2000. Abrupt Climate Change: Causal Constraints Provided by the Paleoclimate Record. Earth-Sci. Rev., 51: 137-154.

Broecker, W.S. 2003. Does the trigger for abrupt climate change reside in the ocean or in the atmosphere? Science. 300: 1519-1522.

Broecker, W.S. 2006. Abrupt climate change revisited. Global Planet. Change, 54: 211-215.

Broecker, W.S.; Denton, G.H. 1990. The role of ocean-atmosphere reorganizations in glacial cycles. Quat. Sci. Rev., 9: 305-341.

Bush, M.B., de Oliveira, P.E.; Colinvaux, P.A.; Miller, M.C.; Moreno, J.E. 2004. Amazonian paleoecological histories: one Hill, three watersheds. Palaeogeogr. Palaeoclimatol. Palaeoecol., 214: 359-393.

Butzin, M., Prange, M.; Lohmann, G. 2005. Radiocarbon simulations for the glacial ocean: the effects of wind stress, Southern Ocean sea ice and Heinrich events. Earth Planet. Sci. Lett., 235, 45-61.

Came, R.E.; Oppo, D.W.; Curry, W.B., 2003. Atlantic Ocean circulation during the Younger Dryas: Insights from a new $\mathrm{Cd} / \mathrm{Ca}$ record from the western subtropical South Atlantic. Paleoceanography, 18(4): 1086.

Campos, E.J.D.; Gonçalves, J.E.; Ikeda, Y. 1995. Water mass characteristics and geostrophic circulation in the South Brazil Bight: Summer of 1991. J. Geophys. Res., 100 (C9): 18537-18550.

Campos, E.J.D.; Lentini, C.A.D.; Miller, J.L.; Piola, A.R. 1999. Interannual variability of the sea surface temperature in the South Brazil Bight. Geophys. Res. Lett., 26(14): 2061-2064.

Campos, E.J.D.; Velhote, D.; da Silveira, I.C.A. 2000. Shelf break upwelling driven by Brazil Current cyclonic meanders. Geophys. Res. Lett., 27(6): 751-754.

Cane, M.A. 2005. The evolution of El Niño, past and future. Earth Planet. Sci. Lett., 230: 227-240.

Cao, L., Fairbanks, R.G.; Butzin, M.; Naik, N., em prep. The marine radiocarbon reservoir age. Radiocarbon.

Carrington, D.P.; Gallimore, R.G.;Kutzbach, J.E. 2001. Climate sensitivity to wetlands and wetland vegetation in mid-Holocene North Africa. Clim. Dyn., 17: 151-157.

Carton, J.A.; Cao, X.; Giese, B.S.; da Silva, A.M. 1996. Decadal and interannual SST variability in the Tropical Atlantic Ocean. J. Phys. Ocean., 26: 1165-1175.

Carvalho, L.M.V.; Jones, C.; Liebmann, B. 2002. Extreme precipitation events in southeastern South America and large-scale convective patterns in the South Atlantic Convergence Zone. J. Clim., 15: 2377-2394.

Carvalho, L.M.V.; Jones, C.; Liebmann, B. 2004. The South Atlantic Convergence Zone: Intensity, Form, Persistence, and Relationships with intraseasonal to interannual activity and extreme rainfall. J. Clim., 17: 88-108.

Castelão, R.M.; Campos, E.J.D.; Miller, J.L. 2004. A modelling study of coastal upwelling driven by Wind and meanders of the Brazil Current. J. Coast. Res., 20(3): 662-671. 
Castro, B.M.; Miranda, L.B. 1998. Physical oceanography of the western Atlantic continental shelf located between $4^{\circ} \mathrm{N}$ and $34^{\circ} \mathrm{S}$, Coastal segment $(4, \mathrm{~W})$. In: Robinson, A.R.; Brink, K.H. (Eds.), The Sea, Vol. 11. John Wiley \& Sons, Inc.

Cavalcanti, I.F.A. 1996. Episódios El Niño/Oscilação Sul durante a década de 1986 a 1996 e suas influências sobre o Brasil. In: Climanálise Especial, Edição comemorativa de 10 anos. MCT/INPE-CPTEC

Chapman, M.R.; Shackleton, N.; Duplessy, J.C. 2000. Sea surface temperature variability during the last glacial- interglacial cycle: Assessing the magnitude and pattern of climate change in the North Atlantic. Palaeogeogr. Palaeoclimatol. Palaeoecol., 157: 125.

Charles, C.D.; Lynch-Stieglitz, J.; Ninnemann, U.S.; Fairbanks, R.G. 1996. Climate connections between the hemispheres revealed by deep-sea sediment core/ice core correlations. Earth Planet. Sci. Lett., 142: 19-27.

Cheng, H.; Fleitmann, D.; Edwards, R.L.; Wang, X.; Cruz, F.W.; Auler, A.S.; Mangini, A.; Wang, Y.; Kong, X.; Burns, S.J.; Matter, A. 2009. Timing and structure of the $8.2 \mathrm{kyr}$ event inferred from $\delta^{18} \mathrm{O}$ records of stalagmites from China, Oman, and Brazil. Geology, 37(11): 1007-1010.

Chiessi, C.M.; Mulitza, S.; Pätzold, J.; Wefer, G.; Marengo, J.A. 2008. Possible impact of the Atlantic Multidecadal Oscillation on the South American summer monsoon. Geophys. Res. Lett., 36, L21707, p.1-5.

Cirano, M.; Mata, M.M.; Campos, E.J.D.; Deiró, N.F.R. 2006. A circulação oceânica de larga-escala na região oeste do Atlântico Sul com base no modelo de circulação global OCCAM. Rev. Bras. Geofís., 24(2): 209-230.

Clark, P.U.; Mitrovica, J.X.; Milne, G.A.; Tamisiea, M.E. 2002. Sea-level fingerprinting as a direct test for the source of Global Meltwater Pulse 1A. Science, 295: 2438- 2441.

Clark, P.U.; McCabe, A.M.; Mix, A.C.; Weaver, A.J. 2004. Rapid rise of sea level 19,000 years ago and its global implications. Science, 304:1141-1144.

Claussen, M.; Kubatzki, C.; Brovkin, V.; Ganopolski, A.; Hoelzmann, P.; Pachur, H.J. 1999. Simulation of an abrupt change in Saharan vegetation in the mid-Holocene. Geophys. Res. Lett., 26(14): 2037-2040.

CLIMAP 1976. The Surface of the Ice-Age Earth. Science, 191 (4232): 1131-1137.

CLIMAP 1981. Seasonal Reconstructions of the Earth's Surface at the Last Glacial Maximum. Geol. Soc. Am. Map \& Chart Ser. MC-36:1-18.

COHMAP 1988. Climatic changes of the last 18,000 years: Observations and model simulations. Science, 241: 1043-1052.

Colinvaux, P.A.; de Oliveira, P.E.; Bush, M.B. 2000. Amazonian and neotropical plant communities on glacial time-scales: The failure of the aridity and refuge hypotheses. Quat. Sci. Rev., 19: 141-169.

Colinvaux, P.A.; de Oliveira, P.E. 2001. Amazon plant diversity and climate through the Cenozoic. Palaeogeogr. Palaeoclimatol. Palaeoecol., 166: 51-63. 
Conan, S.M.H.; Ivanova, E.M.; Brummer, G.J.A. 2002. Quantifying carbonate dissolution and calibration of foraminiferal dissolution indices in the Somali Basin. Mar. Geol., $182: 325-349$

Conti, L.A.; Furtado, V.V. 2006. Geomorfologia da plataforma continental do Estado de São Paulo. Rev. Bras. Geoc., 36 (2): 305-312.

Conti, L.A.; Furtado, V.V. 2009. Topographic registers of paleo-valleys on the Southeastern Brazilian Continental shelf. Braz. J. Oceanogr., 57(2): 113-121.

Costa, K.B. 2000. Variações paleoceanográficas na porção oeste do Atlântico Sul entre o Último Máximo Glacial e o Holoceno: Isótopos estáveis de oxigênio e carbono e a razão $\mathrm{Cd} / \mathrm{Ca}$ em foraminíferos bentônicos. Tese de Doutorado, Instituto de Geociências, Univ. Federal do Rio Grande do Sul. 236 pp.

Craig, H.; Gordon, L.I. 1965. Deuterium and oxygen 18 variations in the ocean and the marine atmosphere. In: Tongiorgi, E. (Ed.), Stable isotopes in oceanographic studies and paleotemperatures. Consiglio Nazional delle Richerche, Spoleto, Italy, pp. 9-130.

Cross, S.L.; Baker, P.A.; Seltzer, G.O.; Fritz, S.C; Dunbar, R.B. 2001. Late Quaternary climate and hydrology of tropical South America inferred from an isotopic and chemical model of Lake Titicaca, Bolivia and Peru. Quat. Res., 56: 1-9.

Crowley, T.J. 2000. CLIMAP SSTs re-revisited. Clim. Dyn., 16: 241-255.

Crowley, T.J.; North, G.R. 1991. Paleoclimatology. Oxford Monographs on Geology and Geophysics, \#18, Oxford University Press, New York, 349 pp.

Cruz Jr, F.W.; Burns, S.J.; Karmann, I.; Sharp. W.D.; Vuille, M.; Cardoso, A.O.; Ferrari, J.A.; Silvas Dias, P.L.; Viana Jr, O. 2005a. Insolation-driven changes in atmospheric circulation over the past 116,000 years in subtropical Brazil. Nature, 434, 63-66.

Cruz Jr, F.W.; Karmann, I.; Viana Jr, O.; Burns, S.J.; Ferrari, J.A.; Vuille, M.; Sial, A.N.; Moreira, M.Z. 2005b. Stable isotope study of cave percolation waters in subtropical Brazil: Implications for paleoclimate inferences from speleothems. Chem. Geol., 220: 245-262.

Cruz Jr., F.W.; Burns, S.J.; Karmann, I.; Sharp, W.D.; Vuille, M. 2006. Reconstruction of regional atmospheric circulation features during the late Plesitocene in subtropical Brazil from oxygen isotope composition of speleothems. Earth Planet. Sci. Lett., 248: 494-506.

Cullen, J.L. 1981. Microfossil evidence for changing salinity patterns in the Bay of Bengal over the last 20.000 years. Palaeogeogr. Palaeoclimatol. Palaeoecol. 35, 315-356.

Curry, W.B.; Oppo, D.W. 2005. Glacial water mass geometry and the distribution of $\delta^{13} \mathrm{C}$ of $\Sigma \mathrm{CO}_{2}$ in the western Atlantic Ocean. Paleoceanography 20, PA1017:1-12.

Dahl, K.A.; Broccoli, A.J.; Stouffer, R.J. 2005. Assessing the role of North Atlantic freshwater forcing in millennial scale climate variability: A tropical Atlantic perspective. Clim. Dyn., 24: 325-346.

Damuth, J.E. 1977. Late Quaternary sedimentation in the western equatorial Atlantic. Geol. Soc. Am. Bull., 88(5): 695-710.

Dansgaard, W. 1964. Stable isotopes in precipitation. Tellus, 16: 436-468. 
de Menocal, P.; Ortiz, J.; Guilderson, T.; Adkins, J.; Sarnthein, M.; Baker, L.; Yarusinsky, M. 2000. Abrupt onset and termination of the African Humid Period: rapid climate responses to gradual insolation forcing. Quat. Sci. Rev., 19: 347-361.

Denton, G.H.; Broecker, W.S. 2008. Wobbly ocean conveyor circulation during the Holocene? Quat. Sci. Rev., 27: 1939-1950.

De Ruijter, W.P.M.; Biastoch, A.; Drijfhout, S.S.; Lutjeharms, J.R.E.; Matano, R.P.; Pichevin, T.; van Leeuwen, P.J.; Weijer, W. 1999. Indian- Atlantic interocean exchange: Dynamics, estimation and impact. J. Geophys. Res., 104(C9): 20885-20910.

Deuser, W.G.; Ross, E.H. 1989. Seasonally abundant planktonic foraminifera of the Sargasso Sea: succession, deep-water fluxes, isotopic compositions, and paleoceanographic implications. J. Foram. Res., 19(4): 268-293.

de Vargas, C.; Renaud, S.; Hilbrecht, H.; Pawlowski, J. 2001. Pleistocene adaptative radiation in Globorotalia truncatulinoides: genetic, morphologic, and environmental evidence. Paleobiology, 27: 104-125.

de Vernal, A.; Hillaire-Marcel, C. 2000. Sea-ice cover, sea-surface salinity and halothermocline structure of the northwest North Atlantic: modern versus full glacial conditions. Quat. Sci. Rev., 19: 65-85.

Diaz, A.F.; Studzinski, C.D.; Mechoso, C.R. 1998. Relationships between precipitation anomalies in Uruguay and Southern Brazil and sea surface temperature in the Pacific and Atlantic oceans. J. Clim., 11:251-271.

Douglass, D.C.; Singer, B.S.; Kaplan, M.R.; Ackert, R.P.; Mickelson, D.M.; Caffee, M.W. 2005. Evidence of early Holocene glacial advances in southern South America from cosmogenic surface-exposure dating. Geology, 33(3): 237-240.

Duarte, C.S.L.; Viana, A.R. 2007. Santos Drift System: Startigraphic organization and implications for the late Cenozoic palaeocirculation in the Santos Basin, SW Atlantic Ocean. In : Economic and palaeoceanographic significance of contourite deposits (Viana, A.R; Rebesco, M., Eds.) Geol. Soc. London, Spec. Publ., 276: 171-198.

Dunbar, R.B. 2003. Leads, lags and the tropics. Nature, 421: 121-122.

Duplessy, J.C.; Labeyrie, L.; Arnold, M.; Paterne, M.; Duprat, J.; van Weering, T.C.E. 1992. Changes in surface salinity of the North Atlantic Ocean during the last deglaciation. Nature, 358: 485-488.

Duplessy, J.C.; Labeyrie, L.; Juillet-Leclerc, A.; Maitre, F.; Duprat, J.; Sarnthein, M. 1991. Surface salinity reconstruction of the North Atlantic Ocean during the last glacial maximum. Oceanol. Acta, 14: 311-324.

Duplessy, J.C.; Labeyrie, L.; Waelbroeck, C. 2002. Constraints on the ocean oxygen isotopic enrichment between the Last Glacial Maximum and the Holocene: Paleoceanographic implications. Quat. Sci. Rev.,21: 315-330.

Duplessy, J.C.; Shackleton, N.J.; Fairbanks, R.G.; Labeyrie, L.; Oppo, D.; Kallel, N. 1988. Deepwater source variations during the last climate cycle and their impact on the global deepwater circulation. Paleoceanography, 3(3): 343-360. 
Dürkoop, A.; Hale, W.; Mulitza, S.; Pätzold, J.; Wefer, G. 1997. Late Quaternary variations of sea surface salinity and temperature in the western tropical Atlantic: Evidence from $\delta^{18} \mathrm{O}$ of Globigerinoides sacculifer. Paleoceanography, 12(6): 764-772.

Ehleringer, J.R.; Cerling, T.E.; Helliker, B.R. 1997. $\mathrm{C}_{4}$ photosynthesis, atmospheric $\mathrm{CO}_{2}$, and climate. Oecologia, 112: 285-299.

Emiliani, E. 1954. Depth habitats of some species of pelagic foaminifera as indicated by oxygen isotope ratios. Am. J. Sci., 252: 149-158.

EPICA Community Members 2004. Eight glacial cycles from an Antarctic ice core. Nature, 429: 623-628.

Ericson, D.B., Wollin, G. 1968. Pleistocene Climates and Chronology of Deep-Sea Sediments. Science, 162 (3859): 1227-1234.

Ericson, D.B.; Wollin, G.; Wollin, J. 1955. Coiling Direction of Globorotalia truncatulinoides in Deep-Sea Cores. Deep Sea Res., 2(2):152.

Fairbanks, R.G. 1989. Glacio-eustatic sea level record 0-17,000 years before present: influence of glacial melting rates on Younger Dryas event and deep ocean circulation. Nature, 342: 637-642.

Fairbanks, R.G.; Mortlock, R.A.; Chiu, T.-C.; Cao, L.; Kaplan, A.; Guilderson, T.P.; Fairbanks, T.W.; Bloom, A.L.; Grootes, P.M.; Nadeau, M.-J. 2005. Radiocarbon calibration curve spanning 0 to 50,000 years BP based on paired ${ }^{230} \mathrm{Th} /{ }^{234} \mathrm{U} /{ }^{238} \mathrm{U}$ and ${ }^{14} \mathrm{C}$ dates on pristine corals. Quat. Sci. Rev., 24(16-17): 1781-1796.

Farmer, E.C.; deMenocal, P.B.; Marchitto, T.M. 2005. Holocene and deglacial ocean temperature variability in the Benguela upwelling region: Implications for low-latitude atmospheric circulation. Paleoceanography, 20: PA2018, p. 1-16.

Farrera, I.; Harrison, S.P.; Prentice, I.C.; Ramstein, G.; Guiot, J.; Bartlein, P.J.; Bonnefille, R.; Bush, M.; Cramer, W.; von Grafenstein, U.; Holmgren, K.; Hooghiemstra, H.; Hope, G.; Jolly, D.; Lauritzen, S.-E.; Ono, Y.; Pinot, S.; Stute, M.; Yu, G. 1999. Tropical climates at the Last Glacial Maximum: a new synthesis of terrestrial palaeoclimate data. I. Vegetation, lake-levels and geochemistry. Clim. Dyn., 15: 823856.

Ferreira, N.S. 1996. Zona de Convergência Intertropical. In: Climanálise Especial, Edição comemorativa de 10 anos. MCT/INPE-CPTEC

Flückiger, J.; Knutti, R.; White, J.W.C. 2006. Oceanic processes as potential trigger and amplifying mechanisms for Heinrich events. Paleoceanography, 21: PA2014.

Firestone, R.B.; West, A.; Kennett, J.P.; Becker, L.; Bunch, T.E.; Revay, Z.S.; Schulz, P.H.; Belgya, T.; Kennett, D.J.; Erlandson, J.M.; Dickenson, O.J.; Goodyear, A.C.; Harris, R.S.; Howard, G.A.; Kloosterman, J.B.; Lechler, P.; Mayewski, P.A.; Montgomery, J.; Poreda, R.; Darrah, T.; Que Hee, S.S.; Smith, A.R.; Stich, A.; Topping, W.; Wittke, J.H.; Wolbach, W.S. 2007. Evidence for an extraterrestrial impact 12,900 years ago that contributed to the megafaunal extinctions and the Younger Dryas cooling. Proc. Natl. Acad. Sci., 104 (41): 16016-16021. 
Fraguas, P.F. 2009. Relação entre o sinal isotópico de oxigênio e carbono e o tamanho de testa de foraminíferos em amostras de topo de dois testemunhos da Margem Continental Brasileira. Diss. Mestrado. Inst. Oc., Univ. São Paulo. 105 pp.

Frenz, M.; Henrich, R. 2007. Carbonate dissolution revealed by silt grain-size distribution: comparison of Holocene and Last Glacial Maximum sediments from the pelagic South Atlantic. Sedimentology, 54: 391-404.

Frenz, M.; Höppner, R.; Stuut, J.-B.W.; Wagner, T.; Henrich, R. 2003. Surface sediment bulk geochemistry and grain-size composition related to the oceanic circulation along the South American Continental Margin in the Southwest Atlantic. In: The South Atlantic in the Late Quaternary: Reconstruction of material budgets and current systems. Wefer, G.; Multiza, S.; Ratmeyer, V., (Eds.). Springer-Verlag Berlin Heidelberg New York Tokyo, pp. 347-373.

Gaeta, S.A.; Brandini, F.P. 2006. Produção primária do fitoplâncton na região entre o Cabo de São Tomé (RJ) e o Chuí (RS). In: Rossi-Wongtschowski, C.L.D.B.; Madureira, L., S.-P., O Ambiente Oceanográfico da plataforma continental e do talude na região Sudeste-Sul do Brasil. Edusp, p. 219-264.

Gan, M.A.; Rao, V.B. 1991. Surface cyclogenesis over South America. Mon. Weather Rev., 119: 1293- 1302.

Garcia, C.A.E; Sarma, Y.V.B.; Mata, M.M.; Garcia, V.M.T. 2004. Chlorophyll variability and eddies in the Brazil-Malvinas Confluence region. Deep-Sea Res.II, 51: 159-172.

Garreaud, R. D.; Wallace, J.M. 1998. Summertime incursions of midlatitude air into subtropical and tropical South America. Mon. Weather Rev., 126: 2713-2733.

Gat, J.R.; Mook, W.G.; Meijer, H.A.J. 2001. Atmospheric water. In: Mook, W.G. (Ed.), Environmental Isotopes in the Hydrological Cycle: Principles and Applications. IHP-V I Tech. Doc. Hydrology I No. 39, Vol II, UNESCO, Paris.

Gersonde, R.; Abelmann, A.; Brathauer, U.; Becquey, S.; Bianchi, C.; Cortese, G.; Grobe, H.; Kuhn, G.; Niebler, H.-S; Segl, M.; Sieger, R.; Zielinski, U.; Fütterer, D.K. 2003. Last glacial sea surface temperatures and sea-ice extent in the Southern Ocean (Atlantic-Indian sector): A multiproxy approach. Paleoceanography, 18(3): 1061.

Gersonde, R.; Crosta, X.; Abelmann, A.; Armand, L. 2005. Sea-surface temperature and sea ice distribution of the Southern Ocean at the EPILOG Last Glacial Maximum- a circum-Antarctic view based on siliceous microfossil records. Quat. Sci. Rev., 24: 869896.

Gherardi, J.-M.; Labeyie, L.; McManus, J.F.; Francois, R.; Skinner, L.C.; Cortijo, E. 2005. Evidence from the Northeastern Atlantic basin for variability in the rate of the meridional overturning circulation through the last deglaciation. Earth Planet. Sci. Lett., 240: 710-723.

Gherardi, J.-M.; Labeyie, L.; Nave, S.; Francois, R.; McManus, J.F.; Cortijo, E. 2009. Glacial-interglacial circulation changes inferred from ${ }^{231} \mathrm{~Pa} /{ }^{230} \mathrm{Th}$ sedimentary Record in the North Atlantic region. Paleoceanography, 24: PA2204,14p.

Goelzer, H.; Mignot, J.; Levermann, A.; Rahmstorf, S. 2006. Tropical versus high latitude freshwater influence on the Atlantic circulation. Clim. Dyn., 27: 715-725. 
Gooday, A.J. 2002. Biological responses to seasonally varying fluxes of organic matter to the ocean floor: A review. J. Oceanogr., 58: 305-332.

Goni, G.J.; Wainer, I. 2001. Investigation of the Brazil Current front variability from altimeter data. J. Geophys. Res., 106(C12): 31117-31128.

González-Silveira, A.; Santamaría Del Angel, E.; Millán-Núñez, R. 2006. Spatial and temporal variability of the Brazil-Malvinas Confluence and the La Plata Plume as seen by SeaWIFS and AVHRR imagery. J. Geophys. Res., 111: C06010.

Grimm, A.M. 2003. The El Niño impact on the Summer Monsoon in Brazil: Regional processes versus remote influences. J. Clim., 16(2): 263-280.

Guilderson, T.P.; Fairbanks, R.G.; Rubenstone, J.L. 1994. Tropical temperature variations since 20,000 Years Ago: Modulating interhemispheric climate change. Science, 263: 663-665.

Hajdas, I.; Bonani, G.; Moreno, P.I.; Ariztegui, D. 2003. Precise Radiocarbon Dating of Late-Glacial Cooling in Mid-Latitude South America. Quat. Res., 56:70-78.

Hastenrath, S. 1991. Climate Dynamics of the Tropics. 2a. Ed. Kluwer Academic Publishers, New York, 488 pp.

Haug, G.H.; Hughen, K.A.; Sigman, D.M.; Peterson, L.C.; Röhl, U. 2001. Southward migration of the Intertropical Convergence Zone through the Holocene. Science, 293: 1304-1308.

Hays, J.D.; Imbrie, J., Shackleton, N.J. 1976. Variations in the Earth's Orbit: Pacemaker of the Ice Ages. Science 194 (4270): 1121-1132.

Healy-Williams, N.; Ehrlich, R.; Williams, D.F. 1985. Morphometric and stable isotopic evidence for subpopulations of Globorotalia truncatulinoides. J. Foram. Res., 15(4): 242-253.

Hemleben, C.; Spindler, M.; Anderson, O.R. 1989. Modern planktonic foraminifera. Springer-Verlag, Berlin Heidelberg New York, 363 pp.

Hemming, S.R. 2004. Heinrich Events: Massive Late Pleistocene detritus laters of the North Atlantic and their global climate imprint. Rev. Geophys., 42, RG 1005, 43pp.

Hilbrecht, H. 1996. Extant planktic foraminifera and the physical environment in the Atlantic and Indian Oceans. Mitteilungen aus dem Geologischen Institut der Eidgen. Technischen Hochschule und der Universität Zürich, Neue Folge. No. 300, Zürich.

Hilbrecht, H. 1997. Morphologie gradation and ecology in Neogloboquadrina pachyderma and $N$. dutertrei (planktic foraminifera) from core top sediments. Mar. Micropaleontol., 31: $31-43$.

Hostetler, S.W.; Mix, A.C. 1999. Reasessment of ice-age cooling of the tropical ocean ans atmosphere. Nature, 399: 673-676.

Huang, Y.; Street-Perrott, F.A.; Metcalfe, S.E.; Brenner, M.; Moreland, M.; Freeman, K.H. 2001. Climate change as the dominant control on glacial-interglacial variations in $\mathrm{C} 3$ and C4 plant abundance. Science, 293: 1647-1651.

Hutson, W.H. 1980. The Agulhas Current During the Late Pleistocene: Analysis of Modern Faunal Analogs. Science, 207: 64-66. 
Huybers, P.; Curry, W. 2006. Links between annual, Milankovitch and continuum temperature variability. Nature, 441: 329-332.

Imbrie, J. 1982. Astronomical theory of the Pleistocene Ice Ages: A Brief Historical Review. Icarus, 50: 408-422.

Imbrie, J.; Hays, J.D.; Martinson, D.G.; McIntyre, A.; Mix, A.C.; Morley, J.J.; Pisias, N.G.; Prell, W.L.; Shackleton, N.J. 1984. The orbital theory of Pleistocene climate: Support from a revised chronology of the marine $\delta^{18} \mathrm{O}$ record. In: Milankovitch and climate, Part I. Berger, A.L., Imbrie, J.; Hays, J.D.; Kukla, G.; Saltzman, B. (Eds.), D. Reidel Publ. Co., pp. 269-305.

Imbrie, J.; Imbrie, K.P. 1979. Ice Ages: Solving the Mystery. Harvard University Press, Cambridge Mass. 224pp.

Imbrie, J.; Kipp, N.G. 1971. A New Micropaleontological Method for Quantitative Paleoclimatology: Application to a Late Pleistocene Caribbean Core. In: Late Cenozoic Glacial Ages, Turekian, K.K. (Ed.), New Haven and London, Yale Univ. Press, pp.71147.

Indermühle, A.; Stocker, T.F.; Joos, F.; Fischer, H.; Smith, H.J.; Wahlen, M.; Deck, B.; Mastroianni, D.; Tschmui, J.; Blunier, T.; Meyer, R.; Stauffer, B. 1999. Holocene carbon-cycle dynamics based on $\mathrm{CO}_{2}$ trapped in ice ate Taylor Dome, Antarctica. Nature, 398: 121-126.

Jansen, E.; Overpeck, J.; Briffa, K.R. ; Duplessy, J.-C.; Joos, F.; Masson-Delmotte, V.; Olago, D.; Otto-Bliesner, B.; Peltier, W.R.; Rahmstorf, S.; Ramesh, R.; Raynaud, D.; Rind, D.; Solomina, O.; Villalba, R.; Zhang, D. 2007. Palaeoclimate. In: Climate Change 2007: The Physical Science Basis. Contribution of Working Group I to the Fourth Assessment Report of the Intergovernmental Panel on Climate Change. Solomon, S., Qin. D.; Manning, M.; Chen, Z.; Marquis, M.; Averyt, K.B.; Tignor, M.; e Miller, H.L. (Eds.). Cambridge Univ. Press, Cambridge, UK and New York, NY, USA.

Johns, W.E.; Lee, T.N.; Beardsley, R.C.; Candela, J.; Limeburner, R.; Castro, B. 1998. Annual cycle and variability of the North Brazil current. J. Phys. Ocean., 28(1): 103128.

Joos, F.; Gerber, S.; Prentice, I.C.; Otto-Bliesner, B.L.; Valdes, P.J. 2004. Transient simulations of Holocene atmospheric carbon dioxide and terrestrial carbon since the Last Glacial Maxmimum. Global Biogeochem. Cycles, 18: GB2002.

Kemle-von Mücke, S.; Hemleben, C. 1999. Foraminifera. In: Boltovskoy, D. (Ed.), South Atlantic Zooplankton. Backhuys Publishers, Leiden, Netherlands, pp. 43-73.

Kennett, D.J.; Kennett, J.P.; West, A.; Mercer, C.; Que Hee, S.S.; Bement, L.; Bunch, T.E.; Sellers, M.; Wolbach, W.S. 2009. Nanodiamonds in the Younger Dryas Boundary Sediment Layer. Science, 323: 94.

Kim, S.-T.; O'Neil, J.R. 1997. Equilibrium and nonequilibrium oxygen isotope effects in synthetic carbonates. Geochim. Cosmochim. Acta, 61: 3461-3475.

Kim, J.-H.; Schneider, R.R. 2003. Low-latitude control of interhemispheric sea-surface temperature contrast in the tropical Atlantic over the past 21 kyears: the possible role of SE tarde winds. Clim. Dyn., 21: 337-347. 
Kirby, M.E., Lund, S.P., Anderson, M.A., and Bird, B.W. 2007, Insolation Forcing of Holocene Climate Change in Southern California: A Sediment Study From Lake Elsinore, J. Paleolimnol., 38; 395-417.

Knorr, G.; Lohmann, G. 2003. Southern Ocean origin for the resumption of Atlantic tehrmohaline circulation during deglaciation. Nature, 424: 532-536.

Kodama, Y.M. 1992. Large-Scale Common Features of Sub-Tropical Convergence Zones (the Baiu Frontal Zone, the SPCZ, and the SACZ) Part II : Conditions of the Circulations for Generating the STCZs. J. Meteorol. Soc. of Japan Ser. II, 71(5): 581610.

Kohfeld, K.E.; Harrison, S.P. 2001. DIRTMAP: The geological record of dust. Earth-Sci. Rev., 54: 81-114.

Kowsmann, R.O.; Costa, M.P.A. 1979. Sedimentação Quaternária da Margem Continental Brasileira e das áreas oceânicas adjacentes. Série Projeto REMAC, No. 8. Rio de Janeiro, PETROBRÁS. CENPES, 55 pp.

Kroon, D.; Austin, W.E.N.; Chapman, M.R.; Ganssen, G.M. 1997. Deglacial surface circulation changes in the northeastern Atlantic: Temperature and salinity records off NW Scotland on a century scale. Paleoceanography 12(6): 755-763.

Kucera, M. 2003. Numerical approach to microfossil proxy data. Lecture notes for Summer school Paleoceanography: Theory and field evidence, IAMC Geomare 2003, pp. 66-90.

Kucera, M.; Darling, K.F. 2002. Cryptic Species of Planktonic Foraminifera: Their Effect on Paleoceanographic Reconstructions. Philos. Trans. R. Soc. Lond. A A, 360: 695718.

Kucera, M.; Rosell-Melé, A.; Schneider, R.; Waelbroeck, C.; Weinelt, M. 2005a. Multiproxy approach for the reconstruction of the glacial ocean surface (MARGO). Quat. Sci. Rev., 24: 813-819.

Kucera, M.; Weinelt, M.; Kiefer, T.; Pflaumann, U.; Hayes, A.; Weinelt, M.; Chen, M.-T.; Mix, A.C.; Barrows, T.T.; Cortijo, E.; Duprat, J.; Juggins, S.; Waelbroeck, C. 2005b. Reconstruction of sea-surface temperatures from assemblages of planktonic foraminifera: multi-technique approach based on geographically constrained calibration data sets and its application to glacial Atlantic and Pacific Oceans. Quat. Sci. Rev., 24: 951-998.

Kutzbach, J.; Bonan, G.; Foley, J.; Harrison, S.P. 1996. Vegetation and soil feedbacks on the response of the African monsoon to orbital forcing in the early to middle Holocene. Nature, 384: 623-626.

Kutzbach, J.E.; Guetter, P.J. 1986. The influence of changing orbital parameters and surface boundary conditions on climate simulations for the past 18000 years. J. Atmos. Sci., 43: 1726-1759.

Kutzbach, J.E.; Liu, Z. 1997. Response of the African Monsoon to orbital forcing and ocean feedbacks in the middle Holocene. Science, 278: 440-443.

Kutzbach, J.E.; Otto-Bliesner, B.L. 1982. The sensitivity of the African-Asian monsoonal climate to orbital parameter changes for 9000 years B.P. in a low-resolution general circulation model. J. Atmos. Sci., 39: 1177-1188. 
Labeyrie, L.D.; Duplessy, J.C.; Blanc, P.L. 1987. Variations in mode of formation and temperature of oceanic deep waters over the past 125000 years. Nature, 327: 477-482.

Lambeck, K.; Esat, T.M.; Potter, E.K. 2002. Links between climate and sea levels for the past three million years. Nature, 419: 199-206.

Laprida, C.; Chapori, N.G.; Violante, R.A.; Compagnucci, R.H. 2007. Mid-Holocene evolution and paleoenvironments of the shoreface-offshore transition, north-eastern Argentina: New evidence based on benthic foraminifera. Mar. Geol., 240: 43-56.

Lea, D.W.; Boyle, E.A. 1991. Barium in planktonic foraminifera. Geochim. Cosmochim. Acta, 55: 3321-3331.

LeGrand, P.; Wunsch, C. 1995. Constraints from paleotracer data on the North Atlantic circulation during the last glacial maximum. Paleoceanography, 10(6): 1011-1045.

LeGrande, A.N.; Schmidt, G.A. 2008. Ensemble, water isotope-enabled, coupled general circulation modeling insight sinto the 8.2 ka event. Paleoceanography, 23: PA3207.

Lemos, C.F.; Calbete, N.O. 1996. Sistemas Frontais que atuaram no Brasil de 1987 a 1995. In: Climanálise Especial, Edição comemorativa de 10 anos. MCT/INPE-CPTEC

Lenters, J.D.; Cook, K.H. 1999. Summertime precipitationb variability over South America: role of the large-scale circulation. Mon. Weather Rev., 127: 409-431.

Lentini, C.A.D.; Podestá, G.G.; Campos, E.J.D.; Olson, D.B. 2001. Sea surface temperature anomalies on the Western South Atlantic from 1982 to 1994. Cont. Shelf Res., 21: 89112.

Levitus, S. 1982. Climatological atlas of the world ocean. NOAA Professional Paper 13, US Gov. Printing Office, Washington, D.C.

Levitus, S.; Boyer, T. 1994. World Ocean Atlas 1994 Volume 4: Temperature. NOAA Atlas NESDIS 4, U.S. Dept. of Commerce, Washington, D.C., 132 p.

Little, M.G.; Schneider, R.R.; Kroon, D.; Price, B.; Summerhayes, C.P.; Segl, M. 1997. Trade Wind Forcing of Upwelling, Seasonality, and Heinrich Events as a response to Sub-Milankovitch Climate Variability. Paleoceanography, 12 (4): 568-576.

Liu, Z.; Harrison, S.P.; Kutzbach, J.; Otto-Bliesner, B. 2004. Global Monsoons in the midHolocene and oceanic feedback. Clim. Dyn., 22 (2-3): 157-182.

Liu, Z.; Otto-Bliesner, B.; Kutzbach, J.; Li, L.; Shields, C. 2003. Coupled climate simulation of the evolution of global monsoons in the Holocene. J. Clim., 16: 24722490.

Locarnini, R.A.; Mishonov, A.V.; Antonov, J.I.; Boyer, T.P.; Garcia, H.E. 2006. World Ocean Atlas 2005, Volume 1: Temperature. S. Levitus, Ed. NOAA Atlas NESDIS 61, U.S. Government Printing Office, Washington, D.C., 182 pp.

Lohmann, G.P. 1992. Increasing seasonal upwelling in the subtropical South Atlantic over the past 700000 yrs: Evidence from deep-living planktonic foraminifera. Mar. Micropaleontol., 19: 1-12.

Lohmann, G.P.; Schweitzer, P.N. 1990. Growth and chemistry as probes of the past thermocline, 1, Shell size. Paleoceanography, 5: 55-75. 
Lopes, R.M.; Katsuragawa, M.; Dias, J.F.; Montú, M.A.; Muelbert, J.H.; Gorri, C.; Brandini, F..P. 2006. Zooplankton and ichthyoplankton distribution on the southern Brazilian shelf: an overview. Sci. Mar., 70(2): 189-202.

Lorius, C.; Jouzel, J.; Raynaud, D.; Hansen, J.; Le Treut, H. 1990. The ice-core record: Climate sensitivity and future greenhouse warming. Nature, 347: 139-145.

MacAyeal, D.R. 1993. Binge/purge oscillations of the Laurentide ice sheet as a cause of the North Atlantic's Heinrich events. Paleoceanography, 8(6): 775-784.

Mahiques, M.M.; Bícego, M.C.; Silveira, I.C.A.; Souza, S.H.M.; Lourenço, R.A.; Fukumoto, M.M. 2005. Modern sedimentation in the Cabo Frio upwelling system, Southeastern Brazilian shelf. An. Acad. Bras. Ciênc., 77(3): 535-548.

Mahiques, M.M.; Silveira, I.C.A.; Souza, S.H.M.; Rodrigues, M. 2002. Post-LGM sedimentation on the outer shelf-upper slope of the northernmost part of the São Paulo Bight, southeastern Brazil. Mar. Geol., 181: 387-400.

Mahiques, M.M.; Tassinari, C.C.G.; Marcolini, S.; Violante, R.A.; Figueira, R.C.L.; Silveira, I.C.A.; Burone, L.; Souza, S.H.M. 2008. Nd and Pb isotope signatures on the Southeastern South American upper margin: Implications for sediment transport and source rocks. Mar. Geol., 250: 51-63.

Mahiques, M.M.; Tessler, M.G.; Ciotti, A.M.; da Silveira, I.C.A.; Souza, S.H.M.; Figueira, R.C.L.; Tassinari, C.C.G.. Furtado, V.V.; Passos, R.F. 2004. Hydrodynamically driven patterns of recent sedimentation in the shelf and upper slope off Southeast Brazil. Cont. Shelf Res., 24: 1685-1697.

Mahiques, M.M. ; Wainer, I.K.C.; Burone, L.; Nagai, R.; Sousa, S.H.M.; Figueira, R.C.L.; Silveira, I.C.A.; Bícego, M.C.; Alves, D.P.V.; Hammer, O. 2009. A high-resolution Holocene Record on the Southern Brazilian shelf: Paleoenvironmental implications. Quat. Int., 206:52-61.

Mahowald, N.; Kohfeld, K.; Hansson, M.; Balkanski, Y.; Harrison, S.P.; Prentice, I.C.; Schulz, M.; Rodhe, H. 1999. Dust sources and deposition during the last glacial maximum and current climate: A comparison of model results with paleodata from ice cores and marine sediments. J. Geophys. Res., 104 (D13): 15.895-15.916.

Malmgren, B.A. 1983 Ranking of dissolution susceptibility of planktonic foraminifera at high latitudes of the South Atlantic Ocean. Mar. Micropal., 8: 183-191.

Malmgren, B.A.; Nordlund, U. 1997. Application of Artificial Neural Networks to Paleoceanographic Data. Palaeogeogr. Palaeoclimatol. Palaeoecol., 136: 359-373.

Malmgren, B.A.; Kucera, M.; Nyberg, J.; Waelbroeck, C. 2001. Comparison of statistical and artificial neural network techniques for estimating past sea surface temperatures from planktonic foraminifer census data. Paleoceanography 16(5): 520-530.

Manabe, S.; Stouffer, R.J. 1997. Coupled ocean-atmosphere model response to freshwater input: comparison to the Younger Dryas event. Paleoceanography, 12, 321-336.

Marchal, O.; François, R.; Stocker, T.F.; Joos, F. 2000. Ocean thermohaline circulation and sedimentary ${ }^{231} \mathrm{~Pa} /{ }^{230} \mathrm{Th}$ ratio. Paleoceanography, 15(6): 625-641. 
Marchitto, T.M.; Broecker, W.S. 2006. Deep water mass geometry in the glacial Atlantic Ocean: A review of constraints from the paleonutrient proxy $\mathrm{Cd} / \mathrm{Ca}$. Geochemistry, Geophysics, Geosystems, 7(12): 1-16.

MARGO Project Members 2009. Constraints on the magnitude and patterns of ocean cooling at the Last Glacial Maximum. Nature Geoscience, 2:127-132.

Martin, L.; Bertaux, J.; Corrège, T.; Ledru, M.P.; Mourguiart, P.; Sifeddine, A.; Soubiès, F.; Wirrmann, D.; Suguio, K., Turcq, B. 1997. Astronomical forcing of contrasting rainfall changes in tropical South America between 12.400 e 8.800 cal yr B. P. Quat. Res., 47: 117-122.

Martinez, J.I.; De Deckker, P.; Chivas, A.R. 1997. New estimates for salinity changes in the Western Pacific Warm Pool during the Last Glacial Maximum: oxygen-isotope evidence. Mar. Micropaleontol., 32: 311-340.

Martinson, D.G.; Pisias, N.G.; Hays, J.D.; Imbrie, J.; Moore, T.C.; Shackleton, N.J. 1987. Age Dating e the Orbital Theory of the Ice Ages: Development of a High-Resolution 0 to 300,000-Year Chronostratigraphy. Quat. Res., 27: 1-29.

Maslin, M.A.; Shackleton, N.J.; Pflaumann, U. 1995. Surface water temperature, salinity and density changes in the northeast Atlantic during the last 45.000 years: Heinrich events, deep water formation and climatic rebounds. Paleoceanography, 10: 527-544.

Matano, R.P.; Schlax, M.G.; Chelton, D.B. 1993. Seasonal variability in the southwestern Atlantic. J. Geophys. Res., 98(C10): 18027-18036.

Mayewski, P.A.; Rohling, E.E.; Stager, J.C.; Karlén, W.; Maasch, K.A.; Meeker, L.D.; Meyerson, E.A.; Gasse, F.; van Kreveld, S.; Holmgren, K.; Lee-Thorp, J.; Rosqvist, G.; Rack, F.; Staubwasser, M.; Schneider, R.R.; Steig, E. 2004. Holocene climate variability. Quat. Res., 62: 243-255.

Mayle, F.E.; Beerling, D.J.; Gosling, W.D.; Bush, M.B. 2004. Responses of Amazonian ecosystems to climatic and atmospheric carbon dioxide changes since the last glacial maximum. Philos. Trans. R. Soc. Lond. A B, 359: 499-514.

McManus, J.F.; François, R.; Gherardi, J.-M.; Keigwin, L.D.; Brown-Leger, S. 2004. Collapse and rapid resumption of Atlantic meridional circulation linked to deglacial climate changes. Nature, 428: 834-837.

Melo, A.B.C.; Nobre, P.; Mendes, D.; Bottino, M.J. 2002. A Zona de Convergência Intertropical sobre o Oceano Atlântico: Climatologia. Anais do XII Congresso Brasileiro de Meteorologia, Sociedade Brasileira de Meteorologia, Foz do Iguaçu, PR, pp.682-686.

Meredith, M. P.; Grose, K. E.; McDonagh, E. L.; Heywood, K. J.; Frew, R. D.; Dennis, P. F. 1999. Distribution of oxygen isotopes in the water masses of Drake Passage and the South Atlantic. J. Geophys. Res., 104(C9): 20949-20962.

Metzler, P.M.; Glibert, P.M.; Gaeta, S.A.; Ludlam, J.M., 1997. New and regenerated production in the South Atlantic off Brazil. Deep-Sea Res.I, 44(3): 363-384.

Milliman, J.D. 1978. Morphology and structure of upper continental margin off southern Brazil. The American Association of Petroleum Geologists Bulletin, 62(6): 1029-1048. 
Mix, A.C.; Bard, E.; Schneider, R. 2001. Environmental processes of the ice age: land, oceans, glaciers (EPILOG). Quat. Sci. Rev., 20: 627-657.

Molfino, B.; McIntyre, A. 1990. Nutricline variation in the equatorial Atlantic coincident with the Younger Dryas. Paleoceanography, 5(6): 997-1008.

Mollenhauer, G.; Eglinton, T.I.; Ohkouchi, N.; Schneider, R.R.; Muller, P.J.; Grootes, P.M. 2003. Asynchronous alkenone and foraminifera records from the Benguela upwelling system. Geochim. Cosmochim. Acta, 67: 2157-2171.

Monnin, E.; Indermühle, A., Dällenbach, A., Flückiger, J., Stauffer, B., Stocker, T.F., Raynaud, D., Barnola, J.-M. 2001. Atmospheric $\mathrm{CO}_{2}$ concentrations over the Last Glacial Termination. Science 291, 112- 114.

Morgan, V.; Delmotte, M.; van Ommen, T.; Jouzel, J.; Chappellaz, J.; Woon, S.; MassonDelmotte, V.; Raynaud, D. 2001. Relative timing of deglacial climate events in Antarctica and Greenland. Science, 297: 1862-1864.

Moy, C.M.; Seltzer, G.O.; Rodbell, D.T.; Anderson, D.M. 2002. Variability of El Niño/Southern Oscillation acitivity at millennial timescales during the Holocene epoch. Nature, 420: 162-165.

Mulitza, S.; Dürkoop, A.; Hale, W.; Wefer, G.; Niebler, H.S. 1997. Planktonic Foraminifera as Recorders of Past Surface-Water Stratification. Geology, 25(4):335-338.

Muller, T.J.; Ikeda, Y.; Zangenberg, N.; Nonato, L.V. 1998. Direct measurements of western boundary currents off Brazil between $20^{\circ} \mathrm{S}$ and $28^{\circ} \mathrm{S}$. J. Geophys. Res., 103 (C3): 5429-5437.

Naidu, P.D.; Malmgren, B.A. 1996. Relationship between late Quaternary upwelling history and coiling properties of Neogloboquadrina pachyderma and Globigerina bulloides in the Arabian Sea. J. Foram. Res., 26(1):64-70.

Niebler, H. -S.; Arz, H.W.; Donner, S.; Mulitza, S.; Pätzold, J.; Wefer, G. 2003. Sea surface temperatures in the equatorial and South Atlantic Ocean during the Last Glacial Maximum (23-19ka). Paleoceanography, 18 (3): 1069.

Nobre, C.A.; Cavalcanti, I.F.A.; Gan, M.A.; Nobre, P.; Kayano, M.T.; Rao, V.B.; Bonatti, J.P.; Satyamurti, P.; Uvo, C.B.; Cohen,J.C. 1986. Aspectos da Climatologia Dinâmica do Brasil. Climanálise No. Especial, Boletim de Monitoramento e Análise Climática, 65 pp.

Nürnberg, D.; Bijma, J.; Hemleben, C. 1996. Assessing the reliability of Magnesium in foraminiferal calcite as a proxy for water mass temperatures. Geochim. Cosmochim. Acta, 60(5): 803-814.

Ohkouchi, N.; Eglinton, T.I.; Keigwin, L.D.; Hayes, J.M. 2002. Spatial and temporal offsets between proxy records in a sediment drift. Science, 289: 1224-1227.

Ohkouchi, N.; Mollenhauer, G.; Eglinton, T.I. 2003. Comparison of radiocarbon ages of alkenones with planktonic foraminifera and total organic carbon in oceanic surface sediments. Am. Geophys. Union, Fall Meeting 2003 abstract \#PP52C-04.

Oppo, D.W., Horowitz, M. 2000. Glacial deep water geometry: South Atlantic benthic foraminiferal $\mathrm{Cd} / \mathrm{Ca}$ and $\delta^{13} \mathrm{C}$ evidence. Paleoceanography, 15(2): 147-160. 
Oppo, D.W.; McManus, J.F.; Cullen, J.L. 2003. Deepwater variability in the Holocene epoch. Nature, 422: 277-278.

Otto-Bliesner, B.L.; Hewitt, C.D.; Marchitto, T.M.,; Brady, E.; Abe-Ouchi, A.; Crucifix, M.; Murakami, S.; Weber, S.L. 2007. Last Glacial Maximum ocean thermohaline circulation: PMIP2 mode intercomparisons and data constraints. Geophysical reesarch Letters, 34: L12706, 6pp.

Ortiz, J.D.; Mix, A.C.; Collier, R.W. 1995. Environmental control of living symbiotic and asymbiotic foraminifera of the California Current. Paleoceanography, 10(6):987-1009.

Östlund, H. G.; Craig, H.; Broecker, W.S.; Spencer, D. 1987. GEOSECS Atlantic, Pacific and Indian Ocean expeditions: Shorebased data and graphics, vol. 7, Tech. rep., National Science Foundation, Washington, D.C.

Paduano, G.M.; Bush, M.B.; Baker, P.A.; Fritz, S.C.; Seltzer, G.O. 2003, A vegetation and fire history of Lake Titicaca since the Last Glacial Maximum. Palaeogeogr. Palaeoclimatol. Palaeoecol., 194: 259-279.

Paegle, J.N.; Mechoso, C.R.; Fu, R.; Berbery, E.H.; Chao, W.C.; Chen, T.C.; Cook, K.; Diaz, A.F.; Enfield, D.; Ferreira, R.; Grimm, A.M.; Kousky, V.; Liebmann, B.; Marengo, J.; Mo, K.; Neelin, J.D.; Paegle, J.; Robertson, A.W.; Seth, A.; Vera, C.S.; Zhou, J. 2002. Progress in Pan American Clivar research: Understanding the South American Monsoon. Meteorologica, 27: 3-32.

Paegle, J.N.; Mo, K.C. 2002. Linkages between summer rainfall variability over South America and sea surface temperature anomalies. J. Clim., 15(12): 1389-1407.

Paillard, D.; Labeyrie, L.; Yiou, P. 1996. Macintosh program performs time-series analysis, Eos Transactions AGU 77 (39) (1996), p. 379.

Peeters, F.J.C.; Acheson, R.; Brumer, G-J.A.; de Ruijter, W.P.M.; Schneider, R.R.; Ganssen, G.M.; Ufkes, E.; Kroon, D. 2004. Vigorous exchange between the Indian and Atlantic oceans at the end of the past five glacial periods. Nature, 430: 661-665.

Peltier, W.R.; Fairbanks, R.G. 2006. Global glacial ice volume and Last Glacial Maxmimum duration from an extended Barbados sea level record. Quat. Sci. Rev., 24 (23-24): 3322-3337.

Pessenda, L.C.R.; de Oliveira, P.E.; Molfatto, M.; de Medeiros, V.B.; Garcia, R.J.F.; Aravena, R.; Bendassoli, J.A.; Leite, A.Z.; Saad, A.R.; Etchebehere, M.L. 2009. The evolution of a tropical rainforest/grassland mosaic in southeastern Brazil since 28,000 ${ }^{14} \mathrm{C}$ yr BP based on carbon isotopes and pollen records. Quat. Res., 71 (3): 437-452.

Peterson, R.G.; Stramma, L. 1991. Upper-level circulation in the South Atlantic Ocean. Progr. Ocean., 26: 1-73.

Petit, J.R.; Jouzel, J.; Raynaud, D.; Barkov, N.I.; Barnola, J.-M.; Basile, I.; Benders, M.; Chappellaz, J.; Davis, M.; Delaygue, G.; Delmotte, M.; Kotlyakov, V.M.; Legrand, M.; Lipenkov, V.Y.; Pépin, L.; Ritz, C.; Saltzman, E.; Stievenard, M. 1999. Climate and atmospheric history of the past 420,000 years from the Vostok ice core, Antarctica. Nature, 399: 429-436. 
Pflaumann, U.; Duprat, J.; Pujol, C.; Labeyrie, L.D. 1996. SIMMAX: A Modern Analog Technique to Deduce Atlantic Sea Surface Temperatures from Planktonic Foraminifera in Deep-Sea Sediments. Paleoceanography, 11(1):15-35.

Pflaumann, U.; Sarnthein, M.; Chapman, M.; d’Abreu, L.; Funnell, B.; Huels, M.; Kiefer, T.; Maslin, M.; Schulz, H.; Swallow, J.; van Kreveld, S.; Vautravers, M.; Vogelsang, E.; Weinelt, M. 2003. Glacial North Atlantic: Sea-surface conditions reconstructed by GLAMAP 2000. Paleoceanography, 18 (3):1065, 28p.

Pickard, G.L.; Emery, W.J. 1990. Descriptive Physical Oceanography: An Introduction. Pergamon Press, Oxford, England, 320 pp.

Pierre, C.; Vergnaud-Grazzini, C.; Faugeres, J.-C. 1991. Oxygen and carbon stable isotope tracers of the water masses in the Central Brazil Basin. Deep Sea Res., 38: 597-606.

Pimenta, F.M.; Campos, E.J.D.; Miller, J.L.; Piola, A.R. 2005. A numerical study of the Plata River Plume along the Southeastern South American continental shelf. Braz. J. Oceanogr., 53(3/4): 129-146.

Pinot, S.; Ramstein, G.; Harrison, S.P.; Prentice, I.C.; Guiot, J.; Stute, M.; Joussaume, S. 1999. Tropical paleoclimates at the Last Glacial Maximum: comparison of Paleoclimate Modeling Intercomparison Project (PMIP) simulations and paleodata. Clim. Dyn., 15: 857-874.

Piola, A.R.; Matano, R.P.; Palma, E.D.; Möller Jr, O.O.; Campos, E.J.D. 2005. The influence of the Plata River discharge on the western South Atlantic shelf. Geophys. Res. Lett., 32 (L01603).

Piola, A.R.; Campos, E.J.D.; Möller Jr, O.O.; Charo, M.; Martinez, C. 2000. Subtropical shelf front off eastern South America. J. Geophys. Res., 195(C3): 6565-6578.

Portilho-Ramos, R.C.; Rios-Netto, A.M.; Barbosa, C.F. 2006. Caracterização bioestratigráfica do Neógeno superior da Bacia de Santos com base em foraminíferos planctônicos. Rev. Bras. Geoc., 9(3): 349-354.

Pozzi, M.; Malmgren, B.A.; Monechi, S. 2000. Sea surface water temperature and isotopic reconstructions from nannoplankton data using Artificial Neural Networks. Palaeontologia Electronica, 3(2): 4, 14pp.

Prahl, F.G.; Wakeham, S.G. 1987. Calibration of unsaturation patterns in long-chain ketone compositions for palaeotemperature assessment. Nature, 330: 367-369.

Prahl, F.G.; Wolfe, G.V.; Sparrow, M.A. 2003. Physiological impacts on alkenone paleothermometry. Paleoceanography, 18(2): 1025.

Prell, W.L.; Kutzbach, J.E. 1987. Monsoon variability over the past 150,000 Years. J. Geophys. Res., 92(D7): 8411-8425.

Prentice, C.; Jolly, D.; BIOME 6000 Participants 2000. Mid-Holocene and glacialmaximum vegetation geography of the northern continents and Africa. Journal of Biogeography, 27: 507-519.

Rahmstorf, S. 1995. Bifurcations of the Atlantic thermohaline circulation in response to changes in the hydrological cycle. Nature, 378: 145-149. 
Rahmstorf, S. 1996. On the freshwater forcing and transport of the Atlantic thermohaline circulation. Clim. Dyn., 12: 799-811.

Rahmstorf, S. 2002. Ocean circulation and climate during the past 120,000 years. Nature, 419: $207-214$.

Rahmstorf, S. 2003. The current climate. Nature 421,13: 699.

Rahmstorf, S. 2006. Thermohaline ocean circulation. In: Encyclopedia of Quaternary Sciences, Elias, S.A. (Ed.). Elsevier, Amsterdam.

Ravelo, A. C.; Andreasen, D.H. 1999. Using planktonic foraminifera as monitors of the tropical surface ocean. In: Abrantes, F. e Mix, A. (Eds.) Reconstructing Ocean History A window into the future. Plenum Press, New York, pp. 217-244.

Ravelo, A.C.; Fairbanks, R.G.; Philander, S.G.H. 1990. Reconstructing Tropical Atlantic Hydrography Using Planktonic Foraminifera and an Ocean Model. Paleoceanography, 5(3): 409-431.

Renaud, S.; Schmidt, D.N. 2003. Habitat tracking as a response of the planktonic foraminifer Globorotalia truncatulinoides to environmental fluctuations during the last 140 kyr. Mar. Micropaleontol., 49: 97-122.

Renssen, H.; Goosse, H.; Fichefet, T. 2002. Modeling the Effect of Freshwater Pulses on Early Holocene Climate: The Influence of High-Frequency Climate Variability. Paleoceanography, 17(2): 1020.

Renssen, H.; Van Geel, B.; Van der Plicht, J.; Magny, M. 2001. Reduced solar activity as a trigger for the start of the Younger Dryas. Quat. Int., 68-71:373-383.

Rind, D.; Peteet, D. 1985. Terrestrial conditions at the Last Glacial Maximum and CLIMAP sea-surface temperature estimates: are they consistent? Quat. Res., 24: 1-22.

Robbins, L.L.; Coble, P.G.; Clayton, T.D.; Cai, W.-J. 2009. Ocean carbon and biogeochemistry scoping Workshop on terrestrial and coastal carbon fluxes in the Gulf of Mexico, St. Petersburg, FL, May 6-8, 2008. U.S. Geol. Survey Open-File Report 2009-1070, 46 pp.

Roberts, N. 1998. The Holocene. An Environmental History. 2 $2^{\text {nd }}$ Edition. Blackwell Publishing, Hong Kong, 316pp.

Robertson, A.W.; Mechoso, C.R. 2000. Interannual and interdecadal variability of the South Atlantic Convergence Zone. Mon. Weather Rev., 128: 2947-2957.

Rodrigues, M.L.G.; Franco, D.; Shigetoshi, S. 2004. Climatologia de frentes frias no litoral de Santa Catarina. Rev. Bras. Geofís., 22(2): 135-151.

Rodrigues, R.R.; Rothstein, L.M.; Wimbush, M. 2006. Seasonal variability of the South Equatorial Current bifurcation in the Atlantic Ocean: A numerical study. J. Phys. Ocean., 37: 16-30.

Rohling, E.J.; Bigg, G.R. 1998. Paleosalinity and $\delta^{18}$ O: A Critical Assessment. J. Geophys. Res, 103(C1):1307-1318.

Rohling, E.J.; Cooke, S. 1999. Stable oxygen and carbon isotopes in foraminiferal carbonate shells. In: Modern Foraminífera, Sen Gupta, B.K. (Ed.). Kluwer Academic Publishers, Dordrecht, The Netherlands, pp. 239-258. 
Rohling, E.J.; Mayewski, P.A.; Abu-Zeid, R.H.; Casford, J.S.L.; Hayes, A. 2002. Holocene atmosphere-ocean interactions: records from Greenland and the Aegean sea. Clim. Dyn., 18: 587-593.

Rostek, F.; Ruhland, G.; Bassinot, F.C.; Müller, P.J.; Labeyrie, L.D.; Lancelot, Y.; Bard, E. 1993. Reconstructing sea surface temperature and salinity using $\delta^{18} \mathrm{O}$ and alkenone records. Nature, 364: 319-321.

Rowe. H.D., Guilderson, T.P., Dunbar, R.B., Southon, J.R., Seltzer, G.O., Mucciarone, D.A., Fritz, S.C., and Baker, P.A. 2003, Late Quaternary lake-level changes constrained by radiocarbon and stable isotope studies on sediment cores from Lake Titicaca, South America. Global Planet. Change, 38: 273-290.

Ruddiman, W.F. 1977. Investigations of Quaternary climate based on planktonic foraminifera. In: Oceanic Micropaleontology, Ramsay, A.T.S. (Ed.), New York, Academic Press, pp.101-161.

Ruddiman, W.F. 2003. The anthropogenic greenhouse era began thousands of years ago. Clim. Change, 61: 261-293.

Ruddiman, W.F. 2005. Plows, Plagues \& Petroleum. How humans took control of climate. Princeton Univ. Press, Princeton, New Jersey. 202 pp.

Rühlemann, C.; Mulitza, S.; Müller, P.J.; Wefer, G.; Zahn, R. 1999. Warming of the Tropical Atlantic Ocean and Slowdown of Thermohaline Circulation During the Last Deglaciation. Nature, 402: 511-514.

Ruiz-Barradas, A.; Carton, J.A.; Nigam, S. 2000. Structure of interannual-to-decadal climate variability in the tropical Atlantic sector. J. Clim., 13: 3285- 3297.

Sarnthein, M.; Gebhardt, H.; Kiefer, T.; Kucera, M.; Cook, M.; Erlenkeuser, H. 2004. Mid Holocene origin of the sea-surface salinity low in the subarctic North Pacific. Quat. Sci. Rev., 23: 2089-2099.

Sarnthein, M.; Gersonde, R.; Niebler, S.; Pflaumann, U.; Spielhagen, R.; Thiede, J.; Wefer, G.; Weinelt, M. 2003. Overview of Glacial Atlantic Ocean Mapping (GLAMAP 2000). Paleoceanography, 18(2): 1030.

Sarnthein, M.; Winn, K.; Jung, S. J. A.; Duplessy, J.-C.; Labeyrie, L.; Erlenkeuser, H.; Ganssen, G. 1994. Changes in East Atlantic Deepwater Circulation Over the Last 30,000 years: Eight Time Slice Reconstructions. Paleoceanography, 9(2): 209-267

Satyamurty, P., Mattos, L.F.; Nobre, C.A.; Silva Dias, P.L. 1998. Tropics - South America. In: Meteorology of the Southern Hemisphere, Kauly, D. J.; Vincent, D. G. (Eds.). Meteorol. Monograph. Am. Meteorol. Soc., Boston, 119-139.

Sautter, L.R.; Thunell, R.C. 1991. Planktonic foraminiferal response to upwelling and seasonal hydrographic conditions: sediment trap results from San Pedro Basin, Southern California Bight. J. Foram. Res., 21(4):347-363.

Schäfer-Neth, C. 1998. Changes in the Seawater Salinity- Oxygen Isotope Relation between Last Glacial and Present: Sediment Core Data and OGCM Modelling. Paleoclimates, 2(2-3): 101-131. 
Schmidt, G.A. 1999. Error analysis of paleosalinity reconstructions. Paleoceanography, 14(3): 422- 429.

Schmidt, G.A.; Mulitza, S. 2002. Global calibration of ecological models for planktic foraminifera from coretop carbonate oxygen-18. Mar. Micropaleontol., 44: 125-140.

Schmidt, D.N.; Renaud, S.; Bollmann, J. 2003a. Response of planktic foraminiferal size to Late Quaternary climate change. Paleoceanography, 18(2): 1039.

Schmidt, D.N.; Renaud, S.; Bollmann, J.; Schiebel, R.; Thiersten, H.R., 2003b. Size distribution of Holocene planktic foraminifer assemblages: biogeography, ecology and adaptation. Mar. Micropaleontol., 956: 1-20.

Seidov, D.; Haupt, B.J. 2002. On the role of inter-basin surface salinity contrasts in global ocean circulation. Geophys. Res. Lett., 29(16): 10.1029.

Seidov, D.; Haupt, B.J. 2003. Freshwater teleconnections and ocean thermohaline circulation. Geophys. Res. Lett., 30 (6): 62-1 - 62-4.

Shackleton, N.J. 1977. Carbon-13 in Uvigerina: Tropical rainforest history and the equatorial Pacific carbonate dissolution cycles. In: The Fate of Fossil Fuel $\mathrm{CO}_{2}$, Andersen, N.R. e Malahoff, A., (Eds.), Plenum Publishers, New York, pp. 401-427.

Shackleton, N.J. 1982. The deep-sea sediment record of climate variability. Progr. Ocean., 11: 199-218.

Silveira, I.C.A.; Schmidt, A.C.K.; Campos, E.J.D.; Godoi, S.S.; Ikeda, Y. 2000. A Corrente do Brasil ao largo da costa Leste Brasileira. Rev. Bras. Oceanogr., 48(2): 171-183.

Singer, C.; Shulmeister, J.; McLea, B. 1998. Evidence against a significant Younger Dryas cooling event in New Zealand. Science, 281: 812-814.

Smith, W. H. F.; Sandwell, D. T. 1997. Global seafloor topography from satellite altimetry and ship depth soundings. Science, 277: 1957-1962.

Sorano, M.R.G.S., 2006. Distribuição de foraminíferos planctônicos (0-100m na coluna d'água) e seu registro no sedimento na Margem Continental Sudeste Brasileira, entre São Sebastião, SP, e Cabo de São Tomé, RJ. Diss. Mestrado. Instituto Oceanográfico, Univ. de São Paulo. 104 pp.

Souza, E.B.; Nobre, P. 1998. Uma revisão sobre o padrão de Dipolo no Atlântico Tropical. Rev. Bras. Meteorol., 13(1): 31-44.

Spero, H.J.; Bijma, J.; Lea, D.W.; Russell, A.D. 1999. Deconvolving glacial ocean carbonate chemistry from the planktonic foraminifera carbon isotope record. In: Reconstructing Ocean History: A window into the future, Abrantes, F. e Mix, A., (Eds.), Plenum Publishers, New York, pp. 329-342.

Stanford, J.D.; Rohling, EJ.; Hunter, S.E.; Roberts, A.P.; Rasmussen, S.O.; Bard, E.; McManus, J.; Fairbanks, R.G. 2006. Timing of meltwater pulse 1a and climate responses to meltwater injections. Paleoceanography, 21: PA4103, 9pp.

Stocker, T.F.; Marchal, O. 2000. Abrupt Climate Change in the Computer: Is it Real? Proc. Nat. Acad. Sci., 97(4): 1362-1365.

Stramma, L. 1989. The Brazil Current transport south of $23^{\circ}$ S. Deep-Sea Res., 36: 639-646. 
Stramma, L.; Ikeda, Y.; Peterson, R.G. 1990. Geostrophic transport in the Brazil Current region north of $20^{\circ}$ S. Deep-Sea Res., 37(12): 1875-1886.

Stramma, L.; Schott, F. 1999. The mean flow of the tropical Atlantic Ocean. Deep-Sea Res. II, 46: 279-303.

Stute, M.; Forster, M.; Frischkorn, H.; Serejo, A.; Clark, J.F.; Schlosser, P.; Broecker, W.S.; Bonanai, G. 1995. Cooling of tropical Brazil $\left(5^{\circ} \mathrm{C}\right)$ during the Last Glacial Maximum. Science, 269: 379-383.

Tapia, P.M., Fritz, S., Baker, P.A., Seltzer, G.O.; Dunbar, R.B. 2003. A Late Quaternary diatom record of tropical climatic history from Lake Titicaca (Peru and Bolivia). Palaeogeogr. Palaeoclimatol. Palaeoecol., 194: 139-164.

Tolderlund, D.; Bé, A.W.H. 1971. Seasonal distribution of planktonic foraminifera in the Western North Atlantic. Micropaleontology, 17(3): 297-329.

Toledo, F.A.L. 2000. Variações paleoceanográficas nos últimos 30.000 anos no Oeste do Atlântico Sul: isótopos de oxigênio, assembléias de foraminíferos planctônicos e nanofósseis calcários. Tese de Doutorado, Instituto de Geociências, Univ. Federal do Rio Grande do Sul, 250 pp.

Toledo, F.A.L.; Cachão, M.; Costa, K.B.; Pivel, M.A.G. 2007a. Planktonic foraminífera, calcareous nannoplankton and ascidian variations during the last $25 \mathrm{kyr}$ in the Southwestern Atlantic: A paleoproductivity signature? Mar. Micropaleontol., 64: 67-79.

Toledo, F.A.L.; Costa, K.B.; Pivel, M.A.G. 2007b. Salinity changes in the western tropical South Atlantic during the last 30 kyr. Global. Planet. Change, 57: 383-395.

Toledo, F.A.L.; Costa, K.B.; Pivel, M.A.G, Campos, E. J.D. 2008. Tracing past circulation changes in the western South Atlantic based on planktonic foraminifera. Rev. Bras. Paleontol., 11(3): 169-178.

Tomczak, M.; Godfrey, J.S. 2001. Regional Oceanography: An Introduction. $2^{\text {nd }}$ Ed. Daya Publishing House, Dehli. 390pp.

Tudhope, A.W.; Chilcott, C.P.; McCulloch, M.T.; Cook, E.R.; Chappell, J.; Ellam, R.M.; Lea, D.W.; Lough, J.M.; Shimmield, G.B. 2001. Variability in the El Niño-Southern Oscillation through a glacial-interglacial cycle. Science, 291: 1511-1517.

Valdes, P.J.; Glover, R.W. 1999. Modelling the climate response to orbital forcing. Philos. Trans. R. Soc. Lond. A, 357: 1873-1890.

van der Zwaan, G.J.; Duijnstee, I.A. P.; den Dulk, M.; Ernst, S.R.; Jannink, N.T.; Kouwenhoven, T.J. 1999. Benthic foraminifers: proxies or problems? A review of paleocological concepts. Earth-Sci. Rev., 46: 213-236.

van Hinsbergen, D.J.J.; Kouwenhoven, T.J.; can der Zwaan, G.J. 2005. Paleobathymetry in the backstripping procedure: Correction for oxygenation effects on depth estimates. Palaeogeogr. Palaeoclimatol. Palaeoecol., 221: 245-265.

Venegas, S.A. 1995. Interannual variability of the sea surface temperature and the overlying atmospheric circulation in the western South Atlantic. MSc Thesis. Dpt of Atmospheric and Oceanic Sciences, McGill University, Montreal, Canada. 85 pp. 
Vera, C.; Higgins, W.; Amador, J.; Ambrizzi, T.; Garreaud, R.; Gochis, D.; Gutzler, D.; Lettenmaier, D.; Marengo, J.; Mechoso, C.R.; Nogués-Paegle, J.; Silva Dias, P.L.; Zhang, C. 2006. Toward a unified view of the American Monsoon Systems. J. Clim., 19: 4977-5000.

Vicalvi, M. A. 1997. Zoneamento bioestratigráfico e paleoclimático dos sedimentos do Quaternário superior do talude da Bacia de Campos, RJ, Brasil. Bol. Geoc. Petrobras, $11(1 / 2): 132-165$.

Vidal, L.; Schneider, R.R.; Marchal, O.; Bickert, T.; Stocker, T.F.; Wefer, G. 1999. Link between the North and South Atlantic during the Heinrich Events of the Last Glacial period. Clim. Dyn., 15: 909-919.

Violante, R.A.; Parker, G. 2004. The post-glacial maximum transgression in the de la Plata River and adjacent inner continental shelf, Argentina. Quat. Int., 114: 167-181.

Vuille, M., Werner, M. 2005. Stable isotopes in precipitation recording South American summer monsoon and ENSO variability: observations and model results. Clim. Dyn., $25,401-413$.

Wadley. M.R.; Bigg, G.R.; Rohling, E.J.; Payne, A.J. 2002. On modelling present-day and last glacial maximum oceanic $\delta^{18} \mathrm{O}$ distributions. Global Planet. Change, 32: 89-109.

Wang, L.; Pflaumann, U.; Sarnthein, M. 1995. Paleo sea surface salinities in low latitude Atlantic: The $\delta^{18} \mathrm{O}$ record of Globigerinoides ruber (white). Paleoceanography, 10(4): 749-761.

Wanner, H.; Beer, J.; Bütikofer, J.; Crowley, T.J.; Cubasch, U.; Flückiger, J.; Goosse, H.; Grosjean, M.; Joos, F.; Kaplan, J.O.; Küttel, M.; Müller, S.A.; Prentice, I.C.; Solomina, O.; Stocker, T.F.; Tarasov, P.; Wagner, M.; Widmann, M. 2008. Mid-to Late Holocene climate change: an overview. Quat. Sci. Rev., 27: 1791-1828.

Watkins, J.M.; Mix, A.C.; Wilson, J. 1998. Living planktonic foraminifera in the central tropical Pacific Ocean: articulating the equatorial 'cold tongue' during La Niña, 1992. Mar. Micropaleontol., 33: 157-174.

Weaver, A.J.; Saenko, O.A.; Clark, P.U.; Mitrovica, J.X. 2003. Meltwater Pulse 1A from Antarctica as a trigger of the Bølling- Allerød warm interval. Science, 299: 1709-1713.

Wefer, G.; Berger, W.H.; Bijma, J.; Fischer, G. 1999. Clues to ocean history: A brief overview of proxies. In: Fischer, G.; Wefer, G., (Eds.) Use of Proxies in Paleoceanography: Examples from the South Atlantic. Springer-Verlag, Berlin Heidelberg, pp. 1-68.

Weijer, W.; de Ruijter, W.P.M.; Sterl, A.; Drijfhout, S.S. 2002. Response of the Atlantic overturning circulation to South Atlantic sources of buoyancy. Global Planet. Change, 34: 293-311.

Weinelt, M.; Vogelsang, E.; Kucera, M.; Pflaumann, U.; Sarnthein, M.; Voelker, A.; Erlenkeuser, H.; Malmgren, B.A. 2003. Variability of North Atlantic heat transfer during MIS 2. Paleoceanography, 18 (3): 1071, 18p. 
Weldeab, S.; Schneider, R.R.; Kölling, M. 2006. Deglacial sea surface temperature and salinity increase in the western tropical Atlantic in synchrony with high latitude climate instabilities. Earth Planet. Sci. Lett., 241: 699-706.

Wirrmann, D.and Mourguiart, P. 1995. Late Quaternary spatio-temporal limnological variations in the Altiplano of Bolivia and Peru. Quat. Res., 43, 344-354.

Wunsch, C. 2002. What is the Thermohaline Circulation? Science, 298: 1179-1180.

Wunsch, C. 2003. Determining paleoceanographic circulations, with emphasis on the Last Glacial Maximum. Quat. Sci. Rev., 22: 371-385.

Yu, E.-F.; François, R.; Bacon, M.P. 1996. Similar rates of modern and last-glacial ocean thermohaline circulation inferred from radiochemical data. Nature, 379: 689-694.

Zebiak, S.E. 1993. Air-sea interaction in the equatorial Atlantic region. J. Clim., 6: 15671586.

Zembruscki, S.G. 1979. Geomorfologia da Margem Continental Sul Brasileira e das Bacias Oceânicas Adjacentes. In: Geomorfologia da Margem Continental Brasileira e Das Áreas Oceânicas Adjacentes, Série Projeto REMAC, No. 7, pp. 129-177. CENPES/PETROBRÁS, Rio de Janeiro.

Zhou, J.; Lau, K.-M. 1998. Does a monsoon climate exist over South America? J. Clim., 11: 1020-1040. 
ANEXOS 


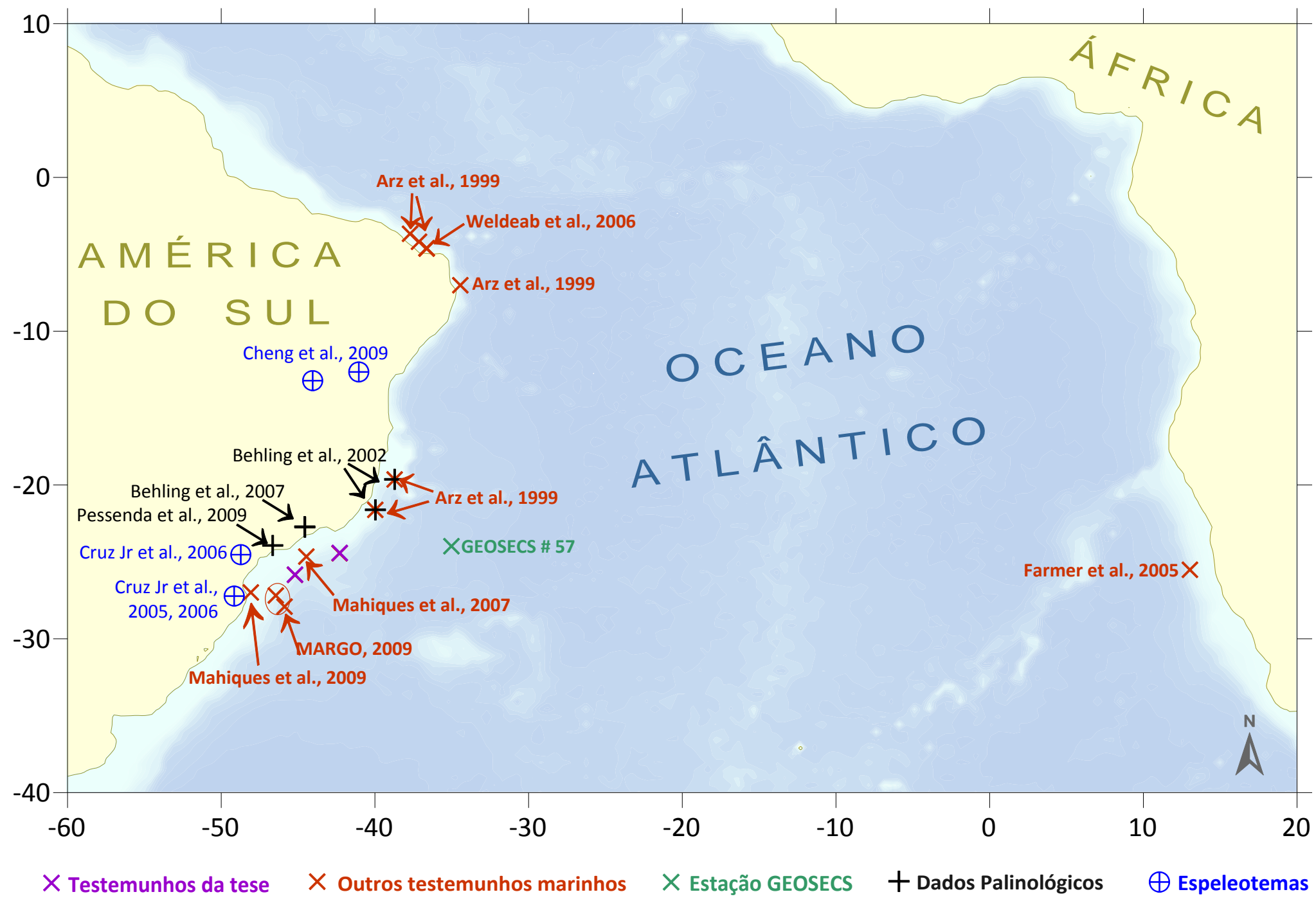

Fig. A1. Localização de diferentes registros mencionados ao longo da discussão. 


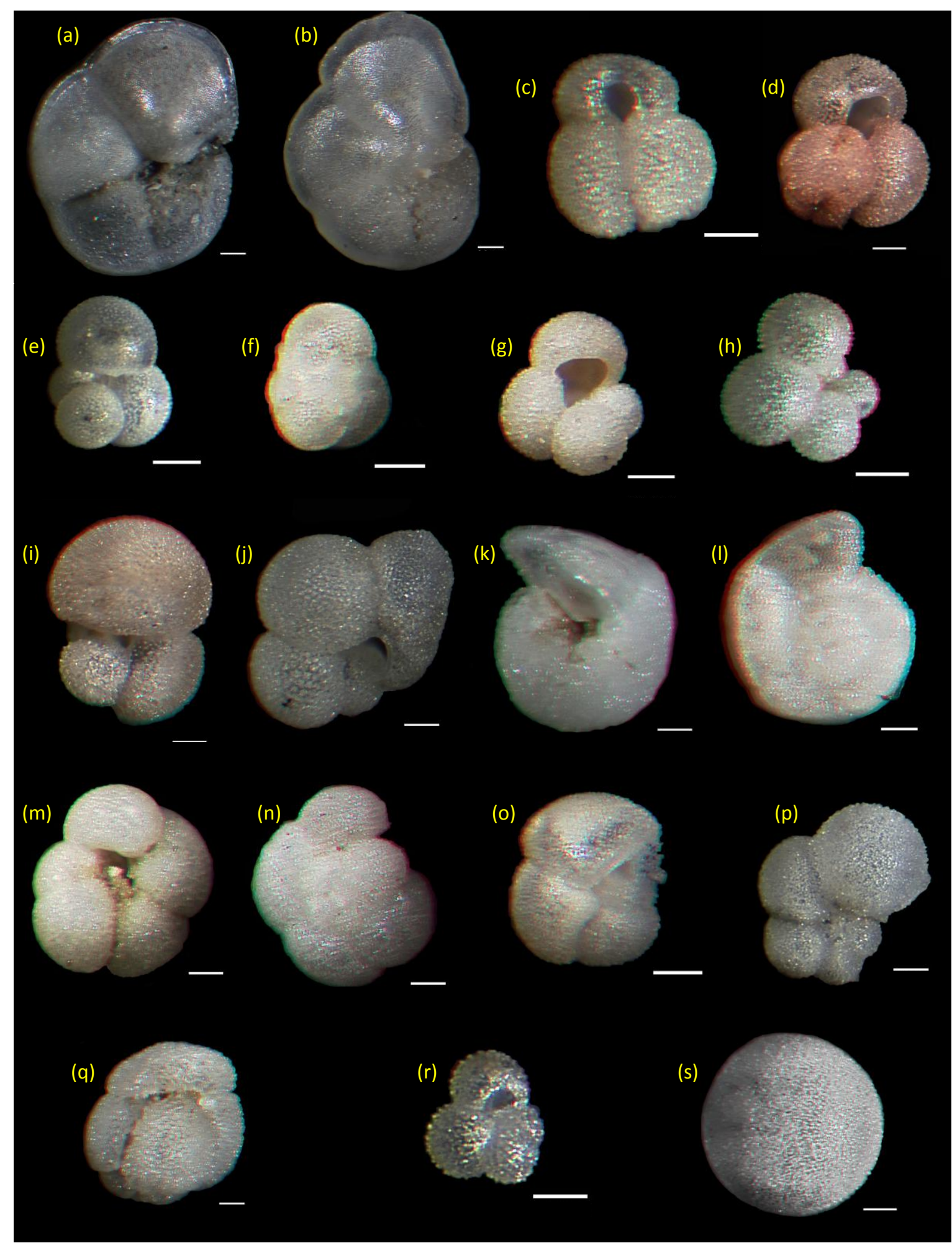

Fig. A2. Fotografias em visão estereoscópica de exemplares de diferentes espécies de foraminíferos planctônicos identificadas no trabalho: (a) G. menardii, (b) G. tumida, (c) $G$. ruber (white), (d) G. ruber (pink), (e) G. glutinata, (f) G. glutinata com bulla (g) G. bulloides, (h) G. calida, (i) G. sacculifer, (j) G. sacculifer com saco, (k) e (1) G. truncatulinoides, (m) e (n) N. dutertrei, (o) G. inflata, (p) G. siphonifera, (q) G. conglobatus, (r) G. tenella, (s) O. universa. Escala $=0,1 \mathrm{~mm}$. Os óculos necessários para a visualização tridimensional encontram-se dentro do envelope no lado interno da contracapa. 